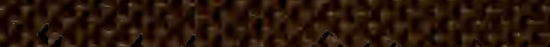

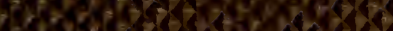

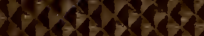

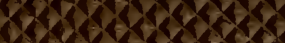

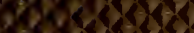

1008?

त)

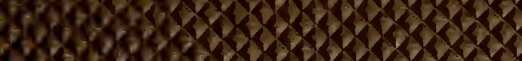

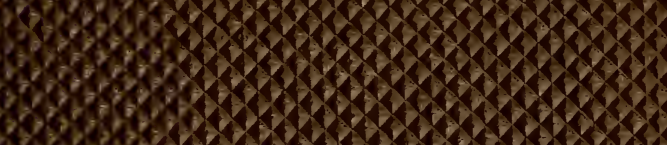

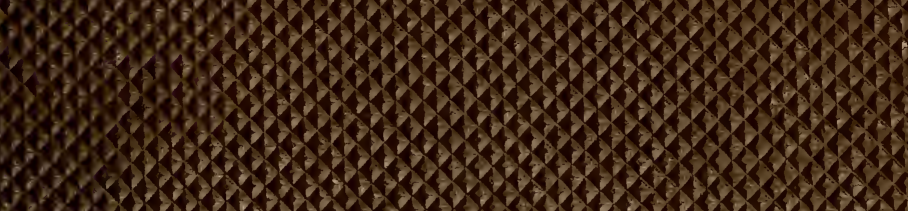

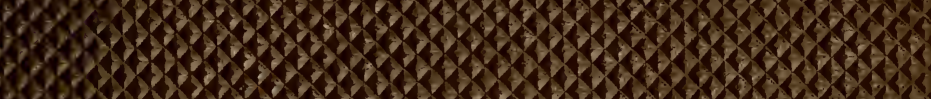

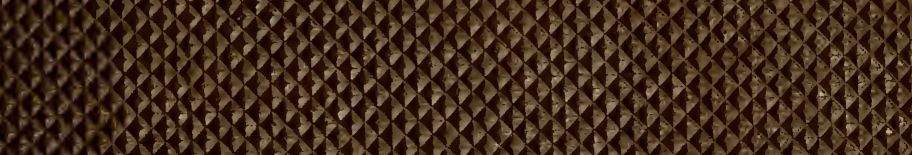

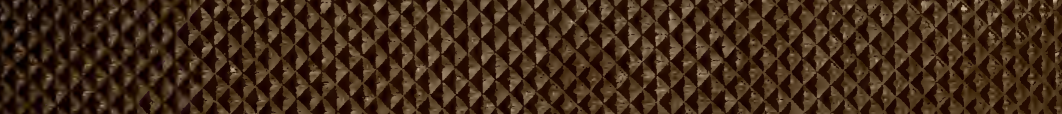

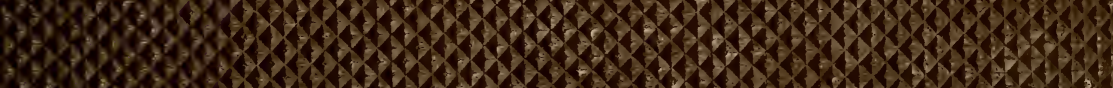

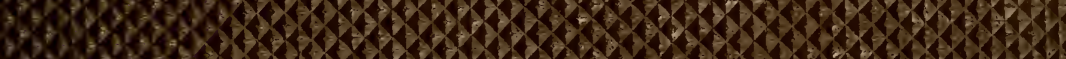

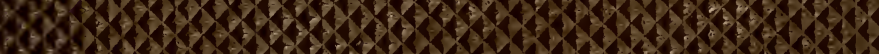

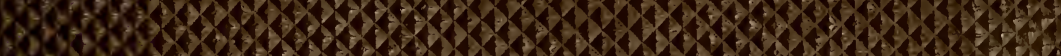

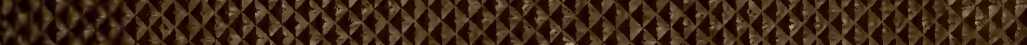

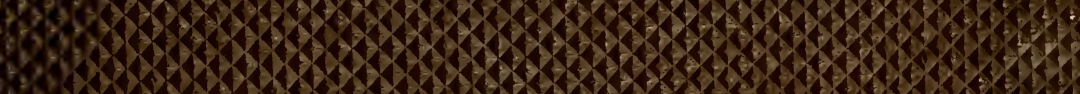

1.

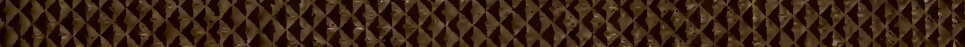

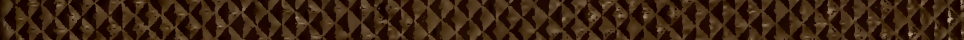

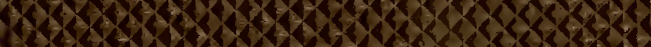

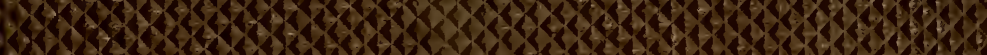

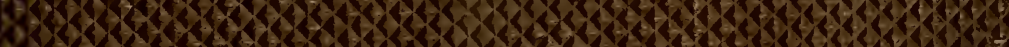

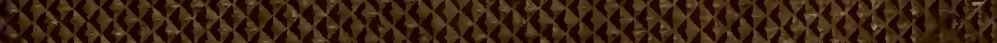

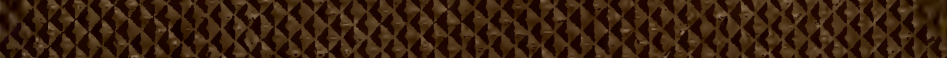

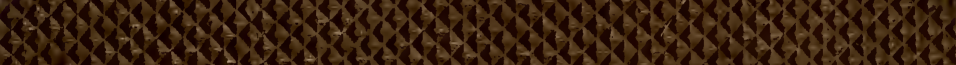




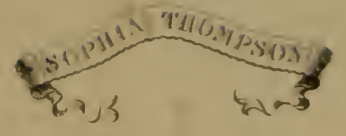

THE UNIVERSITY

$$
\text { OF ILLINOIS }
$$

\section{LIBRARY}

$$
595.79
$$$$
\text { K63m }
$$

v. 2 . 




\section{MONOGRAPHIA \\ $A \mathbb{P} \mathbb{U} \mathbb{M} \quad A \mathbb{N} \mathbb{L} I \mathbb{E}$.}

IN TWO VOLUMES.

VOL. II. 
I

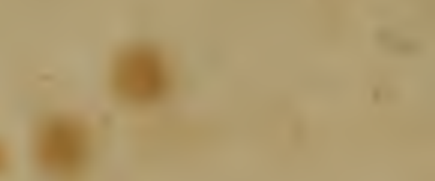

15 (n)

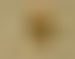

a

(n)

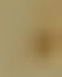

$+$
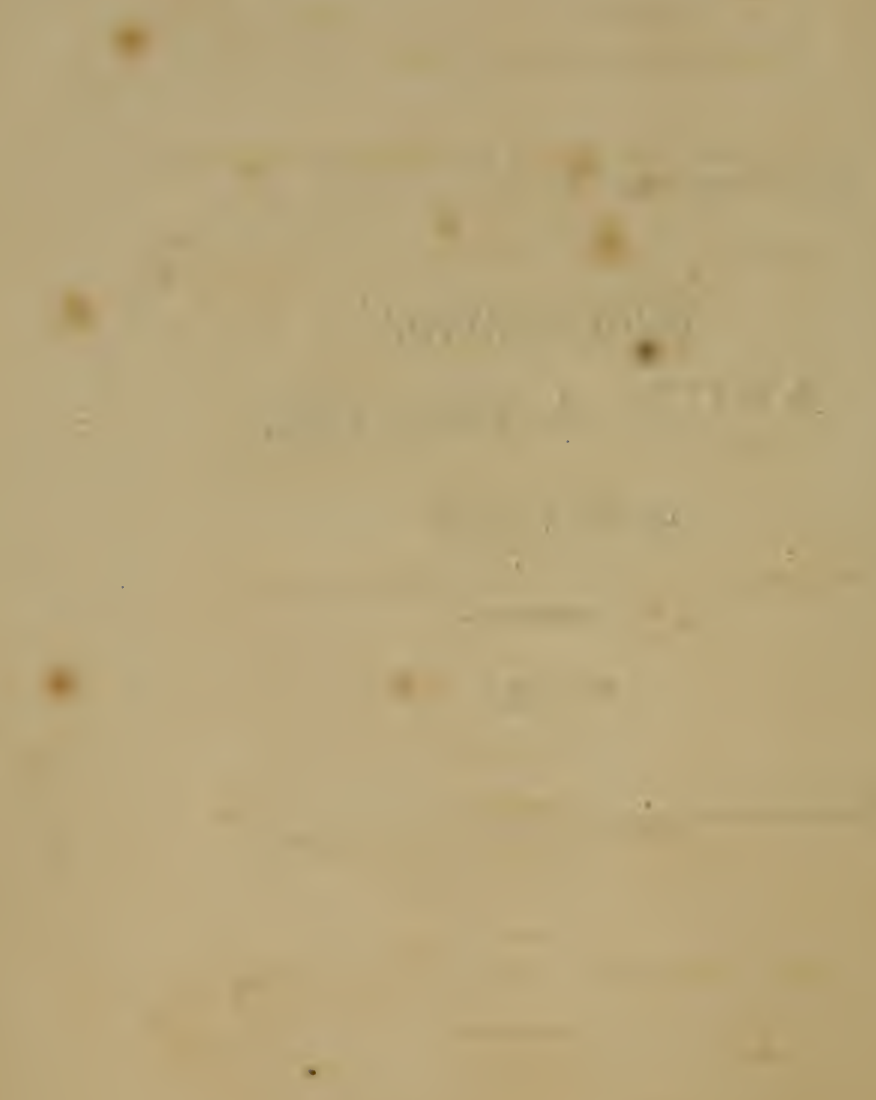


\section{MONOGRAPHIA}

\section{$A \mathbb{P} \mathbb{U} \mathbb{M} \mathbb{N} \mathbb{L} \mathbb{I} \mathbb{E}$;}

OR,

AN ATTEMPT TO DIVIDE INTO THEIR

NATURAL GENERA AND FAMILIES,

SUCH

SPECIES OF THE LINNEAN GENUS

$$
\text { A } \mathbb{P} I \mathbb{S}
$$

AS HAVE BEEN DISCOVERED IN ENGLAND:

wITH

Descriptions and Observations.

To which are prefixed

SOME INTRODUCTORY REMARKS UPON THE CLASS

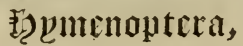

A Synoptical TABLE of the Nomenclature of the external Parts of these Insects.

WITH PLATES.

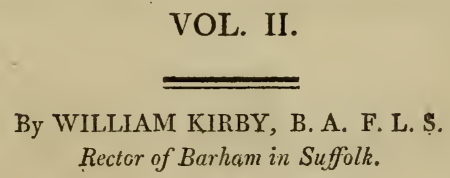

VOL. II.

Printed for the Author ly J. Raw, AND SOLD BY J. WHITE, FLEET-STREET, LONDON.

1802. 


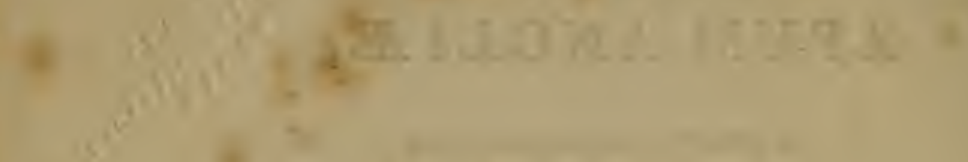
$+5$

ra

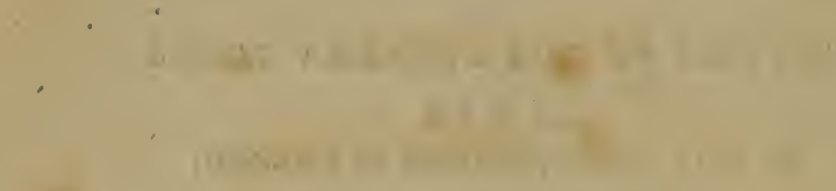

$+$
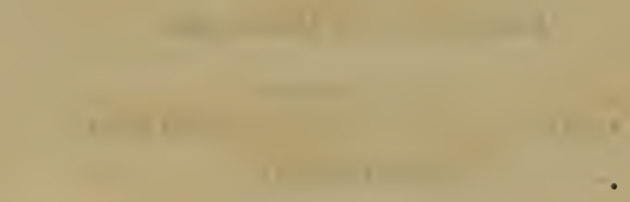

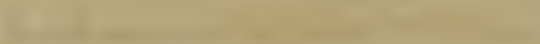

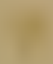

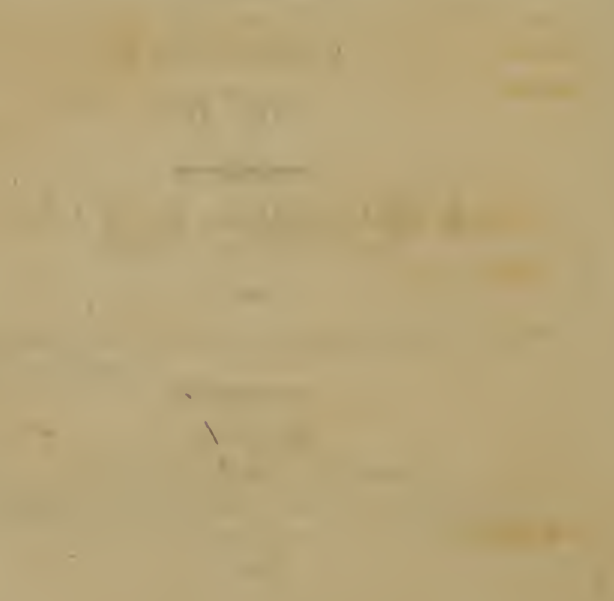


MONOGRAPHIA

$A \mathbb{P} U \mathbb{M}$ I ANGIIZE.

PARS TERTIA.

SPECIERUM $f$. NOMINUM SPECIFICORUM SYNOPSIN EXHIBENS.

Multa fecisti tu JeHova Deus meus, mirabilia tua : et co. gitationes tuas erga nos, nemo est qui ordinare possit tibi : si enuntiare et eloqui velim, plura sunt quàm ut narrentur.

Ps. xl. 5.

Reddere personæ scit convenientia cuique. Hor!

ทัน. II.

A 


\section{SYNOPSIS SPECIERUM.}

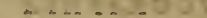

c I. MELITTA. (a)

$O^{S}$ proboscide subcylindricâ, porrectâ, linguam brevem, planiusculam, exerente.

Antennce mediæ, aculeatis subclavatæ articulis

13; maribus filiformes articulis $1 A$.

Oculi Iateraies, subovales, integri.

Alae planæ.

Aculeus punctorius, reconditus.

$$
\text { *. a. }
$$

Os linguâ apice bilobâ; valvulis plicatis.

Lalium anticè obtusangulum.

Corpus villosum.

succincta.1. M. nigra, albido-villosa; thorace fulvo; abdomine ovato; seginentis margine albis. (1)

$\checkmark$ fodiens. 2. M. nigra, albido-villosa; thorace fulvescenti; abdomine conico, basi subretuso; segmentis margine pallidis. (2)

$$
\text { *. b. }
$$

Os linguâ subtruncatâ, aưriculatâ.

Latium anticè obtusangulum.

(a) Tab. 1-4. 
SYNOPSIS SPECIERUM. (Melitta.)

Abdomen conicum, supra gibbum.

Corpus glabrum.

Obs. Antenna feminece apice recurva.

3. M. atra; fronte maculatâ ; tibiís posticis albido annulata. annulatis. (1)

4. M. atra; fronte maculatâ ; tibiis omnibus flavo annularis. annulatis. (2)

5. M. atra; tibiis flavis, nigro annulatis; antennis dilatata. scapo patelliformi. (3)

6. M. atra; fronte maculatâ; abdomine segmento signata. primo margine utrinque albo. (4)

$$
\text { **. a. }
$$

Os linguâ acutâ, auriculatât:

Labium inflexum, anticè emarginatum.

Abdomen ovatum, glabrum, supra gibbum.

Corpus subpilosum.

Obs. Antenna feminece apice recurva. Aldomen masculum lineare; antenna submonitiformes.

v 7. M. atra; abdomine ferrugineo, apice nigro. (1) gibla,

8. M. atra; abdomine rufo, apice, pedibusque, Geofrel: nigro-piceis; maxillis, tarsis, tibiisque anticis, ${ }^{l a}$. rufescentibus. (2)

9. M. aterrima; abdomine ferrugineo, basi apice- Sphecoique nigro ; alis nigricantibus. (2)

10. M. atra; antennis piceis, thorace longioribus; monilicorabdomine cingulo rufo. (3)

11. M. atra, glabriuscula; abdomine piceo, nitido; picea.

A 2 segmentis 
segmentis intermediis basi et utrinque ferru. gineis. (5)

divisa. 12. M: atra; abdomine subovali, nitidissimo, cingulo ferrugineo; antennis thorace brevioribus. (6).

\section{**. b.}

Os linguâ acutâ, auriculatâ ; valvularum loris elongatis.

Labium pectinatum, appendiculatum.

Abdomen subovale, ano rimâ perpendiculari.

Corpus subvillosum.

Obs. Antenna feminece apice recurva. Labium masculum pectinatum, absque appendice; corpus elongatum; anus rimâ nullâ.

quadri- 13. M. atra, cinereo-subpubescens; abdomine convexo, segmentis margine albis; pedibus, anoque, villoso-pallidis. (1)

rulicun- 14. M. atra, rufescente-pubescens; abdomine seg-
du. mentis margine albis; tarsis, tibiisque posticis, fulvis. (2)

faripes. 15. M. nigro-ænea, nitida; pedibus flavis. (3)

seladonia.16. M. nigro-ænea, pallido-subpubescens; abdomine segmentis margine pallidis. (4)

arata. 17. M. virdi-ænea, nitida; abdomine nigroæneo. (5)

leucopus. 18. M. ænea; abdomine nigro; antennis subtus fulvis; tarsis albidis. (6)

Alorio. 19. M. ænea; metathorace cærulescenti ; abdodomine nigro. (7) 
20. M. nigra, nitens; antennis subtus fulvescen-minuta. tibus. (8)

21. M. atra, albido-villosula; abdomine subovato; villosula. antennis subtus, tarsisque, rufescentibus. (9)

22. M. atra, glabriuscula; abdomine nitidissi-minutissimo. (10)

ma.

23. M. nigra, glabriuscula; antennis subtus flavis; nitidiusmaxillis, labio, tarsisque, albidis. (11)

24. M. atra, pallido-villosula; abdomine nigro, laevis. lævi, nitidissimo. (12).

25. M. atra, pallido-villosula; abdomine subpube-punctulascenti, punctulato, segmento primo lævi, ${ }^{\text {to. }}$ nitidissimo. (13)

26. M. nigra, griseo-subpubescens; abdomine sub- malachu-
ra. tomentoso. (14)

27. M. nigra; antennis thorace longioribus, ful-fulvicor vescentibus; abdomine nitido, segmentis intermediis basi albis. (15)

28. M, nigra, rufescente-pubescens; abdomine sub-fulvotomentoso, segmentis margine fulvis, inter- ${ }^{\text {cincta. }}$ mediis basi utrinque pallidis. (16)

29. M. atra, albido-subvillosa; abdomine segmen-albipes. tis intermediis rufis, fasciâ, punctisque lateralibus, nigris; labio flavo. (17)

30. M. atra, cinereo-subvillosa; abdomine seg-abdomimentis anticis rufis, maculâ mediâ, punctis- nalis. que lateralibus, nigris. (18)

31. M. atra, glabriuscula; abdomine nitidissimo, obovata. obovato, segmentis basi albis. (19)

32. M. atra, rufo-subpubescens; thorace fer-lavigata. rugineo; 
rugineo; abdomine nitidissimo, segmentis intermediis basi pallescentibus. (20)

* leucozo- 33. M. atra, cinereo-pubescens; abdomine segnia. mentis intermediis basi albis. (21)

xantho- 34. M. nigra, rufo-pubescens; thorace ferrugineo; pus. abdomine segmentis utrinque basi pallidis; pedibus posticis testaccis. (22)

quadrino- 35. M. atra, cinereo-subpubescens; abdomine subtata. incano, segmentis duobus intcrmediis basi utrinque albis. (23)

lugulris. 36. M. atra, albido-subpubescens; abdomine segmentis intermediis basi utrinque, plantisque, albis; antennis thorace longioribus. (24)

sexnotata.37. M. aterrima, pube incanâ; abdomine segmentis tribus intermediis basi utrinque albis; alis apice nigris. (25)

$$
\text { **. c. }
$$

Os linģuâ acutiusculâ, auriculatâ, sxpius hastatâ, apice reflexâ.

Lalium anticè obtusangulum, supra tuberculo munitum.

Femora postica flocculo instructa.

Anus fimbriatus.

Corpus villosum.

Obs. Mas alisque fiocculo atque fimlriat.

Lathama-38. M. atra, glabriuscula; abdomine nigro, cinna. gulo antico, ano, scopâque, rufis. (1)

Rosce. 39. M. atra, cinereo-subvillosa; abdomine cingulo antico rufo; scopâ versicolori. (2) 
40. M. atra, cinereo-villosa; abdomine nigro, cin-zonalis. gulo rufo; pedibus posticis piceis. (3)

41. M. nigra, cinereo-subpubescens; abdomine cingulata . glabriusculo, cingulo ferrugineo utrinque puncto nigro. (4)

42. M. nigra, cinereo-subvillosa; thorace rufescen- Schrankti ; abdomine cingulo rufo, segmentis pos- ${ }^{\text {ella. }}$ ticis flavo-ciliatis. (5)

43. M. nigra, cinerèo-subvillosa; thorace rufescen-afinis. ti ; abdomine subtomentoso, segmentis posticis flavo-ciliatis. (6)

- 44. M. nigra, griseo-villosa ; thorace pube rufâ ; fulvago. abdomine punctulato, nitido; pedibus posticis, anoque, fulvis. (7)

45. M. nigra, albicante-subvillosa; thorace, ano-allicans. que, ferrugineis; tibiis plantisque posticis fulvis. (8)

46. M. aterrima, subvillosa; abdomine nitido; pilipes tibïs posticis scopâ albidâ. (9)

47. M. atra, albido-pubescens; thorace hirsuto cineraria, fasciâ atrâ; abdomine atro-cærulescenti. (10)

$\checkmark$ 48. M. atra, villos̀a; trunco hirsuto-albicanti. (11) pratensis.

49. M. atra, villosa; trunco supra hirsuto-rufo. (12) thoracica 50. M. atra, subvillosa; thorace hirsuto-flave-melanocescenti; abdomine ovato, nigro. (13) phala.

51. M. nigra, pallido-subvillosa; thorace hirsuto-nitida. fulvo; abdomine nitido; tibiis pósticis scopâ versicolori. (14)

52. M. nigra, albido-pubescens; thorace rufescenti; tilialis. tibiis posticis fulvis, scopâ fulvo-aureâ. (15) 
Mouffet- 53. M. nigra, pallido-pubescens; abdomine piloso, ella. nigro-æneo; thorace, digitis, tibiisque posticis, rufis. (16)

nigro- 54 . M. nigra, fulvo-pubescens; capite anoque atris; anea. abdomine subhirsuto, nigro-æneo. (17)

atriceps. 55. M. nigra, rufescente-villosa; capite atro; tarsis rufis. (18)

bimacu- 56. M. nigra, rufescente-villosa; capite atro; ventre lata. basi utrinque maculâ rufâ. (19)

Trimme- 57. M. nigra, grisescente-pubescens; abdomine rana. hirsutulo; tibiis posticis scopâ versicolori. (20)

varians. 58. M. atra; thorace, abdominisque basi, hirsutofulvis; tibiis posticis scopâ versicolori. (21) helvola. 59. M. nigra, albido-villosa; thorace, abdominisque basi, hirsuto-ferrugineis; tibiis posticis scopâ flavescenti. (22)

Gwynana 60. M. atra, villosa; thorace, abdomine anticè, tibiisque posticis scopâ, ferrugineis. (23) angustior. 61. M. nigra, rufo-subvillosa; thorace, pubescenti; femoribus, pedibusque quatuor anticis, piceis; posticis ferrugineis. (24)

picicornis.62. M. nigra, grisescente-subvillosa; capite atro; antennis piceis; abdomine fusco. (25)

spinigera. 63. M. nigra, hirsuto-cinerascens; maxillis longitudine capitis atri, basi spinâ filiformi armatis (26)

armata. 64. M. nigra, cinerascente-villosa; maxillis longitudine capitis, basi dente armatis. (27)

subdenta-65. M. nigra, cinerascente-villosa; facie anticè ta. 
barbâ albâ; maxillis longitudine capitis, basi obtusangulis. (28)

66. M. nigra, pallido-villosa; thorace fulvescenti; picipes. abdomine fusco; pedibus rufo-piceis. (29)

67. M. nigra, pallido-villosa; thorace hirsuto-fer-angulosa rugineo; capite posticè utrinque rectangulo. (30)

68. M. atra; thorace, abdomineque stpra, hirsutis, fulva. fulvo-aureis. (31)

- 69. M. atra, hirsuta; thorace, pedibusque posticis, Clarkella. fulvis. (32)

70. M. nigra, grisescente-subhirsuta ; thorace ab-Smithella domineque hirsutis, fulvescentibus, segmen-tis margine albidioribus. (33)

71. M. nigra, fulvo-subhirsuta; labio tridentato; tridentd digitis testaceis. (34)

72. M. atra, albido villosa; maxillis basi denticulo denticuld armatis; labio tridentato; abdomine strigis ${ }^{t a .}$ tribus albis. (35)

73. M. atra, thorace fulvo; abdomine fasciis tri-nigriceps. bus villoso-rufescentibus. (36)

74. M. nigra, cinerascente-villosa; thorace flave-rufitarsis. scenti; abdomine segmentis margine albidis; antennis subtı!s, digitisque, rufis. (37)

75. M. nigra, pallido-subvillosa; thorace fulvo; fuscipes. abdomine segmentis margine albidis; tibiis posticis scopâ fuscâ. (38)

76. M. atra, pallido-subvillosa; abdomine segmen- Listerella tis margine albidis; thoracis disco subpiloso, nigro. (39)

VOL. II. 
folricrus. 77. M. nigra, grisescente-villosa; abdomine fasciis tribus pallidis; tibiis posticis scopâ fulvâ. (40) lanifrons. \%8. M. nigra, supra fulvo-pubescens; abdomine ovato, basi fulvo-villoso; segmentis apice pallidioribus. (41)

contigna. 79. M. atra, cinereo-villosa; abdomine segmentis margine villoso-albis. (42)

pnlescens. 80. M. nigra, cinereo-villosa; abdomine ovali; labio subcornuto. (43)

hamnr- 81. M. atra, cincreo-subpubescens; abdomine segrhoidalis. mentis posticis utrinque margine albis; ano ferrugineo. ( 14$)$

- chrysosce-82. M. nigra, cinereo-subpubescens; abdomine lis. nitido, fasciis interruptis albidis; ano, tarsis, tibiisque posticis, testaceis. (45)

dorsata. 83. M. nigra, cinereo-subvillosa; thorace fulvo; abdomine fasciis tribus albis, anticâ interruptâ ; tarsis rufis. (46)

Wilkella. 84. M. atra, cincreo-subvillosa; abdomine segmentis intermediis utrinque margine albis; plantis, tibiisque posticis, rufis. (47)

proxima. 85. M. atra, cinereo-subpubescens; thorace grisescenti; abdomine utrmque strigis tribus albis; scopâ pallidâ nitenti. (18)

Caicana. 86. M. atra, nitida, albido-subvillosa; frontis angulis, nasoque, albis. (-1!n)

lalialis. \&7. M. nigra, palliclo-villosa; thorace fulvescenti; facie anticè albidâ; abdomine segmentis margine utrinque pallidis. (50)

Jeuinel-88. M. nigra, pailido-villosa; thorace, tarsisque in rufescen- 
rufescentibus; abdomine segmentis intermediis utrinque strigâ albidâ. (51)

89. M. atra, cinereo-villosa; abdomine ovato; seg-ovatula. mentis margine albidis. (52)

90. M. nigra, lutescenti-villosa; abdomine sub-larlata. ovato; segmentis margine membranaceis, albido ciliatis. (53)

91. M. atra, hirsuto-canescens; abdomine lævi larlila- $\checkmark$ lanceolato; facie anticè barbâ densâ ar- ${ }^{\text {lris. }}$ genteâ. (54)

92. M. atra, albido villosa; abdomine subovali, larbatu punctulato; segmentis intermediis margine ${ }^{l a}$. utrinque albis. (55)

93. M. atra, cinereo-villosa; abdomine subovato, Collinsonnitido; segmentis posticis margine albi- ${ }^{\text {ana. }}$ dis. (56)

94. M. cinereo-subpubescens; thorace rufo; me-comlinatathorace utrinque fimbriâ pallidâ; abclomine ${ }^{t a}$. fasciis tribus, interruptis, albidis. $(5 \boldsymbol{7})$

95. M. atra, supra nudiuscula; metathorace utrin-nudiuscuque, tibiisque posticis, pallido-lanatis. (58)

$\checkmark$ 96. M. atra, cinereo-villosa; thorace fulvo; abdo-albicrus. mine ovato, pilosulo, strigis tribus albis; scopâ versicolori. (59)

97. M. atra, supra nudiuscula; abdomine convexo, connecnitido; tarsis omnibus, tibrisque posticis, ${ }^{\text {tens. }}$ rufis. (60)

98. M. nigra, albido-subvillosa; abdomine punc-sulincana tulato; digitis omnibus, plantisque posticis, rufis. (61) 
digritalis. 99. M. atra, cinereo-subvillosa; tibiis posticis scopâ argenteâ; digitis ferrugineis. (62)

Shawella.100. M. atra, glabriuscula; abdomine nitidissimo, subcuneiformi, segmentis intermediis utrinque albo-ciliatis; scopâ versicolori. (63)

- minutula. 101. M. atra, glabriuscula; antennis subtus fulvescentibus; abdomine nitido; tibiis posticis scopâ argenteâ. (64)

nana. 102. M. atra, albido-villosula; abdomine nitido, segmentis basi punctulatissimis; tibiis posticis scopâ argenteâ. (65)

parvula. 103. M. atra, cinereo-subvillosa; abdomine subrotundo. (66)

pilosula. 104. M. nigra, cinereo-subpilosa; capite atro; abdomine subovali, segmentis margine membranaceis; digitis ferrugineis. (67)

xanthura. 105. M. atra, cincreo-subpubescens; ano, tibiis plantisque posticis, rufescentibus; abdomine fasciis subinterruptis, albidis. 68)

convexius-106. M. nigra, griseo-subpubescens; abdomine cula. ovato, convexo, segmentis margine pallidis; tibiis plantisque posticis rufis. (69)

fuscata. 107. M. nigra, grisescente-subpubescens; thorace fusco; abdomine ovato, convexiusculo, segmentis margine pallidis. (70)

Afxuliella 108. M. atra, fulvo-villosa; thorace ferrugineo; abdomine subcordato, fasciis tribus, interruptis, pallidis. (71)

tricincta. 109. M. nigra, cincreo-subpubescens; thorace flavesccnti; abdomine ovato, basi subretuso, fasciis tribus, angustis, pallidis. (72) 
110. M. atra, grisescente-subpubescens; thoracis chrysura. limbo fulvescenti; abdomine ovato, basi retuso; ano fulvo-aureo. (73)

111. M. atra, pallido-villosa; abdomine fasciis tri- Swambus albidis; pedibus posticis fulvo longis- ella. simè lanatis. (74)

\section{APIS. (b)}

Os proboscide fractâ, inflexâ, linguam cylindricam, elongatam, exerente.

Antennce mediæ, aculeatis articulis 13; maribus articulis 14 .

Oculi laterales, subovales, integri.

Ala planæ.

Aculeus punctorius, reconditus. *. a.

Os proboscide quinquefidâ; linguâ acutâ; palpis exteriorioribus sexarticulatis, interioribus quadriarticulatis.

Antenne clavatæ in omni sexu.

- Labium ovale.

Corpus subpilosum.

Obs. Caput masculum anticè truncatum.

1. A. atra, supra glabriuscula; pedibus posticis ursina. fulvo-hirsutissimis. (1)

2. A. atra, nitida, glabriuscula; antennis dimidiato- Lincella. rufis. (2)

3. A. atra, nitida, glabriuscula: digitis rufis. (3) Bankiana (b) Tab. 4-13. 


$$
\text { *. b. }
$$

Os crassum, proboscide quinquefidâ; palpis ex, terioribus sexarticulatis, interioribus quadriarticulatis.

Antenna rectiusculæ, filiformes in omni sexu.

Latium subovale.

Abdomen glaberrimum.

Corpus subvillosum. - Goodeni- 4. A. atra; tuberculis, squamulis, scutellique punc-
ana.

tis, flavis; abdomine fasciis flavis, nigrisque, alternis. (1)

- alternata.5. A. atra, griseo-subvillosa; tuberculis, squamulisque flavescentibus; abdomine fasciis flavis, nigrisque, alternis; scutello immaculato. (2)

Lathburi-6. A. atra, cinerascente-subvillosa; scutelli punctis ana. duobus, abdominisque fasciis posticis, flavis, anticâ rứà. (3)

varia. 7. A. atra; scutello, tarsis, tibiis extra, abdominisque fasciis posticis, flavis, antic̀ ruf

fava. 8. A. atra, subvillosa; squamulis fulvis; abdomine fasciis flavis, ferrugineisque, alternis. (5)

rufiven- 9. A atra; scutelli punctis fulvescentibus; abdotris. minis ventre ferrugineo, tergo rufo, nigro, flavoque fasciato. (6)

Marsham-10. A. atra; antennis, squamulisque ferrugineis; ella. scutelli punctis, abdominisque fasciis, flavis, anticis tribus interruptis. (7)

cornigera.11. A. atra; labio subcornuto; abdominis ventre basi ferrugineo, tergo maculis, fasciisque flavis, variegato. (8) 
12. A. atra; labio subcornuto; abdominis ventre; subcornumaculisque tergi anticis, ferrugineis, pos- ${ }^{t a}$. ticis sex, anoque, flavis. (9)

13. A. atra; labio subcornuto; abdomine maculis Coprece. anticis ferrugineis, intermediis quatuor, fasciâ, anoque, flavis. (10)

14. A. atra; abdomine fasciâ anticâ ferrugineâ; lineola. maculis quatuor intermediis, fasciâ, anoque, flavis. (11)

15. A. atra; scutello sulphureo; abdomine flavo; fucata. basi ferrugineo, fasciis quatuor nigris. (12)

16. A. atra, cinereo-villosula; abdomine piceo, lencophmaculis septem sulphureis; antennis suprat thalma. nigris. (13)

17. A. atra; tarsis rufis; abdomine fasciis sex sex-cincta flavis, anticis tribus interruptis. (14)

18. A. atra; scutelli punctis duobus, abdominisque Schceffera maculis sex, fasciâ, anoque, flavis. (15)

19. A. atra; scutelli punctis duobus, abdominisque connexa. maculis sex, fasciis tribus, pedibusque, flavis. (16)

20. A. atra; pedibus ferrugineis; scutelli punctis, Jacobece. abdominisque maculis fasciisque, flavis; antennis supra nigris. (17)

21. A. atra; antennis nigricantibus; scutelli punc-flavo-fictis duobus contiguis, abclominisque maculis, ${ }^{t a}$. fasciisque, flavis. (18)

22. A. atra; antennis nigricantibus; scutello, ab-Solidagidominisque maculis, faciisque, flavis; seg- $^{\text {nis. }}$ mento primo immaculato. (19) 
picta. 23. A. atra; antennis nigricantibus; abdomine ferrugineo, maculis quatuor, fasciisque duabus, scutelloque, flavis. (20)

rufo-pic- 24. A. atra; antennis nigricantibus; abdomine ta. ferrugineo, maculis sex, ano, scutelloque, flavis. (21)

Hillana. 25. A. atra; labio, squamulis, scutelloque, ferrugineis; abdomine rufo, maculis quatuor, fasciisque tribus, lutescentibus. (22)

ochrosto- 26. A. atra; scutello sanguineo; abdomine rufo, ma. maculis, fasciisque interruptis, flavis, variegato. (23)

ruficornis.27. A. ferrugineo; thorace lineis tribus longitudinalibus, atris; abdomine maculis, fasciisque, flavis. (24)

xantho- 28. A. atra; antennis, scutellique punctis, ferrusticta. gineis; abdomine rufo, maculis duabus flavis. (25)

Falriciel-29. A. atra; antennis rufis, nigro annulatis; $a b$ la. domine ferrugineo, maculis duabus flavis.(26) quadri- 30. A. atra; abdomine ferrugineo, maculis quatuor notata. flavis; antennis, pedibusque, nigris. (2 $\tau$ ) flavo-gut-31. A. atra; antennis fulvis; abdomine rufo, punctata. tis quatuor luteis. (28)

mufo-cinc-32. A. atra; scutello ferrugineo; abdomine fusco, ta. punctis quatuor luteis; fasciâ, vcntreque, rufis. (29)

Sheppard-33. A. atra; scutello ferrugineo; abdomine fusco, ana. immaculato. (30)

ferrugi- 34. A. atra; antennis, pedibus, abdomineque, fernata. rugineis; labio subcornuto. (31) 


$$
\text { **. } a \text {. }
$$

Os crassum, proboscide septem-fidâ, subinvo-

lutâ ; palpis exterioribus quinquearticulatis, interioribus biarticulatis.

Antennce filiformes in omni sexu.

Labium subquadratum.

Abdomen breve, acutum.

Corpus villosum.

35. A. aterrima, albido-villosa; abdomine segmen-punctala. tis utrinque puncto albo; scutello bidentato. (1)

$$
\text { **. b. }
$$

Os crassiusculum, proboscide septem-fidâ, valvulis obtusis; palpis exterioribus exarticulatis, interioribus biarticulatis.

Antennœ rectiusculæ, filiformes:

Labium anticè curvum.

Abdomen subconicum.

Corpus tomentoso-maculosum.

$\checkmark 36$. A. nigra; trunco, abdomineque, albido varie-variegata gatis; pedibus ferrugineis. (1)

$$
\text { **. c. } 1 \text {. } a \text {. }
$$

Os proboscide septemfidâ, subinvolutâ; palpis omnibus biarticulatis.

Antenne filiformes in omni sexu.

Labium inflexum.

Abdomen conicum, rectum, acutissimum, vertre glabro.

Corpus subvillosum.

yoL. II,

c

Obs, 
Obs. Abdomen masculum ano spinoso, segmento septimo olsoleto.

conica. 37. A. atra; scutello bidentato; abdomine conico, segmentis margine albidis; ano femineo, acu. tissimo, masculo multidentato. (1)

inermis. 38. A. atra; scutello inermi; abdomine masculo lineari, segmentis margine albis, ano multidentato. (2)

$$
\text { **. c. } 1 \text {. } \beta \text {. }
$$

Os proboscide septemfidâ, subinvolutâ ; palpis omnibus biarticulatis.

Antenne filiformes.

Labium inflexum.

Abdomen subcylindricum, obtusum, ano incurvo; ventre glabro.

Corpus subvillosum.

punctula-39. A. nigra, punctulatissima; scutello bidentato; tissima. abdomine segmentis margine decoloribus.(1) phropte- 40. A. atra, punctulatissima; albido-subpubescens; $r a$. ano rectangulo. (2)

$$
\text { **. c. } 2 \text {. } \alpha \text {. }
$$

Os proboscide septemfidâ, subinvolutâ; palpis omnibus biarticulatis.

Antenna sxpius filiformes.

Lalium inflexum.

Aldomen femineum horizontale, rectum, supra planiusculum; ventre hirsuto.

Corpus villosum. 
41. A. fulvescente-pubèscens; abdomine brevi, ano Willugh nigro; antennis masculis articulo extimo ma- ${ }_{\text {liella. }}$ jori, manibus dilatato-ciliatis. (1)

42. A. cinerascente-pubescens; abdomine femineo centuncis subcordato, segmentis märgine albidis; mas- laris. culo subgloboso. (2)

13. A. pallido-pubescens; thorace fusco; maxillis maritima, magnis prominentibus; abdomine oblongo, segmentis margine albicartibus. (3)

44. A. griseo-pubescens; abdomine femineo sub-ligniseca, ovali; masculo subgloboso, ano emarginato. (4)

45. A. lanuginoso-flava; capite, anoque, atris. (5) circum46. A. aterrima, villosa; thorace, abdominisque xanthobasi, lanuginoso-flavescentibus. (6) melana.

$$
\text { * *. c. } 2 \text {. } \beta \text {. }
$$

Os proboscide septemfidâ, subinvolutấ; palpis exterioribus exarticulatis, interioribus biarticulatis.

Antenne femineæ subclavatæ.

Labium inflexum.

Aldomen subglobosum, ano incusvo, ventre femineo hirsuto.

Corpus villosum.

Obs. Aldomen masculum ano inflexo, spinoso; antenne filiformes.

47. A. albido-villosa; abdomine maculis flavis, manicatc. lateralibus; ano masculo inflexo, quinquedentato. (1) 
Os proboscide septemfidâ; palpis exterioribus biarticulatis, interioribus exarticulatis. Artenne subclavatæ.

Labium inflexum.

Corpus elongato-cylindricum, ventre femineo subhirsuto.

Obs. Antenna mascula filiformes.

mrxillosa 48. A. atra, supra glabriuscula; maxillis prominentibus, intus barbatis; abdomine seg-. mentis margine albis. (1) 7. Anrisom- 49. A. atra, cinerco-villosa; abdomine masculo in-
zis. curvo, ventre basi cornuto, ano obtusè bidentato. 2) Compra- 50. A. atra, glabriuscula; ano masculo inflexo,
nularum. acutè bidentato, ventre basi gibbo. (3)

trunco- 51. A. atra; abdominis basi transversè carinato, ruin. seymentis margine albidis; ano masculo inflexo, inermi. (4)

$$
\text { **. c. } 2 \text {. } \delta \text {. }
$$

Os proboscidc septemfidâ, subinvolutâ; palpis exterioribus quadriarticulatis, interioribus biarticulatis.

Antennce subclavatic.

Lalium inflexum.

Corpus subcylindricum, villosum, interdum hirsutum, ano subincurvo, ventre femineo livsuto.

Obs. Antone mascular fliformes. 
52. A. aterrima, albido subvillosa; abdomine seg-leucomcmentis margine utrinque albis, ventre lanâ lana. cinerascenti. (1)

53. A. atra, cinereo-subvillosa ; scutello bidentato; spinulosa. ano masculo inflexo, spinuloso, ventre basi cornuto. (2)

+ 54. A. atra, griseo-villosa; abdomine nitido, atro- Leaiana. cærulescenti, ventre lanâ ferrugineâ. (3)

$\checkmark$ 55. A. corpore femineo atro, albido-subpubescens; cerulcabdomine cærulescenti, segmentis margine albicantibus, ventre lanâ atrâ : corpore masculo æneo, fulvo-pubescente; ano bidentato. (4)

r 56. A. nigra, rufo-villosa; abdomine segmentis Tunensis. margine pallidioribus; ano masculo cmarginato. (5)

$\checkmark 57$. A. corpore femineo atro, hirsuto; fronte bi-bicornis. corni; abdomine æneo, hirsutie rufâ : corpore masculo hirsuto-cinerascenti; fronte aibidâ; abdomine xnenco, hirsutie rufa, ano integro. (6)

$\checkmark$ 58. A. hirsuta, aterrima; abdomine, tarsisque qua-bicslor. tuor posticis, hirsuto-ferrugineis. (7).

$$
\text { **. d. } 1 \text {. }
$$

Os crassum, proboscide septemficiâ, rectâ, subulato-conicâ; laciniis interioribus involutis, exteriorum longitudine; palpis cxterioribus sexarticulatis, interioribus biarticulatis.

Antennce femineæ subclavatæ, masculæ longitudine corporis.
c 3
Latium 
Lalium anticè einarginatum.

Corpus villosum.

Inngicor-59- A. nigra, pallido-villosa ; thorace, abdominisnis. que basi, hirsuto-fulvis; ano femineo pallido. (1)

lingnaria.60. A. hirsuto-cinerascens; abdomine nigro. (2) pollinaris.61. A nigra, albido pubescens; thorace flavescenti ; abdomine fusco, polline pallido. (3)

Druriella.62. A. nigra, hirsuto-cinerascens; antennis subtus fulvis; abdomine segmentis posticis utrinque mucronatis. (4)

$$
\text { * *. d. } 2 \text {. } \alpha \text {. }
$$

Os crassum, proboscide septemfidâ, rectâ, subulato-conicâ; laciniis interioribus quàm exteriores brevioribus; palpis exterioribus sexarticulatis, interioribus biarticulatis.

Antenne feminex subclavatæ, masculæ thorace breviores.

Latium subquadratum, verticale.

Corpus villosum, interdum hirsutum.

$\checkmark$ Limacula-63. A. nigra, cinereo-subvillosa ; facie anticè, oreta. que, rufescentibus; ano tomentoso-incano.(1) furcata. 61. A. carpore femineo nigro, griseo-pubescenti; facie anticè, labio, anoque, villoso-ferrugineis :

corpore masculo atro, cinerco-pubescenti; facie anticè, labioque, flavis; abdomine apice furcato. (2) 
65. A. atra, villoso-pallescens; thorace flavescen-vulpina. ti; abdomine segmentis margine pallidis; femoribus intermediis magnis, clavatis. (3)

66. A. atra, cinereo-subvillosa; thorace flavescen-rotundata ti ; facie anticè fulvâ ; abdomine subgloboso, segmentis margine albis. (4)

67. A. nigra, fulvo-pubescens; abdomine segmen-pallicinctis margine pallidis. (5)

68. A. atra, albido-subvillosa; abdomine subglo-sulgroboboso. (6)

69. A. corpore femineo atro, hirsuto; tibiis posticis retusa. scopâ fulvo-aureâ :

corpore masculo nigro, hirsuto-fulvo; ano nigricanti; pedibus intermediis elongatis, crinito-pectinatis. (7)

70. A. hirsuto-fulva; ano nigro; plantis interme- Haworth diis extrorsum barbatis. ( 8 )

71. A. cæruleo-virens, glabriuscula, cylindrica; ab-cyanea. domine cuneiformi; ore masculo albo. (9)

$$
\text { **. d. 2. } \beta \text {. }
$$

$O s$, proboscide septemfidâ, rectâ, conicî; valvulis corneis, fornicatis; laciniis interioribus quàm exteriores brevioribus; palpis exterioribus sexarticulatis, interioribus, biarticulatis. Antennic subclavatæ; mascula thorace breviores.

Labium tuberculo munitum, anticè emarginatum.

Corpus subhirsutum.

72. A. violaced, supra glabra; alis nigricantibus. (1) iricolor,

$$
\text { c } 1 \quad \text { **. } \mathrm{e} \text { : }
$$




\section{**. e. 1 .}

Os proboscide septemfidâ, subinvolutâ; laciniis interioribus brevibus, obtusis; palpis exterioribus exarticulatis, interioribus biarticulatis.

Antennce filiformes, scapo fusiformi.

Labium lineare, planiusculum.

Stemmata in triangulo.

Tilice posticæ apice inermes.

Corpus villosum.

metifica. 73. A. corpore femineo pubescenti; thorace subgriseo; abdomine elongato, conico, alis corpore dimidio brevioribus; tarsis rufescentibus :

corpore neutro pubescenti; thorace subgriseo; abdomine subprismatico; plantis posticis intus transversè striatis:

corpore masculo pubescenti; trunco tomentoso-fulvescenti; oculis posticè conniventibus; alis corpore longioribus. (1)

**. e. 2 .

Os proboscide septemfidâ, subinvolutâ; laciniis interioribus brevibus, obtusis; palpis exterioribus exarticulatis; interioribus biarticulatis.

Antennce subfiliformes.

Labium lineare, inæquale.

Stemmata in lineâ curvâ.

Corpus hirsutissimum, 
74. A. hirsuto-flavescens; thorace fulvo. (1) Musca-

75. A. hirsuto-cinerascens; thorace, abdomineque, Francilfulvis. (2)

76. A. hirsuto-flavescens; thorace fulvo; abdo-foralis. mine maculis, fasciisque, atris. (3)

77. A. hirsuto-flavescens; thorace, anoque, fulvis; Soncerliabdomine fasciis duabus nigris. (4)

78. A. hirsuto-pallida; thorace, anoque, fulvis; Beckwithabdomine fasciâ mediâ atrâ. (5)

79. A. hirsuto-pallida; thorace fulvo; abdomine Curtisella atro, basi rufescenti. (6)

80. A. hirsuto-albida; thoracis fulvescentis basi, Forsterabdominisque fasciis obscuris, nigricanti- ${ }^{\text {ella. }}$ bus. (7)

81. A. atra, hirsuta; thorace, anoque, ferrugineis.(8) agrorum.

82. A. hirsuto-pallida; thorace inter alas, abdomi-sylvarum. neque fasciis, nigris, ano rufescenti. (9)

$\checkmark$ 83. A. supra hirsuto-flava; thoracis fasciâ atrâ. (10) fragrans.

84. A. supra hirsuto-flava; thorace inter alas, ab- Latreilldomineque fasciis duabus, atris. (11)

85. A. supra hirsuto-flava; thorace inter alas, ab-Rossiella. dominisqué fasciâ, atris. (12)

s6. A. atra, hirsuta; thorace anticè, scutello, ano- Lecana. que, flavis. (13)

87. A. atra, hirsuta; ano flavescenti. (14)

Francisana.

83. A. atra, hirsuta; thorace anticè, scutello, ano-campesque inflexo utrinque, flavis; abdomine sub- ${ }^{\text {tris. }}$ globoso. (15)

89. A. supra hirsuto-flava, ano albido; thorace lucorum. fasciâ nigrâ. (16) 
Jonelle. 90. A. hirsuto-flava, ano albo; thorace abdomineque fasciâ atrâ. (17)

hortorum.91. A. atra, hirsuta, ano albo; thorace anticè, scutello, abdominisque basi, flavis; capite elongato. 18)

Srrimp- 92. A. atra, hirsuta, ano albo; thorace anticè, shiruna. scutello, abdominisque basi, flavis. (19)

Barlutel-93. A. atra, hirsuta, ano albo; vertice, thorace la. anticè, scutelloque, fulvis; abdomine subgluboso. (20)

Tunstall-94. A. atra, hirsuta, ano albo; thorace anticè, scuana. telloque, fulvescentibus. 21)

vestalis. 95. A. atra, hirsuta, ano albo, apice nigro; thorace basi flavo. (22)

virginalis 96. A. atra, hirsuta, ano albo; thoracis cingulo, abdominisque segmentis duobus anticis, flavis. (23)

terrestris. 97. A. atra, hirsuta, ano albo; thoracis basi, abdominisque fasciâ, flavis. (24)

Soroensis. 98. A. atra, hirsuta, ano albo. (25)

subinter- 99. A. atra, hirsuta, ano fulvo; thoracis basi, abrupta. dominisque fasciâ anticâ, flavis. (26)

Donovan-100. A. atra, hirsuta, ano rufo; thoracis abdomiella. nisque basi flavâ. (27)

Burrell- 101. A. liirsuto-flava, ano fulvo; thoracis abdoana. minisque subglobosi fasciâ atrâ. (28)

Cullum- 102. A. hirsuto-pallida, ano ferruginco; thoracis ana. abdominisque fascià atrâ. (29)

pratorum.103. A. atra, hirsuta, ano fulvo; thorace antice flavo. 30) 
SYNOPSIS SPECIERUM. (Apis.)

104. A. atra, hirsuta, ano rufo; thoracis limbo, Allinella: abdominisque lateribus, cinerascentibus. (31)

105. A. hirsuta, fusco-cinerascens, ano fulvo; tho-Derhamracis abdominisque fascià atrà. (32)

106. A. corpore femineo atro, hirsuto, ano rubro: lapidaria. corpore masculo supra atro, hirsuto, ano rubro; facie, thoracisque basi et apice, flavis. (33)

107. A. atra, hirsuta, ano fulvo; tibiis posticis cor-Raiella. biculà rufà. $(34)$

108. A. atra, hirsuta, ano fulvo; alis nigricanti-rupestris. bus. (35)

109. A. atra, hirsuta, ano fusco; capite masculo subterra subgloboso; maxillis supra tomentoso-ful- ${ }^{\text {nea. }}$ vis. (36)

10. A. hirsuta, aterrima. (37)

Harrise

ella. 


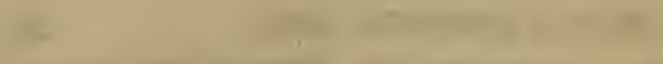

-

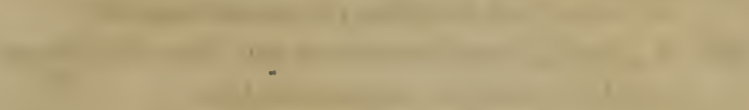

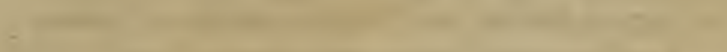

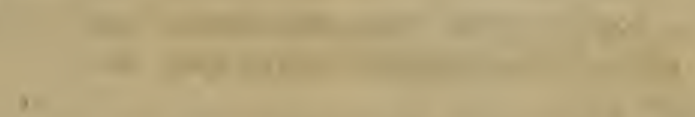

s.

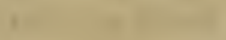

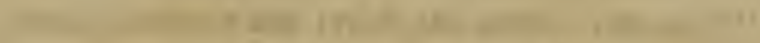
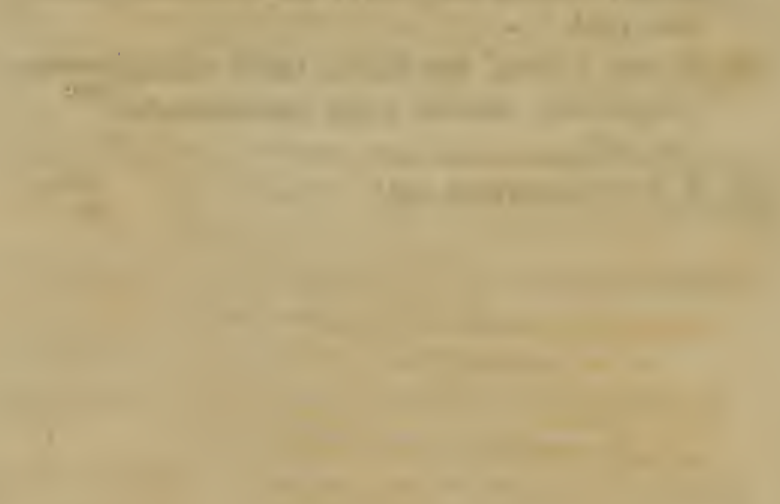

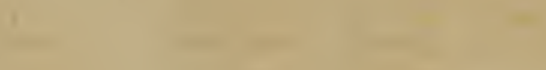

1

-

1 
MONOGRAPHIA

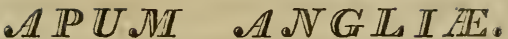

\section{PARS QUARTA.}

DESCRIPTIONES, SYNONYMA AUCTORUM, MUSEA in quibus species heic descriptæ asservantur, necnon OBSERVATIONES quasdam miscellaneas linguâ vernaculâ scriptas, complexa.

En istæ sunt partes viarum ejus.

Jol。

\section{O JEHOVA,}

Omnia ista animantia in $T_{E}$ sperant ut des illis escam tempore suo;

TE ipsis dante, illam colligunt, aperiente Manum Tuam satiantur bono;

TE recipiente spiritum eorum pereunt et in pulverem revertuntur;

Te emittente Spiritum Tuum creantur, et renovas faciem terræ.

Gloria $\mathbf{J}_{\mathrm{EHOV}}$ ⿸ erit in secula et lætatur JEHOV A operibus suis.

Canam JEHOV reflectam $\mathrm{S}_{\mathrm{API}} \mathrm{PNTI}$ E Ejus radios, quamdiu superero. Benedic anima mea $\mathrm{J}_{\mathrm{EHOV}} \mathrm{Ae}$. HALLELU-JAH. David. 


\section{( 32$)$ \\ MELITTA. (*.a.)}

succincta. 1. M. nigra, albido-villosa; thorace fulvo; abdomine ovato; segmentis margine albis.

Apis succincta thorace flavescente subvilloso; abdomine nigro, cingulis quatuor albis.

Lin. Syst. Nat. ed. 12, n. 18. Fn. Suec. 1694.

Vill. Ent. Eur. 3. n. 15.

Forst. Cat. Brit. Ins, n. 714. Apis, n.7.

Andrena succincta thorace hirto, fulvo; abdomine nigro, cingulis quatuor albis.

Fal. Ent. Syst. Em. n. 31.

Lin. Syst. Nat. ed. Gmel. p. 2792. n. 18.

Grew's Rarities, § 7. c. 1. p. 154.

FIG. Reaum. tom. 6. mem. 5. p. 131-39. tab.12. fig.1-13. Apis succinctu. Christii Hymenopt. p.185. tab.15. fig.7.

MUS. D. Smith Linuean. Latham, Marsham, Trimmer, Kirly. Long. Corp. Lin. $4 \frac{3}{4}$.

Hul. prope Londinum. Nidum in murorum cavitatibus secundum Reaumurium, in fistulis sambucinis auctore Grewio, cellulis e membranâ diaphanâ, tenuissimâ confectis, struit.

DESCR. Acul.

CORPUS nigrum, pube albescenti.

CAPut. Facies anticè pube, densà admodum, albicanti, posticè fulrescenti, tecta. Nasus glabriusculus, ruguloso-punctulatus. Antenne capitis longitudine, nigræ.

Truncus supra punctatus, pube fulvâ vestitus. Squamula nigro-picex. Alk hyalinæ, nervis nigrican- 
nigricantibus. Pedes nigri, albido-pilosi, fe-moribus posticis hirtis.

A в DOMEN fusco-nigrum, ovatum, acutum, supra valde convexum $\int$. gibbum; segmento primo punctulatissimo glabro, secundo basi et apice, reliquis apice, latè tomentoso-niveis.

Maris Antenne thoracis longitudine articulis arcuatis.

The Melitta here described, is the genuine Apis succincta of Linneus, as I find upon comparing it with the authentic specimen preserved in the Linnean cabinet: the rostrum, however, or proboscis, scarcely merits the epithet of subulatum which he has given to it. In the same cabinet there is another insect of this family, labelled by that great naturalist Apis marginata; this is much smaller than $M$. succincta, but in other respects it scarcely differs from it.

I have excluded the synonym of Geoffroy, referred to by Linneus for this insect, since it appears to me to belong rather to Apis rotundata of Fabricius. He places it next to Apis longicornis, and says of it "Cette abeille a beaucoup de rapport avec la précédente;" and again, "Le levre supérieure et le devant de la tête de l'insecte sont d'un jaune citron $(a)$." Both of which circumstances agree well with $A$. rotundata, but not at all with M. succincta. Gmelin and Villars refer to another

(a) Hist. Ins, Par, tom. 2. p. 413, n. 11.

synonym 
synonym of this author for our insect, which I have likewise excluded, as to me it appears intended for the species that I shall next describe. That this species is Reaumur's Abeille " qui fait son nid de meml-ranes soyeuses," appears evidently from a specimen of that insect which was sent by M. Latreille, the ingenious author of the work upon the Genera Insectorum noticed above $b$ ), for my inspection, under the name of Hylcus glutinosus. This specimen was rather smaller than ours, but there was no material difference between them.

Panzer's Andrena succincta (c) is very different from the true one; it appertains to another family of this genus, and seems very nearly related to Melitta Swammerdamella.

Linneus mentions the present species as very rare in Sweden; the aculeate sex has often been taken in the neighbourhood of London, but of the male I have seen only a single specimen, which is in the cabinet of Dr. Latham.

- fodiens. 2. M. nigra, albido-villosa; thorace fulvescenti; abdomine conico, basi subretuso; segmentis margine pallidis.

Apis syluestris in terra foramen sibi fodiens, an tertia Purchasii?

Willugh. in Rai. Hist. Ins. p. 244.

Apis nigra; thorace hirsuto fulvo; abdomine glabro incisuris albis.

Geoffr. Hist. Ins. Par. tom.2.p.411, n.7?

(b) Vol. 1. p. 80. (c) Fn. Ins. Germ. Init, n. 7. tab. 10. 
MELITTA. (*. a.)

Apis fodiens. Fourcroy. Ent. Par. n. 7 ?

FIG. Acul. Tal.15. fig. 1. Mas. ilid. fig. 2.

MUS. D. Marsham, Kirby.

Long. Corp. Lin. 5.

Hab. Barhamiæ, in floribus Jacolece femina semel atque iterum lecta; mas aggeres circum apricos volitat, sed rarus admodum. Multæ simul habitant, et foramina in terrâ fodiunt, teste Willughbio, terram egerentes ad modum vermium, ubi cellas quasdam rotundas ex albâ et tenui cute conficiunt, in quibus mel densum sordidum reponunt.

DESCR. Acul.

CORPUS nigrum, albido-pubescens.

Caput. Facies anticè pube densâ admodum albicanti, posticè fulvescenti, tecta. Nasus glabriusculus, ruguloso-punctatus. Antennce capitis longitudine, piceo-nigræ.

TRUNCUs supra punctulatissimus, pube fulvescenti mollis. Squamule pallidæ. Alce hyalinæ nervis nigricantibus. Fenora postica densiùs barbata.

Aвдомen elongatum, subconicum, acutum, supra tomento nigricanti, nisi a latere et sub lente vix conspicuo, vestitum, basi retusum et utrinque villosum; segmento primo punctulatissimo margine utrinque, secundo basi apiceque, reliquis apice, tomentoso-pallidis.

Maris Corpus magis angustum. Facies hirsutie densâ et longâ pallescenti. Antennce capite longiores. Squamule nigræ. Abdomen basi hirsutulum, segmentis margine villoso-pallidis. VOL. II.

D

The 
The aculeate sex of this and the preceding species are extremely similar to each other ; but the abdomen of $\boldsymbol{M}$. fodiens is proportionally longer, more conical, and much less convex; it is also rather retuse at its base. The males, however, are more strikingly distinguished. I am a little dubious as to the synonym I have quoted from Geoffroy, but I think it ought to be referred to this rather than to $M$. succincta, on account of its nidificating under ground. His description will suit either equally well. Concerning the identity of Willughby's Apis sylvestris in terrâ foramen sibi fodiens, with our insect, I have scarcely any doubt.

$$
\text { *. b. }
$$

annulata.3. M. atra; fronte maculatâ ; tibiis posticis albido annulatis.

Apis annulata nigra; fronte, annulisque pedum, abis. Lin. Syst. Nat. ed.12. \& Gmel. p.27\%9. n.33. Fn.

Suec. 1706.

Miill. Zool. Dan. 1909.

Fn. Frid. 647.

Fill. Ent. Eur. 3. n. 26.

Hylceus annulatus. Fal. Ent. Syst. Em. n. 12.

Vespa nigra; fronte, fiavâ.

Geoffr. Hist. Ins. Par. 2. p.3so. n. 14. NB.

liG. Tab. 15. fig. 3 .

MUS. D. Smith Linnean. Marsham, Haworth, Trimmer, Sowerly, Kirly.

Long. Corp. Lin. $2 \frac{1}{3}-3 \frac{1}{2}$.

Hab. Barhamix et alibi, in floribus Resedarum frequens.

DESCR. Acul.

CORPUS atrum.

Caput 
Caput obscurum, punctulatissimum. Antennce nigræ. Frons utrinque ad oculos maculâ luteâ.

Truncus obscurus, punctulatissimus. Squamulce puncto albo notatæ. Ale subhyalinæ, nervis nigris. Pedes nigri, tibiis posticis basi luteo-albis.

Ав оомеn atrum, lucidum, parvâ pube parum canescens.

$\operatorname{Var} . \beta$ antennis subtus piceis; frontis maculis, tibiarumque annulo, flavis; tuberculis dimidiato-flavis.

$\gamma$ frontis maculis obscurè ferrugineis; tutuberculis puncto flavo.

$\delta$ antennis subtus fulvis; frontis maculis triangularibus, rufis.

$\varepsilon$ antennis subtus obscurè rufescentibus; frontis maculis trapeziformibus, tuberculisque, flavis.

Maris Antenna capite longiores, subtus obscurè fulvæ, scapo crassiusculo. Facies infra antennas lutea, punctis duobus nigricantibus. Collare utrinque strigâ albâ. Plantæe posticæ, interdum et intermediæ, basi albidæ. Tibice anteriores antrorsum rufescunt. Aldomen punctulatissimum.

Var. $\beta$ fronte, tuberculisque, luteo-albis.

The insect I have here described agrees with the authentic specimens of Apis annulata in the LinD 2

nean 
nean cabinet; indeed, several distinct species are there placed together as varieties of it, which Linneus appears to have regarded merely as such. Panzer's Hylcus annulatus $(d)$ is a very different insect, and belongs to a male of my third family of this genus. The observation of Fabricius upon his "Moscham spirat," proves its identity, at least with one of this family.

a.nularis.4. M. atra; fronte maculatâ; tibiis omnibus flavo annulatis.

FIG. Sphex annulata atra, nitida; abdomine subpetiolato; tibiis quatuor posticis flavis, nigro annulatis.

Punzer. Fn. Ins. Germ. Init. n.53. tal.1.

MIUS. D. Sinith Linnean. Marsham, Hau'orth, Trimmer, Kirly.

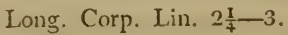

IIal. Barhamix cum pracedente.

DESCR. Acul.

CORPUS atrum.

CArut subtriangulare, anticè truncatum, obscurum, punctulatissimum. Antenna nigræ, subtus fulvx. Facies maculis duabus flavis, antrorsum acutis, infra antennas notata.

Trunces obscurus, punctulatissimus; tuberculis, punctoque squamularum, flaris. l'edes atri, tibiis omnibus basi flavis.

AвDOMEN specici hujusce abdomen præcedentis cxactissinè refert.

(d) Fn. Ins. Germ. Init. 11. 55, tab. 3. 
MELITTA. (*. b.)

Var. $\beta$ fronte, macularum loco, punctis duobus obscuris, palliclis, notatâ.

Maris Caput anticè rotundatum. Facies infra antennas luteo-alba. Antenna subtus dilutè fulvæ, scapo brevi conico. Truncus albidopilosulus, tuberculorum apice, tarsisque, albidis, tibiis luteis nigro annulatis.

$V$ Var. $\beta$ maxillis albis, apice fuscis; tibiis anticis antrorsum rufis, digitis nigricantibus.

$\gamma$ facie infra antennas pallidè rufescenti; nasi lateribus, antennisque nigris, scapo puncto flavescenti; tuberculis immaculatis; tibiis basi, anticis quatuor extrorsum, flavis; plantis flarescentibus; digitis obscurè ferrugineis.

$\delta$ facie maculis tribus distinctis, flavis; antennis subtus piccis, aliàs praccelenti simillimus.

This species appears to me to be very distinct from $M$. annulata: the head of the aculeates is rounder, and truncate before. The spots of the front, instead of being close to the eyes, are separated from them, and placed just below the base of the antennax. All the tibix are yellow at their base. The scapus, also, of the antennæ of the males is shorter, and more conical.

5. M. atra ; tibiis flavis, nigro annulatis; antennis clilatata. scapo patelliformi.

FIIG. Tal. 15. fig. 4 . 
MUS. D. Smith Linnean. Kirly.

Long. Corp, Lin. 3.

Hal. Barhamis, rarissima.

DESCR. Mas.

CORPUS atrum.

Caput triangulare. Maxille albx, apice fuscæ. Antenna nigræ, subtus apiceque fulvæ; scapo dilatato, subquadrato, concavo-convexo $\int$. pa-

. telliformi, dimidiato-luteo $(e)$. Facies infra antennas alba.

Truncus obscurus, punctulatissimus, cinerascenti-pilosulus; tuberculorum vertice, punctoque squamularum, flavis. Al.e subhyalinx, nervis nigris. Pedes flavi, femoribus, tibiarum posticarum annulo, anteriorumque quatuor maculâ, nigris.

Авдоме. parvâ pube, vix conspicuâ, respersum.

The extraordinary size and shape of the scapus of the antennæ, which much resembles a Patella, will, I think, sufficiently justify me for considering this insect as a distinct species. Were this circumstance a sexual distinction only, the other males of the family would have it as well as this, which is not the case. I observed a variety of this insect in the Linnean cabinet with the dilated joint entirely black.

(e) Tab. 1, *. b. fig. 8.

6. M. 
6. M. atra; fronte maculatâ; abdomine segmentosignata. . primo margine utrinque albo.

Vespa nigra; fronte, thoracisque basi, flavis.

Geoffr. Hist. Ins. 2. p. 379. n. 14.

Vespa pratensis. Fourcroy, Ent. Par. n.14. $\}$ Var. $\gamma$.

FIG. Sphex signata atra, nitida, immaculata; alis albis; fronte sub antennis maculis duabus flavis.

Panzer. Fn. Ins. Germ. Init. n. 53, tal.2.

MUS. D. Marsham, Haworth, Trimmer, Sowerly, Kirly, Long. Corp. Lin. $3 \frac{1}{3}$.

Hab. Barhamiæ, cum præcedentibus obvia.

DESCR. Acul.

CORPUS atrum, obscurum, punctulatissimum.

CAPut subtriangulare. Antenne subtus obscurè fulvæ. Facies anticè utrinque ad oculos maculâ fulvâ.

Truncus. Tuberculi vertice lutei. Squamulce puncto flavo. Alce hyalinæ, nervis nigris. Pcdes atri, tibiis anticis antrorsum obscurè rufis.

А В $о$ о $е N$ lucidum, punctulis minutissimis perseminatum; tergo valde convexo, segmento primo margine utrinque pilis brevibus, decumbentibus, niveis, ciliato.

Var. $\beta$ antennis subtus piceis, collare utrinque albo.

$\gamma$ antennis subtus piceis, collare tuberculisque luteis.

Maris Corpus pilis brevissimis, albidis, subincanum. Facies infra antennas albida. Antenne $\boldsymbol{e}$ scapo crassiusculo. 
This Melitta is larger than any of the preceding species of this family. It is entirely black, excepting only the underside of its antennæ, the spots on its front, a white fringe of short hairs on each side of the margin of the first dorsal segment of the abdomen, and its anterior tibix. Variety $\gamma$, appears to be Vespa nigra, fronte thoracisque basifavis of Geoffroy, I am not certain that this may not be inore than a variety. The aculeate sex of M. annulata, annularis, and signata have each a male agreeing with them in their peculiarities, a circumstance which furnishes a very strong proof that they are distinct species. On the other hand they all emit the same strong scent of balm, and are to be found usually on the same plants, viz. the different species of Reseda, to which they appear to confine themselves; this seems to indicate that. they are only varieties. But when we consider that the same circumstances attach to $M$. dilatata, so remarkably distinguished from the other males by the shape of the scapus of its antennæ, I think we are warranted in concluding that they point out the habit of a family, rather than of a species.

\section{**a.}

- gibba. 7. M. atra; abdomine ferrugineo, apice nigro.

Nomada gilba nigra; abdomine rufo, apice nigro.

Fal. Ent. Syst. Em. n. 12.

Lin. Syst. Nat. ed. Gmel. p. 2794. n. 202.

Vill. Ent. Eur. 3. Apis, n.68.

Ploss. Fn. Etrusc. Mantiss. n. 325. 
Apis nigra; abdomine rufo, nitido, apice nigro.

Geoff. Hist. Ins. Par. 2. p. 415. n. 17.

Apis rufescens. Fourcroy. Ent. Par. n.17,

Nomada succincta abdomen ellipticum basi rufum.

Scop. Ann. Hist. Nat. 4. p. 45. n. 2 ?

FIG Proabille noire à ailes brunes, à antennes en massue, dont le ventre est roux à extremité noire.

De Geer. 2. ptie. 2. Mem. 12. p. 755. tab.32. fg. 6.

Reaumur. 6. Mem. 4. p.96. tab.9.fig. 4-7.

Apis gilba. Christii Hymenopt. p.183. tab.15. fig. 3.

MUS. D. Banks, Marsham, Latham, Haworth, $M^{\mathrm{c}}$ Leay, Sowerly, Trimmer, Kirby.

Long. Corp. Lin. $3 \frac{1}{4}-4$.

Hal. Barhamiæ in floribus et aggeribus apricis, ubi profundè nidificat, passin ct frequens obyia.

DESCR. Acul.

CORPUS atrum, cinereo-subpubescens.

CAPU T punctulatissimum. Maxille nigræ, fasciâ ferrugineâ. Antennce subtus piceæ.

Truncus punctulatissimus. Squamule piceæ. Ala paululùm infuscatæ, nervis nigris. Pedes nigri, cinerascente-pilosuli; tibiis anticis antrorsum ferrugineis; digitis apice rufescentibus.

Авдомen ovatum, nitidum, supra convexum, acutiusculum, ferrugineum, segmentis duobus ultimis nigris.

$V a r . \beta$ minor; abdomine rufo, apice nigro; tibiis anticis rufis.

$\gamma$ tibiis anticis totis nigris.

Maris Facies anticè tomentoso-alba. Antennce submoni- 
submoniliformes, thorace breviores, fusconigræ. Abdomen subovale, segmentis tribus ultimis nigris.

That this is the genuine Nomada gilla of Fabricius appears from the specimens labelled by him in the cabinet of Sir Joseph Banks, with which I formerly compared it. He abserves, "variat sexu aldomine toto rufo." I believe I possess the three sexes of this insect, but in all mine the anus is black. Amongst my exotic Apes, I have one which agrees with this description, but it is not at all related to $M$. gibla, though, at first sight, it somewhat resembles it. It is a genuine $A p i s$, and seems to come near to $A$. variegata, but it has a singular labium, elongate, and I suppose, in its natural situation, inflected; gibbous at its base and shaped like an isosceles triangle, with the angle at the vertex somewhat rounded. Of how many joints its exterior palpi consist, I have not yet discovered. It may possibly be a connecting link between Apis variegata, and the family with an inflected lip. Scopoli says of his Nomada succincta, which is quoted, as synonymous with $M$. gilla, by Fabricius, and after him by Villars and Gmelin. "Ceriferâ vix minor, abdominis segmenta tria nigra sunt, margine tamen pallidè rufa. Nervi alarum majores pariter rufi." Circumstances which do not altogether agree with our insect. On this account I have added a mark of interrogation to 
this synonym. This species, in common with many others of the different families of this genus, is frequent in bare sunny banks. Reaumur found pupæ of three sizes in its cells $(f)$ whence we may conjecture that it has three sexes. I take $\alpha$ to be the female, and the smaller variety $\beta$ to be the neuter. From an examination of the proboscis of this species, this illustrious naturalist, as I observed above, and the Baron De Geer, were led to separate the genus, which they have called Proabeille, from Apis.

8. M. atra; abdomine rufo, apice, pedibusque, Geoffrel . nigro-piceis ; maxillis, tarsis, tibiisque anticis, ${ }^{l a}$. rufescentibus.

Geoffr. Hist. Ins. Par. 2. p. 416, n.17. NB.

FIG. Tal.1. fig. 5 .

MUS. D. Marshum, Latham, McLeay, Haworth, Sowerly, Trimmer, Kirly.

Long. Corp. Lin. $2 \frac{1}{2}$.

Hal. Barhamiæ cum præcedente frequentissima.

DESCR. Acul.

CORPUS atrum. glabriusculum.

Caput. Maxille itemque Labium rufæ. $A n$ tennce piceæ, subtus obscurè rufescentes.

Truncus nitidus, punctulatus. Squamula piceæ. Alce paululùm infuscatæ, splendidè iricolores, nervis ferrugineis. Pedes picei,

(f) Reaum. tom. 6. Mem. 4. p. 96, 97.

pallido 
pallido-pilosi; tarsis omnibus, tibiisque anticis antrorsum, rufis.

Aв DOMEN ovatum, nitidum, rufum, segmentis duobus ultimis nigro-piceis. Anus pallidopilosus.

Geoffioy supposes this insect to be merely a variety of the preceding species, but the difference of size so far exceeds the limits which separate the sexes in this genus, that I cannot help regarding it as distinct. It differs likewise in the colour of its maxillæ, lip, antennæ, legs, and abdomen.

Sphecoi- 9. M. aterrima; abdomine ferrugineo, basi apicedes. que nigro; alis nigricantibus.

Spluex gillba nigra; abdomine ferrugineo apice fusco; alis primoribus apice nigricantibus.

Lin. Syst. Nat. ed. 12. \& Gmel. 10. 2732. n.33. Fr. Shec, 1658.

Vili. Ent. Eur. 3. n. 40.

Fal. Ent. Syst. Em. n. 50 .

FIG. Apis rufa. Christii IIymenopt. p. 201. tal. 17 fig. 12.

MUS. D. Smith Linnean. Kirly.

Long. Corp. Lin. 4.

Hal. Barhamise cum præcedentibus, sed rarior.

DESCR. Acul.

CORPUS aterrimum, punctulatum, cinerea rariùs pilosulum.

Caput. Fertex pilositate parvâ, atrâ. Latium triangulare. Maxill $\mathfrak{c}$ fascià fuscâ. Anienne nigree.

Truncus 
Truncus. Thorax nitidus, glaber. Squamule nigræ. Alce infuscatæ, apice, nervisque, nigris; anastomosi ferrugineâ. Pedes atri, subpilosi, digitis rufescentibus.

Авдомеn subovale, nitilum;, segmento primo basi nigro, margine, duobus intermediis totis, antepenultimique basi, ferrugineis, reliquis nigris.

The species I have now described, very strongly resembles $M$. gilla; but the base, as well as the apex of the abdomen, is black. This part is also more oval, the lip is longer and triangular, and the wings have a black cloud at their tip. It is the genuine Sphex gibla of Linneus, as appears from the remains of the authentic specimen in the Linnean cabinet. I have excluded the synonym of $\operatorname{Scopoli}(g)$, since it is evidently intended for a different insect, nearly related to Sphex viatica and belonging to the Fabrician genus Pompilus. $M$. sphecoides appears to be the insect figured by Christius under the name of Apis rufa.

10. M. atra; antennis piceis, thorace longioribus; moniliabdomine cingulo rufo. cornis.

FIG. Var. f. Tal. 1. fig. 6

MUS. Kirly.

Jong. Corp. Lin. $3 \frac{\pi}{2}$.

trat. Barlamiæ, bis capta.

(g) Ent. Car. n, 786. 
DESCR. Mas.

CORPUS atrum, albido-pilosulum.

CAPU T pube incaná. Maxilla apice ferrugineæ. Facies infra antennas tomentoso-argentea. Antennce piceæ, thoracis longitudine, articulis arcuatis; certo situ tamen submoniliformes sunt $(h)$.

TRUnCUs pilis rarioribus subincanus. Thorax nitidus, punctatus. Squamula piceæ. Alae subhyalinæ, iricolores; nervis, excepto costali interiori fusco, testaceis. Pedes nigri, pallido subpilosi, tibiis piceis, anticis antrorsum rufofulvis; tarsis rufescentibus.

Ав оомем lineare, segmentis duobus intermediis, primique margine, rufis.

$V$ ar. $\beta$ abdomine segmentis intermediis ferrugineis, nebulâ obscurâ, piceâ.

This may possibly be the male of the preceding species, but the differences between them are too considerable to take this for granted without further proof. The antennæ of this and other males in this family, seen under a strong magnifier, appear to consist, like those of the male of $A$. long $i$ cornis, \&c. (i), of minute lenses, and probably of the same hexagonal form.

picea. 11. M. atra, glabriuscula; abdomine piceo, nitido, seginentis intermediis basi et utrinque ferrugineis.

(h) Tab. 2. **. a. fig. $9 . \quad$ (i) Tab. 10. **. d. 1. fig. 8. 
MUS. Kirby.

\author{
Long. Corp. Lin. 4.
}

$H a$. Barhamiæ in floribus semel lecta, anno 1799.

\title{
DESCR. Mas.
}

CORPUS atrum, glabriusculum, punctulatum.

CAput. Facies infra antennas tomentoso-argentea. Antennce nigræ, thoracis longitudine, articulis arcuatis.

Truncus. Thorax nitidus. Squamulce nigræ. Alce hyalinæ, iricolorès, apice, nervoque costali interiori, nigris; venis anastomosique flavescentibus. Pedes nigri, pallido-pilosuli.

Ав оомем lineare; nitidissimum, punctulatissimum, nigro-piceum, segmentis duobus intermediis ferrugineis, nebulâ piceâ. Venter basi ferrugineus.

12. M. atra; abdomine subovali, nitidissimo, cin-divisa. gulo ferrugineo; antennis thorace brevioribus.

MUS. D. Marsham, Latham, Trimmer, Lathbury, Kirly. Long. Corp. Lin. 2-3.

$\mathrm{Hal}$. Barhamiæe rarioribus una.

\section{DESCR. Mas.}

CORPUS atrum, piloso-subincanum.

CAPut punctulatum. Os rufescens. Antenna nigræ, thorace breviores, submoniliformes. Facies infra antennas tomentoso-argentea.

Truncus. Thorax punctulatissimus. Squamula nigræ. Ala hyalinæ, iricolores, nervis nigricantibus. 
cantibus. Pedes nigri, pallido-pilosuli ; tarsis omnibus, tibiisque anticis, rufescentibus.

Ав домел breve, subovale, nitidissimum, nigrum; segmentis duobus intermediis, primique margine, ferrugineis.

Var. $\beta$ abclomine segmentis intermediis nebulâ nigricanti.

$\gamma$ abdomine piceo, segmentis intermediis margine et utrinque ferrugineis.

$\delta$ tertiâ ferè parte minor, alarum nervis, excepto costali interiori nigro, testaceis; abdomine segmentis intermediis fasciâ nigricanti. An eadem ?

$\varepsilon$ tertiâ parte minor, abdomine nigro, cingulo angusto rufo.

Its black antennæ not so long as the thorax, and its short abdomen nearly oval, sufficiently distinguish this Melitta from the one just described, which it somewhat resembles. Its head and thorax likewise are not shining, which occasions a striking contrast between them and its lucid abdomen, on which account I have named it divisa. I am not clear that variety $\gamma$ is not a distinct species, but as the only specimen I ever possessed of it was accidentally destroyed, unless I could have given it a more thorough examination, I thought it most adviscable to consider it as a variety. Varieties $\delta$ and :, which are little more than half as big as $\alpha$, may also be distinct, and are perhaps males of M. Geoffrella. 
**. b.

13. M. atra, cinereo-subpubescens; abdominequadriconvexo, segmentis margine albis; pedibus, ${ }^{\text {cincta. }}$ anoque, villoso-pallidis.

\section{MAS。}

Hylaus quad'ricinctus niger, abdomine cylindrico, fasciis quatuor albis.

Fal. Syst. Ent. Em. n. 3.

Lin. Syst. Nat. ed. Gmel. p.2779. Apis, n.96.

Vill. Ent. Eur. 3. Apis, n. 64.

Apis hirsuta; pedibus croceis; abdomine nigro, in cisuris albis.

Geoffr. Hist. Ins. Par. 2, p. 414. n. 13.

Apis hortensis. Fourcroy. Ent. Par. n. 13.

Vill. Ent. Eur. 3. n. 84.

MUS. D. Latham acul. Kirby acul. mas.

Long. Corp. Lin. $4 \frac{1}{2}$.

$\mathrm{Hab}$. prope Londinum rarissima a D. Latham et Mars sham lecta.

DESCR. Acul.

CORPUS atrum, pube cinerascenti.

Ca put. Antennce nigræ, subtus piceæ. Os barbâ flavescenti.

Truncus. Thorax punctulatissimus. Metathorax posticè rotundatus. Squamula piceæ. Alce hyalinæ, apice paulò obscuriores; nervis, excepto costali intcriore nigro, flavescentibus. Pedes nigri; tibiis tarsisque pilis pallidè luteis hirti; digitis omnibus, plantisque posticis; rufescentibus.

ABDomen breve, valde convexum, ovale, punctulis minutissimis, creberrimis, irroratum; VOI. II.

E. segmentis 
segmentis margine latè tomentoso-albis, anticis interruptè. Anus et Venter pallido-hirti. Maris Corpus atrum, pube albidâ canescens. Facies infra antennas villoso-nivea. Nasi apex flavus. Maxilla basi valde dilatatæ $(k)$. Gence subtus concava. Antennce thoracis longitudine, submoniliformes, fulvæ, supra basi fuscæ, scapo toto nigro, articulis extimis pellucidis. Pedes flavi, femoribus nigris, anterioribus quatuor antrorsum fulvo-flavis; tibiis posticis liturâ fuscâ. Aldomen lineare, ano obtuso. $V$ enter anum versus depressus $\int$. concavus.

The male insect now described, appears evidently to be the Hylaus quadricinctus of Fabricius, and, I think, also Apis, n. 13. of Gcoffroy, named by Fourcroy $A$. hortensis, although Villars has introduced them both into his work as distinct insects. The remarkably dilated maxillæ, and concave genæ, distinguish this sex of $M$. quadricincta, from the male of the following species, which it otherwise much resembles: I have never met with either sex of this insect in this part of England; but it has been taken, the aculeate sex twice by Dr. Latham, and the male once by Mr. Marsham, in the neighbourhood of Eondon. I will not take upon me to assert positively, that these are the two sexes of the same individual species; but as they agree together as much as males and females in this family usually do, I thought it better to consider them as such,

(k) Tab. 2.**, b. fig. 10, $t \cdot$, and fig. 11 . 
MELITTA. (**. b.)

than to multiply the species without necessity by making two of them.

14. M. atra, rufescente-pubescens; abdomine seg-rubicunmentis margine albis; tarsis, tibiisque posticis, $d a$. fulvis.

FIG. Apis rulicunda. Christii Hymenopt. p. 190. tab. 16. fig. 10.

Apis flavipes pubescens, atra; thorace, tibiis tarsisque, flavo-villosis; abdomine subcompresso, segmentis margine albido pubescentibus.

Panzer. Fr. Ins. Germ. Init. n.56. tal. 17 ?

MUS. D. Smith, Marsham, Latham, McLeay, Lathlury, Haworth, Trimmer, Sowerby, Kirly.

Long. Corp. Lin. 4.

Hal. Barhamiæ. Sexus aculeatus tempore æstivo et autumnali flores frequentat, pungens acriter. Mas tempore autumnali proveniens, in Curduis et Centaureis præcipuè quærendus.

DESCR. Acul.

CORPUS atrum, pube rufescenti.

Caput. Antenna nigræ. Os barbâ flavescentiaureâ.

Tŕuncus. Thorax ferrugineâ pube, sed haud densâ, tectus. Metathorax posticè rotundatus. Squamule ferrugineæ. Alce hyalinæ, apice obscuriores; nervis, excepto costali interiore nigro, testaceis. Pedes nigri, rufescente-pilosi ; tarsis, tibiisque posticis, fulvis, pilis fulvo-aureis hirtis. Plantıe posteriores liturâ nigricanti. 
AвDOMEN subovale, basi pallido-villosulum, tergo minùs convexo, pilis atris, nisi a latere vix conspicuis, scatenti; segmentis margine tomentoso-niveis, anticis interruptè. Venter pallido-hirtus.

Íar. \& minor, abclomine subcuneiformi, aliàs, ut ovum ovo, a simillima.

Maris Nasi apex Latiumque lutei. Antenna thorace breviores. Squamule nigræ. Pedes sulphurei, femoribus, tibiarumque maculâ subannulari, nigris. Aldomen lincarc, segmentis quatuor anticis margine utrinque tomentosoalbis. Venter anum versus depressus.

Íar. $\beta$ cinereo-subpubescens; tibiis utrinque liturâ nigricanti.

$\gamma$ cinereo-subpubescens; antennis subtus fulvescentibus : abdomine segmentis tribus anticis margine utrinque tomentoso-albis. An eadem ?

The aculeate sex of this species appears to be the Apis rulicunda of Christius, but I am not so certain that it is the Apis favipes of Panzer; his figure agrees with it very well, but his description differs from it in some respects. Though very similar to the preceding species, it is certainly distinct; for its tarsi, the first pair excepted, and its posterior tibia, are not only covered with tawny hair, but their substance is likewise of the same colour; the down of the body also is rufescent, while 
while that of the thorax is ferruginous. In the male, the differences are still more striking. The lip is yellow instead of black, the maxillæ are not dilated at their base $(l)$, the genæ are convex below. The antennæ and thighs are black. Variety $\beta$ of the aculeate sex in nothing differs from $\alpha$, except size, and the form of its abdomen, the base of which is narrower than the apex. It may be the neuter.

15. M. nigro-ænea, nitida; pedibus flavis, fla:ipes.

Iylceus flavipes. Fal. Ent. Syst. Em. n. 11.

Iin. Syst. ed. Gmel. p. 2773. Apis, n. 73.

Vill. Ent. Eur. 3. Apis, n. 80.

Apis nigra, pedibus croceis; abdomine leviter cupreo.

Geofl. Hist. Ins. Par. 2. p. 414. n. 14?

Apis crocipes. Fourcroy. Ent. Par. n. 14?

MIUS. D. Marsham, Lathlury, Trimmer, Haworth, Kirly.

Long. Corp. Lin. $3 \frac{1}{2}$.

Hab. Barhamia. In floribus passim, sed rara admodum.

DESCR. Mas.

CORPUS nigro-æneum, levissimè punctulatum, parvâ pube pallidâ subpubescens.

Caput. Nari apex, Maxilla, itemque Labium, flavi. Antennce thorace ferè longiores, articulis subarcuatis, fuscæ, subtus, exceptis tribus extimis articulis, fulvæ, scapo nigro.

Tru N C U paululùm virens. Thorax lineâ longitudinali intermediâ exaratus. Squamulce piceæ. Alce hyalinæ, iricolores, nervis fuscis. Pedes

(l) Tab. 2. *弚 b. fig, 12.6 , E 3 sulphurei, 
sulphurei, femoribus posticis basi, anterioribus subtus, piceis. Apophyses primi paris articulo secundo subtus flavo.

АвромеN lineare, nitidissimum, ano obtuso, segmentis intermediis basi depressiusculis.

Var. $\beta$ tibiis quatuor posticis strigâ nigricanti, digitorum etiam articulus extimus nigrescit.

I have added a mark of interrogation to the synonym of Geoffroy, because he describes his specimens as having, the abdomen excepted, a black body; in other respects they appear to have been ex actly similar to our insect. $M$. faripes is not very unlike the Apis tumulorum of Linneus. Since the latter insect has been universally mistaken by entomologists for one of the Eucerce of Scopoli and Fabricius, (as I shall have occasion to observe more at large when I come to that family) it will not, I think, be unacceptable if I give a fuller description of it below, taken from the authentic specimens in the Linnean cabinet ; thus future errors concerning it may be prevented $(m)$.

16. M.

(m) $t u$ - M. atra, glabriuscula; antennis corpore brevioribus, subtus mulorum. fulvis; pedibus, maxillisque, flavescentibus.

Apis tumulorum antennis filıformibus longitudine corporis nigri ; pedibus maxillisque flavescentibus.

Lin. Syst. Nat. ed.12. \& Gmel. p.2770. n.2., Fn, Suec. 1685. It. Gotl. 336.

MUS. D. Smith Linnean.

Long. Corp, Lin. 3.

IIal, In Wisingsoæ Sueciæ tumulis sepulchralibus. Lin.

DESCR, 
16. M. nigro-ænea, pallido-subpubescens; abdo-seladonia. mine segmentis margine pallidis.

Apis seladonia hirta, virescens; abdomine segmentis margine albis.

Fal. Suppl. Ent. Syst. Em. p. 276. n. 120.

Apis sulaurata pubescens; tibiis tarsisque ferrugineoflavis.

Ross. Fn. Etrusc. Mant. p, 144. n. 321.

FIG. Apis sulaurata. Panzer.Fn. Ins. Germ. Init. n.56.tal.4.

MUS. D. Marsham, Haworth, Lathbury, Trimmer, Sowerly, Kirly.

Long. Corp. Lin. 3.

Hab. Barhamiæ in floribus tempore vernali, in Belle frequentior.

DESCR. Acul.

CORPUS nigro-æneum, pallido-pubescens.

Caput. Maxilla, itemque Antenna, nigræ.

\section{DESCR. Mas.}

CORPUS atrum, glabriusculum, staturâ fere Melittce flavipedis.

Caput pube pallidâ. Maxillœ, Lalium, et Nasi apex lutei. Antennce thorace longiores, nigræ, subtus fulvæ, articulis tribus extimis fuscis.

Trunces. Sirumulce pallidæ. Ala fuscescentes. Pedes flavi, femoribus anticis basi liturâ fuscâ.

AвDOMEn lineàre, inmaculatum.

M. tumulorum should be placed in this family, next before M. flavipes. I have altered the Linnean nomen specificum, because the terms "antennce longitudine corporis," have led all authors to mistake it for a Eucera. The antennæ, in fact, are only a little longer than the thorax. I have also excluded all the synonyms usually given under this insect, because they belong to another. 
TrunCus. Thorax virescens levissimè punctulatus, lineolis tribus longitudinalibus exaratus. Metalhorax postice truncatus. Squamulce piceæ. Ala hyalinæ, iricolores; nervis, costali interiore cxcepto, rufescentibus. Pedes nigri, pilis lutescentibus hirti. Scopula flavescunt.

AвDoven breve, subovale, tergo pube subincano; segmentis margine, anoque, tomentoso-pallidis. Venter nigricat.

$V a r . \beta$ minor, maxillis basi rufis, antennis subtus, tarsisque, rufescentibus. An Sex. ncut.? $\gamma$ antennis subtus fuscis, abdomine segmentis margine utrinque albicantibus.

With the male of this insect I am not acquainted, without it be $M$. flaripes. Panzer has given a tolerable figure of it, but it has more green than our English specimens.

æata. 17. M. viridi-ænea, nitida; abdomine nigro-ænẹ. MUS. D. Marsham, Haworth, Trimmer, Kirly.

Long. Corp. Lin. $2 \frac{1}{4}-3$.

Hab. Barhamiæe et prope Londinum rara adrnodum.

DESCR. Acul.

CORPUS punctulis levissimè impressis irroratum; parvâ pube pallidâ subincanum.

CAput viridi-æneum. Antenna nigræ basi valde approximatx.

Truncus viridi-æncus. Thorax glabriusculus. Metathorax viridis posticè truncatus, Squar mulce 
mula piceæ. Ala subhyalinæ splendidissimè iricolores; nervis fuscescentibus, anastomosi pallidâ. Pedes nigri, pallido-hirti.

Ав домеN nigro-æneum, nitidum, læve, pallidopubescens, maximè anum versus et ad latera. Maris Corpus atro-virens, albido-pilosulum. $A n$ tennce thorace vix breviores, fuscæ, subtus pallidiores. Nasi apex pallidus. Abdomen lineare, segmentis duobus intermediis basi depressiusculis, tomentoso-subincanis. Tarsi obscurè rufescunt.

18. M. ænea; abdomine nigro; antennis subtusleucopus. fulvis; tarsis albidis.

MUS. Firly.

Long. Corp. Lin. $2 \frac{\pi}{4}$. Hab. In floribus rarissima.

DESCR. Mas.

CORPUS æneum, subpilosum.

CAPUT pube parvâ canescens. Nasus apice pallidus, Antenne nigræ, apice subtus fulvo. Truncus nigro-æneus. Thorax cupreus, punctulatissimus. Metathorax posticè rotundatus. Squamule picex. Alce hyalinæ, coloribus prismaticis splendidè micantes, nervis nigricantibus. Pedes nigri, glabriusculi, tarsis luteo-albis, articulo extimo rufescenti.

A вромеN ovale, pilosulum, segmentis duobus intermediis basi depressiusculis. 
This little insect is somewhat similar to the male of the preceding species, but its antennæ are shorter and paler underneath; its abdomen is black and of a different figure, being proportionally wider, and oval. The tarsi are yellowish white. I do not find either noticed by any author.

Morio. 19. M. ænea; metathorace cærulescenti; abdomine nigro.

\section{MAS.}

Hylaus Morio niger; thorace cærulescente; abdomine atro nitido.

Fal. Ent. Syst. Em. n. 16.

FIG. Coquebert. Ill. Ic. Ins. 25. tab.6. fig. 5. A. E.

MUS. D. Marsham, Latham, $M^{c}$ Leay, Haworth, Lathlury, Sowerly, Trimmer, Kirly.

Long. Corp. Lin. $2 \frac{3}{4}$.

IIal. Barhamiæ, in floribus et terris verticaliter sectis frequens.

DESCR. Acul.

CORPUS pilositate parvâ pallidâ.

CAPU t obscurè viridi-æneum. Antenne basi valdè approximatæ, nigræ, apice subtus fuscæ.

Truncus nigro-æneus. Thorax cupreus, glaber, punctulatissimus. Metathorax atro-cærulescens, posticè rotundatus. Squamula picex. Ala paululùm nigricantes, coloribus prismaticis sub lente pulcherrimæ, nervis nigris, anastomosi testaceâ. Pedes nigri albidohirti.

AbDomen: 


\section{MELITTA. (**, b.)}

АвдомеN ovale, nigrum, nitidissimum, pube parvâ pallidâ, anum versus præcipuè, subincanum.

Maris Corpus atro-virens, interdum cæruleo etiam paululum tinctum. Nasus apice albidus. Antenna thoracis longitudine, apicem versus paulò crassiores, subtus fulvæ. Anastomosis nigra. Digiti obscurè rufescunt. Abdomen lineare, atrum, segmentis duobus intermediis reliquis convexioribus.

The male of this species agrees so well with Fabricius's description of his Hylceus Morio, that I have little doubt of their identity; more especially as the figure given by Coquebert in his elegant Illustratio Iconographica Insectorum, which was taken from the authentic specimen of this insect, agrees very well with ours. The aculeate sex approaches very near to $M$. cerata, but the abdomen is black; and the metathorax atro-cærulescent.

20. M. nigra, nitens; antennis subtus fulvescen-minuta. tibus.

Apis minuta. Schrank. Enum. Ins. Aust. n. 829.

Lin. Syst. Nat. ed. Gmel. p. 2798, n. 150.

Vill. Eut. Eur. 3. n. 45.

FIG. Reanm. tom, 6. Mem. 4. p.95. tal. 9. fig. 1.

MUS. D. Marsham, Latham, M`Leay, Haworth, Lathbury, Trimmer, Sowerly, Kirly.

Long. Corp. Lin, $2 \frac{2}{3}-3$. 
Hab. Barhamiæ. Apud nos, itemque in Galliâ, teste ill. Reaumurio, sub terrâ nidificat hæc species; in Austriâ tamen secundum Schrankium "in foraminibus palorum antiquorum apricorum." In floribus frequens obvia.

DESCR. Acul.

CORPUS nigrum, parcè pilosulum.

Caput. Antennce basi approximatæ, nigræ, subtus fulvescentes.

Truncus. Thorax glaber, nitidus, punctulatus. Metathorax posticè rotundatus. Alce subhyalinæ, iricolores; nervis nigris, anastomosi pallidâ strigâ nigricanti. Pedes nigri, albidohirti.

Aв Dомen ovale, nitidissimum, punctulatissimum punctulis levissimè impressis. Venter hirtus.

Var. $\beta$ tertiâ parte minor, anastomosi nigrâ.

Maris Facies infra antennas tomentoso-alba. Nasus apice albus. Antennce thorace longiores. Aldomen segmentis intermediis basi depressiusculis.

This insect agrees well with Schrank's description of his Apis minuta, but in this country and in France, if Reaumur's synonym be right, it nidificates under-ground; whereas the habitat of his was in old pales: this leads me to doubt, in some degree, whether they are the same.

villosula. 21. M. atra, albido-villosula; abdomine subovato; antennis subtus, tarsisque, rufescentibus. 
MUS. Kirly.

\author{
Long. Corp. Lin. $2 \frac{1}{2}$.
}

Hal. Unde habui non bene memini. Hanc unicam tantum vidi.

DESCR. Mas.

CORPUS atrum, albido-villosulum.

CAPut. Facies ante antennas tomentoso-alba.

Nasus immaculatus. Antenne thorace breviores, nigræ, subtus rufo-fulvæ.

Truncus lævis, villosus. Metathorax posticè rotundatus. Squamula piceæ. Ala hyalinæ, iricolores, nervis nigricantibus, anastomosi strigâ pallidâ. Pedes picei, subhirti ; tarsis rufescentibus.

Авромen ex lineari subovatum, convexum, pilosulum.

This insect is not unlike the male of $M$. minuta, but its antennæ are shorter, the abdomen approaches nearer to the ovate form, and its intermediate segments are not depressed at their base.

22. M. atra, glabriuscula; abdomine nitidissimo. minutissiMUS. D. Marsham, Latham, Trimmer, Lathlury, Kirby,

$$
\text { Long. Corp. Lin. } 2-2 \frac{3}{4} \text {. }
$$

$\mathrm{Hal}$. Barhamiæ in floribus et aggeribus viarum, haud tamen frequens.

DESCR. Acul.

CORPUS atrum, subglabrum.

CAPU T. Antenne nigræ.

Truncus. Thorax punctulis creberrimis levissimè 
simè impressis, irroratus. Metathorax posticè rotundatus. Squamula piceæ. Ala subhyaalinæ, iricolores, nervis nigricantibus. Pedes pallido-hirti.

Ав домем lineare, nitidissimum.

$V a r . \beta$ tarsis, abdominisque segmentis intermediis margine, rufescentibus. An eadem ?

Maris. Corpus albido-villosulum. Nasus apice pallidus. Antennce thorace breviores, subtus fulvæ. Alae apice nigrescentes, coloribus prismaticis splendidissimè micantes. Tarsi obscurè rufescentes. Abdomen ovale, segmentis intermediis basi depressiusculis.

This very diminutive Melitta is less hairy than M. minuta, its abdomen is more shining, and its antennæ are entirely black. The male is the smallest insect of this genus with which I am at present acquainted. It is remarkable for the uncommon splendor and brilliancy with which the prismatic colours adorn its wings,

"As the scite varies in the gazer's hand."

nitidius- 23. M. nigra, glabriuscula; antennis subtus flavis; cula. maxillis, labio, tarsisque, albidis.

MUS. D. Marsham, Haworth, Trimmer, Sowerly, Lathlury, Kirty.

Long. Corp. Lin. $2 \frac{\gamma}{3}-3$.

Hal. Barhamiæ cum præcedentibus, sed frequentior.

DESCR. Mas.

CORPUS nigrum, subglabrum. 
CAPut parvâ pube albidâ incanum. Nasi apex,

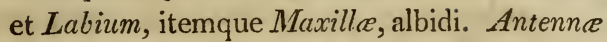
thoracis longitudine, subtus flavæ.

Truncus. Thorax nitidus. Metathorax lævis, posticè rotundatus. Alce subhyalinæ, iricolores, nervis nigris. Pedes nigri, tibiarum geniculis, tarsisque, luteo-albis. Tibice anticæ antrorsum fulvæ.

Авдомем sublineare, nitidum. Venter utrinque, anum versus, fimbriâ pallidâ.

$V$ ar. $\beta$ tibiis totis nigris, tarsis rufescentibus. An eadem?

This species comes very near to the Hylaus annulatus of Panzer $(n)$, but I think it is distinct. It is distinguished from all those that $I$ have before described, not only by its white lip, maxillæ, and tarsi, but also by a singular fringe of pale hair observable upon the underside of the abdomen, near the anus, a little within the margin.

24. M. atra, pallido-villosula; abdomine nigro, lavis, lævi, nitidissimo.

MUS. Kirly. Long. Corp. Lin. $3 \frac{3}{4}$.

Hal. Barhamix semel capta, iterum in Nacton Suffolciæ.

DESCR. Acul.

CORPUS atrum, pallido-subvillosum.

Caput. Antennce nigræ, vix capitis longitudine. Trunces. Thorax obscurus, punctulatus. Me-

(n) Panz, Fn. Ins, Germ. Init. n. 55. tab. 3.

tathorax 
tathorax posticè truncatus, rugulosus. Squamula nigræ. Ala lyyalinæ, iricolores; nervis, costali interiori anastomosique fuscis, exceptis, ferrugineis. Pedes pallido-hirti.

Aв DoMEN ovale, piceo-nigrum, glabrum, lucidum, ano pallido-villoso. Venter hirtus.

punctulata.
25. M. atra, pallido-villosula ; abdomine subpubescenti, punctulato, segmento primo lævi, nitidissimo.

MUS. Kirly.

Hal. Barhamiæ rarissima, semel tantum lecta.

DESCR. Acul.

CORPUS atrum, pube cinerascenti.

Caput. Antenne nigræ, capitis longitudine.

Truncus. Thorax nitidus, punctulatus. Metathorax rugulosus, posticè rotundatus. Squamulce nigræ. Alce subhyalinæ, iricolores, nervis nigris. Pedes pallido-hirti.

АвдомеN sub-ovatum, atrum, nitidum, punctulis minutis, creberrimis, leviter impressis, perseminatum, segmento primo lævi lucido, tribus ultimis pallido-pubescentibus. Venter hirtus.

This species, although very similar to the preceding, is distinguished from it by sevcral peculiarities, the most striking of which is its punctulate abdomen. These punctula are slightly impressed, and not visible without a magnifier. 


$$
\text { MELITTA. (**. b.) }
$$

26. M. nigra, griseo-subpubescens; abdominemalachusubtomentoso.

MUS. D. Trimmer, Kirly.

Long. Corp. Lin. 4.

IIal. Brentfordiæ prope Londinum, a D.J. Trimmer bis capta.

DESCR. Acul.

CORPUS nigrum, pube grisescenti.

CAPut obscurum. Antennce nigræ.

Truncus. Thorax obscurus, punctulatus. Metathorax posticè rotundatus. Squamulce nigræ. Alce subhyalinæ, iricolores, apice obscuriores; nervis, costali interiori fusco excepto, flavis. Pedes flavescente-hirti. Scopule rufæ.

Ав домеN ovale, pilis grisescentibus subtomentosum, sed haud ita densè ut non transluceat nigredo corporis. Segmentorum margines, et anus, pilis decumbentibus, subflavis, confertius hirti. Venter anum versus per fascias longiùs villosus.

The abdomen of this species is not so narrow, $d$ is also much more downy, than the same part M. punctulata.

7. M. nigra; antennis thorace longioribus, ful-fulvicorvescentibus; abdomine nitido, segmentis in- ${ }^{\text {nis. }}$ termediis basi albis.

'is. Kirly.

Long. Corp. Lin. $2 \frac{r}{3}$,

$H a b$. in Angliâ rarissima.

it. Ir. F DESCR. 
DESCR. Mas.

CORPUS nigrum, pube haud densâ subincanum.

CA P U T. Facies infra antennas tomentoso-incana. Nasus apice albidus. Antenna thorace longiores, rufo-fulvæ, supra saturatiores, scapo nigro.

Truncus obscurus. Metathorax posticè truncatus. Squamula piceæ. Ala subhyalinæ, iricolores, nervis nigris. Pedes nigri, glabriusculi, tarsis flavescentibus, articulo extimo ferrugineo. Tilice quatuor posteriores basi extrinsecus flavæ, anteriores antrorsum fulvescunt.

AвDOMEN sublineare, nigrum, nitidissimum, glabrum, segmentis intermediis basi depressiusculis et utrinque tomentoso-albis. Venter glaber, ano pilosulo.

The antennæ of this insect are nearly, if not altogether, as long as those of $M$. tumulorum; it is, however, extremely distinct from that and every other described insect, of which I have any knowledge.

fulvo- 28. M. nigra, rufescente-pubescens; abdomine cincta. subtomentoso; segmentis margine fulvis, intermediis basi utrinque pallidis.

\section{ACUL.}

Apis nitida nigra, incisuris abdominis nitidi, pedibusque, luteo-cinereis.

Miill. Zool. Dan. n. 1619. 


$$
\text { MELITTA. (**. b.) }
$$

MAS. $\varepsilon$.

Apis licincta nigra; ore, cingulisque duobus abdominis, albis.

Sclirank. Enum. Ins. Austr. n. 826.

Lin. Syst. Nat. edl. Gmel. p. 2787.n. 140.

Vill. Eut. Eur. 3. n. 4 i.

MUS. D. Marsham, Latham, $M^{\circ}$ Leay, Lathbury, Haworth, Sowerly, Trimmer, Kirly.

Long. Corp. Lin. 3-4 $\frac{\mathrm{I}}{2}$.

Hab. Barhamix et alibi frequens. In capitula Plantaginis lanceolate tempore vespertino agglomerant mares, ibique dormitant.

\section{DESCR. Acul.}

CORPUS nigrum, rufescente- pubescens.

Caput obscurum, hirtum satis. Antenne nigræ. Truncus obscurus. Thorax subpubescens, punctulatissimus. Metathorax rugulosus, posticè truncatus. Squamulce piceæ. Alre subhyalinæ, apice obscuriores ; nervis, costali interiori nigro excepto, ferrugineis. Pedes nigri rufescente-hirti. Tilice posticæ scopâ flavescenti. Scopulc fulvo-aureæ.

АвฉомеN ovale, nitidissimum, subpubescens, segmentis margine pallidè fulvis, pilis flavescentibus densis ciliatis, intermediis duobus basi utrinque tomentoso-pallidis. Ani pili fulvescunt.

Far. $\beta$ minor, abdominis segmentis intermediis basi albidis.

$\gamma$ minor, atra; abdominis segmentis margine obscurè̀ rufis, vix ciliatis. In hâc varietate alx sunt testacex. An eadem ?

$$
\text { F } 2
$$

$\delta$ tertiâ 
MELITTA. (**. b.)

$\delta$ tertiâ ferè parte minor, abdomine angustiori, alias $\beta$ similis.

Maris Corpus pube subcinereâ. Facies ante antennas tomentoso-argentea. Nasus porrectus, apice luteus. Labium palliclun. Ántenna thorace breviores. Thoracis pili subrufi. Squamulce extrorsum pallidæ. Ala subiricolores. Pedes pilosuli; tibiis quatuor posticis basi et apice, anticis lineâ longitudinali, tarsisque, luteis ; digitorum articulis extimis rufis. $A b$ domen lineare, ventre planiusculo.

Var. $\beta$ labio nigro; alarum nervis nigricantibus, tibiis primi et secundi paris tantummodo basi albis; abdomine segmentis margine inmaculatis.

$\gamma$ labio nigro; tibiis immaculatis, digitis ferrugineis.

$\delta$ minor, corpore atro, albescente-subvilloso, labio nigro. Alias a similis.

$\varepsilon$ tertiâ ferè parte minor, abdominis segmentis intermediis basi albis.

Taricty $\gamma$ of the aculeate sex of this insect, and variety $\delta$ of the male, may be distinct, but the differences appeared to me not striking enough to warrant my considering them as the sexes of a separate species. One of the varieties of the aculeate, I take to be the Apis nitida of the Zoologia Danica; but, since, after Fourcroy, I have given this mame to another insect of this genus, I have distinguished this by another. Variety $\varepsilon$ of the male, 
is, I think, evidently the Apis bicincta of Schrank, but as his name harmonizes well with this variety only, I have not adopted it. Whether the Hylceus similis of Fabricius (o) may not belong to a variety of this insect, I am not certain; but as I have as yet found none that will quite agree'with his definition, I have not referred to it. Twice in the year 1799, in the month of August, in the evening, I found the males of this species, in considerable quantities, taking their repose upon the heads of the Ribwort Plantain.

29. M. atra, albido-subvillosa; abdomine segmen-albipes.

tis intermediis rufis, fasciâ, punctisque lateralibus, nigris; labio flavo.

Hylceus albipes fuscus; abdomine medio rufo; tibiis albis.

Fab. Ent. Syst. Em. n. 13 ?

Lin. Syst. Nat. ed. Gmel. 1).2779. Apis, n. 98.

Vill. Ent. Eur. 3. n. 65.

Ross. Fn. Etrusc. Mantiss. n. 320.

FIG. Harris. Erp. tab. 39. fig. 19.

Panwer. Fn. Ins. Germ. Init. n.7. tab. 15.

MUS. D. Marsham, Sowerly, Kirby.

Long. Corp. Lin. 4.

HaT. Barhamix in floribus passim sed rariùs.

DESCR. Mas.

CORPUS atrum, pube albescenti subincanum.

CA P t obscurum. Nasus porrectus apice e fulvo flavescenti. Labium flavum. Maxilla basi

(o) Fab. Ent. Syst. Em, n. 14.

F 3

nigræ, 
MELITTA. (* * b.)

nigræ, dein flavæ, apice ferruginex. Facies ante antennas tomentoso-argentea. V'ertex cinerascenti-pilosulus. Antennce thoracem subæquantes, fuscæ, supra basi nigræ.

Truxcus. Thorax obscurus, punctulatus, pube parvâ cinerascenti. Metathorax posticè rotundatus. Squamula, itemque Tuberculorum vertex, pallidæ. Alæ hyalinæ, splendidè iricolores, nervis nigricantibus. Pedes luteoalbi, femoribus, tibiarumque liturâ subannulari, nigris.

AвDOMEN sublineare, anum versus latius, glabrum, nitidum, basi nigrum, dein rufum, fasciis cluabus abbreviatis, dorsalibus, punctisque quatuor lateralibus, anoque nigris. Fenter rufus ano nigricanti. Obs. Segmenta postica margine olscurè rufescunt.

$V a r . \beta$ antennis totis nigris.

$\gamma$ maxillis nigris; tibiis tantùm basi luteis. $\delta$ maxillis nigris, alarum nervis testaceis; abdomine supra nigro segmentis margine late rufis, intermediis basi tomentoso-albis. An eadem ?

It is not without some hesitation that I give this as the Hylaus allipes of Fabricius; but, as he says of his, "variat interdum segmento secundo tertioque rufis, maculâ mediâ nigrâ," this variety may probably be our insect. The tibix, in all that I have had an opportunity of examining, have either a blackish 
blackish cloud, which nearly surrounds their middle, or they are black with a yellowish base, as is the case with variety $\gamma$. Panzer's figure exactly resembles the insect here described, except that it omits the two black dots which distinguish each side of the abdomen; and, in his description, he

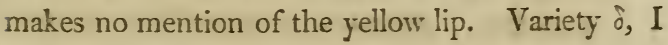
suspect, may be a distinct species.

30. M. atra, cinereo-subvillosa; abdomine seg-al.domimentis anticis rufis, maculà mediâ, punctisque ${ }^{\text {nalis. }}$ lateralibus, nigris.

FIG. Hyløus aldominalis abdomine seçmentis primo, secundo et tertio, rufis, maculà mediâ nigrâ, reliquis nigris. -Panzer. Fn. Ins. Germ. Init. n. 53, tal. 19.

MUS. D. Marsham, Latham, Lathlury, Haw orth, Trimmer, Kirly. Long. Corp. Lin. $4 \frac{1}{2}$.

Hat. Barhamiæ cum præcedente in tloribus passim obvia.

DESCR. Mas.

CORPUS atrum, pube cinerascenti.

CAPUT obscurum. Facies infra antennas tomertoso-argentea. Nasus porrectus, apice flavus. Labium atrum. Antenne nigræ, thoracem subæquantes.

Truncus obscurus, punctulatus. Metathorax posticè subtruncatus. Squamulce pallidæ. Alce hyalinæ, apice paulò obscuriores, iricolores; nervis, costali interiori nigro excepto, ferrugineis. Tilice posticæ basi, Plantreque, luteo-albæ. Digiti rufescunt. 
ABDONEN sublineare, apicem versus latius, nitidum, glabrum; segmento primo basi nigro, margine late, sccundoque, rufis maculâ mediâ trapeziformi nigra, tertio nigro lateribus rufis, ultimis nigris. Serrmenta duo intermedia utrinque puncto nigro, itemque basi tomentoso-alba. Fenter basi rufus liturâ semicirculari nigricante.

Var. $\beta$ alarum nervis nigricantibus; tibiis ịmmaculatis, plantis rufis basi albidis; abdomine segmentis margine rufis, secundo rufo maculâ nagnầ clorsali, punctisque duobus latcralibus, nigris.

This insect is nearly related to the precerling species, but I think, with Panzer, we may venture to separate them. He, indeed, supposes that they may be different sexes of the same individual, but in this he is mistaken, as they are both certainly males, the female in this family being of a very different form. M. aldominalis is larger than $M$. allipes, its labium and maxillie are black, the tibix also are black, the last pair only having a white ring at their base. The spots on the red segments of the abdomen are of a different form, and at the base of the three intermediate ones is a small patch of white decumbent hairs. I'anzer's figure varies somewhat from our specimens, the margin of the intermediate segments of the abdomen in that being yellow, as well as the joints of the legs, which is not the case with ours. 
31. M. atra, glabriuscula; abdomine nitidissimo, olovata. obovato, segmentis basi albis.

MUS. Kirly. Long. Corp. Lin. 4. Hab. Barhamiæ, semel lecta.

DESCR. Acul.

CORPUS atrum, subglabrum.

CAPUT pilositate parvâ grisescenti respersum. Antenna nigræ, subtus piceæ.

Truncus grisescente-pilosulus. Thorax glaber, punctulatissimus. Metathorax posticè truncatus. Squamula piceæ. Alce testaceæ, nervo costali interiore nigro. Pedes griseo-hirti. Tilice posticæ scopâ, densâ admodum, grisescenti. Digiti ferruginei. Scopula flavæ, subauratæ.

Авдомen ex cuneiformi obovatum, læve, nitidissimum, segmentis tribus intermediis basi tomentoso-niveis. Anus griseo-pilosulus. Venter grisescente-hirtus.

32. M. atra, rufo-subpubescens; thorace ferrugi-lavigata. neo; abdomine nitidissimo, segmentis intermediis basi pallescentibus.

MUS. D. Marsham, Latham, Trimmer, Lathbury, Kirly, Long. Corp, Lin. 4.

Hal. Barhamiæ e rarioribus una.

DESCR. Acul.

CORPUS atrum, pube rufescenti.

CAPU t. Antenna nigra. 
MELITTA. (**. b.)

Truncus. Thorax nitidus, punctatus, ferru. gineo pubescens. Metathorax posticè truncatus, utrinque denticulo armatus. Squamula piceæ. Alce hyalinæ, subiricolores, apice obscuriores; nervis, costali interiore nigro excepto, ferrugineis. Pedes rufo-hirti: $\mathrm{Fe}$ mora ultimi paris lanata. Tilice postica scopâ flavescente-aureâ.

Ав DOMEN ovatum, nitidissimè lævigatum, basi rufo-subvillosum, segmentis margine crassiusculis, intermediis tribus basi tomentosoluteo-pallidis. Anus et Venter pallido-hirti.

This and the remaining species of this family, are distinguished from the rest by having the margin of the dorsal segments of the abdomen much thicker.

leucozo- 33. NI. atra, cinereo-pubescens; abdomine segzia. mentis intermediis basi albis.

Apis leucozonia nigra; abdominis segmentis basi albis. Schrank. Enum. Ins. Austr. n.819.

Lin. Syst. N'at. ed. Gmel. p. 2787. n. 137.

Vill. Ent. Eur. 3. n. 34.

Ross. Fn. Etrusc, Mantiss. n. 319.

MUS. D. Marsham, Smith, Latham, Haworth, Lathlury, $M^{\circ}$ Leay, Trimmer, Kirly.

Long. Corp. Lin. 4-4 $\frac{\mathrm{r}}{7}$.

Hab. Barhamiæ, flores frequentans.

DESCR. Acul.

CORPUS atrum, cinereo-pubescens.

Caput. 
Caput. Antennce nigræ. Lingua apice acuminata.

Truncus subglobosus. Thorax punctulatus. Metathorax posticè truncatus. Squamulce atræ. Alce hyalinæ, subiricolores; nervis, costali interiore anastomosique nigris exceptis, ferrugineiș. Pedes nigri, cinereo-hirti. Scopula fulvescunt. Digiti articulis extimis ferrugineis.

Ав домеN, subovale, aterrimum, nitidiusculum, punctulis levissimè impressis perseminatum, basi cincreo-subpubescens, segmentis margine crassiusculis, intermediis tribus basi tomentoso-niveis. Anus et $V$ enter cinereo-hirti.

Maris Corpus albescenti-incanum. Antennce thorace breviores. Facies infra antennas tomentoso-argentea. Nasus apice albidus. Alce valdè diaphanæ, iricolores. Plantæe quatuor posticæ albæ. Digitorum articulus extimus rufus, reliqui nigri. Abdomen sublineare, convexum, pilosulum.

This species a good deal resembles $M$. lavigata, but it is of a black still deeper. The pubescence of its whole body is cinereous. Its abdomen is punctulated, and the base of the intermediate segments are covered with decumbent hairs as white as snow. The wings of the male are beautifully transparent, not having their brightness obscured by the least shade of colour; at the same time, when the light falls upon them in a certain direction, they exhibit the hues of the rainbow. I think the aculeate 
aculeate is beyond a doubt the Apis leucczonia of Sclırank.

xanthopus34. M. nigra, rufo-pubescens; thorace ferrigineo; abdomine segmentis utrinque basi pallidis; pedibus posticis testaceis.

FIG. Apis maxillosa. Christii Hymenopt. p. 179. tab. 14. fig. 7?

MUS. Mas. MIarsham, Haworth, Lathlury. Acul. et Mas. Trimmer, Kirlyy.

Long. Corp. Lin. 5.

Hab. Barbamiæ. Tempore autumnali mas fores frequentat, sed rarus admodum. Femina bis capta Aprile exeunti 1800 ; semel etiam a D.Trimmer accepi.

DESCR. Acul.

CORPUS nigrum, obscurum, pube rufa.

Caput. Maxilla forcipatæ. Antennce nigra, capite ferè longiores.

Truncus supra pube ferrugineâ. Thorax punctatus, rariùs villosus. Metathorax posticè rotundatus. Squamule piceæ. Alce subhyalinæ, apice obscuriores; nervis, costali interiori nigro excepto, testaccis. Pedes nigri, rufo-hirti, tarsis quatuor, tibiisque, posticis, rufo-testaceis. Scopa, Scopulcque fulvo-aureæ.

Ав оомеN ovatum, atrum, nitidum, punctulatissimum, basi rufo-villosum; segmentis margine crassiusculis, intermediis tribus basi utrinque tomentoso-pallidis. Anus et Venter pallido-hirti. 
Var. $\beta$ segmentis intermediis per totam basin tomentoso-pallidis; alarum nervis ferrugineis; plantis quatuor posticis nigricantibus. Maris Corpus pube cinerascenti. Antenne thorace breviores subtus piceæ. Nasi apex maculâ obscurâ albidâ notatur. Maxilla haud protensæ. Thorax pube subrufâ. Alce iricolores. Abdomen subovale, segmentis tribus intermediis basi tomentoso-albidis.

$V a r . \beta$ thoracis pube cinerascenti, plantis posticis quatuor albis.

This is one of the largest species of this family that we have in England, it may always be distinguished from all the rest by the colour of the posterior legs, which, the thighs excepted, are always red, and covered with reddish hair. I take this to be the insect which Christius has figured as the Apis maxillosa of Linneus, but it is certainly a widely different species. If I am right in my rcference to him, the thorax of his specimen had lost all its ferruginous hair, an accident which not unfiequently happens to these insects. His Apis emarginata, likewise, very much resembles our insect $(p)$, it may possibly be the male.

35. M. atra, cinereo-subpubescens; abdomine sub-quadrinoincano, segmentis duobus intermediis basi ${ }^{\text {tata. }}$ utrinque albis.

MUS. D. Marsham, LaLham, McLcay, Trimmer, Lathlury, Haciorth, Sou'erly, Kirly.

(i) Tab. 15, fig. 2. p. 183.

Long. 
HIal. Barhamiz ternpore vernali in floribus Oxyacantha freq̨uens.

DESCR. Acul.

CORPUS atrum, pube parvâ cinerascenti subincanum.

Caput. Antennce nigræ, capitis longitudine. Truncus obscurus. Thorax punctulatus. Metathorax posticè rotundatus. Squamula nigræ. Alce subhyalinæ, subiricolores; nervis, costali interiori nigro excepto, testaceis. Pedes cinereo-hirti. Scopula fulvæ.

Aв DомеN ovale, punctulatissimum, punctulis levissimè impressis, anticè nitidum, glabrum, posticè tomentoso-incanum, sed non ita densè ut non transluceat nigredo corporis; segmentis margine crassiusculis, intermediis duobus basi utrinque tomentoso-niveis.

Obs. In recentiorilus fulvescit anus.

Maris Antenne thorace breviores. Facies infra antennas tomentoso-nivea. Nasus apice albidus. Tarsi, tibiarumque apex, luteo-albi, digitorum articulis extimis rufescentibus. $A b$ domen lineare.

This minute species, although similar to M. leucozonia, must not be confounded with it. The apex of its tongue is not acuminate in either sex, a circumstance which strongly marks both the sexes of that insect. The base of two only of the intermediate seginents of the abdomen are white, and the 
three last are frosted by a thin coating of decumbent down. All the tarsi of the male are whitish.

36. M. atra, albido-subpubescens; abdomine seg-lugullris. mentis intermediis basi utrinque, plantisque, albis; antennis thorace longioribus.

MUS. Kirly.

Long. Corp. Lin. 3.

Hab. Barhamiæ, semel capta.

DESCR. Mas.

CORPUS atrum, pube albicanti.

CApU T. Facies infra antennas tomentoso-nivea. Nasus porrectus, immaculatus. Antennce nigræ, thorace longiores.

Truncus. Thorax obscurus, punctulatissimus, pube cinereâ. Metathorax posticè truncatus. Squamulce pallidæ. Alce hyalinæ, iricolores; nervis testaceis, costali interiore nigro. Pedes atri, albido-pilosuli, tibiis posticis basi, plantisque omnibus, albis; digitis pallidè rufis. Palmce etiam rufescunt.

Ав оомел lineare, aterrimum, nitidum, subglabrum; segmentis margine crassiusculis, inter.. mediis tribus basi utrinque tomentoso-niveis.

I know only the male of this species, which much resembles the same sex of the preceding. But its antennæ are proportionably longer; its nasus has no white spot, a remarkable circumstance in this family; its posterior tibiæ are white at their base; and its abdomen has six white spots, in that particular resembling the species I am next to describe. 
sexnotata.37. M. aterrima, pube incanâ; abdomine segmentis tribus intermediis basi utrinque albis; alis apice nigris.

FIG. Acul. Tab. 15. fig. 7. Mas. ilid. fig.8.

MIUS. D. Marsham, Latham, $M^{`}$ Leay, Lathbury, Haworth, Trimmer, Sowerly, Kirly.

Long. Corp. Lin. 5.

Hal. Barhamiæ, in floribus tempore autumnali haud frequens.

DESCR. Acul.

CORPUS. Corpus aterrimum, pube albescenti incanum.

Caput obscurum. Antenna nigræ, capitis longitudine.

Truncus obscurus, villosus admodum. Metathorax posticè rotundatus. Squamula magnæ, atræ. Alce subhyalinæ, apice nervisque crassioribus, nigris; venis, nervo costali exteriori, anastomosique, rufo-piceis. Pedes albido-hirti. Tilice posticæ scopâ versicolori, sub luce ta-

- men argenteâ. Scopulce flavescunt.

AвDOMEN ovatum, nitidum, basi albescentisubvillosum; segmentis margine crassiusculis, intermediis tribus basi utrinque tomentosoniveis. Venter albido-hirtus.

Maris Antenna nigræ, thorace breviores. Facies piloso-albicans. Nasi apex obscurè pallidus. Aldomen sublineare, anum versus paulò latius. 
**. c。

38. M. atra, glabriuscula; abdomine nigro, cingulo Latham antico, ano, scopâque, rufis.

MUS. D. Latham.

Long. Corp. Lin. 8.

Hab. in Angliâ, a D. Latham ornithologo præstantissimo et jure celeberrimo, in entomologiâ etiam apprimè docto, mihi transmissa; in cujus honorem nomen imposui.

DESCR. Acul.

CORPUS atrum, glabriusculum.

Carut. Facies infra antennas, cinereo-villosa. Antennce nigræ, subtus piceæ. Maxille apice dilatatæ.

Truncus punctulatus. Squanule ferrugineæ. Alce testaceæ, apice, nervisque, nigricantibus. Pedes nigri, fulvo-hirti, tibiis posticis scopâ rufâ. Flocculus rufescens.

Ав домем ovale, depressum, glabriusculum, nigrum; segmento primo margine, secundoque, rufis. Ani Fimbria densa, ferruginea. Segmentum antepenultimum ciliâ marginali pallidâ. Venter ferrugineo-hirtus, segmento secundo rufo.

This is the largest English Melitta I have ever seen.

39. M. atra, cinereo-subvillosa; abdomine cingulo Rosa. antico rufo; scopâ versicolori.

FIG. Andrena Rosa thorace pubescente; abdomine nigro,

YOL. II,

G

nitido, 
MELITTA. (**. c.)

nitido, segmento secundo, tertioque, rufis, maculä mediâ, nigra.

Panzer. Fn. Ins. Germ. Init. n. 74. fig. 10.

Apis cingulata. Christii Hymenopt. p. 187. tab. 15. fig. 10?

MUS. D. Marsham, Smith, Latham Trimmer, Kirby.

Long. Corp. Lin. 6.

Hab. in Angliâ, capta sæpius prope Londinum, semel

in Insulâ Eliensi; $\beta$ in Cambriâ Aprile medio a

D. Goodenough.

DESCR. Acul.

CORPUS atrum, pube cinereâ.

CAput villosum, latum. Antenne nigræ. Maxilla basi denticulo armatæ.

Truncus. Thorax pube haud densâ. Squamula piceæ. Alce testaceæ. Pedes pilis brevibus nigricantibus scatent. Femora lanâ pallidâ. Tilice posticæ scopâ pro situ nunc nigricanti, nunc pallescenti, revera pili superiores nigri sunt, inferiores cinerei. Digiti ferruginei. Flocculus obsoletus. Scopula fuscæ.

АвDOMEN subovatum, glabrum, basi nigrum nigredine trilobâ, segmento primo margine, proximisque duobus, rufis. Ani Fimlria sordidè pallida. Venter pallido-hirtus, segmento secundo rufo.

$V a r . \beta$ alis hyalinis, apice fuscescentibus; abdo.. mine segmento tertio nigro, lateribus rufis; ani fimbriâ nigricanti.

$\gamma$ alis, nervo costali interiore piceo; abdomine segmento secundo rufo maculâ mediâ nigra, tertio nigro lateribus rufis.

$\delta$ antennis 
MELitTa. (**. c.)

$\delta$ antennis subtus rufo-piceis; maxillis basi inermibus; abdomine segmento primo margine latè rufo, secundo rufo fascià nigricanti; alis ut in præcedente; ventre segmento primo margine rufo, reliquis nigris. $\varepsilon$ minor, antennis subtus rufo-piceis ; maxillis basi inermibus; abdomine segmentis margine, secundique lateribus, rufis; ano fimbriâ fuscâ. Obs. In hâc varietate color rufus marginum segmentorum abdominalium interdum valde olscurus et tantùm non evanidus.

Maris Corpus densiùs villosum. Caput trunco majus. Antenna capite longiores. Maxillce forcipatæ, apice acutæ. Pedes cinereo-hirti. Abdomen piceo-nigrum, ex lanceolato ovatum, pilosulum, segmento primo margine rufo, secundo rufo fasciâ piceâ. Venter basi rufus.

Variety $\alpha$ of this species, somewhat resembles M. Lathainana, but it is nevertheless very distinct. Not to mention the difference of their size, which is very considerable, $M$. Rose wants the ferruginous scopa and fimbria of the former. In the present family, the colour of the scopa affords an excellent character for the definition of species, as it is not subject to variation. I have defined it, upon the present occasion, and in several other instances, by the term versicolor, because, although the hairs of its upper side are of a different colour from those of

$$
\text { G } 2
$$


the under, yet, in certain lights, they appear wholly either of one colour or the other.

Had I known no other varieties than $\alpha$ and a of M. Rosa, I should, most probably, have regardect them as very distinct species; but by means of the intermediate ones, which exhibit the gradual change of the ablominal colours, their identity seems pretty clearly established; although I am still not without a suspicion, from the absence of the very minute tooth at the base of the maxillæ, which distinguishes $\alpha, f$, and $\gamma$, whether $\delta$ and $\varepsilon$ may not be more than varietics; unless we may suppose this to be a sexual distinction, and look upon $\alpha, \beta$, and $\gamma$ as females, and $\delta$ and $\varepsilon$ as neuters.

The abdomen of $a$ is distinguished by a red belt, which occupics the margin of the first, and the whole of the second and third segments: in $\beta$, the third segment is red only on the sides; in $\gamma$, the second also has a black spot in the middle; in $\delta$, this spot becomes a fascia, extending nearly from side to sicle; and in s, only the margin of the segments is red, and that sometimes very faintly. 'Throwgh all these varicties the colour of the scopa remins the same.

Panzer's Apis Rosit is criclently one of the varicties of our insect, but his description and figure are at variance. The former says, "aldominesegmentis secundo, tertio, quandoque etiam primo postici, muls;" whereas, in the latter, the margin only 
only of the first, and the whole of the second segment, are red, the latter having an intermediate blackish spot. This figure represents our variety $\gamma$.

Variety $\delta$ appears to be the insect which Christius has figured as the Nomada cingulata of Fabricius.

I have never met with any of the numerous varieties of this insect in my own neighbourhood, but it seems common enough, $\alpha$ and $\beta$ excepted, in the vicinity of London.

40. M. atra, cinereo-villosa; ablomine nigro, cin-znalis. gulo rufo; pedibus posticis piceis.

MIUS. D. Trimmer, Kirby.

$$
\text { Long. Corp. Lin. } 4 \frac{2}{3} \text {. }
$$

Hul. In Angliâ, a D. H. Trimmer propè Londinum bis capta.

\section{DESCR. Mas.}

CORPUS atrum, cinereo-villosum.

Caput. Antenne nigræ, thoracis longitudine articulis subarcuatis. Mraxilla basi dente obsoleto.

Truncus. Squamule picex. Alce subtestacer, apice obscuriores, nervo costali interiore nigm. Pedes nigri, cinereo-hirti, posticis piceis. Thi giti ferruginei.

AвDOMEN lanceolatum, pilosulum, nigro-piceum; segmento secundo apice, tertio basi ct apice obscurè, rufis; segmenta postica ciliti marginali, anoque, albidis. Tenter cinercohirtus, segmentis anticis rufo-fulvis. 
MELITTA. (**,c)

This, at first sight, resembles not a little the male of the preceding specics; but its antennæ are much longer, and the abdomen is of different form. The head also is smaller, and the maxillæ not so long.

cingulata.41. M. nigra, cincreo-subpubescens; abdomine glabriusculo, cingulo ferrugineo utrinque puncto nigro.

\section{ACUL.}

Nomada cingulata cinereo-villosa; abdomine glabro nigro, segmento secundo tertioque ferrugineis.

Fab. Ent. Syst. Em. n. 15.

Vill. Ent. Eur. 3. Apis, n. 70.

Ross. Mantiss. $n .326$.

Apis Suecica. Lin. Syst. Nat. ed. Gmel. p. 2794. n. 200.

FIG. Apis sphegoides atra, cinereo-pubescens; abdomine ovato, segmentis secundo et tertio rufis, pedibus flavis.

Panzer. Fn. Ins. Germ. Init. n.56. tal. 24.

MUS. D. Smith, Marsham, Trimmer, Lathlury, Kirly.

MAS.

Andrena laliata villosa, nigra; abdominis segmento secundo tertioque rufis; labio albo.

Fal. Ent. Syst. Em. n.5.

Lin. Syst. N'at. ed. Gneel. Apis, p. 2793. n. 192.

Vill. Ent. Eur. 3. n. 71.

FIG. Apis allilabris atra, pubescens; labio niveo albido barbato, punctis duobus nigris; abdomine ovato, segmentis secundo et tertio rufis.

Panzer. Fn. Ins. Germ. Init. n. 56. tab. 23.

MUS. D. Marsham, Trimmer, Hill, Kirby.

Long. Corp. Lin. $3 \frac{3}{4}-4 \frac{1}{4}$.

Hal. Barhamix. Femina in floribus Ranunculi bullosi Maio mense sæpius capta. Mas tempore autumnali provenit rarus admodum.

DESCR. 


\section{MELITTA. (**. c.)}

DESCR. Acul.

CORPUS nigrum, pube cinereâ.

Caput. Antennce subtus rufx.

Truncus. Squamule rufescentes. Ale subhyalinæ apice nigricantes, nervis nigris. Pedes cinereo-hirti, scopâ cinerascenti. Scopula flavescunt. Flocculus pallidus.

Ав DомеN ovatum, glabriusculum, punctulatissimum, nigrum; segmentis intermediis duobus ferrugineis, secundo utrinque puncto nigro. Ani Fimbria cinerascens. Venter cinereo-hirtus, basi rufus.

Maris Corpus albido-villosum. Facies anticè alba, barbâ argenteâ. Nasus punctulis duobus nigris. Labium atrum. Antenne sensim crassiores, capite longiores, subtus fulvæ. Thorax pube cinerascenti. Squamula piceæ. Abdomen sublineare, convexum, pilosulum; segmentis intermediis duobus rufis, secundo utrinque puncto nigricanti.

It is without any hesitation that I give the two sexes of this insect as the Nomada cingulata, and Andrena labiata of Fabricius, since they exactly answer his description, except only that he does not take notice of the minute blackish spot on each side of the second abdominal segment, a circumstance easily overlooked. Panzer's figure, also, and description of his Apis Sphegoides and alvilabris, accurately represent them, only he describes the hair of the legs of the former as yellow, which 
is not the case with our specimens. It is remarkable that both Fabricius and Panzer, in this instance, apply the term labium, not to the tongue, which is the labium of the Fabrician system, nor yet to the Linnean labium, but to the anterior part of the face. The male agrees with the female in all such circumstances as the sexes usually possess in common, even so far as the black dot on cach side of the second segment of the abdomen : a white or yeilow nose is no uncommon characteristic of the male.

Schrank-42. M. nigra, cinereo-subvillosa; thorace rufescenella. ti; abdomine cingulo rufo, segmentis posticis flavo-ciliatis.

Apis Cetii nigra, abdomine ferrugineo, segmentorum apicibus flavis.

Schrank. Enum. Ins. Austr. n. 818.

Lin. Syst. Nat. ed. Gmcl. p. 2786. n. 136.

Vill. Ent. Eur. 3. n. 33.

Andrena marginata thorace pubescente, abdomine ferrugineo, segmentorum marginibus cinereis, segmento primo atro.

Fal. Ent. Syst. Em. n. 10.

Vill. Ent. Eur. 3. Apis, n. 72.

Apis marginella. Lin. Syst. ed. Gmel. p.2793. n.191.

EIG. Andrena marginata. Panzer. Fn. Ins. Germ. Init. n. 72. tab. 15.

MUS. D. Marsham, Smith, Trimmer, Kirly.

Long. Corp. Lin. 4.

Hal. Barhamix, tempore autumnali in floribus hat,d frequens.

DESCR, 
DESCR. Acul.

CORPUS nigrum, cinereo-villosum.

Caput. Linguce apex elongatus. Antennce fuscæ, scapo nigro. Vertex pilis flavescentibus. Facies ponè antennas maculâ sericeo-pallidâ, nisi a latere et sub lente, vix conspicuâ, notanda. Nasus valde convexus.

Truncus. Thorax pube rufescenti tectus. Squamulce nigræ. Alce subhyalinæ, apice nervisque nigris. Pedes cinereo-hirti. Tibice posticæ scopâ supra nigrâ, subtus pallidâ, certo situ versicolori. Scopula fulvæ, Digiti ferruginei.

AвDомen subovale, tomentoso-fulvum, tergo depressiusculo; segmento primo nitido, nigro, villoso, apice, proximisque duobus, pallide rufis, secundo utrinque puncto nigro, reliquis nigricantibus, apicibus pilis fulvo-flavis ciliatis. Ani Fimbria fulvo-aurea. Venter convexus, rufus, apice piceus, segmentis pallido longiùs ciliatis.

Obs. Abdominis segmenta ultima e ferrugineo nigricant.

$V^{\top}$ ar. $\beta$ antennis totis nigris; abdomine segmento secundo immaculato, tertio lineâ transversâ nigricanti.

$\gamma$ antennis totis nigris; squamulis piceis; abdomine segmento secundo punctis tribus nigris intermedio subquadrato, tertio maculâ mediâ nigricanti. 
This insect appears to be the Andrena marginata of Fabricius; when first taken I have sometimes found the whole abdomen red, but this colour in the three last segments assumes a blackish hue. The abdomen of his specimens he describes as ferruginous, in ours the two intermediate segments are of a pale red, and the whole abdomen is covered with down, which, if it be viewed from behind, gives it a reddish hue; the yellow hairs with which the margins of the last segments are fringed, in insects long disclosed will turn paler. Panzer's figure represents our insect with tolerable accuracy, only the thorax is too intensely red. Variety $\gamma$, I suspect, may be the Nomada Hattorfiana of Fabricius. As Schrank was the first describer of the species in question, under the name of Apis Cetii $(q)$, I have named it after that ingenious entomologist.

affinis. 43. M. nigra, cinereo-subvillosa; thorace rufescenti; abdomine subtomentoso, segmentis posticis flavo-ciliatis.

MUS. Kirly.

Long. Corp. Lin. $4 \frac{1}{2}$.

$H a l$. Coddenhamix, prope Needham Market in Suffolciâ, bis capta.

DESCR. Acul.

CORPUS nigrum, cinereo-villosum.

(q) From mount Cetius, now called Kallenberg, or according to some Karemberg.

Caput, 
MELITTA. (**. c.)

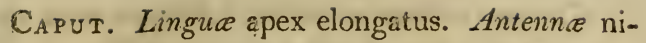
græ. Facies maculâ sericeo-pallidâ ponè antennas, ut in præcedente $(r)$.

Truncus. Thorax villis e flavo rufescentibus subpubescens. Squamulce piceæ. Alce subhyalinæ, apice nervisque nigricantibus. Pedes cinereo-hirti, tibiis posticis scopâ supra nigrâ, subtus pallidâ, certo situ versicolori. Scopulce fulvescunt.

Aв Domen ovale, nigrum, tomentoso-flavescens anum versus maximè. Segmentorum margines pilis pallidè flavis ciliati. Ani Fimbria flava. Venter convexus, nitidus, segmentis margine longiùs ciliatis.

This insect is distinguished from the preceding, which it greatly resembles if it be not a variety of it, by the colour of its abdomen, which is entirely black, without any red belt.

44. M. nigra, griseo-villosa; thorace pube rufâ; fulvago. abdomine punctulato, nitido; pedibus posticis, anoque, fulvis.

FIG. Apis fulvago. Christii Hymenopt. p. 189. tal.16. fig.7.

MWS. D. Marsham, Lathlury, Sowerby, Kirby.

Long. Corp. Lin. 4.

Hal. Barhamix, mense Junio anni 1799 locis graminosis in floribus frequens.

DESCR. Acul.

CORPUS nigrum, griseo-villosum.

(r) Tab, 4. **. c. fig. 16. a a.

Caput, 
Caput. Antenne nigræ. Linguce apex elon- gatus. Maxilla basi obtusangulæ.

Truncus. Thorax pube haud densâ, obscurè rufa. Squamula piceæ. Ale subhyalinæ, apice obscuriores; nervis, costali interiore nigro excepto, fuscis. Pedes nigri, rufescentehirti, posticis rufo-fulvis, femoribus nigris. Scope, item Scopulce, aureæ. Digiti antici, Tarsique intermedii, ferruginei. Flocculus pallidus.

Авдомen subovale, supra convexum, nitidum, punctulatum, subglabrum. Ani Fimbria, et segmenti penultimi cilia marginalis, fulvæ. $V$ enter rufescente-hirtus, anum versus præcipuè.

This insect appears to agree with the Apis fulvago of Christius. I have usually found it scarce, but in the year 1799 it was very plentiful.

alüicans. 45. M. nigra, albicante-subvillosa; thorace, anoque, ferrugineis; tibiis plantisque posticis fulvis.

Apis allicans hirsuta, nigra; thorace, abdomineque apice fulvescente.

Miill. Zool. Dan. n. 1930.

Apis sylvestris thorace et pedibus exteritus lanugine sordidè fulvâ vestitis, squamis imis ad margines pilis albentibus fimbriatis.

Rai. Hist. Ins. p. 242, n. 5.

FIG. Apis hosmorrhoidalis. Christii IIymenopt. p. 189, tab. 16. fig. 8. 
MUUS. D. Marsham, Latham, $M^{\circ}$ Leay, Haworth, Trimmer, Sowerly, Lathbury, Kirly.

Long. Corp. Lin. $4 \frac{\pi}{4}-5$.

Hab. Barhamiæ, mense Maio in floribus frequentissima, præsertim Taraxaci.

DESCR. Acul.

CORPUS nigrum, albido-villosum.

CAput. Antenne nigræ. Facies utrinque pone antennas maculâ sericeo-pallidâ, nisi certo situ et sub lente vix conspicuâ.

Truncus. Thorax pube densâ, brevi, ferrugineâ, tectus. Squamula rufæ. Alce hyalinæ, apice paulò obscuriores; nervis testaceis, costali interiore nigro. Pedes pallido-hirti, tibiis, tarsisque posticis, scopulisque, fulvis. Scope pallidè flavæ. Tarsi intermedii obscurè ferruginei.

Ав domen ovale, piceo-nigrum, supra convexum, glabrum, punctulatissimum, lateribus albido-villosulis; segmentis tribus intermediis lineâ transversâ, arcuatâ, elevatiusculâ. Ani Fimbria ferruginea. Venter segmentis margine albido-ciliatis; anum versus fulvescunt villi.

Maris Corpus griseo-villosum. Caput hirsutum. Antenne thoracis longitudine, articulis arcuatis. Thorax pilis subrufis longius villosus. Abdomen angustum, pilosulum.

M. albicans has usually been regarded in this country, as the Apis helvola of Linneus; unon this 
head I always entertained considerable doubts, and when I consulted the authentic specimen of that insect still preserved in the Linnean cabinet, I found that I was not mistaken, the true $A$. helvola being very distinct, as will appear hereafter. The definitions of the Zoologia Danica are so short, and unaccompanied by longer descriptions, that it is not always easy to say what insect is intended by them, but I think in my reference to that work upon this occasion I am not mistaken. Christius gives a figure of our insect as the Andrena hemorrhoidalis of Fabricius, which, however, is very different, it will be described in the course of this work. M. albicans is one of our most common Melitta.

pilipes, 46. M. aterrima, subvillosa; abdomine nitido; tibiis posticis scopâ albidâ.

Andrena pilipes glabra, atra; pedibus posticis albo ciliatis; alis fuscis.

Fal. Ent. Syst. Em. n. 21.

Andrena ciliatu. Fab. Spec. Ins. 1. p. 474, n. 12.

Lin. Syst. Nat. ed. Gmel. Apis, p. 2792. n. 190.

Ajis atra tota nigra, abdomine nitenti, alis fuscis.

Schrank. Enumt. Ins. Austr. n. $\$ 14$.

FIG. Reaum. Hist. Ins. tom. 6. Mem. 4. p. 95. tab. 9. f.g. 2 ?

Schaf: Icon. tab. 224. fig. 3, 4.

Andrcna aterrima atra, nitida; thorace posticè nigro, pubescenti; tibiis posticis extus a!bo-villosis; alis apice nigris.

Panx.er. Fn. Ins. Germ. Init. n. 64. tál. 19.

Apis aterrima. Christii Hymenopt. p. 130. tal. 16. fig.6?

carbonaria. Ibia. p. 201. tal. 17. fig. 13 ?

MUS. 


$$
\text { MELITTA. (**. c.) }
$$

MUS. D. Marsham, Smith, Latham, Trimmer, Haworth, Sowerly, Lathbury, Kirby.

Long. Corp. Lin. 5-7.

$\mathrm{Hab}$. Barhamiæ, cuniculos fodiens cylindricos in terræ sabulosæ sectionibus verticalibus, inibique nidificans. In floribus haud rara. Allium spirat recens insectum.

DESCR. Acul.

CORPUS aterrimum, nigro-subpubescens.

$\mathrm{C}_{\mathrm{APU}} \mathrm{T}$ villosum. Facies inter oculos lata. Antenne subtus nigro-piceæ.

Truncus. Squamulce atræ. Alce paululùm infuscatæ, apice nigræ; nervis, excepto costali interiore nigro, ferrugineis. Tilice posticæ scopâ albidâ. Femora postica albido barbata. Scopula fuscæ. Flocculus obsoletus.

Авдомen ellipticum, lucidum, supra glabriusculum, segmento primo villosulo. Ani Fimbria nigra.

Maris Antenne thorace breviores. Thorax pilis subnigris $\int$. fuscis villosus. Pedes postici hirsutie nigrâ.

This Melitta kas been described, under different names, by a variety of authors. It appears to be the Apis atra of Schrank, but not of Scopoli, the Andrena pilipes of Fabricius, the Andrena aterrima of Panzer, and the Apis aterrima and carbonaria of Christius, for I take both these latter insects to be varieties of $M$. pilipes, the one with clouded and the other with unclouded wings; he does not, however, give the white scopa, which makes these synonyms 
nonyms rather doubtful, they may be desigried, however, for male insects. The synonym of Reaumur is dubious, since he says of his insect " les aîles sont d'un violet foncé," which is not the case with ours. Fabricius suspects that this species may be the Apis retusa of Linneus, but upon the authority of the Linnean cabinet $I$ can venture to assert that it is very different from that insect. Indeed the principal character which this great naturalist selected to denote that species (aldominis lasi retusâ) is not to be found in this.

When this little insect has loaded the hair upon the sides of its metathorax, and its posterior legs with pollen, the contrast between the sable hue of the animal and the whiteness of the pollen is very striking.

cineraria.47. M. atra, albido-pubescens; thorace hirsuto fascià atrâ; abdomine atro-cærulescenti.

\section{ACUL.}

Apis cineraria nigra; thorace hirsuto albicante fascil nigrâ; abdomine cærulescente.

Lin. Syst. Nat. ed. 12. F Gmel. p. 2771. n. 5. Fn. Suec, n. 1698.

Fal. Ent. Syst. Em, n. 67.

Vill. Ent. Eur. 3. n. 5.

Apis atra nigerrima tota; fronte et thorace anticè ef posticè albo tomentosis; abdomine subrotundo; alis semifuscis.

Scop. Ent. Car. n. 797.

loss. Fn. Elrusc. n. 917. 
FIG. Schoeff. Ic. tal. 22.fig. 5, 6 .

Apis atra Christii Hymenopt. p. 174. tal. 14. fg. 1.

Panzer. Fn. Ins. Germ. Init. n. 56. tab. 14.

MAS.

Apis nigra, hirsutie cinereâ.

Geoffr. Hist. Ins. Par. 2. p. 412. n. 8 .

Apis cinerea. Fourcroy. Ent. Par. n. 8.

MUS. D. Smith Linnean. Marsham, Latham, Haworth, Trimmer, Kirby.

Long. Corp. Lin. 5-6.

Hab. Prope Londinum haud rara. Mas semel a $\mathbf{D}$.

Lathbury in Suffolciâ captus.

DESCR. Acul.

CORPUS atrum, hirsutie cinereo-albidâ.

Caput. Facies hirsuta, vertice calvo. Antenne capite longiores, nigræ.

TRUNCUS supra mollissimè hirsutus, fasciâ inter alas atrà. Squamulce atræ. Alce hyalinæ, apice nervisque nigricantibus. Pedes atri, hirti, femoribus anticis albido-lanatis. Tarsi fusci, plantis pilosissimis; anteriores pallidiores. Flocculus nigricans.

Ав DомеN subrotundum, glabrum, nitidum, atro-violascens. Ani Fimbria nigricans. Venter convexus, hirtus anum versus præcipuè.

Maris Antenne thoracis ferè longitudine. Tho$\operatorname{rax}$ fasciâ atrâ, obsoletâ. Alce apice obscuriores. Femora omnia barbâ albicanti. Abdomen lanceolatum, segmentis duobus anticis villoso-albicantibus. 
Scopoli has given this insect under the name of Apis atra, and Christius and Panzer have done the same. It is, however, the genuine Apis cineraria of Linneus, as appears from the authentic specimen of the Linnean cabinet. The Apis cineraria of Christius belongs to the species I am going next to describe.

pratensis.48. M. atra, villosa; trunco hirsuto-albicanti.

Apis pratensis pubescens, nigra; fronte pilis nigris, thorace albidis hirsuto.

Miill. Zool. Dan. n. 1912.

Andrena carbonaria atra, thorace cinereo-pubescente; pedibus lævibus; alis fuscis.

Fal. Ent. Syst. Em. n. 22.

FIG. Apis cineraria. Christii Hymenopt. p. 201. tab.17. fig. 14.

MUS. D. Marsham, Trimmer, Kirly.

$$
\text { Long. Corp. Lin. } 5 \frac{1}{2} \text {. }
$$

Hab. Barhamiæ, in floribus capta tempore vernali, sed rara admodum.

\section{DESCR. Mas.}

CORPUS atrum, pube nigricanti.

Caput. Facies atro-hirsuta. Verticis pili albido-cinerei. Antennce thorace vix breviores, piceo-nigræ, nitidæ, articulis subarcuatis.

TRU NCUs pilis albido-cinereis subhirsutus. Squamule piceæ. Alæ subhyalinæ, apice fuscæ; nervis testaceis, costali interiore nigro. Pedes atri, nigro-hirti. Scopula obscure ferrugineæ.

ABDOMEN lanceolato-ovatum, lucidum, pilis 
albido-cinereis parciùs villosum. Anus pilosonigricans.

Obs. In adultioribus thoracis pubes sordescit.

$M$. pratensis much resembles the male of $M$. cineraria, but the hirsuties of its head is black, its abdomen is of a different form, and has no tinge of violet, and its wings are black at their tips It has been long ago described in the Zoologia Danica. Fabricius gives it; if I am not mistaken in his insect, as the $A$. carbonaria, but that, as appears from the authentic specimen preserved in the Linnean cabinet, is very different, and indeed is no Apis, it seems to belong rather to the Fabrician genus Scolia.

49. M. atra, villosa; trunco supra hirsuto-rufo. thoracica. ACUL.

Apis thrracica, atra; thorace rufo; alis apice fuscis. Fab. Ent. Syst. Em. n. 63.

Lin. Syst. Nat. ed. Gmel. p. 2775. n.77.

Vill. Ent. Eur. 3. n. 75.

FIG. Schaef: Ic. tab. 254. fig. 6, 7 .

Harris, Exp. tab.40. fig. 19.

Andrena bicolor. Christii Hymenopt. p. 177. tab. 14. fig. 5 .

\section{MAS.}

Andrena licolor, thorace villoso-ferrugineo; abdomino atro immaculato.

Fal. Ent. Syst. Em. n. 12.

Lin. Syst. Nat. ed. Gmel. Apis, p. 2791. n.179.

Vill. Ent. Eur. 3. Apis, n.73.

Ross. Fn. Etrusc. n. 896. 
FIG. Schaff. Ic. tal. 32. fig. 2 .

Apis thoracica. Christii Hymenopt. p. 178. tab. 1' fig. 6.

Andrena licolor. Panzer. Fn. Ins. Germ. Init. n. 65. tal. 19.

MUS. D. Marsham, Latham, Trimmer, Sowerby, Lathbury, Kirly.

Long. Corp. Lin. 6-6 $\frac{3}{4}$.

Hal. Barhamix, $\beta$ in floribus tempore vernali frequen: satis, a semel capta a D. Marsham.

DESCR. Acul.

CORPUS atrum, pube nigricanti.

Caput hirsutum, vertice calvo. Antennee nigræ. Truxcus supra hirsutie densâ, ferrugineo-rufâ tectus. Squamula atræ. Alce infuscatæ, dimidio postico niģricanti maculâ mediâ albidâ ; nervis nigris. Pedes nigro-hirti, tarsis anticis, digitisque quatuor posticis, fuscis. Scopule fusco-nigræe.

Aв о $:$ en ellipticum, glabrum, luciàum. Ani Fimbria nigricans. Venter convexus, nigrovillosus, anum versus maximè.

I ar. ß corporis hirsutie atrâ, thoracis ferrugineâ ; alis subhyalinis, apice paulò obscurioribus; nervis, excepto costali interiore nigro, ferrugincis. An eadem?

Naris Antenna thorace breviores, nigro-picex, articulis subarcuatis. Alae immaculatæ, nervis ut in sexús aculcati varietate $\beta$. Ábdomen subovatum, pilosulum. 
I observed in the introductory part of the work $(s)$, that Fabricius had placed the two sexes of this insect in two different genera. He appears to have been led to do this by the difference of their form, the male being much more slende: than the other sex, without inspecting their instrumenta cibaria, which he would have found tom be exactly alike. Christius has given the male for A. thoracica, and the female for A. licolor. Fanzer's figure of the male is extremely accurate. Varicty $\beta$ of the aculeate sex is common enounh with us, but I never met with more than a single specimen of $\alpha$, which appears to be the genuine $A$. thoracica, and that was given me by Mr. Mar. sham. They may be distinct species, but they are too similar to be separated, without a more striking difference than merely the colour of their wings.

50. M. atra, subvillosa; thorace hirsuto-flaves-melanrc:centi; abdomine ovato, nigro.

MUS. Kirly.

\section{I ong. Corp. Lin. 6.}

Hab. In Angliâ, a D. Guodenuigh semel lecta.

DESCR. Mas.

CORPUS atrum, pube nigricanti.

CAput. Facies atra, hirsuta. Vertex calvus.

Occiput pilis flavescentibus. Antennce thorace breviores, nigræ, articulis subarcuatis.

Truncus supra hirsuto-flavescens. Squamulce

(s) Vid. vol, 1. Introductory Remarks, p. 67.

H 3

piceæ. 
piceæ. Ala subtestaceæ, nervis ferrugineis, costali interiore nigro. Pedes nigro-hirti. Scopulce fuscr. Digiti obscurè ferruginei.

AB DOMEN breve, ovatum, acutum, nigrum, pilosulum.

This insect much resembles the male of the preceding species, but it is larger, the down of the thorax is shorter, and rather yellow, and the abdomen is wider in proportion, and not so intensely black.

nitida. 51. M. nigra, pallido-subvillosa ; thorace hirsutofulvo; abdomine nitido; tibiis posticis scopâ versicolori.

Apis subhirsuta, fusca; abdomine nitido; pedibus villosis.

Geofr. Hist. Ins. Par:2.p. 407. n. 2.

Ajis nitida. Fourcroy. Ent. Par. n. 2.

Apis cunicularia. Miller. inter notcus M. S. Graianas supra citatas.

Apis sylvestris corpore productiore, vulgari mellificâ paulò minor; thorace fulvo, abdomine nigro.

Rai. Hist. Ins. p. 242. n. 4.

MUS. D. Marsham, Smith, Latham, Haworth, Trimmer, Lathbury, Sou'erly, Kirly.

Long. Corp. Lin. $4 \frac{1}{2}-6$.

Hal. Barhamix in floribus et locis apricis mensibus Aprile ct Maio frequens. Mas in Salicum amentis masculis:

DESCR. Acul.

CORPUS nigrum, hirsutic pallida f. albicanti.

CAPut. Facies fusco-villosa, anticè barbâ denså ạlbida ; 
albidâ ; vertice calvo. Oculorum intervallum latissimum. Antenne fusco-nigræ.

TRUNCus supra pube, densâ admodum, fulvâ mollis. Squamule nigræ. Ale subhyalinæ, apice nigricantes; nervis testaceis, costali interiore nigro. Pedes fusco-pilosi. Tilice posticæ scopâ supra nigrâ, subtus albidâ, certo situ, versicolori.

Авдомеn subovale, nitidum, fusco-nigrum, segmentis tribus anticis utrinque villoso-pallidis. Ani Fimbria nigricans. Venter convexus, segmentis margine ciliâ longâ, albicanti.

Var. $\beta$ thoracis hirsutie flavescenti; plantis pallido-pilosis.

$\gamma$ thoracis hirsutie cinerascenti.

Maris Facies barbâ longâ et densâ infra antennas tecta. Antennce thorace vix breviores. Abdomen lanceolatum, nitidissimum, albidopilosulum. Pedes pallido-hirti.

Var. $\beta$ dimidio minor, thoracis hirsutie albicanti.

This insect is often mistaken for the Apis cunicularia of Linneus. As such it is described by Miller in an interleaved copy of the Systema Naturæ, which belonged to the late Mr. Gray (so justly celebrated as the Pindar of our age) and contains several valuable descriptions and observations of that great genius, who was an excellent naturalist as well as poet. The following are Miller's words. "Apis cunicularia. Mense Aprili 
frequens in fossis sabulosis collium Hogmagog prope Cantabrigiam. Tota fusco-nigra, abdomine supra glabriusculo, nitente; thorace villoso fulvoferrugineo; maculâ alæ marginali subfuscâ. Simillima A. mellifice." All the species of this fanily, at least so far as I am acquainted with them, excavate cuniculi for their little nests; and many of them, and among the rest $M$. nitida, have at tirst sight a considerable resemblance to the common hive bee; these circumstances occasion many different insects to be mistaken for $A$. cunicularia. Linneus has given no longer description of that insect, and his definition of it will agree with so many distinct species, that it is not to be wondered at, if this has generated errors. To prevent all future mistakes and confusion with respect to this insect, I shall give below a full description of it drawn from the authentic specimens preserved in the Linnean cabinet $(t)$.

52. M.

( $t$ ) cuni- M. atra, grisescente-pubescens; thorace ferrugineo ; tibiis poscularia. ticis undique villosis; abdomine hirsutulo, subovato, acuto.

Apis cunicularia pubescens; thorace ferrugineo, abdo: mine fusco, pedibus undique viliosis.

Lin. Syst. Nat. ed. 12. n.23. Fn. Suec. 169 s.

MUS. D. Smith Linnean.

Long. Corp. Lin. 6 $\frac{\mathrm{r}}{2}$.

Hal. in Europæ terrâ sabulosâ sicciore, quam foraminibus plurimis parum remotis penetrat, et distinctæ inxdificant plures. Simillima A. mellifica. Lin. Obs. A. mellifice frima facie simillima, revera tamen plurimùm differt, et hujus generis est. $\mathrm{K}$.

DESCR. 
52.M. nigra, albido-pubescens; thorace rufescenti; tilialis. tibiis posticis fulvis, scopâ fulvo-aureâ.

MUS. D. Marsham, Sowerby, Kirly.

$$
\text { Long. Corp. Lin. } 7 \frac{\pi}{4} \text {. }
$$

$H a b$. Barhamiæ, in floribus Taraxaci tempore vernali obvia, sed rariùs.

DESCR. Acul.

CORPUS nigrum, albido-pubescens.

CAPU t villosum, vertice calvo. Occipitis villi flavescunt. Antennce nigræ. Oculorum intervallum latissimum.

DESCR. Acul.

CORPUS nigrum, pube grisescenti.

CAPUt undique hirsutum. Oculorum intervallum latissimum. Antenina nigre.

TrUncus undique hirsutie densâ mollis, subtus griseâ, supra ferrugineâ. Squamulce nigræ. Alı subtestaceæ nervis nigricantibus. Pedes griseo-hirti, tibiis posticis undique villosis. Femora postica barbâ longâ et densâ pallidâ.

AвDоMEN ex ovato subconicum, nigrum; tergo grisescentehirsutulo. Anus vix fimbriatus, acutus.

$\operatorname{Var} . \beta$ trunco supra hirsutie cinerascenti.

Obs. Aldomen ex hirsutie fuscum esse, seu potiùs fuscocinereum videtur, ast revera nigrum est.

Since the Linnean definition of this insect was intended principally to distinguish it from $A$. mellifica, which at first sight it much resembles, although when closely examined it will be found widely different; I have taken the liberty of altering it, so as to distinguish it from such of its congeners as will answer to that definition, and with which it is liable to be confounded. I have excluded all the synonyms usually referred to for it, as they may very probably belong to other insects. That of Christius evidently does. (p. 164. tab. 13. fig. 4.) I cannot find that this Melitta has ever been taken in England. 
TRExCEs supra pube rufescenti tectus. Squa. mule picex. Alis subtestacex, apice nigticantes; nervis, costali interiore nigro escepto, testaceis. Pedes rufescente-pilcsi, femoribus albido-lanatis, posticis subtus apice rufis. Tícia posticæ fulvæ. scopâ fulro-aureá undique restitæ. Tarsi posteriores, item Digiti primi et secundi paris, Scopulaque, ferruginei. ABDOMEx suboratum, nitidum, tergo converiusculo, albido-hirsutulo, segmentis margine depressiusculis. Ani Fimbria nigricans. Venter conrexus, segmentis margine albido-ciliatis, anum versus densiùs et longiùs.

Var. 3 trunco subtus pube grisescenti; tarsis intermediis totis ferrugineis; femoribus posticis apice immaculatis.

Loufet- 53. M. nigra, pallido-pubescens; abdomine piloso eila. nigro-æneo; thorace, digitis, tibiisque posticis, rufis. .

MUS. Kirly.

$$
\text { Long. Corp. Lin. } 6 .
$$

Hot. Barbamix in fioribus Torexci serel lecta.

DESCR. Acul.

CORPUS nizrum, pallido-pubescens.

CAPUT. Facies infra antennas hirsutie, pro situ nunc nigricanti nunc cinerascenti, tecta. Fertex calvus. Occipitis pili nigri. Genarum barba albida. Oculorum intervallum latissimum.

Truxces supra hirsutie, haud densá, rufescenti obsitus. Squamule nigra. Ale hyalinæ, apice 
apice obscuriores, nervis flavis, costale interiori nigro. Pedes rufescente-pilosi. Feniorum barba albida. Tilice posticæ rufæ, scopa fulro-aurea. Tarsi quatuor posteriores, atque Digiti antici, ferrugineo-rufi. Palma ex pilis fusco-cinereæ. Scopula fulræ.

ABDOMEY subovatum, nigro-æneum, converiusculum, rufescente-hirsutulum, segmentis margine albidioribus. Ani Fimbria fusca. Venter pallido-hirtus.

Maris Corpus rufescente-rillosum. Antennce thoracis longitudine, articulis arcuatis. Titice posticæ obscurè ferrugineæ, liturâ fuscâ. Aldomen densitus pilosum.

This species connects $M$. titialis with that which I am next to describe; from the former it borrows the colour of its posterior tibia; from the latter the nigro-æneous tinge of its abdomen.

54. M. nigra, fulro-pubescens; capite anoque nigroatris; abdomine subhirsuto, nigro-æneo.

MUS. D. Marshar, Smilh, Drary Apis, =. 43. Heworth, Trimmer, Sourerly, Lashtwry, Kirly.

Long. Corg. Lin. 6-7.

Hel. Ea-hamix, texpore verzali freçueds satis. Miss in Selierm aneatis.

DESCR. Acul.

CORPU'S niz̧rum, pube densâ fulvă.

CAptr. Facies atro-hirsuta, Genarm barba fulrescit. Tertex calrus. Spatium inter Oculos interjectum latum.

Tresers. 
Truncus. Thoracis pubes rufa. Squamule. piceæ. Ala subhyalinæ, nervis testaceis, costali interiore nigro. Anastomosis ferruginea. Pedes nigri, supra ex pilis fucci, subtus tamen pili fulvescunt. Femorum lana pallida. Tilice poticæ scopâ densâ fulvâ undique obsitæ. Scopulce ferrugineæ.

Авдомеn ovale, supra nigro-æneum, fulvescente-subhirsutum, ano atro. Venter convexus, per fascias hirtus.

Var. B. minor, facie, circa basin antennarum, hirsutic sordidè fulvâ.

Maris Facies ut in varietate $\beta$. Antennce thoracis longitudine. Maxilla basi obtusangulæ, Pedes fulvo-hirti. Aldomen ovatum.

$V a r$. faciei hirsutie rufescenti.

Obs. Aldominis color nigro-ceneus, tum hujus tum pracedentis speciei, ex pilis, qui tamen scorsim fulvescunt, exoritur; pilis enim abrasis, aldomen fit nigrum.

This insect approaches nearer to the Apis cunicularia of Linneus, than any other English species with which I am acquainted: but it is sufficiently distinguished from it, by its black head and anus, and the form and colour of its abdomen. It is rèmarkable that the black abdomen should receive, from the tawney hairs which cover it, a nigro-æneous tinge.

Upon this insect I discovered, last spring, a very singular animal, which seems appropriated to the present 


$$
\text { MELITTA. (**。c) }
$$

present genus. I had previously more than onee observed upon other species something that I took to be a kind of Acarus, which appeared to be immoveably fixed just at the inosculations of the dorsal segments of the abdomen: at length, finding three or four upon a specimen of $M$. nigro-cenea, I determined not to lose that opportunity of taking one off to examine and describe; but what was my astonishment when upon my attempting to disengage it with a pin, I drew forth from the body of the Melitta a white, fleshy larva, a quarter of an inch in length; the head of which I had mistaken for an Acarus $(u)$. How this animal receives its nourishment seems a mystery. Upon examining the head under a strong magnifier I could not discover any mouth or proboscis with which it might perforate the corneous covering of the abdomen, and so support itself by suction $(x)$, on the under side of the head at its junction with the body there was a concavity $(y)$; but I could observe nothing in this but a uniform, unbroken surface. As the body of the animal is inserted in the body of the Melitta, does that part receive its nutriment from it by absorption? My memory does not furnish me with any instance of this kind: but lave the vermes intesitinales any mouth?

After I had examined one specimen I attempted to extract a second, and the reader may imagine how greatly my astouishment was increased, when
(u) Tab. 14. n. 11. fig. 7. and fig: 9. $a$.
(y) Ibid. fig. $7 \cdot b$.
(x) Ibid fig. 8:
after 
after I had drawn it out but a little way, I saw its skin burst, and a head as black as ink, with large staring eyes and antennæ consisting of two branches, break forth, and move itself briskly from side to side. It looked like a little imp of darkness just emerging from the infernal regions. My eagerness to set free from its confinement this extraordinary animal may be easily conjectured. Indeed I was impatient to become better acquainted with so singular a creature. When it was completely disengaged, and I had secured it from making. its escape, I set myself to examine it as accurately as possible; and I found, after a careful inquiry, that I had not only got a non-descript, but also an insect of a new genus, whose very class seemed dubious. From its mode of life it ought to belong to the Linnean genus Ichneumon in the Hymenoptera; but it has neither stemmata, nor four wings, and its palpi are not at all similar to those of the insects of that class $(z)$. From its elytra, (which, however, are placed in a very extraordinary situation, being fixed to the sides of the thorax) it ought to be a Coleopterous insect, but it seems to possess but little of the general habit and character of that class: perhaps it had better be considered as Hemipterous, but till an opportunity occurs of examining more specimens it would be rash to speak too positively upon this head.

After I had sufficiently examined my animal, I made a rude sketch of it, its antennæ, \&c. $(a)$ : and

(i) Tab. 14. n.11. fig.2 , $a, b$, and fig. 5. (a) Ibid, fig.1-9. 
it was well that I did, for upon leaving home for some weeks, when I returned, it was so miserably mauled by the great enemy of the entomologist, the Acarus destructor (b), that I should have been unable to give a tolerable idea of it, since both elytra and antennæ were gone: enough of it, however, still remains to shew what it was. I have not as yet met with another.

I shall attempt a description of it below (c)

55. $\mathrm{M}_{\text {。 }}$

(b) Schrank. Enum. Ins. Austr. n. 1057. tab. 2. fig. H.

(c) STYLOPS $(a)$. Character Essentialis.

Antenne bipartitæ. Oculi pedunculati.

Character Artificialis.

Antennce bipartitæ $(b)$.

Oculi pedunculati $(c)$.

Elytra lateribus thoracis affixa $(d)$.

Scutellum porrectum, abdomen obtegens $(e)$,

1. St. aterrima; alis corpore majoribus; pedibus fuscis.

Melitic.

MUS. Kirb̈y.

Long. Corp. Lin. $1 \frac{1}{2}$.

Hab. Barhamiæ, larva in Melittarum abdomine para. sitica.

DESCR. CORPUS aterrimum, obscurum.

$\mathrm{C}_{\mathrm{APUT}}$ anticè obsoletè trilobum $(f)$. Palpi quatuor, exteriores biarticulati, articulo primo subclavato, secundo lanceolato, acuto $(g)$; interiores breviores, exarticulati, tenues, apicem versus paulò crassiores $(h)$. Antennee capite lon-

(a) Them. sulos, columna; and $\omega \psi$, oculus.

(b) Tab. 14. n. 11. fig. 2. d, c. and 3,4 .

(c) lbid. fig. I. $f, f$.

(d) Ibid. $g \mathrm{~g} \cdot$

(e) lbid. $b$. and fig, 6, $b$.

(g) Ibid. fig. 2. 5. $a$. (b) Ibid, $b b_{0}$

giores, 
atriceps. 55. M. nigra, rufescente-villosa; capite atro; tars sis rufis.

MUS, D. Marsham, Trimmer, Kïly.

\section{Long. Corp. Lin. $5 \frac{1}{2}-6 \frac{x}{4}$.}

Hab. Barhamix, in Salicum amentis tempore vernalí satis frequens.

\section{DESCR. Mas.}

CORPUS nigrum, pube densâ rufescenti.

CAput. Facies atro-hirsuta. Occipitis villi sordescunt. Antenna thoracis férè longitudine, nigræ, articulis subarcuatis.

giores, articulö primo magno, brevi (i), ramos duos emittente; intériori breviori, latiori, exarticulato $(k)$; exteriori longiori, tenuiori, triarticulato $(l)$. Oculi magni, prominuli, conspicuè reticulati, pedunculo brevi, crasso insidentes $(m)$. Vertex planiusculus.

Truncus. Elytra parva, sublinearia, thoracis lateribus affixa $(n)$. Ala magnæ, corpore longiores, plicatæ, lacteæ, costâ, lineolâque submarginali, nigricantibus (o) Scutellum porrectum, elongatum, calceiforme, abdomen obtegens $(p)$; processu corneo utrinque munitum $(q)$. Pedes compresi, picei.

AвDом EN sub scutelli tegmine delitescens $(r)$, carnosum, ano truncato, subemarginato $(s)$.

Obs. Larvœ corpus sulcylindricum, molle, allidum; in aldomine Melitta insertum; capite cxerto, corneo, cordato, planiusculo, subrufo, posticè nigro, subtus posticè concavo $(t)$.

(i) Tab. 14. n. 11. fig. 1, b. fig. 3, 4.a. (k) Ibid fig. 2.4.b. fig.4.b.

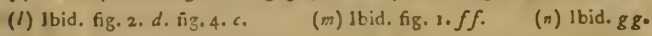
(o) 1 bid. $1 \%$
$(f)$ Ihid. $b$. and fig. 6. $b$.
(q) Ibid. fig. 1 ig .

and fig. 6. d. (r) lbid. fig. 1. k. ( $\quad$ ( ) lbid. fig.6.c. $\quad(t)$ lbic. fig. $7,8,9.9$

TRUNCUS 
Truncus supra rufo-pubescens. Squamulce piceæ. Alce subhyalinæ, apice obscuriores; nervis, costali interiore nigro excepto, testaceis. Pedes rufescente-hirti, tarsis omnibus, tibiisque posticis, rufis.

A.в Dомеn ovato-lanceolatum, hirtum.

Var. s major, maxillis basi dente obsoleto; thoracis hirsutie fulvâ; plantis quatuor anterioribus nigris ; tibiis posticis apice tantùm rufis.

This species resembles the male of the two preceding ones; from M. Mouffetella, however, it seems sufficiently distinguished by its black head; and from $M$. nigro-anea by the colour of its tarsi, and the want of the black anus. I am not certain that variety $\beta$ is not a distinct species, although of the same sex, it is much larger than $\alpha$, and only the digiti of the four anterior legs are red. The posterior tibiæ also are red only at their tips.

56. M. nigra, rufescente-villosa; capite atro; ven-bimaculitre basi utrinque maculâ rufâ.

MUS. Kirly.

$$
\text { Long. Corp. Lin. } 5 \frac{1}{2} \text {. }
$$

Hal. Barhamiæ bis capta.

DESCR. Mas.

CORPUS nigrum, pube pallidè rufescenti.

CAPUT atrum, hirsutum. Maxillarum barba tamen, et Occipitis pili sordescunt. Antenne nigræ, thoracis vix longitudine, articulis arcuatis.

VOL. II.

I

Trunces 
MELITTA. (**. c.)

Truxcus pube sordidè rufescenti, $\int$. subgriseá, translucente nigredine corporis, supra obsitus. Squa mula nigræ. Ala subhyalinæ, apice obscuriores; nervis flavis, costali interiore nigro. Pedes hirti. Scopula fulvæ.

Ав оомеN ovato-lanceolatum, hirtum. Venter basi utrinque maculâ magnâ, rufâ.

The red spot on each side of the base of the underside of the abdomen, and the black tarsi, are the principal characters which separate this species from $M$. atriceps, which, in other respects, it a good deal resembles. Indeed, the males of the different species in this genus are often so similar, that, where we are unacquainted with the other sex, it is not always easy to say which is a species and which a varicty.

Trimmer-57. M. nigra, grisescente-pubescens; abdomine ana.

hirsutulo; tibiis posticis scopâ versicolori.

MUS. D. Marsham, Trimmer, Kirly.

Long. Corp. Lin. 7.

Hal. Barhamix in foribus $\Lambda$ ugusto medio 1799 semel lecta, $\beta$ bis in floribus horti mense Maio. Capta etiam a D. Jacobo Trimmer (entomologo cordato, et horum insectorum historix et oeconomix acerrimo indagatore) prope Hanwell Middlesexiæ.

DESCR. Acul.

CORPUS nigrum, grisescente-pubescens.

Ca Pu T. Facies posticè pilis nigricantibus. Vertex calvus. Maxillce basi obsoletè bidentatx. Antennce capite longiores, nigræ. 
Truncus supra pube rufescenti haud densâ tectus. Squamule piceæ. Alce hyalinæ, apice obscuriores; nervis testaceis, costali interiore nigro. Pedes fusco-pilosi, tibiis posticis scopâ supra nigrâ, subtus albidâ, certo situ versicolori. Digiti ferruginei.

AвDomen ovatum, grisescente-hirtum. Ani Fimbria atra. Venter segmentis basi pilis brevibus, nigricantibus obsitis; apice longioribus, pallidis ciliatis.

$V$ ar. $\beta$ adultior alis testaceis; abdominis hirsutie cinerascenti.

Obs. Primâ facie Api mellifica simillima est hac species.

$M$. Trimmerana strongly resembles $M$. cunicularia; but it is smaller, the form of its abdomen is very different, its anal fringe is black, and its scopæ are black above and white below. The antennæ of the aculeates of this species are much longer than is usual in that sex.

58. M. atra; thorace, abdominisque basi, hirsuto-varians. fulvis; tibiis posticis scopâ versicolori.

Apis varians nigra; thorace, abdominisque basi supernè, hirsuto-fulvis.

Ross. Fn. Etrusc. Mantiss. n. 317.

FIG. Panzer. Fn. Ins. Germ. Init. n. 56. tal. 12.

MUS. D. Marsham, Donovan, Kirly.

Long. Corp. Lin. 5-6.

Hab. In Angliâ, capta semel in floribus $P$. Mali in horto quodam Gippovicensi.

DESCR. 
DESCR. Acul.

CORPUS atrum, pubescens.

Caput pube nigricanti. Antenne nigræ, capite longiores.

Truncus supra hirsuto-fulvus, subtus pube rariore palliclà. Squamule ferrugineæ. Alce subhyalinæ, apice obscuriores; nervis, excepto costali interiore nigro, testaceis. Pedes nigri, fusco-pilosi, femorum barbâ pallidà. Tibiae posticæ scopà supra fusco-nigrâ, subtus argenteo-albidâ, certo situ versicolori. Tarsi obscurè ferruginci. Flocculus albidus.

A B DOMEN subcllipticum, anticè hirsuto-fulvum, posticè nigro-lirtum. Venter pilis sordidè nigricantibus hirtus.

Maris Corpus cinereo-villosum. Capitis hirsuties item cinerea. Maxilla forcipatæ, basi obtusangulæ. Antennce vix thorace breviores articulis arcuatis. Thoracis hirsuties rufescentepallicla. Pecies cinereo-hirti, digitis rufis. Scopula fulvæ. Aldomen lanceolatum, basi hirsuto-cinerascens.

This is given by Rossi and Panzer as the Aleille magonne a poils roux of Geoffroy $(d)$; but that is a genuine Apis, and belongs to one of the branches of that family, the individuals of which are distinguished by an inflected lip. Panzer's figure very accurately represents our insect, but he is quite mistaken in asserting that it is a male.

(d) Hist. Ins. Par. 2. p.409. n. 4. 
59. M. nigra, albido-villosa; thorace abdominis-helvola. que basi, hirsuto-ferrugineis; tibiis posticis scopâ flavescenti.

Apis helvola rufa, villosa, oblonga, subtus albida.

Lin. Syst. Nat. ed. 12. \& Gmel. p. 2791. n.16. Fn. Sulec. 1693.

Vill. Ent. Eur. 3. n. 13.

Fn. Frid. n. 645.

Forst. Cat. Brit. Ins. 712. Apis, n.6.

Andrena helvola thorace ferrugineo; abdomine cineascente.

Fab. Ent. Syst. Em. n. 11.

FIG. Tal. 15. fig. 9 .

MUS. D. Smiti Linnean. Marsham, Latham, Sowerly Ma:. Lathbury Mas. Kirby.

Long. Corp. Lin. 5.

Hal. Barhamiæ, flores Rilis nigri frequentans, sed rarior.

DESCR. Acul.

CORPUS nigrum, pube albidâ incanum.

Caput. Maxille forcipatæ. Occiput pilis flavescentibus. Vertex calvus. Antenne nigræ, capite longiores. Oculorum intervallum latissimum.

Truncus. Thorax pube ferrugineâ tectus. $M e$ tathorax villoso-flavescens. Squamulce ferrugineæ. Alce hyalinæ, apice obscuriores; nervis, costali interiore nigro excepto, testaccis. Pedes nigri, rufescente-pilosi, femorum barbà, flocculoque, albidis. Tilice posticæ scopâ flavescenti. 'Tarsi quatuor posteriores, Digitique antici, ferruginei. Scopulce fulvo-aurex. 
Aв Dorres suboratum, piloso-incanum, basi hirsuto-fulvum. Venter albido-hirtus, ano flavescenti.

Var. $\beta$ corporis hirsutie subflavâ; plantis nigris. Maris Corpus cinereo-villosum Caput thorace majus. Maxilla basi obtusangulæ. Antenna thorace breviores, articulis subarcuatis. Squamula piceæ. Digiti ferruginei. Aldomen ovato-lanceolatum, basi hirsuto-cinerascens, segmentis margine obscurè rufis.

This is the labelled Apis helvola of the Linnean cabinet; there are sereral specimens of the insect which I shall next describe placed by its side, which probably Linneus considered as nothing more than varieties of it. The description in the Fauna Suecica seems to have been taken from one of these; for the terms "Aldomen nigricans minus villosum. Tibice postice lana ferrugine $\hat{\text {, }}$, will not agree with the genuine $A$. helvola, and vice versâ, the last term of the nomen specificum in the Systema $\mathrm{Na}$ turæ, "sultus albida," does not coincide with this supposed variety, which underneath is of a deep black. At first sight, the abdomen of this insect looks as if half the tawny hairs had been rubbed off, and only a patch of them left at its base; but this circumstance constantly attends the most recent individuals.

Guynana60. M. atra, villosa; thorace, abdomine anticè, tibiisque posticis scopâ, ferrugineis. 


$$
\text { MELITTA. (**. c.) }
$$

Apis helvola. Ross. Fn. Etrusc. n. 895.

MUS. D. Smith Linnean. Marsham, Latham, $M c$ Leaz; Haworth, Sowerby, Lathbury, Trimmer, Kirby.

Long. Corp. Lin. 5.

Hal. Barhamiæ in floribus a primo vere ad serum autumnum frequentissima allium spirans. Mas circa terras apricas arenosas tempore yennali yolitat.

DESCR. Acul.

CORPUS aterrimum, pubescens.

CAPU trunco angustius, hirsutum. Antenna nigræ, capite longiores.

Truncus supra ferrugineo-hirsutus. Squamulce piceæ. Ala subhyalinæ, apice obscuriores; nervis ferrugineis, costali interiore nigro. $\mathrm{Pe}$ des atri, pilosi. Tivice posticæ extra scopâ ferrugineâ. Flocculus rufescens.

Ав оомеN subovatum, atrum, segmentis tribus anticis ferrugineo-subhirsutis.

Maris Corpus lineare. Antenne thorace breviores, articulis subarcuatis. Pedes rufescentehirti, posteriores maximè. Aldomen rufescente-hirsutulum.

Nemoria botanici periti, tum et nature scrutatoris indefessi, mihi et omnibus Historice $\mathrm{Na}$ turalis cultoritus semper amicissimum se prebentis, Nicolai Gwyn, M.D. Gippovicensis, hoc insectum dicatum volo.

This insect is extremely different from $M$. helvola, although confounded with it by Rossi, and, as observed above, by Linneus himself. I wenI 4 tirely 
tirely black, excepting only the thorax, the three first dorsal segments of the abdomen, and the scopæ, the hirsuties of which is ferruginous.

angustior.61. M. nigra; rufo-subvillosa; thorace pubescenti; femoribus, pedibusque quatuor anticis, piceis; postıcis ferrugineis.

MUS. D. Banks Acul. Kïly Mas.

Long. Corp. Lin. $4-4 \frac{\mathrm{r}}{2}$.

\Ia?. In Angliâ. Mas Barhamiæ lectus.

DESCR. Acul.

CORPUS nigrum pube rufâ.

Caput hirsutic fuscescenti. Antenna picex.

Truncus supra pube fulvescenti obsitus. Squamulce piceæ. Alce subhyalinæ, apice obscuriores; nervis ferrugineis, costali interiore nigro. Pecles picei, rufescente-pilosi. Tilice tamen et Tarsi postici ferruginei. Scopa rufa.

Ав DомЕN angustum, sublanceolatum, segmentis margine pilis rufescentibus ciliatis. Fenter fusco-hirtus.

Maris Corpus lineare, cincreo-villosulum. Caput trunco majus. Fucies infra antennas atrohirsuta. Antennae vix thorace breviores. Pedes postici rufo-picei. Aldomen cinerascente-pilosum.

$I$ have had no opportunity of comparing what I take to be the male of this Melitta with the other sex which is in Sir Joseph Banks's cabinet; but the colour of the legs, in which they appear to agree very nearly, has induced me to consider it as such.

62. $\mathrm{M}$ ? 
62. M. nigra, grisescente-subvillosa; capite atro ; picicornis. antennis piceis; abdomine fusco.

MUS. Kirb̄y.

$$
\text { Long. Corp. Lin. } 4 \frac{1}{2} \text {. }
$$

Hab. Barhamiæ, rarissima, semel tantùm lecta.

DESCR. Acul.

CORPUS nigrum, grisescente-subvillosum.

CAPUT atrum pube brevi, et haud densâ, nigra obsitum. Maxillce forcipatæ. Antennce capite longiores, rufo-piceæ, scapo nigro.

Truncus. Thorax pube, rarâ admodum, flavescenti. Squamula piceæ. Alce subtestaceæ, apice obscuriores, nervo costali interiore piceo. Tilice posticæ scopâ parvâ flavescenti. Flocculus obsoletus.

Ав DомеN ovatum, fuscum, grisescente-pilosum. Venter convexus.

63. M. nigra, hirsuto-cinerascens ; maxillis longi-spinigera. tudine capitis atri, basi spinâ filiformi armatiș.

FIG. Tab. 15. fig. 10.

MUS. D. Banks Apis helvola, Marsham, Kirly.

Long. Corp. Lin. 4-5.

Hal. Barhamiæ in Salicum amentis rarissima.

DESCR. Acul.

CORPUS nigrum, cinereo-hirsutum.

CAPUT magnum, trunco latius, aterrimum, hirsutum. Maxillce minaces, capite vix breviores, forcipatæ, subflexuosæ, sulco longitudinali supernè exaratæ, acutissimæ, apice edentulæ, 
MELITTA. (**, c.)

basi spinâ filiformi deorsum spectante armatx $(e)$. Gence posticè rectangulæ. Antenna nigræ, thoracis ferè longitudine, articulis arcuatis.

Truncus. Squamulce piceæ. Ala hyalinæ, iricolores, apice obscuriores; nervis, excepto costali interiore fusco, testaceis. Pedes grisescente-hirti, digitis ferrugineis. Scopula flavescunt.

Ав DомеN lanceolatum, nitidum, pilosum; segmentis tribus anticis margine rufo-membranaceis.

$V$ Var. $\beta$ minor, capite, respectu thoracis, minori ; maxillis brevioribus; thoracis hirsutie sordidè griseâ.

This is one of the most singular insects of this genus that I have ever seen. Its long, forcipate maxillæ, and large black head, give it a very ferocious aspect. The spine which arms the base of the maxillæ is, probably, only a sexual distinction. I do not find it described by any author; or if it be, the spines, its most striking characteristic, are overlooked. In Sir Joseph Banks's cabinet it stands as Apis helvola, it is the right-hand specimen.

armata. 64. M. nigra, cinerascente-villosa; maxillis longitudine capitis, basi dente armatis.

Apis armata fusca; capite, thoraceque griseis; maxilla basi dente armata; plantis luteis.

Mus. Lesk. p. 80. n. 514.

Lin. Syst. Nat. ed. Gmcl. p. 2790. n. 167.

(e) Tab, 4,**. c, fig. 8, a.

MUS. 
MUS. D. Marsham, Latham, Trimmer, Lathbury, Kirby.

Long. Corp. Lin. 4.

Hal. Barhamiæ in Salicum amentis, præcedenti frequentior. In Dauci Carotae umbellâ involutâ insomniantem semel prehendi.

DESCR. Mas.

CORPUS nigrum, cinereo-villosum.

CAPUT atrum, trunco majus, anticè pilis albidis, posticè nigris, longiùs barbatum. Maxille minaces, capitis ferè longitudine, forcipatæ, subflexuosæ, sulco longitudinali exaratæ, apice bidentatæ dente exteriori longiore, basi dente valido, subarcuato, deorsum spectante, armatæ $(f)$. Gence posticè rectangulæ. Antenne nigræ, thoracis vix longitudine.

Truncus hirsutus, supra hirsutie grisescenti. Squamule piceæ. Alce hyalinæ, apice obscuriores, splendidè iricolores; nervis testaceis, costali interiore nigro. Pedes grisescente-hirti, scopulis flavescentibus.

АвдомеN ovatum, fusco-nigrum, pilosulum, basi grisescente-hirsutum. Venter cinereohirtus, segmentis apice albido-ciliatis.

This Melitta, which appears to be the Apis armata of the Museum Leskeanum, somewhat resembles the preceding species; but, instead of a spine, the maxillæ are armed only with a tooth at their base, and their apex is bidentate ; the head also is of a different colour, and the abdomen of a different form.

$$
\text { (f) Tab. 4,**, c, fig. 7, a. }
$$


suldcn- 65. M. nigra, cinerascente-villosa; facie anticè tata. barbâ albâ; maxillis longitudine capitis, basi obtusangulis.

MUS. D. Sou'erly, Kirly.

Long. Corp. Lin. 4.

HIab. Barhamise rarissima.

DESCR. Mas.

CORPUS nigrum, cinereo-villosum.

CAPU trunco majus. Facies anticè barbâ longa et densâ argenteâ ornata. Maxillıe minaces, capite vix breviores, forcipatæ, subflexuosæ, apice bidentatæ dente exteriori longiore, sulco longitudinali exaratæ, basi dente obsoleto armatæ. Gence posticè rectangulæ. Antenne thoracis ferè longitudine.

TRUNCUs supra rufescente-villosus. Squamulce piceæ. Ala hyalinæ, apice obscuriores, splendidè iricolores; nervis, costali interiore fusco excepto, testaceis. Pedes grisescente-hirti, scopulis flavescentibus.

Ав donen lanceolatum, pilosulum, basi cinereovillosum, ano rufescente. Venter albido-hirtus. Var. \& maxillis basi absque dente obsoleto; thorace, abdominisque basi, hirsuto-ferrugineis.

$M$. sublentata is so similar to the preceding species, that it is not without some hesitation that I venture to separate them: but since they are both of the same sex, the absence of the strong tooth at the base of the maxillx, and the long silver beard which 
which covers the anterior part of the face seem to indicate that they belong to different females. Variety $\beta$ differs considerably from $\alpha$, but I think not sufficiently to make another species of it.

66. M. nigra, pallido-villosa; thorace fulvescenti ; picipes. abdomine fusco; pedibus rufo-piceis.

MUS. D. Drury Apis, n. 65.

\section{Long. Corp. Lin. 4.}

$H a b$. in Angliâ. Hanc unicam tantùm vidi.

DESCR. Mas.

CORPUS nigrum, pallido-pubescens.

$\mathrm{C}_{\mathrm{AP}} \mathrm{T}_{\mathrm{T}}$ thorace majus, hirsuto-grisescens. $F a-$ cies villoso-incana. Maxillae capite breviores, forcipatæ. Antennce nigræ.

Truncus supra fulvescenti-villosus. Alce hyalinæ, nervis testaceis. Pedes rufo-picei, pallido-hirti

Авдомел fuscum, nitidum, pilosulum. Venter segmentis margine pallido-ciliatis.

67. M. nigra, pallido-villosa; thorace hirsuto-fer-angulosa. rugineo; capite posțicè utrinque rectangulo.

MUS. Kirly.

$$
\text { Long. Corp. Lin. } 4 \frac{\mathrm{I}}{4} \text {. }
$$

Hal. in Angliâ, a D. Trimmer prope Londinum semel lecta.

DESCR. Mas.

CORPUS nigrum, pallido-villosum.

CaPU trunco latius. Maxille forcipatæ, capitc breviores, basi obtusangulæ $(h)$. Gence posticè

(h) Tab. 4,**. c. fig. 6 .

rectangula. 
rectangulæ. Antennæe nigræ, thorace vix breviores.

Truncus supra hirsutie, haud densâ, ferrugineâ obsitus. Squamula nigræ. Ala hyalinæ, apice obscuriores, splendidè iricolores; nervis ferrugineis, costali interiore nigro. Pedes pallidohirti.

Ав домеN lanceolatum, pilosum, basi fulvo-villosulum. Venter segmentis margine fimbriấ densissimâ, niveâ nitidè ciliatis.

This, as well as several of the preceding species, is distinguished from the other males of this genus by the right angle in which the head terminates on its lower side behind(i). It very nearly resembles the male of $M$. varians, but that insect is without the thick white fringe, by which the margin of the ventral segments of the abdomen of $M$. angulosa is terminated.

fulva. 68. M. atra; thorace, abdomineque supra, hirsutis; fulvo-aureis.

Apis fulva hirsuta, nigra ; thorace, abdomineque, fulvis. Schrunk. Enum. Ins. Austr. n. 805.

Lin. Syst. Nat. ed. Gmel. p.2786. n.133.

Vill. Ent. Eur. 3. n. 120.

Apis vestita atra; thoracis abdominisque dorso, ferrud gineo-hirtis.

Fab. Ent. Syst. Em. n. 65.

Apis aurea atra; thorace ct abdomine supra, pilis fulvoaureis, hirsutis.

Marsham. M.S.

(i) Tab. 4. **. c. fig, 13. a.

FIG. 


\section{MELITTA. (**. c.)}

FIG. Schaff: Icon. tab.32. fig. 3 .

Apis vestita. Panzer. Fn. Ins. Germ. Init. n.55. tal. 9. Apis vulpina. Christii Hymenopt. p. 161. tab.12. fig.13.

MUS. D. Marsham, Haworth, $M^{c}$ Leay, Trimmer, Lathlury, Sowerby, Kirby.

Long. Corp. Lin. $6 \frac{1}{2}$.

Hab. Barhamiæ sed rarior. In floribus hortorum Aprile et Maio circa Londinum frequens. D. Marsham.

DESCR. Acul.

CORPUS aterrimum, subhirsutum.

Caput. Vertex calvus. Antennce capite longiores, nigræ.

Truncus. Thorax hirsutie densâ, ferrugineẩ vestitus. Squamulce ferrugineæ. Ala hyalinæ, apice obscuriores; nervis ferrugineis, interioribus duobus nigris. Pedes atri, pilosissimi.

АвдомеN ovale, depressum, tergo pilis densis, fulvo-aureis, quasi per fascias hirsutissimo. Ani Fimbria pallidè flava. Venter convexus, segmentis margine atro-hirtis.

This is one of the most elegant of our English species of this genus, the deep orange of the thorax, and of the upper side of the abdomen, forming a most striking contrast with the intense black of the rest of the body. Led by the single circumstance of the thickness of its hirsuties, for I think there can be no doubt of this being his Apis fulva, Schrank has placed this amongst the Bombinatrices, as he has also Apis rufa, Lin., and Apis pilipes, Fab., but a very short examination would convince 
any entomologist that these are altogether distinct from that family. This is also the $A$. vestita of Fabricius and Panzer, and the latter has given a very accurate figure of it. Christius has likewise figured it under the name of Apis vulpina, and my friend Mr. Marsham has described it under that of A. aurea: his name I should have retained, as extremely apt, had not Schrank's had a prior claim.

Clarkellu.69. M. atra, hirsuta; thorace, pedibusque posticis, fulvis.

FIG. Apis icterica. Christii Hymenopt. p. 190. tal. 16. fig.9? MUS. D. Clark, Marsham, Trimmer, Francillon, Kirly.

Long. Corp. Lin. 6.

Hal. Haud infrequens apud Perry Wood, juxta Worcester, D. Bracy Clark. Capta sæpius a D. J. Trimmer prope Londinum.

DESCR. Acul.

CORPUS atrum, hirsutum.

Caput. Vertex calvus. Occipitis pili flavescunt. Antenna vix capite longiores, nigræ.

Truncus supra hirsutie fulvo-flavâ vestitus. Squamulce nigræ. Alce subhyalinæ, apice paulò obscuriores ; nervis, exceptis crassioribus duobus nigris, ferrugineis. Pedes atri, pilosi, tarsis quatuor anticis fuscis. Tibia Tarsique postici fulvi. Scopa fulvo-aurea. Scopulce ferrugincæ.

ABDOMEN ovatum, per fascias supra et infra atro-hirsutum. 
In honorem D. Bracy Clark, Oestrorum monogra phi accuratissimi, nomen, dedi.

Mr. Bracy Clark, author of a most ingenious paper upon the genus Oestrus in the third volume of the Transactions of the Linnean Society $(k)$, sent me this Melitta, for the Apis bicolor of $\mathrm{Fa}-$ bricius. But that, as we have seen above, is only the male of $M$. thoracica; from this $M$. Clarkella is sufficiently distinguished by the hairiness of its abdomen, and the colour of its posterior legs. Christius has given us the figure of an Apis, which he names $A$. icterica, in colour much resembling our insect; but it is much smaller, and of a dif- ferent form, I have therefore considerable doubts about its identity.

70. M. nigra, grisescente-subhirsuta; thorace ab-Smithella domineque hirsutis, fulvescentibus, segmentis margine albidioribus.

FIG. Apis pilipes. Panzer. Fn. Ins. Germ. Init. n.7. tab.13. MUS. D. Smith, Marsham, Trimmer, Francillon, Kirby.

Long. Corp. Lin. $5 \frac{1}{2}$.

Hab. Barhamix, in Salicum amentis masculis frequens anno 1799.

DESCR. Acul.

CORPUS nigrum, pube grisescenti。

(k) I would be understood to say this with the exception of his note containing the account of Oestrus Cuniculi : the opinion advanced in which, as militating against a superintending Providence, I think highly objectionable.

VOL. II.

CAPUT 
CAPUt. Vertex calvus. Facies posticè pilis nigricantibus. Antenne nigræ.

TRUNCUS supra hirsutie, haud densâ, sordidè fulvà. Squamula nigræ. Alce hyalinæ apice paulò obscuriores ; nervis ferrugineis, duobus crassioribus nigris. Pedes grisescente-pilosi. Tilice posticæ scopa versicolori, sub luce pallidâ, certo situ fuscescente. Scopulac ferrugineæ: Flocculus pallidus.

Ав DомеN subellipticum, subdepressum, hirsutum, hirsutie pro situ nunc fuscâ, nunc fulvescenti, segmentis margine pallidis. Venter convexus, nitidus, segmentis infra marginem hirtis, marginis ciliâ brevissimâ, densâ, pallidâ.

In honorem D. Præsidis Societatis Linnæanæ, Botanicorum principis, tum et in Entomologid peritissimi, nomen dedi.

Panzer, in an early number of his Faunce insectorum Germanice initia, had figured the insect here described as the Apis pilipes of Fabricius; but afterwards he discovered that this was a mistake; and gives the real $A$. pilipes, but without substituting another name for this.

tridenta- 71. M. nigra, fulvo-subhirsuta; labio tridentato; ta. digitis testaceis.

MUS. Kirly.

Long. Corp. Lin. 5 .

Hab. Capta semel apud Melton juxta Woodbridge, Suffolciæ; Augusto exeunti 1799.

DESCR. 
DESCR. Mas.

CORPUS nigrum, fulvo-pubescens.

CAPUT. Facies infra antennas hirsutie densâ, flavescenti barbata. Maxille forcipatæ. Labium, a ventre conspectum, dentes tres exhibet, lateralibus minoribus, acutis, intermedio f. tuberculo, majori obtuso, antrorsum excavato. Antennce capite longiores, nigræ, subtus piceæ.

Truncurs. Thorax hirsutie rufó-fulvâ obsitus. Squamula nigræ. Ala hyalinæ, apice nigricantes; nervis ferrugineis, crassioribus duobus nigris. Pedes pallido-hirti, digitis testaceis.

Ав ромеn subovale, hirsuto-fulvum, segmentis margine pallidioribus.

I have some suspicion that this may be the male of M. Smithella ; but as I never saw but one specimen of it, and that taken in another district, I have not ventured to put them together.

72. M. atra, albido-villosa ; maxillis basi denticulodenticuarmatis; labio tridentato; abdomine strigis tribus albis.

MUS. Kirly.

Long. Corp. Lin. $4 \frac{2}{3}$.

Hab. Barhamiæ rarissima.

DESCR. Mas.

CORPUS atrum, pube albidâ incanum.

CAPUt hirsutum, trunco latius. Maxille forcipatæ, capite breviores, basi denticulo acuto K 2

armactre, 
$\operatorname{armatx}(l)$. Labium, a ventre visum, tridentatum, dentibus lateralibus acutis, intermedio majori, truncato, antrorsum excavato $(m)$. Antenna capite longiores, subtus piceæ.

Truncus. Squamula nigræ. Ala subhyalinæ, apice nigricantes; nervis ferrugineis, costali interiore nigro. Pedes griseo-hirti, digitis testaceis. Plantee posticæ obscurè ferrugineæ. Scopulce fulvæ.

Ав DомEN lanceolatum, acutum, atro-pilosum ; basi, segmentisque tribus intermediis margine, villoso-albis. Anus cinerco-pilosus. Venter grisescente-subhirtus.

Far. $\beta$ verticis, thoracisque hirsutie nigricanti ; alis apice nigris, nervis piceis; pedibus rufescente-hirtis.

This is quite distinct from the preceding species, although the lip in both is distinguished by the same peculiarity.

nigriceps.73. M. atra; thorace fulvo; abdomine fasciis tribus villo-rufescentibus.

MUS, Kirby.

$$
\text { Long. Corp. Lin. } 5 \frac{1}{2} \text {. }
$$

Hal. Barhamice. Mas in Sulicum amentis, Aprili ineunte, 1800.

DESCR. Acul.

CORPUS atrum, pube nigricanti.

Caput trunco angustius, atro-pubescens. $A n-$
(') Tab. 4,**. c. fig. 5, a.
(m) Ibid. fig. 18. 


$$
\text { MELITTA. (**. c.) }
$$

ienne nigræ, capitis longitudine. Vertex calvus, occipitis pilis fulvescentibus.

Truncus. Thorax hirsutie, densâ admodum, rufo-flavâ tectus. Metathorax villis pallidè flavis. Squamulce ferruginæ. Alce hyalinæ, apice paulò obscuriores, nervis fuscescentibus. Pedes atri, pilosi. Femorum barba sordidè pallida. Digiti picei.

Ав DомеN ovale, subdepressum; basi, segmentisque tribus intermediis fasciâ, villoso-rufescentibus. Ani Fimbria atra. Venter convexus. Maris Corpus grisescente-hirtum. Caput atrohirsutum. Antenna thorace breviores. Thorax subgriseus, $\int$. pube sordidè rufâ translucente nigredine corporis. Ale nervis flavescentibus. Abdomen lanceolatum, pilosulum, segmentis margine densiùs villosis.

Obs. Mas nimis affinis M. bimaculatce, sed desunt macula ventrales rufa. An hic referendus?

The insect, which I have given as the male of this species, very much resembles it; yet not sufficiently to take away all doubt of their identity. If distinct, it ought to precede or follow M. bimaculata, of which, after all, it may be only a variety.

74. M. nigra, cinerascente-villosa; thorace flave-ruftarsis, scenti; abdomine segmentis margine albidis ; antennis subtus, digitisque, rufis.

MUS. Kirby.

Long. Corp. Lin. 5.

Hal. Barhamiæ rarissima.

K 3

DESCR。 
DESCR. Acul.

CORPUS nigrum, cinerascente-villosum.

CAPU T. Facies villis albidis incana. Vertex calvus. Occipitis pili flavescunt. Antennce subtus rufo-fulvæ, basi nigræ.

Truncus supra pube brevi, densâ, pallidè flavâ, tectus. Squamula nigræ. Ale subhyalinæ, nervis piceis. Pedes cinereo-pilosi. Palma fuscæ. Tilbia posticæ scopà pallidâ. Digiti omnes testacei. Scopula fulvæ.

Aв Domen subovale, cinereo-subhirsutum, segmentis margine albicantibus. Ani Fimbria cinerascens. Venter convexus, nitidus, segmentis margine hirtis.

fuscipes. 75. M. nigra, pallido-subvillosa; thorace fulvo; abdomine segmentis margine albidis; tibiis posticis scopâ fuscâ.

MUS. D. Lathbury, Kirly.

Long. Corp. Lin. 5.

Hal. Barhamiæ rarissima.

DESCR. Acul.

CORPUS nigrum, pallido-villosum.

CAPU t subvillosum. Antennce nigræ, articulis extimis subtus rufo-piceis. Macula sericeocinerea, nisi sub lente et a latere vix conspicua, Verticem utrinque apud oculos signat.

Truncus. Thorax pube fulvâ obsitus. Metathorax pallido utrinque villosissimus. Squamulce testacex. Alce subhyalinæ, apice obscuriores? 
MELITTA. (**. c.)

scuriores, nervis piceis. Pedes fusco-pilosi, certo tamen situ pallescunt pili. Femorum barba albida. Tibia posticæ scopâ fuscâ undique obsitæ.

Aв domen subellipticum, tergo depressiusculo, pilis brevissimis vix conspicuis, rigricantibus consito, basi pallido-villoso, segmentis tribus intermediis margine tomentoso-albis. Ani Fimbria fuscescens. Venter convexus, nitidus, segmentis albido-ciliatis.

This insect and the preceding are liable to be confounded, since, upon a cursory view, there appears to be very little difference between them; but if they be more closely examined, they will be found very distinct. The antennæ of $M$. fuscipes are entirely black, except only the under side of the two last joints ; its head is less hairy, and the hairs of the legs, and the scopa, which in the present family, in that respect, are not subject to vary, are brown. The vertex, in both these insects, is distinguished by a pale downy spot on each side adjoining to the eyes, scarcely to be discovered without the assistance of a magnifier, which seems desigued to prevent the antennæ from receiving injury by friction: a circumstance which is observable in many other species.

76. M. atra, pallido-subvillosa; abdomine segmen- Listerella tis margine albidis; thoracis disco subpiloso, nigro. 
MUS. D. Marsham, Haworth, Souerly, Trimmer, Kirly,

Long. Corp. Lin. $4 \frac{2}{3}-5 \frac{1}{2}$.

Hab. Barhamiæ in floribus, maximè Syngenesice.

DESCR. Acul.

CORPUS atrum, pallido-viilosulum.

Capur pube cinerascenti. Vertex calvus. Occiput pilis atris. Antennce subtus fulvæ, basi nigræ.

TRUNCU s supra pilis raris, atris, limbo villis densis, pallidis. Metathorax utrinque pallido-villosissimus. Squamule nigræ. Alce subhyalinæ, apice nigricantes, nervis fuscescentibus. Pedes nigri, pallido-pilosi. Scopula fulvo-aureæ. Digiti rufi.

Aв DомеN suborale, tergo depressiusculo, atro, pilosulo, basi, apiceque cinerascenti, segmentis margine latè villoso-albidis. Venter convexus, nitidus, segmentis cinereo-ciliatis.

$\operatorname{Var} . \beta$ pedibus, ventreque, piceis.

fulvicrus. 77. M. nigra, grisescente-villosa; abdomine fasciis tribus pallidis; tibiis posticis scopâ fulvâ.

MUS. D. Marsham, Smith, Latham, Hau:orth, McLeay, Lathbury, Sowerby, Trimmer, Francillon, Kirly.

Long. Corp. Lin. $4 \frac{1}{2}-5 \frac{x}{4}$.

$H a l$. Barhamiæ, in floribus Syngenesia, maximè Jacolea, tempore autumnali haud infrequens. Mas, ineunti Aprile, declivia circum arida irrequietus volitat. Recens insectum allium spirat.

DESCR. Acul.

CORPUS nigrum, grisescente-villosum.

CAPUT 
MELITTA. (**. c.)

$\mathrm{C}_{\text {A } \mathrm{PUT}}$ Facies hirsutie densâ vestita. Occipitis pili nigri. Antenna capitis longitudine, nigræ. Truncus. Thorax pube rarâ admodum. Squamula piceæ. Ale hyalinæ, apice nigricantes; nervis ferrugineis, duobus crassioribus nigris. Pedes rufescente-pilosi. Tỉice posticæ scopâ fulvâ. Scopulce fuscæ.

Aв Dомen ovatum, latum; tergo glabriusculo, punctulatissimo, punctulis levissimè impressis, basi villosulo, segmentis tribus intermediis margine tomentoso-pallidis. Ani Fimbria atra. $V$ enter hirtus, anum versus potissimum.

$V$ ar. $\beta$ corporis pube cinerascenti.

Maris Facies hirsuto-nigricans. Antennce thorace breviores. Abdomen lanceolato-ovatum, segmentis tribus anticis griseo-hirsutulis, intermediis quatuor margine villoso-grisescentibus.

Var. $\beta$ abdominis segmentis margine villosoalbidis.

78. M. nigra, supra fulvo-pubescens; abdominelanifrons. ovato, basi fulvo-villoso; segmentis apice pallidioribus.

MUS. D. Haworth.

$$
\text { Long. Corp. Lin. } 5 .
$$

Hab. in Angliâ. Hanc unicam vidi.

DESCR. Mas.

CORPUS nigrum, subtus pallido-villosulum, pube densâ fulvâ vestitum.

Caput, 
Caput. Facies flavescente valde hirsuta. Ge. narum barba longa, densa. Antenne thoracis longitudine, nigræ, subtus picex.

Truncus. Squamulce fulvæ. Ala hyalinæ, nervis nigricantibus. Pedes nigri, hirti, tibiis, quàm in hâc familia plerumque maribus mos est, majoribus. Digiti testacei.

Ав домеn ex oblongo ovatum, nigrum, pubescens; segmentis duobus anticis pube fulvâ tectis, proximis tribus margine fulvescentepallidis.

sontigua. 79. M. atra, cinereo-villosa; abdomine segmentis margine villoso-albis.

MUS. Kirly.

Long. Corp. Lin. $4 \frac{2}{3}$.

Hab. Barhamiæ e rarioribus una.

DESCR. Mas.

CORPUS atrum, villoso-cinerascens.

CAPU T trunci ferè magnitudine. Facies hirsutogrisescens. Labii tuberculum elevatiusculum, truncatum. Antenne thorace breviores.

Truncus. Squamule piceæ. Ale subhyalinæ, apice obscuriores; nervis rufo-piceis, crassioribus duobus nigris. Pedes hirti.

АвдомеN ovatum, cinerascente-hirsutulum; segmentis ultimis margine villoso-albis.

This spccies a good deal resembles variety $\beta$ of the male of $M$. fulvicrus; but the hirsuties of its 
MELITTA. (**, c.)

face is grisescent, and its abdomen is shorter and more ovate.

So. M. nigra, cinereo-villosa; abdomine ovali;pulescens. labio subcornuto.

Apis pubescens corpore cinereo-pubescente, immaculato.

Fal. Ent. Syst. Em. n. 95.

Lin. Syst. Nat. ed. Gmel. p. 2773. n.69.

Vill. Ent. Eur. 3. n.61.

MUS. Kirly.

Long. Corp. Lin. 3.

Hal. In Suffolciâ, semel tantummodo lecta.

DESCR. Mas.

CORPUS nigrum, cinereo-villosum.

CAput trunco majus. Antennce thorace breviores, subtus piceæ. Labii tuberculum elevatiusculum.

Truncus. Squamule nigræ. Alce hyalinæ, apice paulò obscuriores, nervis nigricantibus. Pedes cinereo-hirti.

A В DOMEN ovale, cinereo-hirsutulum, segmentis margine albidioribus. Venter convexus, hirtus, segmentis ciliâ brevi, albidâ marginatis.

This little Melitta agrees so well with Fabricius's description of his Apis pubescens, that I have no doubt of its being that insect. It is extremely rare, and much smaller than any of the preceding males.

81. M. atra, cinereo-subpubescens; abdomine seg-hemormentis posticis utrinque margine albis; ano rhoidalis. $^{2}$ ferrugineo. 
Andrena hcemorrhoidalis nigra, ano ferrugineo.

Fal. Ent. Syst. Em. n. 25.

Vill. Ent. Eur. 3. Apis, n.74.

Apis dichroa. Lin. Syst. Nat. ed. Gmel. p.2792. n.188,

MUS. D. Latham, Francillon, Kirly.

Long. Corp. Lin. 7-8.

Hab. in $\Lambda$ ngliâ, a D. Latham bis capta.

DESCR. Acul.

CORPUS atrum, pube cinerascenti.

Caput densius barbatum. Vertex utrinque ad oculos maculâ sericeo-flavescente, nisi a tergo et sub lente vix conspicuâ, ornatus. Antenna capitis longitudine, nigræ, subtus rufo-piceæ. Truncus supra glabriusculus. Thorax nitidus, punctulatus, anticè lineis tribus obsoletis notatus. Squamulc ferrugineæ. Alce testaceæ, apice obscuriores, nervo costali interiore nigro. Pedes nigri, rufo-pilosi. Femorum lana pallida. Tibice posticæ scopâ rufâ, Digiti testacei. Scopula ferrugineo-auratæ.

Авдомen ex oblongo subellipticum, glabrum, lucidum, piceo-nigrum; segmento tertio et quarto margine utrinque albo-ciliato. Ani Fimbria densa, ferruginea.

Var. $\beta$ scopâ supra flavescenti, subtus albidâ.

Maris Nasus luteo-albidus, punctulis duobus nigris. Truncus supra grisescente-villosus. Abdomen grisescente-villosulum.

This fine insect, which has been taken in England, the aculeate by Dr. Latham, and both sexes by Mr. Francillon, is one of the largest of the ge- 
nus. It is, I think, beyond a doubt, the Andrena hacmorrhoidalis of Fabricius. The synonym of Panzer belongs to a Melitta, I shall describe hereafter. Christius has figured two insects as synonymous with this: the one a Bombinatrix, the Apis arbustorum, Fab., and the other $M$. albicans, described above $(n)$

82. M. nigra, cinereo-subpubescens; abdominechrysosnitido, fasciis interruptis albidis; ano, tarsis, ${ }^{\text {cles. }}$ tibiisque posticis, testaceis.

MUS. D. Marsham, Haworth, Lathlury, Trimmer, Sowerly, Kirly.

Long. Corp. Lin. $4-4 \frac{\mathrm{T}}{2}$.

$H a b$. Barhamiæ, in floribus haud rara, tempore vernali copulans.

DESCR. Acul.

CORPUS nigrum, cinereo-subpubescens.

Caput. Antenna nigræ, subtus rufo-fulvæ.

Truncus. Thorax utrinque lineolâ abbreviatâ exaratus. Squamule testaceæ. Alce testaceæ, iricolores, apice nigricántes. Pedes piceo-nigri, pallido-pilosi; femorum posticorum barbâ et flocculo albidis. Tarsi omnes, Tibiceque posticæ, testacei. Scopa argenteo-albida. Scopulce fulvo-aureæ.

Авдомеn subovale, fusco-nigrum, tergo depressiusculo, lucido, glabro, segmentis tribus intermediis margine albo-ciliatis, anticis duobus interruptè. Ani Fimbria pallidè aurea. $V$ enter convexus.

(u) Hymenopt. p.132, tab. 9. fig. 2. \& ₹. 100. tab. 16. fig. 8. 
MELITTA. (**. c.)

Maris Corpus angustum, albido-villosum. Caput trunco latius. Facies anticè hirsuta. Nasus carneus, utrinque punctulo nigro notatus. Occipitis pili cinerei. Antenne thorace breviores, nigræ. Thorax cinereo-subvillosus. Tibia posticæ nigræ, apice testaceæ. Abdomen lineari-lanceolatum, tergo convexo, albido-pilosulo, segmentis intermediis margine utrinque obsoletè ciliatis. Venter hirtulus, segmentis posticis fimbriâ nitidâ, pallidè aureâ, nisi a latere vix conspicuâ, ciliatis.

Var. $\beta$ tibiis posticis testaceis, liturâ subannulari nigricanti.

Obs. Habitus et statura pracedentis, sed multoties minor.

dorsata. 83. M. nigra, cinereo-subvillosa; thorace fulvo; abdomine fasciis tribus albis, anticâ interruptâ ; tarsis rufis.

MUS. Kirby.

Long. Corp. Lin. $4 \frac{\pi}{2}$.

$H a b$. In Suffolciâ, semel tantùm lecta.

DESCR. Acul.

CORPUS nigrum, pube cinerascenti.

Caput. Antennce nigræ, capite longiores.

Truncus supra pube, brevi admodum, fulvâ obsitus, limbo confertiùs. Metathorax utrinque pallido-villosus. Squamulce ferruginex. Alce testaceæ, iricolores, apice obscuriores. Pedes picei, pallido-pilosi; digitis omnibus, plantisque. 
MELITTA. (**. c)

plantisque posticis, rufis. Tibice posticæ apice rufæ, scopâ pallidâ. Scopula fulvæ.

АвромеN subovale, tergo glabro, segmentis tribus intermediis margine albo-ciliatis, antico interruptè. Ani Fimbria cinerea. Venter convexus, cinereo-hirtus, maximè anum versus.

This species is easily confounded with that which precedes it, but if they are carefully compared it ivill be found to be distinct. The antennæ are entirely black; the pile of the upper side of the trunk is shorter and tawney; the feet are piceous; and only the digiti and posterior plantæ are red. The anal fringe likewise is paler, the first only of the abdominal fasciæ is interrupted, and the under side of the abdomen is more hairy.

84. M. atra, cinereo-subvillosa; abdomine seg- wilkella. mentis intermediis utrinque margine albis; plantis, tibiisque posticis, rufis.

MUS. Kirly.

$$
\text { Long. Corp. Lin. } 5 \frac{3}{4} \text {. }
$$

Hab. in Angliâ prope Londinum, a D. Trimmer semel capta et mihi transmissa.

DESCR. Acul.

CORPUS atrum, cinereo-subvillosum.

Caput. Antenne nigræe, subtus picee.

Truncus supra glabriusculus. Squamula ferrugineæ. Alse testaceæ, nervo costali interiore nigro. Pedes nigri, rufescente-pilosi. Femorum barba pallida.- Plantce, Tibiaque postica, rufac, 
MELitTA. (**. c.)

rufæ. Palmce nigræ. Scopa flavescens. Scopula fulvæ. Digiti rufo-picei.

АвDомEN ex oblongo subovatum, segmentis tribus intermediis utrinque margine albo ciliatis. Ani Fimbria pallida. Venter convexus, cinereo-pubescens.

In honorem D. Wilks Angli, Entomologi prastantis, et Lepidopterorum pictoris eximii, nomen imposui.

M. Wilkella is considerably larger than either of the preceding species, its thorax is less hairy, its digiti are rufo-piceous, and its abdomen is of a different form, being proportionably wider at its base; in most other respects it is very similar to them.

proxima. 85. M. atra, cinereo-subpubescens; thorace grisescenti; abdomine utrinque strigis tribus albis; scopâ pallidâ niteriti.

MUS. D. Sowerly, Kirly.

Long. Corp. Lin. $4 \frac{x}{2}$.

Hal. Barhamix, rarior tamen.

DESCR. Acul.

CORPUS atrum, cinereo-villosum.

CAput. Facies infra antennas densè satis pubescens. Antenna nigræ, capite longiores.

Truncus. Thorax pube rariori, subgrisea consitus. Metathorax confertiùs villosus. Squamulce piceæ. Alce subhyalinæ, apice nervisque, nigricantibus. Pedes pallido-pilosi; tibiis posticis 
posticis scopâ pallidâ, argenteo-nitidâ. Digiti articulis extimis ferrugineis. Scopulce nigricant.

Ав DоMEN subovatum, lucidum, segmentis tribus intermediis lateribus margine albo-ciliatis. Ani Fimbria sordidè pallida. Venter convexus, cinereo-subhirtus.

$V$ ar. $\beta$ alarum nervis, plantis, scopulisque, rufis; abdomine segmentis intermediis margine albo-ciliatis, antico interruptè.

The hirsuties of the thorax of $M$. proxima is nearly of the same colour with that of $A$. mellifica, which Linneus has called subgrisea. Its wings have no testaceous hue, and its pale scopæ, in certain lights, glitter like silver : circumstances which sufficiently distinguish this insect from those which precede it. Variety $\dot{\beta}$ seems intermediate between $\alpha$ and M. Wilkella.

86. M. atra, nitida, albido-subvillosa; frontis an-Coitana. gulis, nasoque, albis.

MUS. Kirly. Long. Corp. Lin. $3 \frac{\pi}{2}$.

Hab. in Angliâ, a D. J. Coyte, entomologo Gippovicensi, mihi transmiss?.

DESCR. Mas.

CORPUS atrum, nitidum, albido-subpubescens. CAPUT. Nasus, atque anguli frontis, carneoalbidi, ille punctulis cluobus nigris notatus. Antenna thorace breviores nigræ.

Truncus. Squamule piceæ. Ala subhyalinæ, nervis nigris. Pedes hirti, digitis ferrugineis. TOL. II. 
Ав оомеN lanceolatum, convexum, albido-pilosulum, segmentis apice obscurè rufescentibus. Venter albido per fascias hirtus.

A coloured nasus now and then distinguishes the males in this and the following genus. This we have seen before, in the instances of $\boldsymbol{M}$. cingulata, hamorrhoidalis, and chrysosceles, as well as in the second family. I presume it is also a sexual character in the present and the following species. This has been taken only by my ingenious friend, the Rev. James Coyte of Ipswich, by whose name I have called it, and whose cabinet contains many other very rare insects.

latialis. 87. M. nigra, pallido-villosa; thorace fulvescenti; facie anticè albidâ ; abdomine segmentis margine utrinque pallidis.

MUS. D. Marsham, Trimmer, Kirly.

Long. Corp. Lin. $5 \frac{1}{2}$.

Hal. in Angliâ, capta sæpius prope Londinum, semeĺ juxta Norvicum.

DESCR. Mas。

CORPUS nigrum, pallido-villosum.

CAPut trunco latius. Os albido-barbatum. Facies posticè cinereo-villosa, anticè carnea, naso punctulis duobus nigris. Antennce nigræ, thorace breviores.

TRUncus. Thorax fulvescente-pubescens. Squamulce testacex. Alce testaceæ, apice, nervoque costali interiore, nigricantibus. Pedes pallidohirti, digitis ferrugineis. Scopulce fulvo-aureæ.

ABDOMEN 
MELITTA. (**. c.)

Ádomen lanceolato-ovatum; tergo ex pilis densis fusco-cinereo, segmentis utrinque margine albidioribus. Venter basi cinereo-subhirtus, segmento penultimo fimbriâ densâ, flavescenti.

$\operatorname{Var}_{\boldsymbol{\beta}} \boldsymbol{\beta}$ thorace rufo; abdominis hirsutie grisescenti.

$\gamma$ facie anticè flavâ.

88. M. nigra, pallido-villosa; thorace, tarsisque ru-Lewinel fescentibus; abdomine segmentis intermediis ${ }^{l a}$. utrinque strigâ albidâ.

MUS. D. Marsham, Latham, Haworth, Trimimer; Lathbury, Kirby.

Long. Corp. Lin. $3 \frac{3}{4}$.

Hal. Barhamiæ, in floribus tempore vernali haud rard.

DESCR. Mas.

CORPUS nigrum, pallido-villosum:

CA pux. Facies hirsuto-subrufa. Antennex fere thoracis longitudine, nigra.

Truncus supra hirsuto-rufescens. Squamule nigræ. Ale subbhyalinæ, iricolores, apice obscuriores; nervis testaceis, costali interiore nigro. Pedes grisescente-hirti, tarsis omnibus; tibiarumque posticarum apice; tèstaceis.

AвDOMEN ovato-lanceolatum, fusco-nigtim; pilosulum, basi et apice grisescente-villosum s segmentis intermediis margine utrinque albos ciliatis: Venter subhirtus.

89. M. atra, cinereo-villosa; abdomine ơato segisojatulit mentis margine albidis. 
MUS. D. Marsham, Sou'erly, Trimmer, Kirly.

Long. Corp. Lin. 4.

Hab. Barhamix, in collibus arenosis frequens mense Maio, 1800.

DESCR. Acul.

CORPUS atrum, cinereo-villosum.

$\mathrm{C}_{\mathrm{A}} \mathrm{PU}$ T. Facies infra antennas hirsuto-grisescens. Antennce thorace breviores, piceo-nigræ.

Truncus. Thorax pube, haud densâ, subgriseâ obsitus. Squamula piceæ. Alce hyalinæ, iricolores, apice obscuriores; nervis nigricantibus, anastomosi pallidâ. Pedes cinereo-hirti. Scopula fulvæ.

AвDOMEN ovatum, pilosulum, segmentis margine albo-ciliatis, anticis interruptè. Venter cinerco-hirtus; segmentis margine fimbriâ flavescente-nitenti ciliatis.

larlata. 90. M. nigra, lutecenti-villosa; abdomine subovato; segmentis margine membranaceis, albidociliatis.

MUS. D. Banks.

Long. Corp. Lin. $4 \frac{1}{2}$.

$H a b$, in Angliâ.

DESCR. Mas.

CORPUS nigrum, pube lutescenti.

$\mathrm{C}_{\mathrm{APUT}} \mathrm{T}$ villis pallidis longiùs barbatum. Facies hirsuto-lutescens.

Truncus. Alce subhyalinæ; nervis, excepto costali interiore nigro, testaceis. Pedes albidohirti, digitis rufescentibus. 
AвдомеN fusco-nigrum, pallido-subvillosum ; segmentis anticis margine membranaceis, intermediis tribus albido-ciliatis, ultimis pilosonigricantibus.

This insect, in the form of its abdomen, somewhat resembles $M$. ovatula; its head, however, is extremely hairy, the margin of the anterior dorsal segments of the abdomen is membranaceous. The only specimen that I have ever seen of it is in the rich cabinet of Sir J. Banks.

91. M. atra, hirsuto-canescens; abdomine lævi, barlilalanceolato; facie anticè barbâ densâ argenteâ. ${ }^{\text {bris. }}$

MUS. D. Marsham, Sowerby, Kirly,

Long. Corp. Lin. $4 \frac{1}{4}$.

Hab. Barhamiæ in floribus mense Maio, e rarioribus una.

DESCR. Mas.

CORPUS atrum, hirsuto-incanum.

CAPUT. Facies anticè barbà densà, longấ, argenteo-nitidâ ornata. Maxille forcipatæ. Antennce thorace breviores, nigræ.

Truncus. Thorax hirsutie cinerascenti. Squamulce nigræ. Alce hyalinæ, apice paulò obscuriores; nervis piceis, anastomosi majusculà. Pedes albido-hirti. Scopulce pallidx. Digiti ferruginei.

Ав Dо ín lanceolatum, acutum, "piloso-subincan $\mathrm{m}$, læve. Venter pilosulus, segmentis fimbriâ brevì, 'denisá, argentèâ, " ciliàtis.

$$
\text { L } 3
$$

This 
This little insect is remarkable for the silver pile which is, as it were, combed over its mouth, and for the long hoary hair with which its body, the abdomen excepted, is thickly vested on all sides. In shape it resembles the Andrena nitida of Panzer $(0)$, from which, however, it is very distinct.

larlatu- 92. M. atra, albido-villosa; abdomine subovali, ia. punctulato; segmentis intermediis margine utrinque albis.

MUS. D. Marsham, Trimmer, Kirby.

Long. Corp. Lin. $4 \frac{\pi}{4}$.

Hal. Barhamiæ rarior.

DESCR. Mas.

CORPUS atrum, albido-villosum.

CAPUt hirsutum. Antenne thorace vix breviores, nigræ, nitidæ, articulis subarcuatis.

Truncus. Thorax cinereo-pubescens. Squamulce nigræ. Alce subhyalinæ, apice nigricantes ; nervis, costali interiore nigro excepto, ferrugineis, Pedes albido-hirti. Scopula pallidæ.

АвDомEN ex lineari-subovale; tergo punctulis creberrimis levissimè impressis, nisi sub lente vix conspicuis, perseminatum, segmentis tribus intermediis utrinque ciliâ marginali albâ, basi anoque villoso-albidis. Venter grisescente subhirtus, segmentis ultimis cilia brevi, flavescenti, fimbriatis.

(o) Fn. Ins. Germ. Init. n. 56, tab. 2.

93. M. 
93. M. atra, cinereo-villosa ; abdomine subovato, Collinnitido; segmentis posticis margine albidis. sonana.

MUS, Kirly.

Long. Corp. Lin. $3 \frac{1}{2}$.

Hab. In Angliâ, prope Norvicum capta Junio mense 1799.

DESCR. Mas,

CORPUS atrum, cinereo-villosum.

CAput trunco latius. Oculi prominuli. Antennee capite longiores, subtus fusco-nigræ.

Truncus. Squamula nigræ. Alae subhyalinæ; nervis ferrugineis, costali interiore nigro. Pedes albido-̧hirti. Scopula flavescunt.

Ав DOMEN ovato-lanceolatum, aterrimurn, nitidum; segmentis secundo et tertio utrinque, posticis margine toto, niveo-ciliatis. Anus ipse pallido-villosus. Venter pilosulus, segmentis margine pilis luteo-nitidis ciliatis.

This is not very unlike M. barbatula, but it is not much more than half its size, and its abdomen is of a different form.

94. M. cinerea-subpubescens; thorace rufo; me-comlinatathorace utrịnque fimbriâ pallidâ; abdomine ${ }^{t a .}$ fasciis tribus, interruptis, albidis.

FIG. Apis combinata. Christii Hymen. p.187. tal.15. fig.9.

MUS. D. Marsham, McLeay, Haworth, Trimmer, Sowerly, Lathbury, Kirly.

Long. Corp. Lin. $3 \frac{3}{4}-4 \frac{1}{2}$.

Hab. Barhamiæ in floribus frequentissima.
I 4
DESCR. 
DESCR. Acul.

CORPUS nigrum, pube cinereâ.

Caput. Facies apud oculos confertius villosa, Occipitis pili albidi. Antennce nigræ.

Truxcus. Thorax pube rufescenti consitus. Metathorax utrinque villis densis, incurvis, luteo-pallidis fimbriatus $(p)$. Squamulc picex. Ala subhyalinæ, apice paulò obscuriores; nervis flavis, costali interiore nigro. Pedes pallidohirti, digitis omnibus, plantisque posticis, rufis. Scopula fulvæ.

Ав Dомеn subellipticum, tergo depressiusculo, glabro, punctulatissimo; segmentis tribus intermediis, margine utrinque albo-ciliatis. Ani Fimbria fulvescens. Venter convexus segmentis margine cinereo longiùs ciliatis.

Var. $\beta$ abdomine fasciâ posticâ absolutâ.

$\gamma$ abdomine segmentis tantùm duobus in termediis utrinque margine albis.

$\delta$ tarsis quatuor, tibiisque posticis apice, rufis; abdomine fasciâ posticâ absolutâ. $\varepsilon$ corporis pube grisescenti, thoracis ferrugineâ; alis apice obscurioribus nervis testaceis; abdomine ovato, fasciis tribus tomentoso-pallidis, anticis duobus interruptis; digitis quatuor anticis fusco-nigris. An eadem ?

Maris Corpus angustum, pube grisescenti ; Antennce thoracis fere longitudine. Alce apice (p) Tab. 4.**. c. fig. 9. $a a$.

nigricantes. 
nigricantes. Aldomen ovato-lanceolatum, nitidum, basi rufescente villosulum; segmentorum ciliâ pallidâ.

Var. $\beta$ plantis omnibus nigris, corporis pube cinereâ.

This species varies much, but all the varieties here given are distinguished by a thick incurved fringe on each side of the metathorax, which these little creatures load with pollen. I am not clear, however, that $\varepsilon$ is not distinct. Apis combinata of Christius appears to be a variety of our insect; if so, he has omitted the fringe of the metathorax. The male much resembles $M$. Lewinella, but in that all the tarsi are red.

95. M. atra, supra nudiuscula ; metathorace utrin-nudiuscuque, tibiisque posticis, pallido-lanatis.

MUS. Kirb̄y.

\section{Long. Corp. Lin. 5.}

$H a b$. In Suffolciâ, semel tautùm lecta.

DESCR. Acul.

CORPUS atrum, subtus cinereo-villosum.

CAPU t subvillosum. Oculorum intervallum latissimum. Antenne nigræ.

Truncus. Thorax glabriusculus. Metathorax utrinque pallido-lanatus. Squamulce piceæ. Alce testaceæ, nervo costali interiore nigro. Pedes pallido-pilosi. Scopula fuscæ.

Авдомеn subovale, basi et lateribus pilis longis admodum albidis subvillosum. Ani Fimbria rufescens. Venter per fascias cinereo-hirtus. 
This species, in common with the preceding, possesses the fringe of the metathorax, although not so conspicuously. It wants, however, the dorsal fasciæ which invariably distinguish the abdomen of all the varieties of $M$. combinata, the place of which is supplied by a few long whitish hairs scattered over the base and sides of the abdomen of the insect before us. Its tarsi also are all black, and its thorax bare. This latter circumstance may be only accidental, for this part is very apt to have its hair rubbed off.

allicrus. 96. M. atra, cinereo-villosa; thorace fulvo; abdomine ovato, pilosulo, strigis tribus albis; scopâ versicolori.

MUS. D. Marsham, Trimmer, Lathbury, Kirly.

Long. Corp. Lin. $5-5 \frac{1}{2}$.

Hal. Barhamiæ, capta etiam prope Norvicum, et a D.

J. Trimmer prope Londinum.

DESCR. Acul.

CORPUS atrum, cinereo-villosum.

Caput. Maxilla forcipatæ. Facies posticè grisescente-villosa. Antenne nigræ.

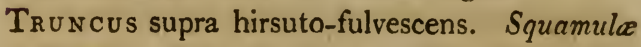
piceæ. Ala subhyalinæ apice paulò obscuriores, nervis nigricantibus. Pedes albido-pilosi. Tibie posticæ scopâ supra nigricanti, subtus argenteo-albida, certo situ versicolori, undique obsitæ.

АвдомеN ovatum, nitidum, albido-pilosum, segmentis tribus intermediis margine albo ciliatis, 
MELITTA. (**. c.)

atis, anticis duobus interruptè. Ani Fimbria fusca. Venter segmentis margine ciliâ densâ, brevi, albâ ciliatiș, pilis longioribus insuper consitis.

$V a r . \beta$ thoracis pube ferrugineâ.

Maris Corpus totum hirsuto-incanum. Antennce thorace breviores. Pedes hirti. Abdomen segmentis ventralibus haud ciliatis.

$V a r . \beta$ adultior, hirsuto-cinereus.

This insect may possibly be the Apis sericea of Christius $(q)$, but in his figure the legs are painted yellow.

97. M. atra, cinereo-subpubescens; abdomine con-connec vexo, nitido; tarsis omnibus, tibiisque posticis, ${ }^{\text {tens. }}$. rufis.

MUS. Kirby.

Long. Corp. Lin. 5.

Hal. Barhamiæ semel capta, iterum a D. Trimmer prope Londinum.

DESCR. Acul.

CORPUS atrum, cinereo-subpubescens.

$\mathrm{C}_{\mathrm{APU}} \mathrm{T}$ apud basin antennarum longiùs et densiùs villosum. Antennce piceæ, scapo nigro. Macula sericeo-pallida, nisi sub lente et a tergo vix conspicua, Verticem utrinque signat.

Truncus. Thorax leviter pubescens. Metathorax utrinque pallido-villosus. Squamula testaceæ. Ala subhyalinæ, apice obscuriores,

(q) Hymenopt. p. 190, tab. 16. fig. 11.

nervis 
nervis testaceis. Pedes nigri, pallido-pilosi, tibiis posticis, tarsisque omnibus, rufo-testaceis. Scopula fulvescunt. Scopa argenteopallicla.

Aв Dомen lanceolato-ovatum, nigrum; tergo convexo, nitido, subtilissimè punctulato; segmentis apice obscurè pallidis, duobus intermediis utrinque ciliâ parvâ, marginali, albâ, ultimis tribus pilis brevibus, decumbentibus, nisi a latere et sub lente vix conspicuis, flavescentibus. Ani Fimbria fulvescit. Venter cinereosubhirtus, segmentis fimbriâ brevi, densâ, fla-. vescenti, ciliatis.

sulinca- 98. M. atra, albido-subvillosa; abdomine punctuna. lato; digitis omnibus, plantisque posticis, rufis, MUS. Kirly.

$$
\text { Long. Corp. Lin. } 3 \frac{1}{2} \text {. }
$$

Hab. In Suffolcià, semel lecta.

\section{DESCR. Mas.}

CORPUS atrum, villoso-canescens.

CAPL T trunco latius. Antenne thorace brevi, ores, nigræ.

Tr ncus. Squamula obscuræ, piceæ. Alce subhyalinæ, nervis ferrugineis, costali interiore nigro. Pedes albido-pilosi, digitis omnibus, plantisque posticis, rufis; plantæ item intermediæ intus subrufæ. Tibiarum Spinulce albæ.

Aв DOMEN ovato-lanceolatum, sub lente punctulatissimum, pilis brevissimis, decumbentibus, pallidis, 
pallidis, unde fuscum nudis oculis videtur, irroratum; segmentis margine submembra-, naceis. Anus acuminatus.

It is possible that this may be the male of the preceding species, but it differs too much from it to take this for granted without further proof.

99. M. atra, supra nudiuscula ; tibiis posticis scopâ digitalis. argentea ; digitis ferrugineis.

MUS. Kirby.

Long. Corp. Lin. 5.

Hab. Barhamiæ rarissima.

DESCR. Acul.

CORPUS atrum albido-subvillosum.

$\mathrm{C}_{\mathrm{APUT}}$ villosum satis, occipitis pilis cinerascentibus. Antennce supra nigræ, subtus piceæ, articulis distinctis.

Truncus. Thorax nudiusculus, nitidus, punctatus. Metathorax utrinque albido-villosus. Squamula nigro-piceæ. Alce subhyalinæ, apice, nervisque, nigricantibus. Pedes albidopilosi. Tibice posticæ scopâ argenteo-nitidâ. Scopulce albidæ, dimidiato-nigræ. Digiti ferruginei.

Ав DомеN aterrimum, subovale, segmentis duobus intermediis utrinque ciliâ marginali albâ. Ani Fimbria haud densa, pallida. Venter, anum versus potissimùm, hirtus.

Obs. In adultioribus cilia marginalis segmentorum dorsalium aldominis interdum abrasa. 
The articulations of the antennæ are much more distinct in the present species, than they usually are in this sex. Those hairs of the scopula on the inside of the posterior planta, which are next the tibia, are white; while those of the lower half of it, next the digitus, are black.

Shawella.100. M. atra, glabriuscula; abdomine nitidissimo, subcuneiformi, segmentis intermediis utrinque albo-ciliatis; scopâ versicolori.

MUS. Kirby.

Long. Corp. Lin. 4.

Hal. Barhamix, lecta semel Septembre ineunti 1799.

DEESCR. Acul.

CORPUS atrum, glabriusculum.

Caput pilis pauculis, cinereis respersum. $A n-$ tennce nigræ.

Truncus. Squamula nigro-piceæ. Ala infuscatæ, nervis nigris. Pedes nigri, pallido-pilosi. Tibia posticæ scopâ supra nigrâ, subtus argenteâ, certo situ versicolori. Scopulce fulvescunt. Digiti picei.

AвDomen subcureiforme $(r)$, piceo-nigrum, nitidissimum, lateribus quasi crenatis ; segmentis tribus intermediis utrinque ciliâ brevi, haud densâ, marginali, albâ. Ani Finıbria cineras cit. Venter hirtulus.

In honorem D. G. Shaw, M. D. in Zoologiâ haud ulli secundi, nomen dedi.

(r) Tab. 4.**. c. fig. 15.

101. M, 
101. M. atra, glabriuscula; antennis subtus ful-minutula. vescentibus; abdomine nitido; tibiis posticis scopâ argenteà.

MUS. Marsham, Trimmer, Haworth, Lathbury, Kirly.

Long. Corp. Lin. $2 \frac{1}{2}-3 \frac{1}{2}$.

$\mathrm{Hal}$. Barhamiæ, in floribus et aggeribus nudis frequens, in puteo cylindrico nidificans.

DESCR. Acul.

CORPUS atrum, pilositate parvâ subincanum.

$\mathrm{C}_{\mathrm{APU}}$. Facies utrinque ad oculos villosa. Vertex maculis duabus sericeo-pallidis, sine lente vix conspicuis, notandus. Antenne nigræ, apice subtus fulvo.

Truncus. Squamula piceæ. Alle paulò infuscatæ; nervis ferrugineis, costali interiore nigro. Pedes albido-pilosi. Tibice posticæ scopâ cinerascenti, certo situ argenteo splendore micanti. Digiti rufi. Scopula fulvæ.

AвDomen subovale, atrum, nitidum, segmentis pilis pauculis, albis, infra marginem ciliatis. Ani Fimbria cinerea.

$V a r . \beta$ antennis subtus piceis.

Maris Corpus albido-villosulum. Antenne thorace breviores. Alce subhyalinæ, iricolores, apice obscuriores. Abdomen valde convexum pilis albidis incanum. Plantee posticæ rufæ.

$V_{a r} \beta$ antennis totis nigris.

102. M. atra, albido-villosula; abdomine nitido, nana, segmentis basi punctulatissimis; tibiis posticis scopâ argenteâ. 
MUS. Kirly.

Long. Corp. Lin. $3-3 \frac{1}{2}$.

Hab. Barhamix, bis capta.

DESCR. Acul.

CORPUS atrum, albido-subvillosum.

$\mathrm{C}_{\text {aput. Vertex immaculatus. Antennce nigræ; }}$ capite longiores.

Truncus. Squamule nigræ. Alee hyalinæ, splendidè iricolores, nervis nigris. Pedes albido-pilosi. Tilice posticæ scopà albidâ, certo situ argenteo-micanti. Scopula fulvescunt, Digiti picei.

Авдомen subovale, atrum, glabrum, nitidissimum; segmentis, basi potissimùm, subtilissimè punctulatis, intermediis tribus, ciliâ haud densâ, marginali, albâ, antịcis interruptâ. Ani Fimbria alba. Venter segmentis margine albo-ciliatis.

Maris Antenne nigræ, thoracis ferè longitudine. Facies anticè longiùs et densiùs barbata. Alae apice obscuriores. Aldomen albido-pilosulum.

parvula. 103. M. atra, cinereo-subvillosa; abdomine subrotundo.

MUS. D. Marsham, Latham, Haworth, Lathlury, Trimmer, Sou'erly, $M$ 'Lcay, Kirly.

Long. Corp. Lin. 3.

Hal. Barhamiæ, cum præcedentibus frequens. Detecta Aprile ineunti 1799, in floribus copulans. Mos* cham spirat.

DESCR. 
DESCR. Acul.

CORPUS atrum, cinereo-subvillosum.

CAPUT villosum admodum. Vertex maculd sericeâ utrinque ad oculos, obscurâ tamen, notandus. Antennce nigræ.

Truncus. Squamula piceæ. Alæ paululùm infuscatæ, splendidè iricolores, nervis nigricantibus. Pedes cinereo-pilosi. Tilice posticæ scopâ cinereà.

Ав оомеN breve, latum, pilosulum, maximè latera versus et anum. Venter cinereo-hirtus.

Maris Facies atro-hirsuta. Antenna thorace breviores. Squamule nigræ. Ala coloribus prismaticis splendidissimè micantes. Aldomen subovatum, convexum.

M. minutula, nana, and parvula are very similar to each other, and extremely liable to be confounded ; they are however distinct species, having each a peculiar male. M. minutula is less hairy than either of the others, the underside of its antennæ is more or less red, as are also its digiti. From $M$. nana it is sufficiently distinguished, by having the surface of its abdomen impunctulate, and by its brown wings. The antennæ also of its male are proportionably shorter, then those of the same sex of that insect. Its silver scopa, and differently formed abdomen, evince its distinction from $M$. parvula. The innumerable punctula which, under a common magnifier, are visible upon the abclomen of $M$. nana, furnish a characteristic which well disvol. Ir. 
tinguishes it from the other two. And M.parvula may always be known by its short abdomen, and the cinereous hairs which cover its head and trunk. The hair upon the face of its male is black.

pilosuia. 104. M. nigra, cinereo-subpilosa ; capite atro; abdomine subovali, segmentis margine membranaceis; digitis ferrugineis.

MUS. Kirby.

Long. Corp. Lin. $3 \frac{3}{4}$.

$H a b$. in Angliâ, ubi lecta haud bene memini.

\section{DESCR. Mas.}

CORPUS nigrum, pilositate cinerascenti.

Caput. Facies atro-villosa. Antennce thoracis ferè longitudine, nigræ.

Truncus. Squamula piceæ. Ala subhyalinæ, nervis ferrugineis, costali interiore nigro. Pedes cinereo-hirti, digitis omnibus, plantisque posticis, obscurè ferrugineis. Scopulce flavescunt. AвDOMEN ex lincari ovale, cinereo-pilosulum, segmentis margine rufescente-membranaceis.

This insect is considerably larger than the male of the preceding species, which it somewhat resembles; its abdomen is longer and more oval, and its digiti are ferruginous.

xanthura. 105. M. atra, cinereo-subpubescens; ano, tibiis plantisque posticis, rufescentibus; abdomine fasciis subinterruptis, albiclis.

MUS. D. Marsham, Lathlury, Sowerly, Haworth Mas $\beta$, Kirly. 
Long. Corp. 'Lin. 5-6.

Hab. Barhamiæ, capta etiam a D. Trimmer prope Londinum.

DESCR. Acul.

CORPUS atrum, cinereo-subpubescens.

$\mathrm{C}_{\mathrm{A}} \mathrm{Pu}$ T. Antenna nigræ, apice subtus piceo.

Truncus. Thorax pube brevissimâ, rarâ, conspersus. Metathorax utrinque et posticè villoso-flavescens. Squamulce rufo-piceæ. Alce subtescaceæ apice obscuriores; nervis, costali interiore nigro excepto, ferrugineis. Pedes flavescente-pilosi, tibiis plantisque posticis rufo-testaceis. Scopce subflavæ. Scopulce fulvoaureæ. Digiti picei.

Ав оомеN oblongum, nigrum, obscurum, segmentis tribus intermediis margine albo-ciliatis, anticis duobus interruptè. Ani Finıbria fulvescens. Venter segmentis pilosulis, marginibus longiùs ciliatis.

$V a r . \beta$ antennis totis nigris; metathoracis villis, scopâque albidis.

$\gamma$ abdomine subovato, convexo, alias $\beta$ simil lima. An eadem?

Maris Corpus atrum, cinereo-villosum. Nasus porrectus. Antenna thoracis ferè longitudine. Pedes nigri, toti cinereo-hirti. Scopulce pallidæ. Abdomen ovatum, breve, convexum, atrum, pilosulum; segmentis tribus anticis margine utrinque villoso-albis. Venter anum versus M 2 hirtus, 
hirtus, segmentis margine fimbriâ densâ, brevi, pallidè aurcâ ciliatis.

Far. $\beta$ abdomine angustiori, segmento solummodo secunclo margine utrinque villoso-albo.

convexius 106. M. nigra, griseo-subpubescens; abdomine cula. ovato, convexo, segmentis margine pallidis; tibiis plantisque posticis rufis.

MUS. Kirly.

Long. Corp. Lin. 5.

IIal. Barhamix, semel lecta, iterum prope Norvicum,

DESCR. Acul.

CORPUS nigrum, grisescente- pubescens.

Caput. Facies fulvescente-villosa. Antenna nigrax.

Truncus supra pube haud densâ sordidè fulvâ tectus. Squamule piceæ. Alce subhyalinæ, apice obscuriores; nervis testaceis, costali interiore nigro. Pedes grisesccnte-pilosi. Tibia Plantceque posticæ rufx, illæ ncbula nigricanti. Scopa pallida. Scopula fulvo-aurex. Digiti picei.

AвDOMEx ex conico suboratum, convexum, fusco-nigrum, punctulatissinum punctulis levissimè impressis, pilis decumbentibus, brevissimis, rufescentibus, unde nudis oculis fuscum esse videtur, conspersum, segmentis margine pilis brevibus luteo-pallidis, anticis duobus interruptè, ciliatis. Ani Fimbria densa, lutcopallida. Venter convexus, anum versus hirtus. 
The abdomen of this species is more convex, both above and below, than is usual in the present family; a circunstance which sufficiently distinguishes it from any other.

107. M. nigra, grisescente-subpubescens; thorace fuscata. fusco; abdomine ovato, convexiusculo, segmentis margine pallidis.

MUS. Kirby.

Hob. Barhamiæ, Maio medio 1500 , in floribus lecta.

DESCR. Acul,

CORPUS nigrum, pube grisescenti.

Caput. Facies anticè fulvescente-villosa. Occipitis pili fusci. Antenne subtus picco-nigra.

Truncus. Thorax nitidus, pube, haud densâ fusco-nigricanti. Squamula nigre. Ala hyalinæ, apice paulò ubscuriores; nervis, crassioribus nigris exceptis, anastomosique, ferrugineis. Pedes nigri, pallido pilosi. Titie posticæ scopà fulvâ.

A B Domer ex cordato suboratum, convexiusculum, glabrum; seginentis margine pallido ciliatis, anticis interruptè. Ani Fimlria rufescens.

M. fuscata, at first sight, might be mistaken for M. convexiuscula; but the down of the thorax is of a much darker hue, the posterior tibire and tarsi are black, the scopæ are tawny, and the abdomen is not so convex either above or below. Upon this 
insect I found a Pediculus, nearly related to the $P$. Apis of Fabricius, but I think distinct, which I shall describe in the margin (s). The $P$. Apis is not uncoinmon upon the insects of this genus, I have found fourtcen or fifteen upon the same individual; I have likewise frequently met with it upon genuine Apes. From Reaumur and De Geer we learn, that it also infests some individuals of the genus Musca $(t)$; for it appears evident, that the hexapod, of which the latter author gives a long account as the larva of Meloe Proscarabous, strange as it may seem, is no other than this insect. His description and figure tally with it exactly, not varying from the specimens I have examined in the slightest degree. This illustrious author, upon whose accuracy the greatest reliance may generally be placed, assures us, that from a mass of the eggs of this Meloe these larvæ procceded; that he compared them with some he discovered upon Musca

(s) Mclitta, P. linearis, niger; ore, tibiisque testaceis.

Long. Curp. Lin. $\frac{3}{4}$.

$\mathrm{Hal}$, in Melittis semcl lectus.

Major P. Apum et distinctus, Corpus angustum, lineare, nigrum. Antennce biarticulatæ setâ terminali. Thorax trium segmentorum. Tilia Tarsique pallidè testacei; hi ferè lanceiformcs, exarticulati, utrinque sctâ armati. Anus setis quatuor instructus exterioribus brevibus. Vid. Tab. 14. n. 11. fig. 10, 11, 12 .

(t) Reaum. tom. 4. Mem. 11. p. 490. tab. 31. fig. 17.

De Gcer. tom. 5. p. 8-12. tab. 1. fig. 5-8.

intricaria, 
MELITTA. (**. c.)

intricaria, Lin. and found them exactly the same; that he put a large fly or two amongst them, to which they attached themselves with the greatest avidity. Similar animals are mentioned to be hatched from these eggs both by Frisch and Goedart. Here seems to be an accumulation of evidence in confirmation of this extraordinary fact; and yet, tó use De Geer's words, "Qui se seroit jamais imaginé, qu'on trouveroit les petits ou les larves des Cantharides de cette espece sur le corps des Mouches? Jamais on ne se seroit avisé de les y chercher(u)." Nothing seems more improbable than that a bee or a fly should afford nutriment to the larva of so large an animal as Meloe Proscarabceus, and that it should feed in the same manner as an Acarus or Pediculus. Its dimensions, one would think, if it was only a larva, would be found different in different individuals, according to their age; but this is not the case, for the animal in question varies scarcely at all in size. Can we suppose, that when it has attained to a certain size, it quits this kind of food for some other? All circumstances considered, I cannot help suspecting that there is some illusion in the case, which perhaps future observation will clear up.

108. M. atra, fulvo-villosa; thorace ferrugineo; Afzeliel abdomine subcordato, fasciis tribus, inter- ${ }^{l a}$. ruptis, pallidis.

(u) De Geer. tom. 5. p. 12. 
MUȘ. D. Marsham, Latham, Hau'orth, Lathlury, Trimmer, Souerly, Kirly.

Long. Corp. Lin. $4-4 \frac{y}{2}$.

Hab. Barhamix, in floribus et sylvis tempore vernali haud rara. Recens insectum suavem spargit odorem.

DESCR. Acul.

CORPUS atrum, fulvo-villosum.

$\mathrm{C}_{\text {A }} \mathrm{PU}$ t villoso-grisescens. Vertex calvus. $A n$ tennce nigræ.

Truncus. Thorax nitidus, punctatus, ferrugineo-subpubescens. Metathorax utrinque fimbriâ rufescenti. Squamula piceæ. Alce subhyalinæ, apice obscuriores ; nervis, costali interiore nigricanti excepto, rufis. Pedes pallido-pilosi. Tibice posticæ scopa fulva. Flocculus Scopulceque fulvi.

AвDомEN subcordatum, atrum, punctulatissimum, basi, anoque, fulvo-villosum ; segmentis duobus intermediis utrinque, quarto margine toto, tomentoso-albidis. I'enter convexus, per fascias hirtus.

Var. $\beta$ plantis posticis, digitisque omnibus, rufis. $\gamma$ minor, corpore griseo-subvilloso, abdomine segmentis duobus anticis margine utrinque, proximis duobus margine toto, anoque, tomentoso-pallidis.

Obs. Hujus varietatis aldomen ad figuram rotundam proximè accedit. An eaden?

$\delta$ corporis pube, imò etiam thoracis, cinerascenti ; 
MELITTA. (**. c.)

rascenti; antennis apice subtus piceo; tarsis ferrugineis. An eadem ?

In honorem D. Adam Afzelii, M. D. Sueci, Botan. Demonstr. Upsal. viri celeberrimi et meâ tenui laude majoris, hoc insectum nominavi.

I suspect that varieties $\gamma$ and $\delta$ of this species may be distinct, they agree, however, with $\alpha$ and $\beta$ in so many respects, that I have not ventured to separate them.

109. M. nigra, cinereo-subpubescens; thorace fla-tricincta. vescenti; abdomine ovato, basi subretuso, fasciis tribus, angustis, pallidis.

MUS. Kirly.

Long. Corp. Lin. 5.

Hab. in Angliâ, semel lecta.

DESCR. Acul.

CORPUS nigrum, cinereo-subpubescens.

$\mathrm{C}_{\mathrm{APUT}}$ albicante-villosum. Lingue apex longior quàm in præcedentibus. Auriculce minutæ. Palpi interiores vix fracti. Valvule apice cultriformi. Antenna apice subtus rufopiceo. Stemmata in lineâ curvâ.

Truncus. Thorax pube flavescenti tectus. Squamula piceæ. Alce hyalinæ, apice obscuriores, nervis nigricantibus. Pedes nigri, pallido-pilosi. Tibice posticæ scopâ certo situ argenteâ. Scopulce fulvescunt. Digiti posteriores infra apicem plantæ inserti. Flocculus obsoletus. 
MELITTA. (**. c.)

A B Domen ovatum, basi villosum et subretusum, segmentis tribus intermediis margine tomentoso-pallidis. Ani Fimlria medio atra, utrinque pallida. Venter, anum versus potissimum, cinereo-hirtus.

This and the following species vary from the characters of the insects of this genus, and approach to those of genuine Apes. Their tongue is longer with very minute auricles, and the tops of the valvulæ are cultrifrom $(x)$. They still, however, retain so much of the character of Melitta, as to be properly placed in that genus, and they will rank very well with the insects that compose the present family, with which they agree in habit. If considered as forming a distinct subdivision, it may be regarded as a connecting link between the genera which partakes of the characters of both.

chrysura.110. M. atra, grisescente-subpubescens; thoracis limbo fulvescenti; abdomine ovato, basi retuso, ano fulvo-aureo.

FIG. Andrena homorrhoidalis. Panzer. Fn. Ins. Germ. Init. n. 65. tab. 20.

MUS. D. Marsham, Trimmer, Haworth, Sowerly, Kirly. Long. Corp. Lin. 6.

Hab. Barhamiæ, in floribus Campunula rotundifolia et Trachelii femina haud rara. Mas circa aggeres apricos tempore vernali obvius, feminæ etiam sæpe comes.

DESCR. Acul.

CORPUS atrum, pube griseâ.

(r) Tab. 3.**. c. fig. 8,9 .

CAPUT 
CAPUT admodum villosum. Oris barba fulvoaurea. Occipitis pili atri. Labium tuberculo nullo. Antennce apice subtus piceo.

Truncus. Thorax anticè et utrinque pube fulvescenti, disco atro rariùs piloso. Squamule piceæ. Ala subhyalinæ, apice obscuriores, nervis nigris. Pedes fulvo-pilosi. Tibice posticæ scopâ fulvo-aureâ. Scopula ferrugineæ. Digiti obscurè rufi, postici infra apicem plantæ inserti. Flocculus obsoletus.

АвDomen ex oblongo ovatum, basi retusum, segmento primo villoso-grisescenti, tribus promixis ciliâ brevi, marginali, albâ. Ani Fimbria fulvo-aurea. Venter subhirtus, ano pube densâ, fulvâ tecto.

Obs. In adultioribus corporis pubes cinerascit, et cilia marginalis segmentorum abdominis dorsalium haud rarò abraditur.

Maris Antennce thorace breviores, apice subtus dentato $(y)$. Facies villis densis, albicantibus valde hirsuta. Occipitis, itemque Thoracis pubes, densa, subflava. Abdomen subhirsutum.

$V$ ar. $\beta$ cinereo-villosus, thoracis disco atro, piloșo.

The insect now described appears evidently to be the Andrena hamorrhoidalis of Panzer, but I think not of Fabricius. His description, however, is so very short, that I do not feel quite assured that it belongs to the insect I have given for it above, ra-

(y) Tab.4. **, c. fig. 17. 
MELITTA. (**. c.)

ther than this. This Melitta is not uncommon in the flowers of Campanula rotundifolia and Trachelium, but it seldom, with us, frequents any other plant. The male, not unfrequently, attends the other sex in her flights.

Swam- 111. M. atra, pallido-villosa; abdomine fasciis trimerdam- bus albidis; pedibus posticis fulvo longis-
ella. simè lanatis.

\section{$\triangle \mathrm{CUL}$.}

FIG. Swammerdam. Bil. Nat. tal.26. fig.7.

Schaff: Icon. tab. 32. fig. 5.

Andrena plumipes flavo hirsuta ; abdomine nigro fasciis tribus albis interruptis; pedibus posticis flavo hirsutissimis.

Panzer. Fn. Ins, Germ. Init. n. 46. tal. 16.

$$
\text { , MAS. }
$$

Apis farfarisequa. Panzer. Fn. Ins. Germ. Init. n. 55. tab. 14.

MUS. D. Marsham, Smith, Latham, Lathbury, Haworth, Trimmer, $M^{\mathrm{c}}$ Leay, Kirly.

\section{Long. Corp. Lin. 7.}

Hal. Barhamiæ, declivia graminosa frequentans, et ibi puteos cylindricos sibi fodiens, ubi nidificat, et in quibus femina diebus apricis circa horam meridianam tempore autumnali insidet, capite versus orifiçum putei, dum mas eam circumvolitat difficillimus prehendi. In floribus etiam Jacoliace uterque sexus haud infrequens.

DESCR. Acul.

CORPUS atrum, pallido-villosum.

САрчт. Lingure apex elongatus, attenuatus.

Vertex atro-pilosus. Antenna nigræ.

Truncus 
Truncus supra fulvo-pubescens, thoracis disco pilis sparsis, atris consperso. Squamula nigræ. Alce hyalinæ, apice nigricantes, nervis piceis. Femora pallido-barbata. Tibice rufopilosi. Plante extra pilis atris hirtæ, intus scopulis fulvis. Tibice Plantaque posticæ lanâ densâ, longissimâ, fulvâ, undique barbatæ(z). Digiti articulo extimo rufo.

Авдомеn subovale, atro-pubescens, segmento primo villoso-pallido, proximis tribus margine tomentoso-niveis, anticis interruptè. Ani Fimbria densa, nigricans. Venter per fascias nigricante-pubescens.

Maris Corpus supra pube densâ pallidè rufescenti; subtus albescenti, tectum. Antennce vix thorace breviores, nigræ. Pedes hirti, postici elongati, plantis longiùs, sed haud densè, villosis. Abdomen ex lanceolato-ovatum, per fascias rufescente-hirsutum, segmentis margine albidioribus.

This elegant insect has been long known, for it was in the collection of the celebrated Swammerdam, one of the fathers of Entomology, and has been tolerably figured by him. I have therefore decorated it with his name. Panzer has an admirable figure of it, under the name of Andrena plu-mipes, but in his description of it he says, "Caput

(z) Tab. 4.**. c. frg. 14 . 
nigro hirsutum — pedes flavo hirsuti_ale hyaline, flavescentes." These circumstances do not agree with our specimens, which renders his synonym rather doubtful. He has figured the male as the Apis farfarisequa of Scopoli, in this I think he is mistaken.

No person at first sight would take the male and female of $M$. Swammerdamella for the same species, so widely do they differ in most particulars; nor should I have suspected that there was any connexion between them, had I not discovered their retreats. In the month of August, 1797, I saw a female take her flight from a grassy declivity of a southern aspect, which was much entangled with roots and shrubs. Upon examining this spot more narrowly, I discovered a number of small burrows, each of which had a little heap of sand, which had been excavated from it, lying before it. In some of these burrows I saw our Melitta sitting, with her head at the mouth, enjoying the sunshine; at the same time I observed many other insects flying about the spot. Upon my attempting to take them they disappeared, but they soon returned to their amusement. With some difficulty, I at length succeeded in taking one, and it proved to be the male just described. I have since frequently visited the same spot, and at the proper season have always found these insects there, both males and females, employed in the manner I have mentioned.

These 


$$
\text { MELitTA. (**. c.) }
$$

These circumstances convince me, that, though they differ so much in form and hirsuties, they are only the two sexes of the same species; especially since they agree in the shape of the tongue, which approaches very near to that of a genuine Apis, 


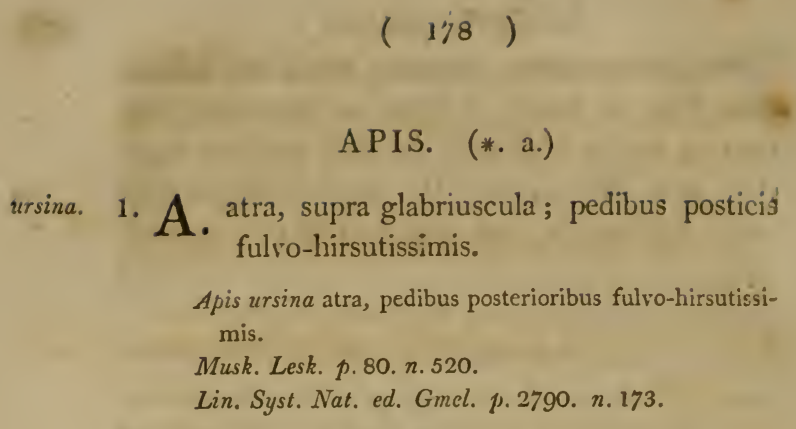

FIG. Tal. 16. fig. 1 Var. $\beta$.

MUS. $\alpha$ D. Drury Apis, n. 71 . $\beta$ Kirly.

Long. Corp. Lin. $3 \frac{1}{2}-5$.

Hal. In Suffolciâ, a nobis semel lecta, Septembre ineunti 1797 , in ericeto dicto Martlesham heath, prope Woodbridge.

DESCR. Acul.

CORPUS atrum, pube, rarâ admodum, nigricanti.

CAPU T subrotundatum, nigro hirsutulum. Latii apex subreflexus. Maxilla forcipatæ, apice piceæ. Antennce capite breviores, piceo-nigræ. Truncus. Squamula castaneæ. Alce infuscatæ ; nervis, excepto costali interiore nigro puncto pallido, ferrugineis. Pedes rufo-pilosi, femorum barbâ nigrâ. Tilice Plantaque posticæ fulvo longissimè lanatx. Digiti ferruginei.

АвдомеN ovale, supra pilosulum, segmentis margine membranaceis. Ani Fimbria nigricans. Venter convexus, per fascias nigricantepubescens.

Var. 
A P IS. (*. a.)

Var. $\beta$ triplo minor, alis subhyalinis. An eadem?

This insect appears evidently to be the Apis ursina of the Museum Leskeanum. It is extremely rare, as indeed are all the species of the present family. I have not seen a single exotic specimen belonging to it.

2. A. atra, nitida, glabriuscula; antennis dimidiato-Linnaelrufis.

FIG. Tal. 16. fig. 2.

MU. D. Marsham, Kirly.

Long. Corp. Lin. $3 \frac{\frac{1}{2}}{2}$.

Hab. In Suffolciâ,, semel a nobis cum præcedente capta, semel etiam a D. Goodenough.

DESCR. Mas:

CORPUS atrum, nitidiśsimum, parum pubescens. Caput. Maxilla forcipatæ. Oculi parvi. Antenne rufæ; basi nigræ.

Truncus. Squamula piceæ. Ala hyalinæ, nervis ferrugineis. Pedes piceo-nigri, cineras= cente-pilosuli. Tibice posticæ clavatæ, subdolabriformes (d). Scopulce fülvæ:

Ádomen ovatum, segmentis margine depressiusculis et submembranaceis.Venter nigropiceus.

3. A. atra, nitida, glabriuscula; digitis rufis。

MUS. D. Banks, Marsham, Drury Sphex, n. 15. Latham, ana. Kirby.

Long. Corp. Lin. 5.

Hab. Prope Londinum. A me nunquam lecta.

(a) Tab. 4. Ápis. *. a. fig. 14.

vol. Ir. 
DESCR. Mas.

CORPUS atrum, lucidum, parum pubescens.

Capu subhirsutum. Antenne subtus picex. Oculi parvi.

Truncus. Squamule piceæ. Ale paululum infuscatæ; nervis, excepto costali interiore anastomosique nigris, ferrugineis. Pedes rufescente-villosuli, digitis ferrugineis.

AвдомеN ovatum, segmentis margine depressiusculis. Venter villosulus.

This insect is extremely similar to the preceding species; but, although of the same sex, it is as large again. Its antennæ are black, and its digiti ferruginous.

*. b.

Goodeni- 4. A. atra; tuberculis, squamulis, scutellique puncana. tis, flavis; abdomine fasciis flavis, nigrisque, alternis.

MUS. D. Marsham, Latham, $M^{\complement}$ Leay, Haworth, Lathlury, Sowerby, Francillon.

Long. Corp. Lin. $5 \frac{1}{4}-6$.

Hab. Barhamiæe et alibi, in aggeribus viarum apricis mense Maio frequens, odore Melissa flagrantissima. Mas in floribus Grossularia.

DESCR. Acul.

CORPUS atrum, pube grisescenti.

Cдрuт. Maxille rufæ, apice fuscæ. Antenna, Labium, Nasus apice, rufi. Facies utrinque ad oculos flava.

Truncus. Collare, Tubercula, Squamula, Metathuracis 
tathoracis maculæ duæ, Scutelli puncta totidem lineolaque transversa, flava omnia. Alce testaceæ, apice nigricantes lunulâ albâ. Pedes ferruginei, femoribus basi subtus, apophysibusque nigris.

AвDOMEN ovatum, atrum, fasciis quinque flavis, quarum antica subintegra, intermediæ duæ medio attenuatæ. Venter niger, fasciis quatuor subrepandis, flavis.

Var. $\beta$ labio fusco; abdominis fasciâ anticâ interruptâ.

$\gamma$ scutello lineolà transversâ nullâ, alias $\beta$ similis.

$\delta$ metathorace immaculato, alias $\alpha$ similis. $\varepsilon$ metathorace immaculato; abdominis fascià anticâ interruptâ; ventre fasciis binis intermediis, strigâ anticâ, punctisque duos bus posticis, flavis.

Maris Corpus albido satis villosum. Caput anticê flavum, flavedine oculos semiambiente, versus antennas trifurcâ, dente intermedio breviori. Antennce scapo nigro, subtus flavo, apice articulis quinque primis supra maculâ nigricanti. Scutellum punctis duobus flavis. Metathorax immaculatus. Pleurce anticè lunulà flavâ pictæ. Pedes rufo, nigro, flavoque variegati. Apos physes quatuor anteriores flavo maculatæ. Abdomen nigrum, supra et infra fasciis quinque, anoque, flavis; segmentum ultimum dorsale emarginatum, $\int$. bidentatum. 
$V$ ar. $\beta$ capitis flavedine versus antennas bifurcâ ; abdominis tergi fascia anticâ interruptâ. $\boldsymbol{\gamma}$ capitis flavedine versus antennas bifurcâ ; abdominis tergi et ventris fasciâ anticâ interruptâ.

Obs. Infinitâ ferè varietate gaudet hac species in utroque sexu. Precipuce supra dantur, alice minùs insignes.

$A$ viro Reverendo S. Goodenough, LL. D. Canonico Windsoriensi, Botanico summo tum et in Entomologiâ lynceo, nomen suum hac Apis nutuatur.

A. Goodeniana resembles a good deal Nomada succincta, figured by Panzer $(l)$; but I think it very distinct. It differs in the colour of the lip, of the anterior part of the face, the antennæ, and especially of the legs, which in his are described as entirely yellow with black thighs, and a black spot on the posterior tibiæ; these, in our males, for his figure represents a male, are red, variegated with yellow only on the anterior side, with red primary and secondary thighs, marked with a black line underneath ; the third pair being black on the posterior side, and red only before and at their tips.

allernata.5. A. atra, giseo-subvillosa; tuberculis, squamulisque flavescentibus; abdomine fasciis flavis, nigrisque, alternis; scutello immaculato.

MIUS. D. Marsham, Kirly.

Long. Corp. Lin. $5 \frac{1}{2}$.

(b) Fn. Ins. Germ. Init. n. 55. tab. 21.

Hal. 
Hab. Barhamiæ. Tempore vernali in floribus Grossularice bis capta.

DESCR. Mas.

CORPUS atrum, pube grisescenti.

$\mathrm{C}_{\mathrm{APUT}} \mathrm{P}$ anticè flavum flavedine versus antehnas bifurcâ. Maxillı apice fuscæ. Antennce rufæ, supra basi nigræ, scapo antrorsum lineolâ rufâ. Truncus. Collare utrinque, Tubercula, Squamulce item extrorsum, sulphurex. Scutellum immaculatum. Pleurce antrorsum maculâ parvâ, sublunatâ, flava. Alce subtestaceæ, apice fuscescentes. Pedes rufi, femoribus subtus nigris, primariis antrorsum fulvescentibus. Apophyses nigræ.

ABDOMEN atrum, supra et infra viridi-flavo fasciatum fasciâ anticâ interruptâ. Anus apice bidentatus.

This species possesses most of the characters which distinguish the same sex of the preceding, and I should have assigned it only a station amongst the varieties of this sex of that insect, had it not wanted those characters which seem constantly to attend them: namely, the two yellow dots upon the scutellum, the yellow markings of the legs, and the yellow spots which are observable on the four first pair of apophyses; not to mention slighter differences.

6. A. atra, cinerascente-subvillosa; scutelli punctis $L a t h l u-$ duobus, abdominisque fasciis posticis, flavis; anticâ rufâ. 
MUS. D. Marsham, Kirly.

Long. Corp. Lin. $4 \frac{3}{4}$.

Hab. Prope Woodbridge in Suffolciâ, a D. Lathbury semel capta, semel etiam a D. Marsham.

DESCR. Mas.

CORPUS atrum, cinerascente-villosum.

CAPUT anticè flavum, flavedine oculos semiam. biente, versus antennas trifurca dentibus subæqualibus. Maxilla apice fuscæ. Antennce rufæ, basi supra piceæ, scapo antrorsum flavo.

Truncus. Tubercula, Scutellum punctis duobus, Pectus anticè utrinque maculâ lunatâ, flava. Squamula extrorsum fulvæ. Alce testaceæ. Pedes antici flavi, posteriores quatuor rufi geniculis sulphureis. Femora postica nigra, antrorșum ferruginea. Apophyses nigræ, anticis antrorsum macula flava, apex rufescens.

A BDOMEN ovato-lanceolatum, segmento primo basi nigro, apice latè rufo, proximis tribus flavis, margine rufo-piceis. Anus flavus, segmento ultimo integro, rufescenti. Venter fasciis nigris, flavis, rufisque variegatus.

$\operatorname{Var} . \beta$ oculorum ambitu ferè toto, collare utrinque, squamulisque flavis.

Pueritice comiti ferè ab incunabulis, adolescentice mece et maturiorum annorum amico jucundo, entomologo prastanti, et rerumb naturalium observatori, item pictori, accuratissimo, Viro Reverendo Petro Lathbury, Woodbridgensi, hoc insectum sacrun esse volui. 
7. A. atra; scutello, tarsis, tibiis extra, abdominis-varia. que fasciis posticis, flavis, anticâ rufâ.

FIG. Nomada varia antennis pedibusque ferrugineis, abdomine flavo, anticè rufo, fasciis tribus nigris.

Panzer. Fn. Ins. Germ. Init, n. 55. tab. 20.

MUS. Kirly.

Long. Corp. Lin. $4 \frac{1}{2}$.

Hal. Barhamiæ, semel capta Septembre ineunti 1799, semel etiam a D. Lathbury.

DESCR. Mas.

CORPUS atrum, pube cinerascenti.

CAPUT, et oculorum ambitus anticè, flavi, flavedine versus antennas trifurcâ. Maxilla apice fuscæ. Oculi, in vivo, chrystallino-virentes. Antenna rufæ, supra liturâ mediâ nigrâ, scapo nigro antrorsum flavo.

Truncus. Collare, Tubercula, Squamulce, Scutellum maculâ subquadratâ, Pleurce lunulâ anticâ, sulphureæ. Alce testaceæ, paululùm fuscescentes. Pedes rufi, tarsis, et tibiis extra, sulphureis. Femora ferruginea, subtus basi nigra. Apophyses nigræ, intermediis articulo secundo lineolâ flavâ inscripto, primariis articulo extimo antrorsum sulphureo.

Ав Domen subovatum, basi nigrum, fasciâ ferrugineâ, dein fasciis, flavis, nigrisque alternis variegatum, segmento ultimo bidentato. $V_{e n}$ ter flavus, nigro fasciatus.

$V$ ar. $\beta$ collare, apophysibusque totis, nigris.

Panzer's Nomada varia is evidently synonymous with the insect here described; though, in his deN 4 scription, 
scription, the legs are denominated ferruginous: the figure, however, represents them variegated with yellow.

fava. 8. A. atra, subvillosą; squamulis fulvis; abdomine fasciis flavis, ferrugineisque, alternis.

FIG. Nomava flava thorace atro, immaculato, abdomine flavo, fasciis quinque rufis, pedibus ferrugineis.

Panzer. Fn. Ins. Germ. Init. n. 53. tab. 21.

MUS. D, Marsham, Drury Sphex, n. 66. Trimmer, Kirly.

Long. Corp. Lin. $3 \frac{1}{2}-4 \frac{1}{2}$.

Hab. Barhamiæ et alibi, haud frequens.

DESCR. Mas.

CORPUS atrum, cinereo-subvillosum.

CAPU T anticè sulphureum. Maxille apice fus cæ. Nasus pube decumbenti, argenteo-pallidâ, barbatus. Antenna ferrugineæ, supra basi dimidiato- nigræ, scapo antrorsum pallidè luteo.

TR"NCus. Tubercula, sic et Squamula, ferrugineæ. Scutellum immaculatum. Ala subhyalinæ, apice nigræ lunulâ albâ; nervis, excepto costali interiore fusco, testaceis. Pedes ferruginei, primarii antrorsum flavi femoribus ultimis posticè, reliquis subtus, nigris.

АвдомеN subovatum, segmento primo atro fasciâ ferrugined, reliquis flavis margine ferrugineis, ultimo bidentato. Venter rufus, fasciis nigris, sulphureisque abbreviatis, variegatus.

$V a r . \beta$ minor, corpore albido-villosulo; antennis supra lineâ nigrâ, per totam longitudinem ductâ, notandis, scapo antrorsum lineolâ rufescent; 
APIS. (*. b.)

rufescenti inscripto; tuberculis atris; $a b$ dominis fascià ferrugineâ anticâ utrinque punctulo nigro notatâ; pedibus primariis flavedine nullâ; tibiis omnibus posticè nebulâ nigricanti.

$\gamma$ antennis supra, scapo toto, tuberculis, femoribus, tibiisque posticis extrorsum, nigris; abdomine segmento antico fasciâ angustâ, repandâ, ferrugineâ, utrinque punctulo nigro notatâ; fasciis flavis duabus intermediis subinterruptis; ventre nigricanti, fasciis tribus, punctoque, flavis.

$\delta$ abdomine lineari-lanceolato, segmentis intermediis fasciâ flavâ, interruptâ. Aliàs $\beta$ similis.

This varying species may always be distinguished by the silver pile that is, as it were, combed over its nasus, by its yellow mouth and ferruginous abdomen variegated above and below with yellow bands. Variety $\delta$ may possibly be a distinct species. Panzer's figure is a very accurate representation of our insect.

9. A. atra; scutelli punctis fulvescentibus; abdo-rufivenminis ventre ferrugineo, tergo rufo, nigro, ${ }^{\text {tris. }}$ flavoque fasciato.

MUS. D. Marsham, Kirly.

Long. Corp. Lin. $4 \frac{1}{2}$.

Hab. In Suffolcia, a me bis lecta, semel etiam a D.

Marsham.

DESCR. 
DESCR. Acul.

CORPUS atrum, rufo-subvillosum.

CAPUT anticè, et oculorum ambitus, ferruginei. Maxillce apice fuscæ. Antennce ferrugineæ, scapo supra nigro.

Truncus. Collare, Squamula, item Pleura macula antica, ferrugineæ. Tubercula, Scutellique puncta bina, fulvo-flava. Alce testaceæ, apice obscuriores lunulâ albâ. Pedes ferruginei, femoribus posticis hinc nigris. Apophyses articulis apice rufis.

АвдомеN subovatum, rufum, fasciis nigricantibus flavisque variegatum. Venter ferrugin neus, immaculatus.

This may probably be the other sex of one of the preceding species, for a ferruginous or red mouth is, in the present family, generally a characteristic of the aculeates, as a yellow one is of the males; but as the sexes usually agree as well in the ventral as in the dorsal markings of the abdomen, and in this respect $A$. rufiventris differs from them, I thought it best to consider it as distinct.

Marsham-10. A. atra; antennis, squamulisque ferrugineis; ella. scutelli punctis, abdominisque fasciis, flavis, anticis tribus interruptis.

MUS. D. Marsham, McLeay, Sowerly, Trimmer, Francillon Kirly.

Long. Corp. Lin. $5 \frac{1}{2}-6$, 
APIS. (*. b.)

Hab. Barhamiæ. In floribus Ranunculi bulbosi lecta exeunte Maio. Prope Londinum sæpiùs a D. Marsham et J. Trimmer capta.

DESCR. Acul.

CORPUS atrum, pube parvâ cinerascenti.

CApUt. Maxille, Labium, Nasus apice, Antenne, ferruginei omnes.

Truncus. Collare, Tubercula, Scutellum punctis duobus, flava. Squamula ferruginex. Alae testaceæ, apice obscuriores lunulâ albâ. Pedes ferruginei, apophysibus, femoribus posticis, et anticis quatuor basi subtus, nigris.

АвромеN lanceolato-ovatum, nigrum, fasciis quatuor, anticis tribus interruptis, anoque, flavis. Venter convexus, niger, segmento secundo utrinque maculâ obliquâ, proximis duobus fasciâ, quinto utrinque punctis duobus, flavis.

Obs. Abdominis fascia antica interrupta e maculis duabus repandis, extrorsum attenuatis, constat.

Var. $\beta$ abdominis tergi segmento primo, et ventris ultimo, punctis tantummodo duobus flavis.

$\gamma$ tuberculis, scutellique punctis rufis; $a b-$ domine segmento primo punctis duobus flavis, tertii fasciâ subinterruptâ; ventre, basi apiceque immaculato.

$\delta$ abdomine segmento primo immaculato; ventre segmento secundo utrinque punc- 
tulis duobus contiguis, tertio fascià inter ruptâ, quarto fasciâ, luteo-flavis, ultimo immaculato. Alias a similis.

Obs. In hấc varielate aldominis segmentum primum punctorum flavorum vestigia, obscurissima tamen et evanescentia, exhibet. Punctula ventralia interdum desunt.

Thomæ Marsham Armigeri nomine, Erarii Societatis Linnæanæ Præfecti; insularum harum nostrarum Entomologia illustrationem pridem feliciter aggressi, et Coleoptera Britannica jam jam publici juris facturi; mihi, in itinerilus Naturce investigationem propter susceptis, scepe comitis jucundi, et semper amici benevoli, hoc insectum condecoravi.

cornigera.11. A. atra; labio subcornuto; abdominis ventre basi ferrugineo, tergo maculis, fasciisque $\mathrm{fla-}$ vis, variegato.

MUS. D. Marsham, Drury Sphex, n. 16. Trimmer, Kirly.

Long. Corp. Lin. $5-5 \frac{1}{2}$.

$\mathrm{Hab}$. Barhamix, aggeribus arenosis, apricis frequens; recens insectum moscham redolet.

DESCR. Acul.

CORPUS atrum, glabriusculum.

$\mathrm{C}_{\mathrm{APUT}}$ anticè rufum, rubore versus antennas trifurco, dente intermedio breviore. Maxillce apice fuscæ. Labium cornu brevi acuto ar- 
APIS. (*. b.)

matum $(c)$. Oculi, in vivo, chrystallino-brunnei. Antenna rufæ.

Truncus. Collare, Tubercula, Squamula, Scutellum punctis duobus contiguis, Metathorax maculis totidem distantibus ferè parallelogrammicis, flava hæc omnia. Pleurce maculà anticâ, obscurâ, ferrugineâ. Alce paululùm infuscatæ, apice obscuriores; nervis, costali interiore fusco excepto, testaceis. Pedes ferruginei, femoribus ternariis posticè et subtus, reliquis basi subtus, nigris. Tibice ultimi paris basi annulo flavo. Apophyses rufæ, articulo primo basi nigro.

AвDомEN ovatum, nigrum, segmento primo fasciâ mediâ rufâ fasciam aliam subrepandam, flavam, medio interruptam includente, intermedis duobus utrinque maculâ introrsum acutâ, ultimis fasciâ, flavis. Venter anticè rufus, fasciis posticis flavescentibus tribus.

Var. $\beta$ pleuræ maculâ flavâ ferrugineo margínatâ; puncto sub alis obscurè ferrugineo pleuræ notantur.

$\gamma$ metathorace immaculato; abdominis segmenti primi fasciâ ferrugineâ strigas tantùm duas flavas includente; ventre fasciis flavis solummodo duaubs. Alias a referens. $\delta$ metathorace immaculato; labii cornu longiori; pleuræ maculâ ut in $\beta$; tibiis posticis

(c) Tab. 5. *. b. fig. 18. $b$. 
liturâ flavâ; ventre basi punctis insupế tribus flavis in triangulum dispositis. $\varepsilon$ faciei rubore tantùm bifurco; metathorace, tibiisque posticis, immaculatis. $\zeta$ præcedenti similis, ventre ferrugineo, fasciis duabus, obscuris, flavis.

The following characters are constant through all the varieties of this Proteus species, namely the short horn upon the lip, which is easily seen under a common magnifier, if the head be viewed from one side, its ferruginous mouth and antennæ, its yellow collar, tubercles, squamulæ, and contiguous spots on the scutellum; and the ferruginous fascia of the first dorsal segment of the abdomen, which includes, and as it were insulates, two irregular yellow spots. When this insect is first taken it emits a very agreeable scent.

sulcornu-12. A. atra; labio subcornuto; abdominis ventre, ta. maculisque tergi anticis, ferrugineis, posticis sex, anoque, flavis.

MUS. Kirby.

Long. Corp. Lin. $4-4 \frac{\pi}{2}$.

Hab. Barhamiæ, lecta in horto Maio exeunti 1800, in floribus Geranii reflexi.

DESCR. Acul.

CORPUS atrum, albido-subpilosum.

CAPU T anticè ferrugineum. Labium tuberculo, f. corniculo brevissimo, nisi a latere et sub lente, 
lente, vix conspicuo, instructum. Oculi, in vivo, pallidè rufescentes. Antennce rufæ.

Truncus. Collare, Tubercula, Scutellum punctis duobus, flava. Alce subhyalinæ, apice nigræ lunulâ albà, nervis testaceis. Pedes rufi, femoribus ultimi paris subtus et posticè, reliquis basi subtus, nigris. Apophyses nigræ, articulis apice rufis.

Ав DомеN subovatum, nigrum, segmento primo maculis duabus repandis rufis, proximis tribus utrinque maculâ introrsum acutâ, anoque flavis. Venter ferrugineus, segmentis margine piceis.

The horn upon the lip of this species is nearly obsolete, and not easy to be discovered. The insect itself is smaller than $A$. cornigera ; its squamulæ are ferruginous, and it wants the yellow spots which are inclosed in the red fascia of the first dorsal segment of the abdomen of that Apis. Its venter likewise has no yellow fasciæ.

13. A. atra; labio subcornuto; abdomine maculis Catrea. anticis ferrugineis, intermediis quatuor, fasciâ, anoque, flavis.

MUS. Kirby.

Long. Corp. Lin. $3 \frac{1}{2}$.

Hab. Barhamix, capta semel Maio ineunti 1799 , in Salicis Caprece amentis.

DESCR. Acul.

CORPUS atrum, griseo-subvillosum.

Caput. 
Capur. Maxilla ferrugineæ, apice fúscæ. Latium ferrugineum, corniculo obsoleto, nisi a latere et sub lente inconspicuo, instructum. Oculi, in vivo, chrystallino-fusci. Antennce rufæ, scapo supra nigro.

Truncus. Tubercula vertice fulvo-flava. Squamulce rufæ. Scutellum immaculatum. Ale hyalinæ, apice nigræ lunulâ albâ, nervis fuscis, anastomosi testaceâ. Pedes ferruginei, femoribus posticis, quatuor anticorum basi subtus, apophysibusque, nigris; hæ articulis apice rufis.

Ав DомеN subovatum, nigrum, segmento primo maculis duabus, parvis, ferrugineis, proximis duobus utrinque maculâ introrsum acutâ, ultimis fasciâ continuâ, viridi-flavis. Venter piceus.

lineola. 14. A. atra; abdomine fasciâ anticâ ferrugineâ; maculis quatuor intermediis, fasciâ, anoque, flavis.

FIG. Nomada lineola antennis, pedibus, abdominisque segmenti primi lineolâ, rufis ; abdomine maculis utrinque fasciisque duabus flavis.

Panzer. Fn. Ins. Germ. Init. n. 53. tal. 23.

MU. D. Marsham, Trimmer, Kirly.

Long. Corp. Lin. $5 \frac{1}{2}$.

Hal. Barhamiæ, capta sæpius tempore autumnali in floribus Umbeilatarum.

DESCR. Acul.

CORPUS atrum, pube parvâ cinerascenti.

CAPUT 
A PIS. (*. b.)

CAPU T anticè ferrugineum. Maxilla apice fuscæ. Antennce ferrugineæ.

Truncus. Collare, Tubercula, Squamule, Scutellum, et Metathorax punctis binis, flava, Pleurce anticè maculà ferrugineâ. Alce pautlulùm infuscatæ, apice nigræ lunulâ albâ. Pedes rufi, femoribus posticis nigris antrorsum ferrugineis. Apophyses apice, intermediæ totæ, rufæ.

Ав домеN subovatum, nigrum segmento primo fascià interruptâ, ferrugineà, proximis duobus utrinque maculâ introrsum acutâ, quarto fasciâ subinterruptâ, quinto toto, sulphureis. Venter ferrugineus segmentorum marginibus nigris.

Var. $\beta$ metathorace immaculato; pleuris maculâ valde obscurâ.

This insect, although of the same sex with the preceding, is more than twice as big; it has not the rudiment of the horn upon its lip, its collar, squamulæ, and two spots of the scutellum are yellow, the anterior margin also of the face is ferruginous; in other respects it a good deal resembles A. Caprece. Panzer's Nomada lineola is evidently nothing more than a variety of it.

15. A. atra; scutello sulphureo; abdomine flavo, fucata basi ferrugineo, fasciis quatuor nigris.

FIG. Nomada fucata antennis, pedibus, abdominisque basí VOL. II.

o ferrugineis, 
ferrugineis, abdomine flavo fasciis quatuor nigris.

Panxer. Fn. Ins, Germ. Init. n. 55. tal. 19.

MUS. D. Trimmer, Kirby.

Long. Corp. Lin. $4 \frac{3}{4}$.

Hab. Barhamiæ rarior. Etiam a D. Trimmer lecta.

DESCR. Acul.

CORPUS atrum, glabriusculum.

$\mathrm{C}_{\mathrm{APU}} \mathrm{T}$, et oculorum ambitus, anticè rufa, rubore versus antennas trifurco. Lalium fulvum. Maxille apice fuscæ. Antenna sensim paulo crassiores, rufæ.

Truncus. Collare utrinque, Tubercula, Squamula, Scutellum totum, sulphurea. Ala testaceæ, apice obscuriores. Pedes rufi, apophysibus, femorumque quatuor posticorum basi subtus, atris.

АвдомеN subovatum, segmento antico ferrugineo, punctis duobus, apiceque, nigris, secundo utrinque flavo, medio ferrugineo, margine nigro, proximis duobus nigris fasciâ, anterioris interruptâ, anoque flavis. Venter segmentis anticis ferrugineis apice nigris, extimis flavescentibus.

Obs. Interdum collare omnino nigrum est.

This insect is well figured by Panzer; but his specimens appear to have had no black dots upon the first dorsal segment of the abdomen, and he describes the underside as black with obscure yellow bands. 
16. A. atra, cinereo-villosula ; abdomine piceo ma- leucophculis septem sulphureis; antennis supra nigris. thalma. MUS. Kirby.

Long. Corp. Lin. 4.

Hal. Barhamiæ, semel in Salicis Caprece amentis lecta،

DESCR. Mas.

CORPUS atruin, albido-villosulum.

CAptr. Maxilla basi sulphureæ, dein ferrugineæ, apice fuscæ. Labium, Frons angulis, et Nasus apice, flava. Oculi, in vivo, chrystallinoalbi. Facies anticè villis decumbentibus, argenteis, barbata. Antenne rufæ, supra, scapoque toto, nigræ.

Truncus immaculatus. Squamula piceæ. Ale hyalinæ, apice fuscescentes, nervis testaceis. Pedes nigri, albido-pilosi, anterioribus quatuor antrorsum rufis. Tarsi omnes ferruginei.

Авдомеi lanceolato-ovatum, pilis sparsis, ad latera præcipuè et anum, villosulum; segmento primo piceo, apice ferrugineo, reliquis rufopiceis, intermediis duobus utrinque maculâ introrsum acutâ, proximis tribus fasciâ abreviatâ, sulphureis. Segmentum ultimum rufum, apice bidentatum. Venter obscurè ferrugineus.

This species, in habit and stature, very much resembles the Nomada furva of $\operatorname{Panzer}(d)$; but in colour and markings it is very different, as will appear upon a comparison of his description with mine.

(d) Fn. Ins. Germ. Init. n. 55. tab. 23.

02 17. A. 
sex-cincta 17. A. atra; tarsis rufis; abdomine fasciis sex flavis, anticis tribus interruptis.

MUS. Kirly.

Long. Corp. Lin. 4.

Hal. Barhamix, semel capta.

DLSCR. Mas.

CORPUS atrum, pube grisescenti.

CApur. Maxille basi flavæ, dein rufæ, apice fuscæ. Labium rufum. Antennce rufæ, supra piceo-nigræ, scapo antrorsum maculâ flavâ. Facies immaculata, solummodo lineolà flavâ inter basin maxillaruın et oculos inclusâ.

Truncers. Tubercula vertice flava. Squamulce extrorsuin obscurè fulvescentes. Alce hyalinæ, apice fuscescentes, nervis testaceis. Pedes nigri, tibiis quatuor anticis rufis, nebulâ subannulari nigrâ. Femora primi et secundi paris antrorsum apice rufa. Tarsi omnes rufi.

Ав домеn sublanccolatum, atrum, maculis sex, per paria dispositis, anticis minutis oblongis, intermediis magnis ovatis introrsum acutis, ultimis sublinearibus, fasciisque tribus posticis, flavis. Segmentum ultimum apice bidentatum, rufum, maculà flavâ. Venter niger, fasciis tribus subrepandis, anoque, flavis.

This is very similar, at first sight, to $A$. leucophthalma; but it seems sufficiently distinguished, not to recapitulate its various slighter dissonances, by the different colour and yellow bands of the under side 
side of its abdomen; a circumstance in which insects of the same sex do not usually vary. 18. A. atra; scutelli punctis duobus, abominisque Scha. Per-
clla. maculis sex, fasciâ, anoque, flavis.

FIG. Schaffer. Icon. I. tal. 81. fig.7.

MUS. D. Marsham, J. Coyte, Kirly.

Long. Corp. Lin. $5 \frac{1}{2}$.

Hab. In Angliâ, a D. J. Coyte bis, a D. Marsham semel lecta.

DESCR. Acul.

CORPUS atrum, rufescenti-subvillosum.

CAPUT anticè, et Oculorum ambitus a parte interiori, fulvo-flavạ. Maxilla apice fuscæ. $A n$ tennce ferrugineæ, scapo supra nigro.

Truncus. Tulercula, Squamulce, Scutellum punctis duobus elevatis, fulvo-flava. Alce infuscatæ, apice obscuriores, nervis nigricantibus. Pedes rufi, tibiis flavo obscurè lituratis. Femora ferruginea, basi subtus atra. Apophyses atræ.

АвдомеN ovatum, atrum, maculis anticis subxqualibus sex, fasciisque duabus posticis, fulvo-flavis. Venter ater, segmento tertio fasciâ subrepandâ, quarto maculis duabus obliquis, quinto puucto medio, flavis.

Obs. Interdum corporis hirsuties pallescit.

19. A. atra; scutelli punctis duobus, abdominisqueconnexa, maculis sex, fasciis tribus, pedibusque, flavis.

$$
\text { o } 3 \text { FIG. }
$$


A PIS. (*. a. b.)

FIG. Nomada sexfasciata nigra, scutello punctis duobus, abdomine gibbo, fasciis sex flavis, primis tribus interruptis; antennis rufis, pedibus flavis.

Panxer. Fn. Ins. Germ. Init. n.68. tab. 18?

MUS. Kirìy.

Long. Corp. Lin. 6.

Hal. Prope Londinum, a D. Marsham lecta, et mihi transmissa.

DESCR. Mas.

CORPUS atrum, villoso-canescens.

CAPU T anticè sulphureum. Maxillae apice fusca.

Facies infra antennas villoso-argentea. $A n$ tennce ferrugineæ, supra basi dimidiato-nigræ, scapo antrorsum maculâ flavâ.

Truncus. Squamule extrorsum pallidæ. Scutellum punctis duobus minutis, distantibus, flavis. Alce subfuscæ, nervis nigris. Pedes ochracei femoribus rufis, subtus, apophysibusque, atris.

ABDONEN subovatum, supra convexum, atrum, maculis sex per paria dispositis, anticis duabus mincribus, fasciisque tribus, flavis. Segmentum ultimum integrum. Venter anticè niger, postịcè flavus et hirtus.

This species may possibly be the other sex of A. Schafferella; I am induced to consider it as distinct by the following circumstances, in which it differs from that insect, and which seem more than sexual characters. The down of its head and trunk is white and thick for this family; its antennæ, on their upper side, are black from the base 


\section{A PIS. (*. b.)}

more than half way upwards; its tubercula are black, and the exterior margin of the squamulæ is of a pale colour; the dots upon its scutellum are minute and distant; its tibiæ and tarsi are yellow; the first pair of yellow spots upon the abdomen are smaller than the other two, and the last ventral segments are more hairy than is usual in the present family. Panzer's Nomada sexfasciata may, perhaps, be a variety of it ; but, as I have doubts on that head, I have given it another trivial name.

20. A. atra; pedibus ferrugineis; scutelli punctis, Jacobace. abdominisque maculis fasciisque, flavis; antennis supra nigris.

IIG. Nomada Jacolae nigra; abdomine fasciis sex flavis, primis tribus interruptis, antennis pedibusque flavis. Panzer. Fn. Ins. Germ. Init. n.72, tab. 20.

MUS. D. Marsham, Drury Sphex, n. 68. Kirby.

Long. Corp. Lin. $5-5 \frac{1}{2}$.

$\mathrm{Hab}$. Barhamiæ, lecta tempore vernali in floribus Grossularia.

DESCR. Mas.

CORPUS atrum, pube albescenti.

$\mathrm{C}_{\mathrm{APUT}} \mathrm{T}$ anticè et lineola ante oculos, flava. Nasus barbâ albâ. Maxillıe apice fuscæ. Antennce rufæ, supra piceo-nigræ, scapo antrorsum flavo.

Truncus. Collare, Tubercula, Squamulce, Scutellum punctis duobus, flava. Ala hyalinæ, apice nigricantes; nervis, costali interiore nigro excepto, testaceis. Pedes ferruginei, fe-

$$
\text { o } 4 \text { moribus }
$$


A TIS. (*. b.)

moribus posticis ferè totis, reliquis subtus, apoplysibusque, nigris. Tibice anticæ antrorsum liturâ flavâ.

Aв DOMEN subovatum, atrum, segmento antico, maculis duabus subrepandis, vel potiùs fasciâ interuptâ, secundo maculis duabus, magnis, ovatis, tertio totidem lanceolatis, proximis duobus fasciâ, anoque, flavis. Segmentum ultimum emarginatum. Venter fasciis quinque subrepandis, flavis

Var. $\beta$ pleuris anticè maculâ rotundâ, flavâ ; abdomine segmento primo fasciâ obscurâ, inte:ruptâ, ferrugineà, maculas duas contiguas subtriangulares flavas includente.

Panzer's $N$. Jacobace appears to me merely a variety of our insect, which is sufficiently distingui hed from the preceding species, by its antennæ blackish on the upper side, its yellow tubercles and squamulx, hyaline wings, red legs, and emarginate anus.

Raro-pic-21. A. atra; antennis nigricantibus; scutelli punc;a, tis duobus contiguis, abdominisque maculis, fasciisque, flavis.

MUS. Kirly.

Jong. Corp. Lin. 5.

Hul. Barhamix, in floribus Jacolece lecta Septembre ineunti 1799 .

DESCR. Acul.

CORPUS atrum, glaberrimum.

CAPUT 
$\mathrm{C}_{\mathrm{A}} \mathrm{PU} \mathrm{T}$ anticè flavum, flavedine antennas versus subtrilobâ, lobo intermedio lato, obtusangulo, lateralibus parvis, obliquis. Labium fulvum. Maxille apice fuscæ. Punctulum flavum, obscurum, Faciem ad oculos sub antennis utrinque signat. Antennce nigræ, basi subtus rufæ.

Truncus. Collare, Tubercula, Squamula, Scutellum punctis duobus contiguis, valde elevatis, Metathorax totidem parallelogrammicis, distantibus, Pleurce maculâ subtriangulari, sulphurea hæc omnia. Ale subhyalinæ, apice nigricantes lunulâ albâ. Pedes rufo flavoque varii. Apöphyses primariæ articulo primo atro, secundo rufo, secundariæ totæ rufæ articulo primo utrinque puncto flavo, ternariæ articulo primo nigro antrorsum flave, secundo rufo.

ABDomen ovatum, atrum, segmento primo fasciâ subinterruptâ, proximis duobus utrinque maculâ introrsum acutâ, anticis majoribus, reliquis fasciâ, flavis. Venter gibbus, posticè flavus, fasciâ nigrâ.

This insect is extremely distinct from all that we have hitherto described; its body is quite naked, and its antennæ entirely black, except only the underside of two or three of the joints next the head. Peculiarities which likewise attend several of the following speeies. 
Solidagi-22. A. atra; antennis nigricantibus; scutello, abmis. dominisque maculis, fasciisque, flavis; segmen. to primo immaculato.

FIG. Nomada Solidaginis nigra, abdomine fasciis quinque flavis, primis tribus interruptis, segmento primo immaculato.

Panzer. Fn. Ins. Germ. Init. n.72, tab. 21.

MUS. D. Marsham, Lathbury. Kirly.

Long. Corp. Lin. $3 \frac{1}{2}-5$.

Hab. Barhamix, $\alpha$ nempe. Varietates $\beta, \gamma, \delta$ prope Ericetum dictum Martlesham heath juxta Woodbridge lectæ in floribus Jacolice.

DESCR. Acul.

CORPUS atrum, glabrum.

CA P U T anticè flavum, flavedine, versus antennas, trilobâ, lobo intermedio obsoletiusculo, obtusangulo, lateralibus apice latioribus, emarginatis. Maxilla apice fuscæ. Latium fulvum. Oculi, in vivo, chrystallino-albidi. Antennce nigræ, basi rufæ.

Truncus. Collare, Tubercula, Squamulce, Scutellum planiusculum, item Pleure maculâ lunatâ, flava. Pedes rufi, flavo variegati, femoribus tertii paris posticè basi nigris. Apophyses primariæ articulo primo nigro, antrorsum apice flavo, secundo rufo, intermedix totæ rufx, ternariæ articulo primo posticè nigro anticè rufo extrorsum flavo, secundo toto rufo. Puncta bina, et lineolæ totidem flavæ, regionem pedum quatuor posticorum ornant.

ABDOMEN 
A в DоMEN ovatum, atrum, segmento primo immaculato, secundo et tertio, utrinque maculâ magnâ introrsum acutâ, proximis duobus fasciâ, flavis. Venter fasciis quatuor repandis, flavis, anticâ interruptâ.

Tar. $\beta$ faciei flavedinis lobis lateralibus apice rotundatis; pedibus rufis, geniculis flavis; punctis lineolisve flavis nullis inter pedes posticos; apophysibus primariis articulo primo immaculato.

Maris Corpus albido-subvillosum. Labium flavum. Antennce scapo antrorsum flavo. $F \boldsymbol{~}$ ciei flavedinis lobi laterales apice elongati, attenuati. Alce superiores basi puncto flavo notatæ. Apophyses posticæ articulo primo antrorsum flavo. Abdomen tergo fasciis tribus posticis flavis, ventre fasciâ anticâ integrâ. Anus integer.

Var. $\beta$ minor faciei flavedine lobis lateralibus apice furcatis; abdomine maculis sex introrsum acutis, fasciisque duabus, flavis; ventre fasciâ primâ interruptâ; apophysibus posticis ut in feminâ.

$\gamma$ minor, tibiis posticis nebulà, femoribus basi subtus, apophysibusque, nigris, his articulo prima extrorsum maculâ flavâ; alis superioribus basi puncto flavo nullo; ventre $\mu \mathrm{t}$ in $\beta$.

$\oint$ abdomine segmento tergi antico punctis quatuor 
quatuor transversè positis flavis notato, aliàs $\alpha$ similis.

This gay insect varies greatly in the males, both as to size and markings, $a$ is as big again as the rest. I have some suspicion that $\delta$ may be distinct, as the first dorsal segment of the abdomen in the other varieties is constantly without spots. Panzer's $N$. Solidaginis is evidently a male variety of ours.

picta. 23. A. atra; antennis nigricantibus; abdomine ferrugineo, maculis quatuor, fasciisque duabus, scutelloque, flavis.

MUS. D. Mcrsham, Kirly.

Long. Corp. Lin. 4.

Hab. Barhamiæ, sæpius capta in floribus Septembre ineunti 1799 .

DESCR. Acul.

CORPUS atrum, glabrum.

CAPut. Os rufum. Facies anticè flava flavedine trilobâ, lobo intermedio obsoletiusculo, obtusangulo, lateralibus apice latioribus, furcatis. Gence margine apud oculos anticè flavo. Maxilla apice fuscæ. Oculi, in vivo, chrystallini, posticè albidi, anticè fusci. $A n$ tenna piceo-nigræ, basi rufæ.

Truncus. Collare, Tubercula, Squamula, Scutellum, Pleurce maculâ lunatâ, Pectus punctis duobus triangularibus, totidemque lineolis in pedum posticorum regione, flava omnia hæc. 
Alce fuscescentes, apice obscuriores lunulâ albâ, nervis nigris. Pedes ferruginei, femorum apicibus, tibiarumque liturâ externâ, flavis. Femora ultimi paris posticè nigra. Apophyses primariæ articulo primo nigro, apice flavo, secundo rufo, secundariæ rufæ, articulo primo puncto flavo, ternariæ anticè rufæ maculâ laterali sulphureâ.

АвдомеN ferrugineum, maculis quatuor magnis anticis introrsum acutis, fasciisque duabus posticis, sulphureis; segmento ultimo et antepenultimo margine nigricantibus. Venter ferrugineus, fasciis tribus flavis anticâ interruptâ.

Obs. Abdominis tergi et ventris segmentum primum immaculatum.

24. A. atra; antennis nigricantibus; abdominerufo-picferrugineo, maculis sex, ano, scutelloque, ${ }^{\ell a}$. flavis.

MUS. Kirly. Long. Corp. Lin. $3 \frac{x}{4}$.

Hal. Barhamix ? semel lecta.

DESCR. Acul.

CORPUS atrum glabriusculum.

$\mathrm{C}_{\mathrm{APU}} \mathrm{T}$ anticè ferrugineum. Maxilla basi flavæ, dein rufæ, apice fuscæ. Antenna piceo-nigræ, basi rufæ.

Truncus. Collare, Tulercula, Squamula, Scu.. iellum, Pleure puncto, flava. Ala hyalinæ, apice nervisque nigricantibus. Pedes rufi, femoribus 
moribus ultimi paris posticè nigris. Apophyses rufæ, primariis articulo primo nigro, ternariis articulo primo posticè nigro, maculà laterali sulphureâ.

АвдомеN ferrugineum, segmento primo basi nigro, proximis tribus utrinque maculâ introrsum acuta, anoque, flavis. Venter gibbus, ferrugineus, fasciis quatuor angustis, flavis, anticâ interruptâ, segmento primo immaculato.

Obs. Maculce duce postica abdominis tergi fere lineares, fasciam medio interruptam efficientes.

This species somewhat resembles $A$. picta; but, although of the same sex, it is not more than half as big; the apex of the face is ferruginous, the pleuræ have only a round yellow dot, the legs are not variegated with yellow, and the abdomen is distinguished by six pair of yellow spots, the last forming an interrupted fascia.

Hillana. 25. A. atra; labio, squamulis, scutelloque, ferrugineis; abdomine rufo, maculis quatuor, fasciisque tribus, lutescentibus.

MUS. D. Hill.

Long. Corp. Lin. $4 \frac{1}{2}$.

Hab. In Angliâ, a D. Hill Londinensi, collectori assie duo, lecta.

DESCR. Mas.

CORPUS atrum, villoso-canescens.

CAP U t antice, Frontis anguli, Gencrque antrorsum, lutex. Labium rufun. Maxilice basi

flava, 
A P I S. (*. b.)

flavæ, dein rufæ, apice fuscæ. Facies ante antennas pilis argenteo-nitidis barbata. $A n$ tenna ferrugineæ, scapo nigro.

Truncus. Collare utrinque, Tubercula, Squamula, Scutellum, ferruginea. Alce subtestaceæ, apice fuscæ lunulà albâ; nervis, costali interiore fusco excepto, ferrugineis. Pedes rufi, femoribus posticis, anterioribus quatuor subtus, apophysibusque, nigris.

Авдомеn lanceolatum, pilosulum, rufum, maculis quatuor lateralibus, duæ utrinque, fasciisque tribus, (anticấ medio, intermediâ lateribus et medio, interruptis, ultimâ continuâ) luteis. Anus bidentatus. Venter rufus, basi niger, maculis, fasciisque, luteis variegatus.

26. A. atra; scutello sanguineo; abdomine rufo, ochrostomaculis fasciisque interruptis, flavis, variegato. ${ }^{m a}$.

MUS. D. Drury Sphex, n. 55. Kirby.

Long. Corp. Lin. $4 \frac{2}{3}$.

Hal. In Angliâ, a D. Drury lecta.

DESCR. Mas.

CORPUS atrum, pube albidâ subincanum.

Caput. Facies anticè, Labium, Genarum apex, sulphurea. Maxille basi flavæ, dein rufæ, apice fuscæ. Nasus argenteo barbatus. Antennce rufæ, supra basi dimidiato-nigræ.

Truncus. Collare, Tubercula, Squamula rufa. Scutellum sanguineum. Alce testaceæ, apice fuscæ lunulâ albâ; nervis, costali interiore ni- 
gro excepto, rufis. Pedes rufi, femoribus posticis totis, anterioribus quatuor basi subtus nigris. Apophyses rufo nigroque variæ.

А в домеN lanccolatum, rufum, segmento primo basi nigro, secundo maculis binis rotundatis, tertio totidem ovalibus, proximis duobus fásciâ interruptâ, sexto fasciâ continuâ, sulphureis. Anus apice bidentatus. Venter rufus, posticè punctis sulphureis quatuor, quadratim positis.

This approaches very near to the preceding species; but, as they are of the same sex, and differ in many respects not a little, I think they are distinct. I have, as yet, had no opportunity of comparing the specimens themselves.

ruficornis.27. A. ferruginea; thorace lineis tribus longitudinalibus atris; abdomine maculis, fasciisque, flavis.

Apis ruficornis antennis, pedibusque duobus, punctısque thoracis ferrugineis, abdomine luteo variegato.

Lin. Syst. Nat. ed. 12. n.34. Fn. Suec. 1707.

Vill. Ent. Eur. 3. n. 27.

Nomada ruficornis antennis, pedibus, scutellique punctis quatuor ferrugineis, abdomine luteo variegato.

Fab. Ent. Syst. Em. n.7.

Lin. Syst. Nat. ed. Gmel. p. 2795. Apis, n.34.

Vespa rubra, thorace lineolis longitudinalibus nigris, - abdomine maculis flavis.

Geollir. Hist. Ins. Par. tom. 2. p. 3s1. n. 18.

lespa rulra. Fourcroy. Ent. Par. n.18.,

FIG. Nomada ruficornis. Panzer..Fn. Ins. Germ. Init. n.55. tal. 18. 
MUS. D. Smith Linnean. Marsham, Latham, McLeay, Sowerby, Lathlury, Trimmer, Kirly. Long. Corp. Lin. $4-5 \frac{1}{2}$.

$H a b$. Barhamiæ, sed rara, prope Londinum frequentior.

DESCR. Acul.

CORPUS nigro, ferrugineoque varium, albidosubvillosum.

Caput. Antennce ferrugineæ. Maxill ce apice fuscæ.

Truncus. Thorax ferrugineus, lineis tribus longitudinalibus atris, anticè et posticè concurrentibus, inscriptus. Metathorax utrinque maculâ villoso-albâ. Ala fuscescentes, apice obscuriores lunulâ albâ. Pedes ferruginei, femoribus posticis ferè totis, anterioribusque quatuor su? tus, nigris.

Aв DOMEN Ovato-lanceolatum, ferrugineum, segmento primo basi apiceque nigro, proximis duobus utrinque maculâ introrsum acutâ, anteriori majori, quarto fasciâ abbreviatâ, quinto maculâ magnâ quadratâ, flavis. Venter gibbus, ferrugineus, segmentis margine medio nigricantibus

$V$ ar. $\beta$ ventre punctis duobus flavis notato.

$\gamma$ metathorace nigro; abdomine segmento secundo utrinque maculâ rotundatâ, flavâ. Aliàs $\alpha$ similis.

$\delta$ minor, artennis supra nigricantibus ; metathorace atro; alis subhyalinis; apophysibus nigricantibus; abdomine ovato, segmento 
mento secundo punctis duobus, tertio totidem utrinque, penultimo maculis binis dorsalibus, luteis. An eadem ?

Linneus regarded almost all the species that compose this family merely as varieties of his $A$. ruficornis; the one I have just described is particularly noticed by him as such in his Fauna Suecica, "Thorax niger, says he, " aliis linece ferruginece quatuor longitudinales." Terms which will exactly suit our insect; as in fact the thorax exlibits four ferruginous lines separated by three black ones, but as the ferruginous colour is predominant, I have reversed the characters. This insect stands with others in the Linnean cabinet under the above name. Induced by these circumstances, after Fabricius, I have selected this, from the rest, to give as $A$. ruficornis.

Panzer's figure of this insect is tolerably accurate, but in my copy the red parts are made too pale and glaring. It is a varying species, but may always be distinguished by its body variegated with black and red, in rearly equal proportions, and by the three black parallel lines inscribed upon the thorax. Variety $\delta$ differs considerably from the rest both in the form and markings of its abdomen, but as it agrees with them in these particulars, I have not considered it as distinct.

28. A. atra ; antennis, scutellique punctis, ferrugisticta. neis; abdomine rufo, maculis duabus flavis.

MIUS. 
MUS. D. Latham.

Long. Corp. Lin. $3 \frac{1}{2}$.

$H a l$. In Angliâ, a D. Latham capta.

DESCR. Acul.

CORPUS atrum, glabriusculum.

Cарчт. Maxille Labiumque, ferruginea. $A n-$ tennce ferrugineæ, supra basi, scapoque toto, nigræ

Truncus. Tubercula flava. Squamula rufæ. Scutellum punctis duobus, elevatis, obscurè ferrugineis. Alce subhyalinæ, apice obscuriores, nervis nigricantibus. Pedes picei, tibiis antrorsum, digitisque, rufescentibus.

Ав Dомеn subovatum, ferrugineo-rufum, segmento primo basi nigro, secundo utrinque maculà rotundâ flavâ. T'enter rufus, immaculatus.

29. A. atra; antennis rufis, nigro annulatis; abdo-Fabriciel. mine ferrugineo maculis duabus flavis.

La.

Apis Falriciana nigra, abdomine glabro, ferrugineo, maculis duabus flavis.

Lin. Syst. Nat. ed. 12. छ Gmel. p. 2794. n. 17.

Vill. Ent. Eur. 3. n. 14.

Ross. Fn. Etrusc. Mantiss, n. 324.

Nomada Fabriciana. Fal. Ent. Syst. Em, n, 10.

FIG. Tab. 16. fig. 3.

MUS. D. Marsham, Trimmer, Kirby.

Long. Corp. Lin. 3-4.

Hab. Barhamiæ, sed rarissima, prope Londinum satis frequens,

DESCR, 
DESCR. Acul.

CORPUS atrum, albido-subvillosum.

CAPUт immaculatum. Facies anticè pilis sparsis, atris consita. Gence albido densiùs barbatæ. Antenne rufx, basi, annuloque apicem versus, nigris. Oculi, in vivo, chrystallinofusci.

Truncus immaculatus. Squamula ferrugineæ. Alc infuscatæ, apice nigræ lunulâ albâ. Pedes nigri, tibiis antrorsum, femoribus anticis apice, digitisque, ferrugineis.

$\Lambda_{\text {в DOMEN ferrugincum, basi nigrum, segmento }}$ secundo utrinque maculâ rotundâ, tertio puncto obscuro, flavis. Venter ferrugineus, immaculatus.

$V a r . \hat{s}$ antennis supra nigricantibus, articulo extimo fulvo; squamulis nigris, tibïs tantùm anticis antrorsum rufescentibus.

$\gamma$ minor; maculis punctisque flavis abdoininalibus ferè obsoletis.

I have very little doubt as to the claim of this insect to be considered as the $A$. Fabriciana of Linneus: I have changed this name to Falriciella, in pursuance of the plan mentioned in the preface to this work. As I do not recollect ever sceing a figure of our Apis, I have caused one to be engraved.

q'a tri- 30. A. atra; abdomine ferruginco, maculis quatuor i.otata.

flavis; antennis, pedibusque, nigris.

MUS. D. Marsham, Kirly. 
Long. Corp. Lin. 4.

Hal. Barhamiæ semel lecta. Capta etiam a D. Marsham, Julio ineunti, 1801, in Sylvâ dictâ Combe Wood, prope Kingston Surriens.

\section{DESCR. Mas.}

CORPUS atrum, albido-villosulum.

CAPut immaculatum, villosum. Antennce nigræ, subtus obscurè fulvescentes, scapo toto nigro.

Truncus immaculatus. Alce subhyalinæ, apice, nervisque nigricantibus. Pedes nigri, tibiis quatuor anticis antrorsum, digitisque, rufescentibus. Anus bidentatus

Ав Dомen ovatum, pilosulum, segmento primo nigro fasciâ ferrugineà, reliquis ferrugineis, secundo et tertio apice nigricantibus utrinque maculâ rotundâ flavâ notatis. Venter ferrugineus, immaculatus.

Obs. Annon A. Fabricielle mas?

31. A. atra; antennis fulvis; abdomine rufo, punc-ficuro-guttis quatuor luteis.

MIUS. D. Marsham, Kirly.

Long. Corp. Lin. $2 \frac{1}{2}$.

Hal. Barhamiæ rarissima.

DESCR. Mas.

CORPUS atrum, albido-subvillosum.

CAPUT anticè flavidum. Maxillce apice rufæ. Labium nigricans. Facies ante antennas piloso-argentea. Antennce thoracis longitudine, fulvo-rufæ, basi supra, scapoque toto, nigris. 
Truxcus immaculatus. Squamula picex. Aice hyalin $x$, apice, nervisque, nigris. P'edes fulvorufi, femoribus quatuor posticis ferè totis, anticis subtus, tibiisque hinc, nigro-piceis.

AвDOMEN subovatum, rufum, segmento prima basi nigro, proximis duobus utrinque maculá parvâ lutescenti. Anus apice bidentatus. $V$ enter rufus fasciis obsoletiusculis, pallidioribus.

rufo-cinc-32. A. atra; scutello ferrugineo; abdomine fusco, ta. punctis quatuor luteis; fasciâ, ventreque, rufis.

MUS. D. MFarsham, Kirly.

Long. Corp. Lin. $2 \frac{1}{2}$.

$\mathrm{Hal}$. Barhamiæ, in aggere aprico capta.

DESCR. Acul.

CORPUS atrum, glabriusculum.

$\mathrm{CAPUT}_{\mathrm{T}}$ anticè, et oculorum ambitus, ferruginea, Labium nigricans. Antenna ferruginex, subtus pallidiores, scapo supra nigro.

Truncus. Collare, Tulercu'a, Squamule, striga utrinque ante alas, Pleur.e, Pectus inter pedes quatuor posticos, Scutelli puncta duo, et lineola transversa elevatiuscula, ferruginea hæc omnia. Metathorax utrinque maculâ villosoniveâ. Alce subhyalinæ, apice nerrisque nigris, lunulâ altâ. Pedes picei, tibiis tarsisque quatuor anticis antrorsum fulvo-flavis.

ABDomen subglobosum, fusco-piceum, fasciâ anticâ rufâ utrinque puncto nigro notato, segmonto secup̧do utrinque maculâ parvâ, tertio 
puncto, luteis. Venter ferrugineus, immaculatus.

33. A. atra; scutello ferrugineo; abdomine fusco, Sheppardimmaculato.

MUS. D. Marsham, Trimmer, Kirby.

Long. Corp. Lin. $2 \frac{1}{2}$.

$H a b$. Barhamix, in aggeribus apricis obvia.

DESCR. Acul.

CORPUS atrum, glabriusculum.

$\mathrm{C}_{\mathrm{APU}} \mathrm{T}$ anticè, et oculorum ambitus, ferruginea.

Labium ferrugineum. Antenne rufo-fulvæ, supra, articulo extimo fulvo excepto, piceæ.

Truncus. Collare obscurè, Tubercula, Squamulce, Pleurce, Pectus inter pedes posticos, Scutelli puncta duo, et lineola transversa, elevatiuscula, ferruginea omnia. Metathorax utrinque maculâ villoso-niveâ. Alee infuscatæ, apice nervisque n!gris, lunulà albâ. Pedes picei tibiis, tarsisque quatuor anterioribus, illæ tantùm antrorsum, rufis. Apophyses rufo variæ. Femora antica ctiam antrosum rufa.

Ав ромеn subglobosum, supra et infra fuscum, infra tamen dilutiùs, immaculatum.

Revetti Sheppard, A.B. juvenis ingenui, olim discipuli mei dilecti, insectorum collectoris indefessi, oculatissimi, hac Apis nomen gerit.

This is the smallest species of this family with which I am, at present, acquainted; it is extremely similiar in most respects to the preceding, and may, 
possibly, be only a variety of it; but as its abdo. men is only of one colour, without either red fascia, or yellow spots, besides slighter differences, I thought it most adviseable to give it as distinct.

ferrugi- 34. A. atra; antennis, pedibus, abdomineque, ferrugineis; labio subcornuto.

Apis ferruginala nigra, glabra, abdomine, antennis, ore, pedibusque ferrugineis.

Lin. Syst. Nat. ed. 12. E' Gmel. p. 2779. n. 35.

Vill. Ent. Eur. 3, n. 28.

Forst. Cat. Brit, Ins. n.723. Apis, n. 18.

FIG. Tal. 16. fig. 4.

Nomada Germanica atra, abdomine rufo, basi nigro; pedibus nigris, rufo annulatis.

Panzer. Fn. Ins. Germ. Init. n. 72. tab.17.

MUS. D. Smith, Kirly.

Long. Corp. Lin. 4.

Hab. Prope Londinum, a D. Marsham semel lecta.

DESCR. Mas.

CORPUS atrum, albido-subvillosum.

Cарит. Os fulvum. Labium pilosum, nigrum, mucrone brevi, acuto, sine lente et nisi a latere vix conspicuo, armatum. Antennce breviusculæ, ferrugineæ, scapo nigro.

Truncus. Tulercula et Squamulce ferruginea. Scutellum tubercula duo valde elevata gerit. Ala subhyalinæ, apice nervisque nigricantibus, lunulâ albâ. Pedes ferruginei, apophysibus, femoribusque posticis ferè totis, anterioribus quatuor subtus, tibiisque ultimi paris apice, n̨igris.

ABDOMEY 
AвDOMEN subovatum, ferrugineum, basi, maculisque duabus anticis lateralibus, nigris. Ani extremitas truncata. Venter ferrugineus, segmentis omnibus basi fasciâ abbreviatâ nigrâ.

There is no authentic specimen of this species in the Linnean cabinet; what is now there as such was labelled by the present worthy possessor, but it answers the description of Linneus very well. The tubercula of this and the Linnean insect are yellow; in our specimen, which I owe to the liberality of Mr. Marsham, these are ferruginous. In other respects they agree together. Fabricius has omitted this species, perhaps he took it for a variety of $A$. Fabriciella, from which it is, however, extremely distinct. Forster introduces it into his catalogue of British insects. Panzer's Nomada Germanica comes very near to it, if it be not the same.

The horn upon the lip of this species seems to indicate that it ought to be placed near to $A$. çornigera, \&c. but in habit and other respects, it appears to be more nearly related to those last described.

$$
\text { **. a. }
$$

35. A. aterrima, albido-villosa; abdomine segmen-punctata. tis utrinque puncto albo; scutello bidentato.

Apis punctata nigra, cinereo-villosa; abdomine atro \$egmentis utrinque puncto albo.

Fab. 
A PIS. (* *. a.)

Fat. Ent. Syst. Em.n. 99.

Lin. Syst. Nat. ed. Gmel. p. 2771. n. 59.

Vill. Ent. Eur. 3. n. 62.

Apis allifrons pubescens, fronte, thorace, tibiis puncr tisque abdominis, albis.

Forst. Cent. Insect. n. 94.

Cat. Brit. Ins, n.721. Apis, n. 15.

Lin. Syst. Nat. ed. Gmel. p. 2787. n. 144.

Apis nigra; thorace hirsuto canescente; abdomine gla briusculo, punctis utrinque quatuor albis.

Mill. int. Not. M. S. Graian. supr. citat.

Apis sylvestris, minor, corpore oblongo, maculis ad la. tera et in cruribus, albis.

Rai. Hist. Ins. p. 243.

FIG. Scha.f. Icon. tab. 22. fig. 14.

Harris. Exp. tal. 40. fig. 11.

Panzer. Fn. Ins. Germ. Init. n. 35. tal. 23.

Mas. Tal. 16. fig. 5.

MUS. D. Marsham, Latham, Haworth, Trimmer, Lathbury Francillon, Sowerly, Coyte $\gamma$, Kirly.

Long. Corp. Lin. 6-7.

Hal. Barhamiæ, in floribus, ripis apricis induratis, murisque e luto confectis, obvia. Ova deponit, uti suspicor, in cellulis Apis retusce, Cuculus Apum.

DESCR. Acul.

CORPUS aterrimum, supra pube albidâ variegatum.

CAPUT subtus atro, supra albido barbatum, Labium posticè punctis duobus fenestratis insigne. Antenne nigræ articulis subarcuatis.

Truncus. Thorax anticè, item Pleura, hirsutie densâ albâ. Scutellum bidentatum, dentibus sub 
sub hirsutie atrâ delitescentibus, sine tactu vix agnoscendis $(e)$. Metathorax utrinque albidovillosus. Squamule atræ. Alce subhyalinæ, fusco nebulosæ, apice nigricantes; nervis nigris, crassiusculis. Pedes atri, tibiis anticis totis, posterioribus quatuor basi, extrorsum tomentoso-albis; intermediæ liturâ tomentoso-flavescente apicem versus insuper notantur. Digiti picei, pilis albidis incani. Scopulce fuscæ, obscuræ.

АвDоMEN breve, ex cordato ovatum, acutum, aterrimum, nitens, punctulatissimum, pilis sparsis, rigidiusculis, atris conspersum, segmentis margine crassiusculis, duobus anticis utrinque maculâ villosâ, proximis duobus puncto tomentoso, albis.

Obs. Puncta labialia fenestrata vix detegenda, nisi in lailio seorsìm conspecto.

Var. $\beta$ faciei et trunci hirsutie atrâ; thorace literâ $\mathrm{T}$ al̉bicâ inscripto.

$\gamma$ corporis hirsutie totâ atrâ, abdomine utrinque punctis tantùm tribus albis. An eadem ?

Maris Corpus hirsutie cinereâ, scutelli tantùm atrâ. Tilice intermediæ extrorsum totæ tomentoso-albidæ. Plante etiam pilis decumbentibus incanæ. Aldomen segmento prima finereo-villoso. Anus subemarginatus.

(c) Tab. 6. **, a. fig. 2. $a a$. 


\section{**. b.}

variegata.36. A. nigra; trunco, abdomineque, albido variegatis; pedibus ferrugineis.

Apis variegata thorace abdomineque albo variegatis, pedibus ferrugineis.

Lin. Syst. Nat. ed. 12. E Gmel. p. 2794. n. 24. Fn. Suec. n. 1699.

Vill. Ent. Eur. 3. n. 20.

Forst. Cat. Brit Ins. n. 1033. Apis, n. 26.

Nomada variegata. Fal. Ent. Syst. Em. n. 5 .

FIG. Nomada crucifera atra cinereo-pubescens, abdomine atro, segmento primo fasciis duabus, secundo unicâ, interruptis, reliquis maculis quaternis albis, pedibus ferrugineis.

Panzer. Fn. Ins. Germ. Init. n. 61. tab. 20.

Apis muscuria. Christii Hymenopt. p. 195. tal. 17. fig. 5.

Tab. 16. fig. 6.

MUS. D. Smith Linnean, Marsham, Latham, Drury Apis 56, Sowerby; Trimmer, Lathbury, Kirby.

Long. Corp. Lin. 4.

$\mathrm{Hab}$. Barhamiæ, in viarum aggeribus apricis Augusto ineunti 1797,1799 , capta, sed minùs frequens. Pernoctat in Geranii phai rostris mordicùs apprehensis. Linn.

DESCR. Acul.

CORPUS nigrum, obscurum.

CAPUT albido-pilosulum. Maxilla ferruginex. Oculi, in vivo, incarnato-chrystallini. Antenne piceo-nigræ.' Facies circa basin antennarum tomentoso-argentea.

Truncus glabriusculus. Collare utrinque tomentoso-lutescens. Thorax anticè lineolis duabus 
duabus tomentoso-lutescentibus inscriptus, posticè dentibus duobus ferrugineis, vix conspicuis, scutellum utrinque amplectentibus, armatus $(f)$. Tubercula, Scutellum, Squamulce ferruginea. Metathorax verticalis, utrinque maculâ tomentoso-niveâ ornatus. Pectus circa pedum basin, item Pleurce sub alis, tomentoso-alba. Ala subhyalinæ apice nervisque nigris, lunulâ albâ. Pedes ferruginei, pilis brevissimis albidis subincani.

Ав ромеn basi,subretusum, supra gibbum, segmento primo fasciis duabus interruptis, intermediis tribus maculis quatuor transversè positis, tomentoso-lacteis. Venter piceus.

$V$ ar. $\beta$ femoribus posticis totis, intermediis subtus, piceis; abdomine segmenti secundi maculis in fasciam medio interruptam coalescentibus.

$\gamma$ labio obscurè ferrugineo; thoracis dentibus atris; abdomine segmenti primi fasciis utrinque coalescentibus.

Our English specimens of this singulariy pretty insect vary somewhat from the authentic $A$. variegata of the Linnean cabinet; for the scutellum of the latter is black, and it has more white hairs upon the anterior part of its thorax ; it is, likewise, considerably smaller. In other respects they agree very well together.. Panzer's Nomada crucifera is evidently nothing more than a casual variety of this

(f) Tab.6,**. b. fig. 8, $l$.

Apis. 
A PIS. (**. b. c. 1. a.)

Apis. His figure does not give the teeth upon the posterior part of the thorax on each side of the scutellum, but these are easily overlooked. Christius's figure, of what he calls $A$. variegata major, belongs to an insect resembling $A$. luctuosa; but which is very different from the genuine $A$. variegata: his $A$. muscaria is a tolerable representation of it.

I first saw this bee in the cabinet of Mr. Drury, and afterwards found it, but by no means common, in the autumn of two succeeding years, 1797 and 1798, flying about sunny banks; since then I have not met with it.

\section{**. c. 1. $\alpha$.}

conica. 37. A. atra; scutello bidentato; abdomine conico segmentis margine albidis; ano femineo acutissimo, masculo multidentato.

\section{ACUL.}

Apis conica fusca, abdomine conico acutissimo, segmen. torum marginibus albis.

Lin. Syst. Nat. Ed. 12. n. 32. Fn. Suec. 1705.

Vill. Ent. Eur. 3. n. 25.

Miill. Zool. Dan. n. 1908.

Schrank. Enum. Ins. Austr. n. 809.

Forst. Cat. Brit. Ins. n. 719. Apis, n. 13.

Berkenhout. Synops. 1. p. 159. n. 5.

FIG. Apis lidentata atra, nitida, abdomine conico acutissimo, segmentorum marginibus albis scutello bidentato.

Panxer. Fn. Ins. Germ. Init. n. 59. tal.7. .

Harris. Exp. Eng. Ins. tal. 49. fig. 8. 
APIS. (**. c. 1, $\alpha$.

Christii Hymenopt. tab. 17. fig. 11 ?

B. Tal. 16. fig.7.

MUS. D. Smith Linnean, Marsham, Trimmer, Latham, Francillon, $M^{c}$ Leay, Kirby.

MAS.

Apis quadridentata fusca, abdomine cingulis quinis al. bidis, ano quadridentato intermediis bifidis.

Lin. Syst. Nat. Ed. 12. E' Gmel. p. 2773. n. 29. Fn. Suec. 1703.

Fal. Ent. Syst. Em. n. 112.

Vill. Ent. Eur. 3. n. 24.

Ross. Fn. Etrusc. n. 928.

Forst. Cat. Brit. Ins, n.718. Àpis, n. 12.

FIG. Schaeff. Icon. tab. 32. fig. 8. Opuscula tab. 40. fig.6.

Panzer. Fn. Ins. Germ. Init. n.55. tal. 13.

MUS. D. Smith Linnean, Marsham, $M^{c}$ Leay, Haworth, Trimmer, Kirby.

Long. Corp. Lin. $4 \frac{1}{2}-6 \frac{1}{2}$.

$\mathrm{Hal}$. Barhamiæ. Uterque sexus flores frequentat, sed rariùs.

DESCR. Acul.

CORPUS atrum, albido-subvillosum, totum punctis excavatis quasi granulatum.

Caput. Maxille apice tridentatæ $(g)$. Facies pube, densâ admodum, grisescenti. Antennce nigræ, thorace breviores.

Truncus supra pube haud densâ grisescenti. Squamule atræ. Scutellum utrinque dente incurvo armatum. (h). Alce subhyalinæ, fusco nebulosæ, apice nervisque nigricantibus. $P e-$ des pilosuli, femoribus anticis densè barbatis. Scopulce fulvæ. Tibice spinulis atris.
(g) Tab. 7. **. c. 1, $\alpha$, fig. 6 .
(h) Ibid. fig. 10.

AR DOMEXY 
Aв domen conicum, nitidum, segmento primo utrinque maculâ, reliquis margine, tomentosoalbidis. Segmentum ultimum lineâ longitus dinali elevatiusculâ. Anus acutissimus. Venter segmento primo maculâ mediâ; reliquis margine, tomentoso albidis, ultimo elongato segmento anali dorsali longiore.

$V$ Var. $\beta$ minor; corpore aterrimo; scutelli dentibus subobsoletis; alis vix nebulosis, nervis piceis anastomosi testaceâ; tibiarum spinulis testaceis; abdomine segmentis margine utrínque tomentoso-niveis.

Maris Facies pube densiore flavescenti, anticè pallidiori, tecta. Ala nervis piceis. Tilia spinulis ferrugineis. Apophyses anticæ articulo primo mucrone caput spectante instructo. Abdomen segmento primo utrinque, proximis tribus margine, tomentoso-pallidis, ultimo quadridentato dentibus intermediis furcatis $(i)$. $V$ enter segmentis margine tomentoso-albidis.

$V a r . \beta$ minor, abdomine segmentis utrinque margine tomentoso-albis; ano sexdentato.

$\gamma$ minor; corporis pube albâ; abdomine segmentis tam ventralibus quam dorsalibus utrinque margine tomentoso-niveis; ano sexdentato.

Obs. In his varietatilus abdominis segmentum penultimum utrinque dente minuto instructum.

(i) Tab. 7. fig. 13, 1.4. 
A P I S. (**. c. 1, $\alpha$.

I observed above $(k)$, that $A$. conica and quadridentata were male and female, it will perhaps be expected that I should here assign the reasons which induced me to adopt this opinion.

Any one who compares these two insects together, will immediately perceive between them the most striking resemblance, and that the only difference arises from the anal spines or teeth, and more thickly coated face of $A$. quadridentata. Now as these circumstances are common distinctions of the male sex in all the subdivisions of this family, they will not furnish a sufficient reason for separating insects which are so very similar in other respects, without specimens of each sex can be produced, distinguished in one instance by an acute anus, and in the other armed with anal spines; but as those which exhibit the former character are invariably aculeates, and those that possess the latter as invariably males, I think this alone will sufficiently justify me for putting them together. Rossi; although apparently not aware of the difference of sex of these two insects, seems to think $A$. quadridentata a variety of $A$. conica. "Alia," says he, under $A$. conica, "præterea specimina habemus, staturâ et habitu omnino prioribus simillima, quæ cum habeant abdomen conicum, atrum, marginibus incisurarum quinque albis, anum quadridentatum dentibus intermediis bifidis, $A$. quadridentate nomine determinari possent.

(k) Vol. 1. p. 153.

VOL. II。 
A PIS. (**. c. 1. a.)

In confirmation of the above opinion, I have been informed by Mr. James Trimmer, so frequently mentioned in these pages, that he has often observed $A$. quadridentata attendant upon $A$. conica.

The authentic specimen of $A$. conica preserved in the Linnean cabinet has teeth upon its scutellum, and, therefore, that which Fabricius has given as such, "scutello inermi," is another insect, and probably the aculeate of that which I shall next describe. To this I have referred also the synonyms of Gmelin and Rossi for the same reason. Panzer's $A$. lidentata is the Linnean $A$. conica. Iinneus has described $A$. quadridentata " cingulis quinis albidis," all my specimens have only four white bands, the first of which is interrupted: Panzer's figure however answers the Linnean character in this respect, and Rossi notices the same circumstance. Probably the down upon the margin of the last segment but one is liable to be rubbed off.

There are three synonyms to which reference is usually made for the sexes of $A$. conica, which have no relation to that species. The first is that of Ray $(l)$, which belongs either to a Sphex, or a male of my family of Apis. *. b. perhaps to A. Goodeniana. The next is that of Reaumur $(m)$, (which, as as I observed above, is the male of one of the leaf

(l) Rai. Hist. Ins. p. 252. n. ult.

(m) Tom. 6. tab. 11. fig. 2, 3, 4 .

cutters; 
A P IS. (**. c. 1. a.)

cutters, with a quadridentate anus), to which Linneus referred as synonymous with $A$. conica, it is probable, from a hasty view of the figure which somewhat resembles that insect. The last is that of Swammerdam $(n)$, whose figure is quoted by Linneus and others after him both as $A$. quadridentata and $\dot{A}$. manicata; buit the figure, although a bad one, evidently belongs to the latter insect.

Variety $\beta$ of the aculeate sex, and $\gamma$ of the male, may be the sexes of a distinct species, but they so nearly resemble the others that, without fuller evidence, I was unwilling to sepärate them.

38. A. atra; scutello inerini; abdomine masculoinermis. lineari, segmentis margine albis; ano multidentato.

\section{ÀCÚL:}

Ajis conica fúsca, abdomine conicó acutissimo; segment torum marginibus albis scutello inermi.

Fab. Ent. Syst. Em. n. 116.

Lin. Syst. Nat. ed. Gmel. p. 2779. n. 32.

Ross. Fn. Etrusc. n. 928.

FIG. Apis centuncularis acuminata. Christii Hymenopt! p.192. tab.17. fig.2.

MAS:

Apis quadridentata. Miller int. Not. M.S. Graian! supr. citat.

FIG. Tal. 16. fig. 8.

MUS. Kirly.

Long. Corp. Lin، 4.

Hal. Brentfordiæ, a D. J. Trimmer semel capta。

(n) Swamm, Bib. Nat, tab. 26. fig. 4.

a 2

DESCR, 
DESCR. Mas.

CORPUS atrum, pube albidâ canescens, punctulis excavatis quasi granulatum.

CAPUT. Facies ante antennas pube cinerascenti tecta. Oculi pilosi.

Truncus. Scutellum inerme. Squamule atræ. Alce fuscescentes, nebulosæ, apice obscuriores, nervis nigris anastomosi ferrugineâ. Pedes pilosuli, tibiarum spinulis testaceis. Apophyses anticæ articulo primo antrorsum mucronato.

Авдомех lineare, subcylindricum $(n)$, cingulis quatuor tomentoso-niveis, supra interruptis infra continuis, ano quadridentato dentibus intermediis furcatis, segmento penultimo dente marginali utrinque instructo.

I have not yet met with the aculeate sex of this species, but I do not hesitate to give it as the $A$. conica of Fabricius, Gmelin, and Rossi, although not of Linncus. The circumstance which principally distinguishes it from the preceding species, is the absence of the tooth on each side of the scutellum, which constantly attends all the varieties of that insect. The abdomen of the male is likewise of a different form, and its dorsal white fascix are interrupted. Miller, in Mr. Gray's interleaved edition of the Systema Naturæ, has described an insect as $A$. quadridentata, very similar to the male of our $A$. inermis, if it be not the same, in these

(n) Tab. 7. **. c. 1, a. fig. 15. 
words. "Caput et thorax nigri supra, punctisque excavatis confertis quasi granulati, pilis lateralibus subcinereis. Frons hirsuta, alba. Oculi ovati, pallidi. Abdomen nigrum, glabrum, granulatum, conicum, cingulis tomentoso-albis, supra interruptis, infra continuis. Anus dentibus duobus bifurcatis terminatur, segmentum penultimum etiam dente utrinque gemino, ita ut abdomen apice octo-dentato appareat. Antennæ pedesque nigri tarsis glaucis.”

$$
\text { **. c. } 1 . \beta \text {. }
$$

39. A nigra, punctulatissima; scutello bidentato; prnctulaabdomine segmentis margine decoloribus. tissima.

FIG. Tul. 16. fig. 9 .

MUS. D. Marsham, Trimmer, Francillon, Kirly. Long. Corp, Lin. 3 $\frac{1}{2}-4 \frac{1}{4}$.

Hal. Barhamiæ, tempore autumnali bis capta.

DESCR. Acul.

CORPUS piceo-nigrum, totum excavato-punctulatissimum, subtus pube haud densâ cinerascenti.

Caput cinereo-villosum. Proboscis thoracis longitudine. Antennce capite longiores, nitidæ, piceo-nigræ.

Truncus. Thorax subpilosus, lineâ intermediâ longitudinali obsoletiusculâ exaratus, apud scutellum utrinque dente obsoleto instructus. Scutellum prominens, subemarginatum, punctis majoribus notatum. Squamule nigræ, ni-
Q 3
tidissimæ. 
APIS. (**. c. 1. B.)

tidissimæ. Ala infuscatæ, latere exteriori atro-violascentes, apice nervisque nigris. $P e-$ des cinereo-pilosuli.

АвDOMEN arcuatum, supra valde convexum; basi subretusum, pilis brevissimis sparsis consitum, segmentis quatupr anticis margine glabris, exalbidis, $\int$ : decoloribus. Venter planiusculus, glaber.

phaapte- 40. A. atra, punctulatissima; albido-subpubescens; $r a$. ano rectangula.

MỤS. D. Marsham, Trimmer, Françillon, Hill, Kirly.

$$
\text { Long. Corp. Lin. } 4 \frac{1}{2} \text {. }
$$

Hal. Barhamiæ, Augusto exeunti 1799 lecta, sæpius etiam prope Londinum.

DESCR. Acul.

CORPUS atrum, excavata-punctulatissimum, pube albidâ subincanum.

CApUt. Maxille apice tridentatæ. Antenna nitidæ, nigræ, capite longiores.

Truncus. Thorax inermis. Scutellum rotundatum. Squamulc mạnæ, atræ, nitidissimæ. Ale fuscæ, latere exteriori nigræ. Pedes pilosuli, digitis articulis extimis obscure ferrugineis. Scopula fulvæ.

АвDOMEN arcuatum, subcylindricum, aterrimum, nitidum, albido-pilosulum, supra convexum, ano incurvo, rectangulo $(0)$. Venter planiusculus.

(o) Tab. 7.**. c. 1. $\beta$. fig. 6 . 
**. c. 2 . $\alpha$.

41. A. fulvescente-pubescens; abdomine brevi, Willughano nigro; antennis masculis articulo extimo liella. majori, manibus dilatato-ciliatis.

Apis sylvestris in arboribus putrescentibus cuniculos fodiens, ibidemque thecas cylindraceas recondens.

Rai. Hist. Ins. p. 245.

The IVillow Bee. Louth. alridg. of Phil. Trans.

Vol.2. c. 6. §. 17. n. 1-4.

Ray's Letters, p. 72-74.

Grew's Paritics, P. 1. §.7. c. 1. p. 154.

FIG. Schaeff. Fund. Ent. tal. 20. fig. 1.

MUS. D. Marsham, Trimmer, Haworth, Sowerly, Francillon, Kirby.

Long. Corp. Lin. $5 \frac{1}{2}-7 \frac{1}{2}$.

Hab. Barhamix. In Salicum putrescentium truncis centunculos e foliis convolutis struit.

DESCR. Acul.

CORPUS nigrum, pube fulvescenti.

CAPUT. Maxille validæ, forcipatæ, apice quadridentatæ, dentibus exterioribus duobus longioribus, acutis, interioribus truncatis $(p) . F a-$ cies ponè antennas pube fusco-nigricanti. Antennce nigræ, vix capite longiores.

TRUNCUs supra pube e fulvo rufescente mollis, translucente nigritudine corporis. Squamulce nigræ, pilosæ. Alce subhyalinæ, apice obscuriores, nervis crassioribus nigris, reliquis ferrugineis. Pedes fulvo-hirti, scopulis fuscis. Tibiarum Spinula ferruginex.

(p) Tab. 8. fig. 9 . 
A PIS. (**. c. $2, \alpha)$

ABDOMEN breve, subcordatum( () , anticè laruginoso-fulvum, posticè pilis atris hirtum, segmento penultimo et antepenultimo margine obscurè tomentoso-albidis. I'enter antice lanâ fulvo-aureâ, posticè atrâ, vestitus.

Var. $\beta$ dimidio minor.

Maris Corpus subtus villoso-incanum. Maxilla apicc acutè quadridentatæ, dentibus intermediis minoribus $(r)$. Antenna capite longiores, articulo extimo compresso, ancipiti, reliquis majori $(s)$. Facies ante antennas barbâ densâ pallidè flavâ, verticis villis fulvescentibus. Alce nervis nigris. Pedes pallido-hirti, scopulis fulvis. Femora antica flava, supra nigra, antrorsum lineolis duabus, longitudinalibus, nigris inscripta, lạnâ densâ fulvescenti subtus barbatæ. Tilice trigonæ, posticæ clavatæ, antic $x$ intus apiceque luteæ. Manus dilatatæ, albidæ, intus nigro reticulatx, extrorsum pilis longis admodum et densis, incurvisque ciliatæ $(t)$. Apophyses nigræ, primariæ articulo primo antrorsum mucronato $(u)$, secundo vittâ pallidâ picto. Al.lomen ex quadrato oblongum, ano inflexo cmarginato, lobis subserratis $(x)$. Venter planiusculus, segmento ultimo basi tridentato dentibus, nisi sub lente, vix conspicuis.

(q) Tab. 8. fig. 20. (r) Ibid. fig. 10. (s) Ibid. fig. 8. a. ( $t$ ) Ibid. fig. 28. $e, f, g$. (u) Ibid. c. \& fig. 27. $a a$.

$(x)$ Ibid. fig. 24. 
$V$ ar. $\beta$ corporis hirsutie cinerascenti.

$\gamma$ maxillis dente interiore truncato; femoribus anticis nigris, disco antrorsum pallido, immaculato; manibus intus tantùm puncto nigro notatis; tibiis anticis extrorsum apice pallidis.

Obs. In hâc varietate dentes ani ventrales conspicui magis quam in a et $\beta$.

I am led to give $A$. Willughliella as the Willow Bee, whose history and economy so attracted the attention of the English Naturalists of the last century, by the circumstance of its having been most commonly taken in places abounding with willow trees. I find it in Barham in some low meadows which are surrounded with them; it is also frequently met with at Brentford, and other places near the Thames

I have not hitherto been successful enough to meet with its nidus, so as to ascertain whether what I have given as the sexes come from the same, but they agree together in such particulars as the sexes usually do, and are found in the same situations, and therefore I feel no great doubt concerning their identity. Sir John Hill, in his translation of Swammerdam's Book of Nature, in a note, says, that he has seen thousands of the nests of these bees in Lincolnshire $(y)$; it is probable that where they so abound, they must do considerable injury to the trees in question.

(y) Hill's Swammerdam, P. 1. p. 227. Note*. 
A PIS. (**. c. 2. a.)

The male of $A$. Willughbiella is very like $A$. Lagopoda of Linneus, and is often mistaken for it ; but it is extremely distinct from the authentic specimen still preserved in the Linnean cabinet; the singular conformation of the tarsus of the fore feet, which is given as the most prominent characteristic of $A$. Lagopoda, is common, as I observed before $(z)$ to many distinct species, and is only a sexual character. This sex of our insect exhibits a peculiarity, which none of those that are related to it in the form of the anterior tarsus, possess, the last joint of its antennæ is larger than any of the rest, which gives them some resemblance to those of a Papilio (a), in A. Lagopoda, lidentata, and its other affinities, they are filiform. That this class of males may no longer be confounded with A. Lagopoda I shall insert in the margin a new description of that insect, taken from the authentio specimen $(b)$.

42. A.

(z) Vol. 1. p. 161.

(a) Tab. 8. fig. 8.

(b) lago- A. grisescente-pubescens; antennis masculis filiformibus; poda. tibiis posticis magnis clavatis, manibus dilatato-ciliatis.

Apis lagnpoda grisescens; pedibus anticis dilatato-ciliatis ; tibiis posticis clavatis ; ano emarginato.

Lin. Syst. Nat. Ed. 12. n.27. Fn. Suec. 1702.

Vill. Ent. Eur. 3. n. 22.

Fal. Ent. Syst. Em. n. 48.

Apis lagopus. Lin. Syst. Nat. Ed. Gmel.p. 2776, n.27.

MUS. D. Smith, Linnean.

Long, 
A PIS. (**. c. 2. $\alpha$.)

42. A. cinerascente-pubescens; abdomine femineo centuncusubcordato, segmentis margine albidis; mas- ${ }^{\text {laris. }}$ culo subgloboso.

Apis

Hab. In Sueciâ.

Long. Corp. Lin. $6 \frac{1}{2}$.

DESCR. Mas.

CORPUS nigrum pụbe pallidè grisescenti.

$\mathrm{C}_{\mathrm{APU}}$ magnum. Antenne filiformes. Facies barbâ densâ, pallidâ, tecta.

TRUncus supra pube griseâ, mollis, Squamulae rufæ. Ale subhyalinæ, apice paulo obscuriores, nervis nigris. Pedes hirti. Femora antica testacea. Manus dilatatæ, albæ, extrosum pilis densis, albis, incurvis, ciliatæ. Tilize ultimi paris magnæ, incrąssatæ.

AвDомen subrotundum, basi depressum, griseo-subhirsutum. Anus emarginatus lobis denticulatis.

I am not certain whether the mucro observable on the first joint of the anterior apophyses of the male of $A$. Willughbiella, exists in $A$. lagopoda or not; when the above description was drawn out, I had not observed it in the former, therefore it is very probable I might overlook it in the latter.

The insect which Schrank $(a)$ and Panzer $(b)$ have given as $A$. lagopoda is different from it, and likewise from $A . W i l$ lughbiella, but it appears to agree with an unlabelled specimen in the Linnean cabinet, which is placed with the former as a variety, but which is much smaller, not so hairy, with postefior tibiæ proportionably less. The figures of Sulzer $(c)$ and Christius $(d)$ bave no relation whatever to any of these males. I possess a foreign specimen of one, given me by the ingenious Mr. Sowerby, which exhibits the same peculiar structure of the anterior tarsus, and is extremely distinct from all the

(a) Enum. Ins. Austr. n. 810.

(b) Fn. Ins. Germ. Init. n. 55. tab. 7 .

(c) Tab. 27, fig. 17 .

(d) Tab. 9. fig. 3 .

others, 
Apis centuncularis nigra, ventre lanâ fulvâ.

Lin. Syst. Nat. Ed. 12. E Gmel. p. 2771. n. 4. Fn, Suec, $n .1687$.

Fal. Ent. Syst. Em. n. 98.

Vill. Ent. Eur. 3. n. 4.

Schrank. Enum. Ins. Austr. n. 815.

Fn. Frid. n. 844.

Mill. Zool. Dan. n. 1897.

Rossi. Fn Etrusc. 927

Apis nigra, abdomine supra lineis albis, subtus lanâ fulvâ.

Geofr. Hist. Ins. Par. 2, p. 410, n. 5.

Apis centuncularis. Fourcroy. Ent. Par. n. 5.

Forst. Cat. Brit. Ins. n. 708. Apis, n. 2.

others, as well as from the Andrena lidentata (e) of Fabricius, with which it has some affinity, this I shall now describe.

palmata. A. supra flavo-villosa; abdomine segmentis margine fulvescentibus, pedibus rufis, manibus masculis dilatato-ciliatis. MUS. Kirby.

Long. Corp. Lin. $4 \frac{2}{3}$.

Ubi habitat, nondum innotuit.

DESCR. Mas.

CORPUS nigrum, subtus villoso-canescens.

Capur. Antenna filiformes, thoracis ferè longitudine, nigræ, subtus ferrugineæ. Oculi magni, in mortuo, brunnei. Facies pube densâ fulvo-flavâ tecta.

Truncus supra villoso-fulvus. Squamula nigræ. Ale subhyalinæ, apice obscuriores, nervis piceis. Pedes ferrugineo-rufi. Tiliae anticæ crassæ, breves. Manus albæ, extrosum pilis densis, albis, incurvis, ciliatæ. Apophyses anticæ articulo primo antrorsum mucronato.

АвDомеN oblongum, segmentis margine tomentoso-fulvescentibus. Anus emarginatus. Venter subhirtus.

(e) Ent. Syst. Em, n, 27 . 


$$
\text { A PIS. (**. c. 2. «.) }
$$

FIG. Schaffer. Icon. tab. 262. fig. 6, 7 .

Reaum. Hist. Ins. 6. Mem. 4. tal. 10. fig. 2, 3, 4. \&c.

Baxin. Abregé. tal. 4. fig. 2. B.

Frisch. Ins. 2. p. 1. tal. 2.

Christii Hymenopt. p. 165. tab. 13. fig. 5.

Harris. Exp. tab. 49. fig. 2.

Barbut. Gen. Ins. tab: 15. Apis, fig. 9.

MUS. D. Marsham, $M^{c}$ Leay, Haworth, Sowerby, Trimmer, Francillon, Donovan, Lathbury, Kirly.

Long. Corp. Lin. 5-6.

Hal. Barhamiæ, tempore autunnali in Carduis obvia. In murorum cavitatibus et ligno putrescenti nidificat, centunculos ex rosarum et Mercurialis annua foliis struens. D. J. Trimmer.

DESCR. Acul.

CORPUS nigrum, pube cinerascenti.

CAPUT. Maxilla subforcipatæ, apice quadridentatæ, dentibus duobus exterioribus acutis, intermedio truncato, intimo emarginato $(a)$. Antennce capite vix longiores, nigræ.

Truncus. Thorax pube rarà admodum. Squamula nigræ. Alce subhyalinæ, apice obscuriores, nervis nigricantibus. Pedes hirti, tibiarum spinulis testaceis. Scopulce fulvoaureæ.

Ав DOMEN cordatum (b), villosulum, segmentis basi depressiusculis, utrinque piloso-albidis. Anus acutus. Venter lanâ densâ fulvo-aureấ vestitus.

Obs. Abdominis segmentum penultimum margine toto piloso-albido.

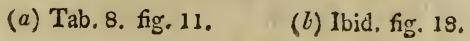


APIS. (**. c. 2, a.)

$V$ ar. $\beta$ corporis pube pallide flavescenti.

Maris Corpus flavescente densiùs villosum. $A n$ tennce capite longiores; nitidiusculæ. Maxilla apice bidentatæ, dente exteriori longiore, acuto, interiore magno, truncato $(c)$. Facics ante antennas barbâ densâ flavicanti tecta. Femora antica antrorsum apice sordidè flava. Abdomen ex oblongo subglobosum. Anus inflexus, subinteger, obsoletè denticulatus $(d)$. $V$ enter planiusculus, segmentis margine pilis albidis ciliatis:

This Apis is considerably smaller than the preceding, the abdomen of the aculeates is proportionally longer and narrower, and the margin of its dorsal segments is fringed on each side with white or yellowish hairs; the anus also has no black hairs. The male is still more strikingly distinguished from the same sex of $A$. Willughbiella, for it wants the dilated anterior tarsus, its antennæ are filiform, its maxillæ are armed at the apex with two tecth only, of which the interior is truncate and very short, its primary apophyses have no mucro upon their first joint, and its anus is entire.

The specimens labelled as $A$. centuncularis in the Linnean cabinet, do not agree with the description of that insect given in the Fauna Suecica. "Abdomen ovatum, nigrum, acutum, incisurarum marginibus albis." In those specimens the

(b) Tab, 8, figi, 12t (d) Ibid. fig. 26 ,

margin 
APIS. (**. c. 2. $\left.\alpha_{\text {. }}\right)$

margin of the abdominal segments has no white hairs, nor is the anus particularly acute, they appear to me to be the other sex of the genuine $A$. lagopoda. It is probable that Linneus, looking upon all the leaf cutter Bees as varieties only of the same species, was not particular in the selection of the specimens he preserved. Reaumur's figure and description agree with our insect, but those that he was acquainted with made their nests underground. Geoffroy represents his as nidificating in old wood, and the trunks of decayed trees. Mr. James Trimmer found the nest of ours in a decaying window-sell, and likewise in the cavity of a brick wall. He observed that this little bee made use of the leave's of Mercurialis annua, as well as those of the rose. Perhaps it is indifferent to this animal where she constructs her centunculi, provided it be in a place sufficiently sheltered from the weather. The insect which Scopoli took for A. centuncularis appears to me to be very distinct from it, he describes it as much smaller, and the thorax as covered with thick red hair $(e)$, a circumstance which will not at all agree with ours. The synonym of Ray $(f)$, which I have likewise excluded, evidently belongs to another insect, the terms " parva, corpore longo angusto," cannot well be looked upon as descriptive of $A$. centuncularis.

(e) Ent. Car. n. 799. Ann. Hist. Nat. 4. n..15.

(f) Hist. Ins. p. 242. n. 6.

Panzer's 
Panzer's figure $(g)$ has an oval obtuse abdomen; and I think belongs to an insect which I shall shortly describe.

maritima.43. A pallido-pubescens; thorace fusco; maxilliś magnis prominentibus; abdomine oblongo, segmentis margine albicantibus.

MUS. Kirly.

Long. Corp. Lin. 8.

Hal. In maritimis, prope Landguard fort in Suffolciâ semel lecta.

DESCR. Acul.

CORPUS nigrum, pube pallidâ.

CAPUT. Maxille prominentes, validissimæ, ferè conniventes, apice valde dilatatæ quadridentatæ, dente intimo truncato reliquis rotundatis $(h)$. Antenna nigræ, capitis longitudine. Oculi magni. Facies ante antennas barbà sordidè fulvâ tecta, pone antennas fuscescunt villi

Trunces supra fusco rariùs villosus, translucente nigritudine corporis. Squamulce piceæ. Ala subhyalinæ, apice paulò obscuriores, nervis piceis. Pedes hirti, tibiarum spinulis testaceis. Femora antica pallido barbata. Scopula fulvo-aureæ.

AвDomen ex ovato oblongum(i), segmentis anticis cinereo-subvillosis, basi depressis, posticis tribus margine piloso-pallidis. Anus ob(g) Fn. Ins. Germ. Init. в. 55. tab. 12.
(h) Tab. 8. fig. 13 .
(i) Ibid. fig. 19

tusiusculus. 
tusiusculus. Venter anticè lanâ fulvâ, posticè fuscâ, tectus.

This insect is distinguished, from those that precede it, by the size of its maxillæ, which are unusually large and prominent, and scarcely, if at all, forcipate; the teeth at their tips are most of them rounded, none being acute, as in the others; the abdomen, also, is of a different shape. Panzer has figured a maxilla as belonging to the other sex of his $A$. centuncularis $(k)$, which represents well the same part of $A$. maritima. It is certainly not the maxilla of a male, and his figure is that of an aculeate, whence it follows that it belongs to another species.

44. A. griseo-pubescens; abdomine femineo sub-ligniseca. ovali; masculo subgloboso, ano emarginato.

FIG.

ACUL.

Apis centuncalaris. Panzer. Fn. Ins, Germ. Init, n.55., tab. 12.

Donovan. Eng. Ins. 4. tab. 120,

MAS.

Tab. 16. fig. 11.

MUS. D. Marsham, Donovan, Kirby.

Long. Corp. Lin. 7-8.

Hal. Barhamiæ. Centunculos ex ulmorum et rosarum foliis convolvit, in arborum putrescentium truncis nidificans,

(k) Fn. Ins. Germ. Init. n. 55, tab. 12. fig. a.

VOL. II.

DESCR. 
DESCR. Acul.

CORPUS nigrum, pube grisescenti.

CAput. Maxilla prominentes, validæ, forcipatæ, apice quadridentatæ, dentibus exterioribus duobus acutis, intermedio truncato, intimo emarginato $(l)$. Antennce capitis ferè longitudine, nigræ.

TRUnCus supra villis sordidè fulvis tecta, disci pube rariore nigricanti, Squamule nigræ. Al.e subhyalinæ, apice obscuriores, nervis nigris. Pedes hirti, tibiarum spinulis ferrugineis. Scopulce fulvo-aureæ.

Ав дом́⿱一⿻上丨丨八 ex oblongo ovale $(m)$, anticè cinereosubvillosum, posticè pilis nigris consitum. Anus obtusiusculus. Venter lanâ fulvâ vestitus.

Var. $\beta$ ventris lanâ, anum versus, nigrâ.

Maris Corpus longiùs et densiùs villosum. Facies ante antennas barbà densâ flavescenti. $A n$ tennie thorace breviores. Thorax pube fulvescenti. Aldomen ex oblongo globosum, flavescenti vellere lanuginosum, ano inflexo, emarginato $(n)$.

Var. $\beta$ corporis hirsutie cinerascenti; digitis articulo extimo ferrugineo.

This insect has been figured as $A$. centuncularis by Panzer and the ingenious Mr. Donovan, it is, however, very distinct from it; for it is not only

(l) Tab. s. fig. 14. (m) Ibid. fig. 21.

(n) Ibid, fig. 25. considerably 
APIS. (**. c. 2. a.)

considerably larger, but the abdomen of the aculeates instead of being cordate is oval, and its dorsal segments have no white marginal fringe. The anus also of the males is emarginate. The last mentioned author informs us that $A$. ligniseca commits great ravages in oak plantations; trees of that kind, apparently healthy, at Birdbrook in Essex, being completely perforated by it, and filled with its centunculi: but it does not confine itself solely to the oak, for upon the tenth of September; 1799, upon observing a bee belonging to the present subdivision enter the trunk of a putrescent elm, I obtained leave to take the tree down; upon opening it, I discovered, in the center, the nest, and also one of the bees, which proved to be the one now before us. The nest was made of elm leaves, each cell was about an inch and a quarter in length, and not quite half an inch in diameter ; a circumstance which furnishes an additional proof that this insect is distinct from $A$. centuncularis, for the cells of the latter are not an inch in length, and scarcely the fourth of an inch in dianeter. The tree which $A$. ligniseca had selected to contain her nest, was beginning to decay at the heart, here she had bored a channel whose diameter was adapted to that necessary for her cells, the direction of which was according to the state of the wood at the center, following the putrescent vein, Plot, in his history of Staffordshire, makes mention. of one of these bees as constructing its nest in a decaying crab tree. 
circum- 45. . lanuginoso-flava; capite, anoque, atris. cincta. FIG. Tal. 16. fig. 10.

MUS, Kirly.

\section{Long. Corp. Lin. $6 \frac{1}{2}$.}

Hab. In Cantio, apud Dartfordiam in aggere aprico a D. Goodenough semel lecta.

DESCR. Acul.

CORPUS atrum, lanugine densâ, fulvo-flava, vestitum.

CAput. Maxille prominentes, validæ, apice quadridentatæ, dentibus æqualibus, rotundatis, intimo truncato $(o)$. Facies atro-villosa. Antennce capitis longitudine, subclavatæ.

Truncus supra lanugine fulvo-flavâ tectus, translucente nigritudine disci. Squamulce nigre. Alce hyalinx, nervis nigris. Pedes flavescente-pilosi. Spirrulu' furruginex. Plante intermedire extus hirtæ. Scopulae densæ, fulvæ.

Aвромex subglobosum, dimidio antico lanugine fulvo hirsuto, postico atro piloso. Venter lanâ fulvâ tectus, ano atro.

xanthomelona.

46. A. aterrima, villosa; thorace, abdominisque basi, lanuginoso-flarescentibus.

Apis nigra, thorace, abdominisque basi supernè lanà ruf.̀.

Geofir. Hist. Ins. Par. 2. p. 409. n. 4 ?

Apis parietina. Fourcroy. Ent. Par. n, 4?

MIUS, Kïrly.

(o) Tab. 8. fig. 15. 
A P IS. (**. c. 2, «.)

Long. Corp. Lin. 6.

Hal. In Suffolciâ. Apud Somersham prope Ipswich, in aggere aprico argillaceo, Julio ineunti 1798, semel capta.

DESCR. Acul.

CORPUS aterrimum, villosum.

Caput. Maxille validæe, subforcipatre, apice quadridentatæ dentibus rotundatis extimo acutiusculo $(p)$. Antennce capitis longitudine, subclavatæ.

Truncus supra lanugine flavescenti vestitus. Squamule nigræ. Alce fusco-ncbulosæ, nervis piceis. Pedes hirti. Digiti articulo extimo piceo.

А в оомем subglobosum, supra convexum, basi lanuginoso-flavescens, ano piloso atro. Fenter lanâ atrâ.

This insect departs somewhat from the general habit of this subdivision, the upper side of the abdomen being convex, instead of flat; it seems to approach very near to Geoffroy"s "Abeille maçonne à poils roux;" but as he describes his as having tawny hairs upon its head and legs, which is not the case with ours, I have added a mark of interrogation to his synonym. My specimen, the only one I ever saw, I taok creeping upon a clay. bank of a southern aspect, not in the neighbourhood of any wall.

(1) Tab. 8. fig. 16 .

R 3

**. c. 
**. c. 2 . $\beta$.

- manicata.47. A. albido-villosa; abdomine maculis flavis lateralibus; ano masculo inflexo, quinquedentato.

Apis manicala nigra, pedibus anticis hirsutissimis, ab. domine maculis flavis lateralibus, ano tridentato.

Lin. Syst. Nat. Ed. 12, n.28. Fn. Suec, 1701.

Vill. Ent. Eur. 3. n. 23.

Ross. Fn. Etrusc. n. 914.

Forst. Cat. Brit. Ins. n. 717. Apis, n. 11.

Berkenhout. Synops. 1. p. 159. n. 4.

Apis manicata cinerea, abdomine nigro, maculis flavis lateralibus, ano quinquedentato.

Fab. Ent. Syst. Em. n. 73.

Lin. Syst. Nat. Ed. Gmel. p. 2777. n. 28.

Apis abdomine fasciis flavis interruptis, apice spinâ quintuplici flavâ armato.

Geoffr. Hist. Ins. Par. 2. p. 40s. n. 3.

Apis manicata. Fourçroy. Eut. Par. n. 3.

Apis sylvestris, abdomine lato nigricanti; ad pronæ et supinæ partis commissuram lanugine rufa vel albiఛ cante donata.

Rai. Hist. Ins. p. 242. n. 1.

FIG. Swammerdam. Bibl. Nat. tab. 26. fig. 4.

Schaffier. Icon. tab. 32. fig. 11, 12. Opuscula, tab. 40. fig. 66.

Christii Hymenopt. p. 133. tal. 9. fig. 5. mal.

Harris, Exp. Eng. Ins, tab. 49. fig. 3.

Panzer. Fn. Ins. Germ. Init. n. 55. tab. 11.

Tab. 16. fig. 12. Acul. fig. 13. Mas.

MUS. D. Marsham, Latham, Hawarth, Francillon, Trim: mer, Lathlury, Kirby.

Long. Corp. Lin. $5 \frac{1}{2}-8 \frac{1}{2}$.

Hab. In hortis oppidanis in Suffolciâ frequens, tomentum e foliis, præcipuè Stachyos lanata, et Agros. 
A P I S. (**. c. 2. $\beta$.)

temmatis coronaria, (quocum cellulas et nidum suum obvolvit) maxillis abradens.

\section{DESCR. Acul.}

CORPUS nigrum, subtus villoso-albescens.

CAPUT. Maxilla flavæ, apice nigræ, multiden$\operatorname{tatæ}(q)$ dentibus intermediis minoribus, $F a$ cies cinerascente-pubescens, anticè utrinque flava. Nasus apice denticulatus. Occiput utrinque puncto flavo notatum.

Truncus supra pube griseâ mollis, translucente nigritudine corporis. Squamulce nigræ, anticè villosæ, puncto flavo notatæ. Metathorax utrinque villoso-albus. Alce fuscescentes nervis nigris. Pedes flavescente-pilosi, femoribus quatuor posticis dimidiato-rufis. Tibice basi maculâ flavâ, anticæ insuper lineâ flavâ longitudinali inscriptæ, posticæ intus certo situ tomentoso-pallidæ. Plante extrorsum tomento densissimo albido molles, intermediis majoribus. Scopula ferrugineæ.

А в домen supra subvillosum, punctulatum, segmentis utrinque puncto flavo notatis. Segmentum antepenultimum punctis flavis quatuor. Abdominis latera flavo-ciliata. Anus obsoletè trilobus, incurvus. Venter lanâ pallidâ tectus.

$V a r . \beta$ occipite punctis flavis nullis; tibiis anticis basi apiceque flavis; abdomine seg-

(q) Tab. 9. 2. ß. fig. 6. 
A P IS. $(* *, c, 2, \beta$. $)$

mento antepenultimo maculis tantùm duabus mediis flavis.

Maris Maxille apice tridentatx( $r)$. Facies ante antennas flava maculâ posticâ mediâ nigrâ. Pedes albido-hirti. Femora nigra, apice subtus dente obtuso utrinque instructa. Tilia quatuor anteriores apice flavæ, cunctæ subtus barbâ densâ albâ. Plantå albo hirsutissinæe. Palma flavæ. Apophyses posticæ articulo secundo intus obtusangulo $(s)$. Aldomen ciliâ densâ, incurvâ, pallidâ utrinque ornatum, segmento penultimo maculis duabus sublunatis, flavis picto, utrinque spinâ incurvâ armato $(t)$, ultimo spinis tribus incurvis instructo, intermedio recto breviori, lateralibus divaricatis $(u)$. Anus sxpe valde inflexus.

Obs. Aldominis segmenta intermedia in angulum f. dentem obtusum protensa $(x)$. Plante interdum flave.

Linneus in his definition of this insect seems to have overlooked the spines which arm the last segment but one of the abdomen of the male; for instead of being tridentate the anus is in fact quinquedentate. This error has been rectified by Fabricius. The synonym of Swammerdam evidently belongs to $A$. manicata, and not to $A$. quadridentata, for the dorsal spots of the abdomen, and five

(r) Tab. 9. 2. B. fig. 7.

(t) Ibid. fig. 11. $6 t$.

(s) Ibid. fig. 12. $b$.

(u) Ibid, $c$.

(x) Ibid. $a$. 
A PIS. $(* *$. c. 2. $\beta, \gamma$.)

spines of the anus, are plainly represented in his figure. Geoffroy has mistaken the male for the female, and Panzer has fallen into the same error, that which he has given as the male is a distinct species. Anal spines or teeth in this family are invariably a sexual distinction, and point out the males.

\section{**. c. 2. $\gamma$ 。}

48. A. atra, supra glabriuscula; maxillis promi-maxillosa nentibus, intus barbatis; abdomine segmentis margine albis.

Apis maxillosa nigra, maxillis prominentibus, antennis

thorace brevioribus, abdomine cylindrico subtus luteo

hirsuto.

Lin. Syst. Nat. Ed. 12. छ Gmel. p. 2773. n. 11.

Vill. Ent. Eur. 3. n. 10.

Hylaus maxillosus, Fal. Ent. Syst. Em. n. 4.

FIG. Panzer. Fn. Ins. Germ. Init. n. 53. tal. 17.

MUS. D. Marsham, Latham, Hawortin, Trimmer, Lathbury, Francillon, Kïly.

Long. Corp. Lin. $4-5 \frac{1}{2}$.

Hal. Barhamiæ, in floribus haud rara. In paxillis nidificat et lignis siccis Ichneumonibus munifestatori jaculatori et femoratori $\mathrm{K}$, abnoxia.

DESCR. Acul.

CORPUS atrum, pube, rarâ admodum, albidâ consitum.

CAPUT. Maxille arcuatæ, prominentes, forcipatæ, ferè capitis longitudine, apice bidentatæ dente exteriori longiore, intus fulvescentebarbatæ, 
barbatæ $(y)$. Labium valde elongatum, rostrum ferè totum obtegens (z). Nasus apice squamâ a capite extante instructus. Antenna clavatæ capitis longitudine $(a)$. Vertex calvus. Oculi posticè attenuati.

Truncus obovatus. Squamula nigræ. Ala paululùm infuscatæ, apice nervisque nigris. Pedes pallido-hirti. Scopulce fulvæ.

АвDOMEN cylindricum, nitidum, punctulatum, segmentis margine piloso-albis. Venter lanâ densâ, pallidè luteâ tectus.

This singular insect may always be known by its prominent maxillæ, which when closed leave a space between themselves and the mouth, which space is filled by the hairs with which their inner side is bearded; its lip is also remarkably elongate. Panzer has given an admirable figure of it; that of Christius belongs to some other insect. We learn from Mr. Marsham that A. maxillosa is the prey of Ichneumon manifestator, and from Bergman that 1 . jaculator pierces this as well as $A$. fiorisomnis, which indeed I strongly suspect to be its male. Nor are these the only insects of that genus to the attacks of which our Apis is exposed, for Mr. J. Trimmer has taken another out of its foramina, which, as it appears to be a non-descript, and
(y) Tab. 9. 2. $\gamma$. fig. 6.
(z) Ibid. fig. 2. b.

(a) Ibid. fig. 7. 
A P I S. (**. c. 2. $\gamma$. $)$

may easily be confounded with 1 . comitator, $I$ shall describe below $(a)$.

49. A. atra, cinereo-villosa ; abdomine masculo in-florisom 4 . curvo, ventre basi cornuto, ano obtusè biden- ${ }^{\text {nis. }}$ tato.

Apis florisomnis nigra, abdomine subcylindrico incuryo, ano bidentato, tibiis posticis apice spinosis.

Lin. Syst. Nat. Ed. 12. n. 13. Fn. Suec. 1704.

Vill. Ent. Eur. 3. n. 12 ,

Scop. Ent. Car. n. 796.

Miill. Zool. Dan.n. 1903.

Forst. Cat. Brit. Ins, n.711. Apis, n.5.

Hyleus florisomnis abdomine subcylindrico incurvo ano bidentato.

Fab. Ent. Syst. Em. n. 5.

Lin. Syst. Nat. ed. Gmel. p. 2773. Apis, n. 13.

FIG. Harris. Exp. Eng. Ins. tab. 50. fig. 11.

Hylaus florisomnis. Panzer, Fn. Ins, Germ. Init n. 46. tab. 13.

Ichneumon. ***.

(a) I. ater; antennis thoracis longitudine fasciâ albâ; femoribus femora piceis.

Totus ater exceptis femoribus posticis piceis. Antennæ hinc tantùm fasciâ mediâ albidâ.

Obs. I. comitatore triplo minor, cui simillimus. Differt tamen non solùm antennis vix thorace longioribus, et femorilus piceis, verùm etiam alis hyalinis nervis nigricantibus, cum in illo obscurce f. subtestacee sint ale, nervis ferrugineis. Femora item crassiora et lreviora in hoc quam in illo. Unde character I. comitatoris meliùs sic exprimeretur.

I. ater, antennis corporis longitudine fasciâ albâ.

comitator. MUS, 


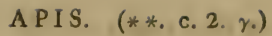

MUS. D. Smith Linnean, Marsham, Latham, Francillon, Lathlury, Trimmer, Kirly.

Long. Corp. Lin. 4-5.

$\mathrm{Hal}$. Barhamiæ, in floribus tempore vernali baud rara, In floribus pernoctat. Lin.

DESCR. Mas.

CORPUS atrum, cinereo-villosum.

CAPUt. Maxille apice bidentatæ dentibus acu= tis. Gence apud basin maxillarum in dentem obtusum protensæ. Facies ante antennas densiùs barbata. Antennce filiformes, capite longiores, hinc subdentatæ $\int$. articulis subtus medio obtusangulis $(b)$.

Truncus subovatus, villosus. Squamula nigræ. Ala infuscatæ, apice nervisque nigris. Pedes hirti, spinulis testaceis. Scopulc fulvæ.

AвDOMEN semicylindricum, punctulatissimum, segmento ultimo bidentato, dentibus obliquè truncatis $(c)$. I'enter anticè cornu brevi, crasso, supra concavo, apice rotundato armatus $(d)$; cui e regione opponitur cavitas tomentoso-pallida (e), segmento ultimo recurvo, apice bidentato $(f)$.

No insect, in this genus, that I am at present acquainted with, exhibits so many singularities of form as A.forisomnis. The tooth in which its genæ terminate, the intermediate joints of its an-

(b) Tab. 9. 2. $\gamma$. fig. 9 .

(c) Ibid. fig. 12. $a a$.

(d) Ibid. fig. 11. $a$.

(e) Ibid. $d$.

(f) Ibid, c. \& fig. 12, $b l$.

tenna 


$$
\text { APIS. (**. c. 2. \%.) }
$$

tennæ jutting out on their under side into an obtuse angle, the remarkable horn or protuberance which arms the base of the venter, the cavity which answers to it, and into which, when the insect reposes in its flowery bed, it is probably inserted, and the teeth which terminate its anus on the underside, are peculiarities, which I do not recollect that any preceding author has noticed, but which strikingly distinguish this insect. All of these however I take to be sexual distinctions, for this insect is always male and the preceding is as invariably of the other sex, a circumstance, which, combined with general traits of resemblance, makes me suspect that they are only the sexes of the same species. The spines at the apex of the tibir, which Linneus has introduced into his definition, are not more conspicuous in this, than in the other species of the genus; Fabricius has therefore very properly omitted them in his character.

Schæffer has written a monograph in German upon an Apis, which he calls $A$. florisomnis $(g)$, but which is, in fact, a very different species. He describes it as distinguished by a very particular circumstance, namely, antennæ involute or turned in at their tips. His figure represents an insect quite distinct from ours, it may possibly, be the

(g) Abhandl. von Insecten. 3. Band. p. 125-30. tab. 1-5. fion, tab. 32, fig. 9, 10 .

Eucera 
Eucera curvicornis of $\operatorname{Scopoli}(h)$, of which that author says, "Antennarum apices adeo intorti ut capitulum referant." Schæffer seems to have been led into this mistake by finding his insect in the bell of a flower. Christius has given a figure for A. florisomnis which has no-relation whatever to it (i); Panzer's is excellent.

- Campa 50. A. atra, glabriuscula; ano masculo inflexo, nularum. acutè bidentato, ventre basi gibbo.

FIG. Apis forisomnis minima. Christii Hymenopt. p. 197. tal. 17. fig. 8.

Tab. 16. fig. 14. Acul. fig. 15. Mas.

MUS. D. Marsham, Haworth, Latham, McLeay, Trimmer, Sowerby, Lathbury, Kirby.

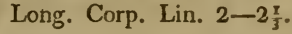

Hal. Barhamiæ. In floribus Campanularum frequens, in quibus mas sæpe pernoctat.

DESCR. Acul.

CORPUS atrum, glabriusculum, punctulatissimum.

Caput. Nasus gibbus. Antenna nigræ, capitis vix longitudine.

Truncus. Squamula piceo-nigræ. Ala paulò infuscatæ, subiricolores, nervis nigris. Pedes cinereo-pilosuli, scopulis fulvescentibus. $S p i$ nula testaceæ.

Aв Domen cylindricum, ano obtusiusculo. $V e n$ ter lanâ haud densâ lutescenti.

(h) Ann. Hist. Nat. 4. p. 9. n. 3.

(i) Hymenopt. p.172, tab. 13. fig. 11. 
A PIS. (**. c. 2. \%.)

Maris Corpus cinereo-villosulum. Antennce filiformes, capite longiores $(k)$. Facies ante antennas niveo-villosula. Abdomen inflexum ano acutè bidentato $(l)$. Venter segmento secundo tuberculo elevatiusculo munito $(m)$, cui ex adverso opponitur apud anum cavitas rotunda, tomentoso-pallida.

This little Apis, by far the most minute species of this genus, that I have yet seen, is common, during the summer and autumnal months, in the blossoms of Campanula Trachelium, rotundifolia, and hybrida, and, what deserves to be remarked, I never found it in the flowers of any other genus of plants. The males are often taken asleep in these flowers, their abdomen is then doubled, so that the tubercle, with which its base is armed, fits into the cavity near the anus. The aculeates partake of the habit of $A$. maxillosa, and the males in the same degree resemble $A$. florisomnis, a further proof of the identity of those insects. I have never met with this insect in any other situation than the above, and therefore I can say nothing further with respect to their mode of nidification, than that it is most probable that, with the other species of this subdivision, they make their cells in posts, rails, and the like. The male of $A$. campanularum is, I think beyond a doubt, the $A$. florisomnis minima of Christius.

(k) Tab. 9. 2. \%. fig. 8.

(l) Ibid. fig. 14.

(m) Ibid. fig. 13. $a$,

51. A. 
- trunco- 51. A. atra; abdominis basi transversè carinato; ruin. segmentis margine albidis; ano masculo inflexo, inermi.

Apis truncorum nigra, glabra, fronte albidâ, pubescente, abdomine segmentis margine albidis, subtus flavicante.

Lin. Syst. Nat. Ed. 12. E Gmel. p. 2773. n. 12. Fn。 Suec, n. 1692.

Vill. Ent. Eur. 3. n. 11.

Miill. Zool. Dan. n. 1900.

Hylceus truncorum niger, abdomine cylindrico, seg. mentis margine albis, subtus cinereo hirsuto.

Fal. Ent. Syst. Em. n. 9 ?

FIG. Hyleus truncorum. Panzer. Fn. Ins. Germ. Init. n. 64. tab. 15.

MUS. Regina Acul(n), D. Smith Linnean Acul, Haw orth Mas, Kirly Acul, Mas.

Long. Corp. Lin. $2 \frac{x}{2}-4$.

$H a l$. Brentfordiæe, et alibi prope Londinum, sed rarissima, femina semel lecta a D. J. Trimmer, mas bis a D. Haworth.

DESCR. Acul.

CORPUS atrum, punctulatissimum, albidosubvillosum.

CAPUt. Maxilla forcipatæ, apice bidentatæ dentibus acutis, supra subcarinatæ, $\int$. lineâ longitudinali elevatiusculâ notandæ. Antennce nigr $x$, subfiliformes, capite longiores. Facies ante antennas albido densiùs barbata. Gena

' (n) I saw this in her Majesties collection, in the Observatory in Richmond gardens; it was the ninth specimen from the left hand, in the first row, at the end of the drawer. 
subtus utrinque mucrone, $f$. dente brevi, postico, armatæ.

Truncus. Squamulce atræ. Alce fuscescentes, apice obscuriores, nervis nigris. Pedes pilosuli, spinulis scopulisque fulvis.

Ав домen cylindricum, basi retusum, segmento primo supra transversè carinato, $\int$. lineâ arcuatâ, transversâ, elevatiusculâ notato. Segmenta omnia margine pilis densis, brevibus, niveis ciliata. Anus subincurvus, pilis decumbentibus, pallidis canescens. Venter lanâ, densâ admodum, flavescenti vestitus.

Maris Corpus minus. Gence inermes. Maxille supra haud carinatæ. Abdomen segmentis anticis margine albicantibus. Anus inflexus, segmento ultimo integro, subcompresso, utrinque foveolâ transversâ excavato. Venter basi niveo-villosus, convexus, apice cavitate satis profundâ ingignis:

Two or three distinct insects are placed together, in the Linnean cabinet, as $A$. truncorum, the one I have just described is the same with the labelled specimen. Linneus says, in his Fauna Suecica, "Antennce longitudine thoracis. Aldominis segmenta vix margine albâ, sed potiùs versus latera." But in the above specimen, and our English one, the antennæ are only a little longer than the head, and the whole margin of the abdominal segments is fringed with white hairs; this description was probably made from one, part of whose hairs had 
A PIS. (**. c. 2. \%. ठ.)

been rubbed off, an accident to which these animals are very subject. Christius has given an A. truncorum, but it is a very different insect. Panzer's figure is tolerably accurate, he has made the tip of the wings rather too dark. The synonym of Fabricius seems to me rather dubious, for he says of his "abdomine--subtus cinereo-hirsuto," which is not the case with $A$. truncorum; in a specimen long disclosed, however, the hairs on the underside of the abdomen might turn to cinereous; and Panzer observes upon this species "variat abdominis lanâ subtus cinereâ et flavâ.”

$$
\text { **. c. } 2 . \delta \text {. }
$$

lincome- 52. A. aterrima, albido-subvillosa; abdomine seglana. mentis margine utrinque albis, ventre laná cinerascenti.

MUS. Kirly.

Long. Corp. Lin. $3 \frac{3}{4}$.

IIal. Coddenhamiæ prope Needham Market in Suffolciâ, a me in pineto quodam tempore autumnali in floribus Leontodontis semel lecta.

DESCR. Acul.

CORPUS aterrimum, nitidum, levissimè punctulatum, pube albescenti subincanum.

Caput. Maxilla apice tridentatæ. Antenne subclavatæ, capitis longitudine, nigræ, apice subtus nigro-piceo.

Truncus posticè satis villosus. Squamula aterrimæ, nitidæ. Alc infuscatæ, nervis nigris. 
Pedes hirti, tibiarum spinulis nigris. Scopule cinereæ.

AвDомEir ex ovali sublineare, supra glabriusculum, segmentis anticis quatuor margine utrinque pilis niveis ciliatis, primo et secundo apice auctis. Venter lanâ haud densâ cinereâa mollis.

This species, although very distinct from it, is very liable, at first sight, to be confounded with A. truncorum. If its proboscis be not unfolded, so that the palpi can be examined, it may always be known by the absence of the elevated curved line, which is observable upon the first segment of the abdomen of both sexes of the latter insect. It may possibly be the Hylaus truncorum of Falricius. I look upon this insect as forming the connecting link which unites the present with the preceding subdivision.

53. A. atra, cinereo-subvillosa; scutello bidentato ;spimalosa. ano masculo inflexo, spinuloso, ventre basi cornuto.

FIG. Tab. 17. fig. 1. Acul. fig. 2. Mas.

MUS. D. Marsham, Trimmer, Lathbury, Sowerly, Kirby. Long. Corp. Lin. 3-4.

Hal. Apud Witnesham et Blakenham Parvanı prope Gippovicum in Suffolciâ, in arenariis et cretariis tempore autumnali haud rara,

DESCR. Acul.

CORPUS atrum, punctulatissimum, cinereo. villosum. 
CAPUT. Maxille apice tridentatæ, dentibus acutis. Antenne nigra, subclavatæ, capitis longitudine. Oculi, in vivo, chrystallinocæsii, fundo favoso. Facies inter antennas hirsutie flavescenti.

Truncus supra pube grisescenti. Scutellum dente parro, acuto, sub hirsutie ocultato et vix sine tactu dignoscendo, utrinque armatum. Squamulı atræ. Alce paulò infuscatæ, apice obscuriores, nervis nigris. Pedes grisescentehirti. Tilia posticæ apice tomentoso-fulvescentes. Scopulce fulvæ. Spinula testaceæ. Digiti picei.

Ав оомеy subglobosum, nitidum, punctulatissimum, supra glabrum, segmentis anticis margine interruptè, posticis continuè, piloso-albicantibus. Anus subdeclivis. Venter lanâ densâ, forrugineâ tectus.

Maris Maxilla apice bidentatæ. Facies ante antennas vellere denso flavescenti tecta. $A n-$ tennce filiformes capite longiores. Alce dilutiores. Anus dentato-spinulosus (o). Venter cinereo-subvillosus, apud basin et apicem cornu erecto, acuto, armatus.

This little Apis, the male especially, exhibits many peculiar characters; the anus fringed, as it were, with minute spines, and the remarkable horn, which, if it be closely examined, will be discovered

(o) Tab, 10, **, c, 2, \&, fig. 18. 
upon the first and last ventral segment of the abdomen, sufficiently distinguish it from every other species with which I am, at present, acquainted. In the autumn of the year 1797 I found it, in tolerable plenty, in sand and chalk pits; since which time I do not recollect to have observed it.

54. A. atra, griseo-villosa; abdomine nitido, atro-Leaiana. cærulescenti, ventre lanâ ferrugineâ.

Apis nigra, hirsutie flavâ, abdomine supra glabro, nitente, cupreo.

Geoffr. Hist. Ins, Par. 2. p. 411, n. 6.

Apis hirta. Fourcroy. Ent. Par, n. 6.

MUS. D. McLeay, Marsham, Latham, Sowerly, Lathbury, Trimmer, Kirby.

$$
\text { Long. Corp. Lin. } 3 \frac{1}{2}-5 \text {. }
$$

Hal. Barhamiæ, in Carduis tempore autumnali haud rara.

DESCR. Acul.

CORPUS atrum, punctulatissimum, pube grisescenti.

CAPUT magnum. Maxille vix forcipatæ, apice tridentatæ, dente interiori truncato, exterioribus duobus acutis, disco supra tomento aureo tecto. Antennce nigræ, capitis longitudine. Facies satis hirta.

Truncus. Squamule nigræ. Alæ fuscæ, albido subnebulosæ, nervis nigris. Pedes rufescente-pilosi. Scopulce ferrugineæ. Spinule nigræ.

AвDOMEN ex oblongo cordatum, atro-cærulescens, basi subretusum, supra subglabrum, nitidissimum. 
nitidissimum. Pili rufi, haud densi, segmen torum margines, anticorum interruptè, fimbriant. Anus incurvus, rufo-subtomentosus. Venter lanâ densâ ferrugineâ tectus. $V$ ar. $\beta$ dimidio minor; abdomine nigro-æneo. $\gamma$ corporis hirsutic cinereâ ; abdomine aterrimo, segmentis margine derasis. An eadem?

In honorem D. A. Mac Leay, Soc. Linnæan. a Secretis, viri amicissimi, Natura regna, et imprimis Entomologiam, summo judicio et acumine perlustrantis, hoc insecium nominavi.

This insect agrees tolerably well with Geoffroy's description of his "Abeille fauve à ventre cuivreux," except that the hair of the body can scarcely be called red. Since both Fabricius and Schrank have an Apis hirta, I have altered Fourcroy's trivial name. Variety $\gamma$ may, perhaps, be a distinct species; but upon the whole it so strongly resembles $\alpha$, that I have not ventured to separate them.

55. A. corpore femineo atro, albido-subpubescens; abdomine cærulescenti, segmentis margine

- albicantibus, ventre lanâ atrâ :

corpore masculo æneo, fulvo-pubescente; ano bidentato.

\section{ACUL.}

Apis carulescens fusca, subvillosa; abdomine cærulescente, incisurarum marginibus albicantibus.

Lin. Syst. Nat. Ed. 12. E Gmel. p. 2793. n.21. Fn, Suec, n. 1696.

Vill. Ent. Eur. 3. n. 17.

Miill. Zool. Dan. n. 1902. 
Ross. Fn. Etrusc. n. 893.

Forst. Cat. Brit. Ins. n.714. Apis, n.8.

Andrena cærulescens. Fal. Ent. Syst. Em, n. 1.

EIG. Harris. Exp. Eng, Ins. tab.49. fig. 10.

Andrena cærulescens. Panzer. Fn. Ins. Germ. Init. n. 65. tab. 18.

Abeille maçonne, dont la femelle est d'un bleu violet à poils cendrés, et le mâle d'un verd bronzé luisant à poils roux.

De Geer. 2. ptie. 2. p.751-4. tal. 30. fig. 23.

MUS. D. Smith Linnean, Marsham, Haworth, Trimmer,

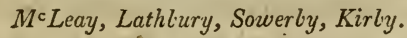

\section{MAS.}

Apis anea ænea, grisescente-pubescens.

Lin. Syst. Nat. Ed. 12. छ Gmel. p. 2793. n. 20. Fn. Suec. $n .1695$.

Vill. Ent. Eur. 3. n. 16.

Scop. Ent. Car. n. 809.

Ross. Fn. Etrusc. n. 894.

Andrena anea. Fab. Ent. Syst. Em. n.8.

FIG. Panzer. Fn. Ins. Germ. Init, n. 56. tab. 3.

De Geer. ubi supra, et tab.32. fig. 1.

MUS, D. Smith Linnean, Marsham, $M^{\mathrm{c}}$ Leay, Haworth, Latham, Sowerby, Francillon, Trimmer, Lathbury, Kirby.

Long. Corp. Lin. $3 \frac{3}{4}-4 \frac{x}{3}$.

$H a b$. Barhamiæ et alibi. In murorum cavitatibus et angulis nidificat, cellulas ex arenâ et argillâ conficiens. Larvæ in pupam conversuræ folliculum nent sericeum. De Geer. Mas feminâ frequentior, circa muros et palos antiquos tempore æstivo volitans: serior femina provenit, in cretariis interdum obvia.

DESCR. Acul.

CORPUS atrum, obscurum, punctulatissimum, pube albicanti incanum. 
A PIS. (**. c. 2. 8.)

Caput trunco majus. Maxille validæ, apice obtusè tridentatæ, dente interiori obsoletiusculo, supra pilosx, lineis duabus elevatis notatæ. Antenna vix capitis longitudine, filiformes, piceo-nigræ.

Truncus. Squamule picex. Alce infuscatæ, albido nebulosæ, nervis nigris. Pedes albidohirti. Scopulce fuscæ.

Ав домеN subglobosum, cærulescens, nitidiusculum, segmentis, posticis præcipuè, pilis albis ciliatis. Venter lanâ atrâ, haud densâ, tectus. $V$ ar. $\beta$ minor, corpore toto violaceo; alis hyalinis, apice nigris.

Maris Corpus xneum, grisescente-pubescens. Maxille apice bidentatæ. Antennce tenues, vix thorace breviores. Truncus supra hirsutofulvus. Alce subhyalinæ, apice fuscescentes, nervis piceis. Pedes fulvo-hirti, scopulis fulvis. Aldomen fulvo-subvillosum, segmentis margine fulvo ciliatis. Anus incurvus, emarginatus. Venter segmento ultimo bidentato $(p)$. Var. $\beta$ major, viridi-æneus; corporis toti hirsutie cinerascenti; alis infuscatis, albidonebulosis.

$\gamma$ minor, cupreo-nitens; corporis hirsutie pallidâ.

It will be expected that $I$ assign my reasons for regarding as sexual varicties of the same individual,

(p) Tab. 10, c. 2. 8. fig. 19. $a a$, 
two insects, which, at first sight, appear so extremely unlike each other, as $A$. crerulescens and A. cenea. The authority of the Baron de Geer will have great weight with every entomologist, and he informs us that he took both these insects out of the same nidus. These are his words, "Les abeilles, que je tirai de ces coques et qui n'étoient gueres plus grandes que des mouches domestiques, étoient de deux couleurs; les unes d'un bleu violet foncé et comme noirâtre, mais luisant, ayant les yeux noirs, et la tête et le corps couverts de poils cendrés et blanchâtres. Les autres abeilles avoient le fond de la tête, de tout le corps et des pattes d'un verd foncé, bronzé et luisant; mais toutes ces parties, en particulier le corcelet, étoient couvertes de beaucoup de poils roux, qui sur le ventre n'etoient cependant placés que de chaque côté et le long de bord postérieur de chaque anneau, et ces poils formoient sur le ventre du mâle comme des rayes transversales rousses, tandis qu'en dessous i! étoit tout ras. Les antennes étoient noires et les yeux à réseau d'un verd clair. J'ai lieu de croire, que les abeilles bleues étoient les femelles, et les vertes les mâles, puisque ces derniers étoient un peu plus petits que les autres $(q)$ "

This account sufficiently proves his insects to be only different sexes of the same species, and that purs are synonymous with his will appear evidently

(q) Tom. 2. ptie. 2. p. 752. 
if they are compared with the description it gives of them. The colour of the head and trunk of the female varies, in some it is black, in others violet, the wings are sometimes transparent with a brown cloud at their tips, and sometimes they are brown, clouded with white; in his specimens, these were, as he informs us afterwards, "transparentes et sans couleur," but as he extracted them, before their time, from the coccoons in which they were inclosed, they were probably not come to their proper colour. My opinion, derived from this illustrious author, of the identity of $A$. ccerulescens and $A$. anea, is still further confirmed by this circumstance, that the former is always a female, and the latter, as invariably, a male insect.

Linneus to his $A$. carulescens applies the term " fusca," which will not agree with our specimens, nor indeed with that preserved in the Linnean cabinet, but in his description in the Fauna Suecica, he says, "Corpus totum atrum, cærulescens, immaculatum."

Many authors have looked upon Geoffroy's Apis tota viridi-cuprea $(r)$ as synonymous with the male of our insect, but his description appears to me at variance with it, for he says of his "Elle est médiocrement velue. Les poils du bord des anneaux clu ventre sont blancs." Whereas $A$. cenea is very

(r) Hist. Ins. Par. 2. p. 415. n. 15. Apis cuprea. Fourcroy. Ent. Par. n. 15.

hairy, 
APIS. (**. c. 2. 8.)

hairy, and the fringe of the segments of the abdomen is rufo-fulvous, and not white.

De Geer informs us that the larvæ of this Apis are exposed to the attacks of more than one Ichneumon $(s)$. Panzer has figured both sexes very accurately.

56. A. nigra, rufo-villosa; abdomine segmentis Tunensis。 margine pallidioribus; ano masculo emarginato.

Apis Tunensis nigra, thorace hirsuto rufo, abdominis segmentis margine rufo-ciliatis.

Fal. Ent. Syst. Em. n. 87.

Apis Tunetana. Lin. Syst. Nat. Ed. Gmel. p. 2773. $n .71$.

FIG. Apis aurulenta hirsuta, fulva, capite nigro, abdomine atro, nitido, segmentis margine postico fulvo hirsutis, subtus lanâ fulvâ.

Panzer. Fn. Ins. Germ. Init. n.63. tal. 22?

MUS. D. Marsham, Kirly.

Long. Corp. Lin. $4 \frac{3}{4}$.

$H a l$. In Suffolciâ, a me apud Henley prope Gippovicum, in aggere argillaceo tempore autumnali lecta.

DESCR. Acul.

CORPUS fusco-nigrum, punctulatissimum, rufo-villosum.

CAPUt magnum. Maxilla validæ, prominentes, supra tomentoso-fulvescentes, apice tridentatæ, dente exteriori acuto. Anțennce vix capitis longitudine, tenues, subfiliformes.

(s) Tom. 2. ptie. 2. p. 753, 887, 888. Amongst others to İchneumon Apum. Vill. Ent. Eur. 3. n. 249.

Truncus 
APIS. (**. c. 2. 8.)

Truncus supra rufo-subhirsutus, subtus pube pallidiori. Squamulce ferruginex. Alce fuscescentes, albido subnebulos $x$, nervis nigricantibus. Pedes rufescente-hirti, scopulis ferrugineis. Tibiarum Spinulce testacex.

Авдомеn subglobosum, pube ferrugincâ, nisi a latere vix conspicuâ, molle; segmentis margine villoso-pallidioribus. Venter lanâ densâ, ferrugineâ vestitus.

Maris Corpus subtus villoso-pallidum, supra ferrugineo-hirsutum. Maxillce forcipatæ, supra glabræ, apice bidentatæ dente exteriori prælongo, interiori obsoletiusculo, truncato. $\mathrm{Fa}$ cies ante antennas vellere denso cinerascenti tecta. Antennce thorace breviores. Ala hyalinæ, apice obscuriores. Pedes pallido-hirti. Spinula nigræ. Aldomen obscurè nigroæneum, per fascias hirsutum. Anus incurvus, emarginatus. Venter apice bidentatus.

Obs. In maribus segmentorum aldominalium fimbria marginalis haud allescit.

This insect answers the description which Fabricius has given of his $A$. Tunensis so well, that I think there can be little doubt of its being synonymous with it. I am not so certain that it is the $A$. aurulenta of Panzer, as his figure and description, although they come very near, do not quite coincide with my specimens of it. I do not know that it has been taken in England by any one besices Dr. Goodenough and myself. 
57. A. corpore femineo atro, hirsuto; fronte bi-licornis. . corni ; abdomine æneo, hirsutie rufâ : corpore masculo hirsuto-cinerascenti; fronte albidâ; abdomine æneo, hirsutie rufâ, ano integro.

\section{ACUL.}

Apis bicornis fronte bicorni, capite nigro, abdomine hirsuto rufo.

Lin. Syst. Nat. Ed. 12. छ Gmel. p. 2773.n.10. Fn. Suec. 1691.

Fab. Ent. Syst. Em. n. 86.

Ross. Fn. Etrusc. Mantiss. n. 310.

Forst. Cat. Brit. Ins, n. 710. Apis, n. 4.

FIG. Vill. Ent. Eur. 3. n.9. tab. 8. fig. 23.

Reaum. tom. 6. Mem. 3. p. 86. tal. 8. fig. 11.

Harris. Exp. Eng. Ins. tal. 49. fig. 4.

Christii Hymenopt. p. 159. tab. 12. fig. 9.

Apis fronticornis fronte bicorni, capite nigro, abdomine æneo, hirsuto-cinereo, subtus lanâ flavâ.

Panzer. Fn. Ins. Germ. Init. n. 63, tab. 20.

MUS. D. Smith Linnean, Marsham, Latham, Haworth, McLeay, Trimmer, Sowerby, Lathbury, Kirby.

\section{MAS.}

Apis rufa, fusca, abdomine rufescente fronte albâ.

Lin. Syst. Nat. Ed. 12. E Gmel. p. 2772. n.9. Fn.

Suec, 1690.

Fal. Ent. Syst. Em. n. 88.

Miill. Zool. Dan. n. 1899.

Ross. Fn. Etrusc. n. 913.

Vill. Ent. Eur. 3. n. 8 ?

Berkenhout. Synops. 1. p. 158. n. 2.

Forst. Cat. Brit. Ins. n.709. A A is, n. 3.

Apis vernalis. Ilid. n.720. Apis, n. 14. 
A P IS. (**. c. 2. ग.)

Apis sylvestris parva, abdomine breviore, toto supina parte lanugine rufâ vestito; thorace lanugine albicante.

Rai. Hist. Ins. p. 242, n. 7.

FIG. Sulz. Hist. Ins. tal. 27. fig. 15.

Harris. Exp. Eng. Ins. tab. 49. fig. 7.

Panzer. Fn. Ins. Germ. Init. n. 56. tal. 10.

Apis frontalis hirsuta, fronte hirsutissima, antennis longis, abdomine pilis rufis vestito.

Vill. Ent. Eur. 3. n.127. tab. 8. fig. 28.

MUS. D. Smith Linnean, Marsham, Latham, Haworth, $M \subset$ Leay, Lathlury, Sowerly, Francillon, Trimmer, Drury, Kirly.

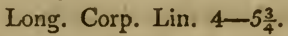

Hab. Barhamix. In Lapidum cavitatibus cellulas ex terrâ humectatâ conficit. Reaumur. Vere novo mas obvius, æstate florenti provenit femina, flores hortoruin frequentans.

DESCR. Acul.

CORPUS atrum, subtus cinereo-hirsutum.

CAPU T atro-hirsutum, trunci ferè magnitudine. Maxilla forcipatæ, validæ, apice tridentatæ, dente intermedio minuto, intimo truncato, obsoleto $(t)$. "Ad basin maxillarum duo cornicula incurva, rigida nec mobilia, hirsutie vix longiora, nigra, infra apicem a parte exteriori denticulo notatæ," faciem armant $(u)$. Antenne capite longiores, nigræ.

TRUNCUS supra anticè atro-hirsutus, posticè cinereo. Squamule atræ. Alce subhyalinæ,

(t) Tab. 10. **. c. 2. 8. fig. 9 .

(u) Ibid, fig.6. $a a .8$ fig. 7 . 
apice paulò obscuriores; nervis, strigâque marginali prope apicem, nigris. Pedes rufescente-hirti. Femora barbâ densâ cinerascenti. Plante posticæ dilatatæ. Scopule fulvo-aureæ. Digiti articulo extimo ferrugineo. Spinula testaceæ.

AsDomen ex oblongo subglobosum, nigroæneum, hirsutie densa rufâ vestitum. Venter lanâ fulvo-aureâ tectus.

Obs.: In adultioribus trunci et aldominis tergi hirsuties cinerascit, et ventris pallidior.

$\operatorname{Var} . \beta$ frontis cornibus rectis, acutis $(x)$.

Maris Corpus hirsuto-albicans. Caput cinereovillosum, inerme. Facies anticè et inter antennas barbâ densâ albicanti. Verticis pili atri. Maxillce apice bidentatæ $(y)$. Antennce filiformes, trunci ferè longitudine. Trunci hirsuties longissima, anticè rarior. Squamulce piceæ. Abdomen per fascias rufo-hirsutum. Anus subinflexus, integer(z). Venter glabriusculus.

$V a r . \beta$ dimidio minor.

It is observed by Linneus, under $A$. bicornis, that Forskæhl saw that insect and $A$. rufa " copulâ connexas;" and whoever compares them both together will find that they differ only in such circumstances as are usually distinctions of sex,

(x) Tab. 10, **. c. 2, 8, fig. 8.

(z) Ibid, fig. 20.

(y) Ibid. fig. 10. 
and that the former is constantly furnished with an aculeus, while the latter has no such instrument, but only the male organs: these reasons have induced me to consider them as different sexes of the same species.

Panzer's $A$. fronticornis is evidently nothing more than the aculeate of our $A$. licornis, which agrees with the authentic specimen in the Linnean cabinet. His description appears to have been drawn from an insect that had been long disclosed, for in such the hair that covers the upper side of the abdomen fades to cinereous, and that upon the venter becomes paler than in more recent specimens. Linneus has described the abdomen by the term "rufum," which, in fact, belongs only to the hirsuties that covers it, as the abdomen itself is nigro-æneous in both sexes; this circumstance probably might lead Panzer, whose specimen, as I have just observed, was probably an old one, to look upon his insect as distinct from A. bicornis. The figure which Christius has given of the aculeate is far from a good representation of it, and his fig. 10. which he calls the other sex, appears to be a distinct species; it is certainly not $A$. rufa. That which he afterwards figures for A. rufa is a very different $\operatorname{insect}(a):$ his $A$. pusilla $(b)$ comes very near to it, and I should refer to it as such if the antennæ were not so short in
(a) Vid. supra, p. 47 。
(b) Hymenopt. P. 161, tab, 12. fig. 14. 
his figure; whereas, in A. rufa they are strikingly long. Forster, in his catalogue of English Insects, has made two species out of the male; our $\alpha$ he calls $A$. vernalis, under which name he sent it to Linneus, and it is still in the cabinet. That illustrious naturalist very properly considered it as merely a variety of his $A$. rufa, as appears from a M.S. observation in his interleaved copy of the Systema Naturæ, which Dr. Smith very kindly allowed me to consult. Indeed it differs from $\beta$, which I take to be the common $A$. rufa, in nothing but size, being more than twice as big. Villars seems also to have fallen into the same error, as his $A$. frontalis exactly resembles our larger insect; his $A$.rufa is probably intended for our $\beta$ : he has placed the former amongst his Bombinatrices; but where hirsuties is taken for the only diagnostic of that family, this is no proof of its being another insect, since $A$. rufa is as hairy as many genuine Bombinatrices. That which Scopoli $(c)$, and after him Schrank $(d)$, have given for $A$. rufa, appears to be a different insect; for the terms by which they define theirs, viz. "nigra; thorace abdominisque apice rufo," will scarcely agree with the true one; I have therefore made no reference to them. I think there is little doubt that Reaumur intended this insect by his "Mouche maçonne dont la maçonnerie n'est que de pure terre $(e) ; "$

(c) Ent. Carniol. n. 816.

(e) Tom. 6. Mem. 3. P. 92.

(d) Enum. Ins. Austr. n. 803. 
of which he says, " J'hésite presque à donner le nom d'antennes à deux cornes qui s'élevent en devant de sa tête, car elles ne sont pas flexibles $(f)$ :" words which clearly allude to the remarkable horns which the fernale carries upon its forehead. It is rather singular that no Entomologist should have before discovered this insect to be synomymous with $A$. licornis. This great naturalist is the only author that has given any account of the mode of nidification of this species $(g)$. It is not easy to ascertain what is the use of the horns with which the head of the females is armed, but it is probable that they assist her in the construction of her cells. Rossi has described another species distinguished by the same peculiarity $(h)$, of which Panzer has given a figure $(i)$. I am not sure that my variety $\beta$ may not be a distinct species; but as it differs in nothing from $\alpha$ but the shape of the horns, I have not ventured to separate them. The larger males ( $A$. vernalis, Forster) appear early in the spring; one of these, upon a very windy day in March, once amused me much by flying round me for some time, and at length alighting upon me. Upon variety $\beta$ I found, in great numbers, a very small Acarus, the same which Reaumur informs us he took upon $A$. violacea. It was a hexapod with two long hairs in its tail, which seem-

(f) Tom. 6. Mem. 3. p. $86 . \quad(g)$ Vol.1. p.1s1. Reaum. 6. Mem. 3. p. $85,86 . \quad$ (h) A. cornigera, Fn. Etrusc, n. 925.

(i) Fu, Ins, Germ, Init, n. 55, tab. 15. 
A PIS. $(* *$ c. $2 . \delta$. $)$

ed to perform the office of feet: since it has not hitherto been noticed by any other author, I shall describe it in the margin $(k)$.

58. A. hirsuta, aterrima; abdomine, tarsisque qua-licolor. . tuor posticis, hirsuto-ferrugineis.

Apis licolor nigra, hirsuta; abdomine fulvo.

Schrank. Enum. Ins. Austr. n. 806.

Apis rufescens nigra; abdomine tibiis plantisque rufis. Mus. Liesk. p. 80. n. 516.

Lin. Syst. Nat. ed. Gmel.p.2790, n. 169.

Apis nigra; abdomine fulvo.

Geoffr. Hist. Ins. 2. p.419. n. 27.

Apis rustica. Fourcroy. Ent. Par. n. 27.

FIG. Apis bicolor. Vill. Ent. Eur. 3.n. 121. tab. 8. fig. 27. Apis fusca Christii Hymenopt. p. 182. tab. 14. fig. 10. Apis fusca atra pubescens, abdomine subtus, marginibus segmentorum, tarsisque, fulvo-villosis.

Panzer. Fn. Ins. Germ. Init. n. 56. tab. 11.

MUS. D. Marsham, Latham, Francillon, Kirly.

Long. Corp. Lin. $5 \frac{3}{4}$.

Hat. Barhamiz in floribus semel capta. Bis apud Blakenham Magnam in aggere aprico. Recens int sectum moscham spirat.

DESCR. Ácul.

CORPUS aterrimum, hirsutum.

(k) A. rufescens; margine, lineâque trànsversâ, pallidis; ano Apurit; utrinque setâ longissimâ instructo.

Reaum. Hist. Ins. tom.6. Mem. 2, p.52, 53. tab. 5. fig. 8, 9.

DESCR. Arenulâ minor, hexapus. Anus fuscus setis dua bus longissimis.
T 2
Caputy 
CApUt trunco minus. Maxille validæ, subforcipatæ, apice tridentatæ, dente exteriori longiori acuto, interiori obsoletiusculo truncato. Antennce subclavat $x$, capitis ferè longitudine.

Truncus. Squamula atræ, nitidæ. Ala subhyalinæ, apice fuscæ, nervis nigris. Pedes atro-hirti, tibiis posticis, tarsisque omnibus, undique hirsuto-ferrugineis.

AвDомEN subglobosum, nigrum, supra et infra hirsuto-ferrugineum; segmentorum dorsalium margine densiùs villoso.

Obs. In adultioribus abdominis hirsuties rufa.

A. bicolor, on account of its hairiness, is placed amongst the Bombinatrices by Schrank, Villars, and Geoffroy; but its inflected lip, and the hairy brush which covers the underside of its abdomen, prove that it belongs to the present family. Panzer's figure is not quite so accurate as his usually are, for the base of the dorsal segments of the abdomen, of this insect, is covered with ferruginous hair as well as the margin, although that which fringes the margin is the thickest.

$$
\text { **. d. } 1 \text {. }
$$

- lonsicor-59. A. nigra, pallido-villosa; thorace, abdominisque nis. basi, hirsuto-fulvis; ano femineo pallido.

\section{ACUL.}

Apis Bryorum nigra; thorace abdominisque basi hirsuto-fulvis.

Schrank. Enum. Ins. Austr. n. 812. 
Lin. Syst. Nat. Ed. Gmel. p. 2786. n. 134.

Vill. Ent. Eur. 3. n. 30.

Apis longicornis. Miller, int. not. Graian, supr. citat.

FIG. Andrena strigosa thorace rufo-villoso, abdomine nigro subnudo, margine laterali segmentoque penultimo albis, basi apiceque rufis.

Panzer. Fn. Ins. Germ. Init. n.64. tab. 16.

MUS. D. Marsham, Haworth, $M^{\circ}$ Leay, Sowerby, Trimmer, Kirby.

\section{MAS.}

Apis longicornis antennis longitudine corporis hirsuti, fulvique.

Lin. Syst. Nat. Ed. 12. छ Gmel. p. 2770. n. 1. Fn. Suec. 1684.

Vill. Ent. Eur. 3. n. 1.

Fn. Frid. n. 643.

Miill. Zool. Dan. n. 1895.

Pod. Mus. Grac. p. 109.

Scop. Ent. Car. n. 794.

Ross. Fn. Etrusc. n. 922 ,

Apis hirsutie flavescens, fronte flavâ, antennis articula* tim compressis, corpus æquantibus.

Geoffr. Hist. Ins, 2. p. 413. n. 10.

Apis longicornis. Fourcroy. Ent. Par. n. 10.

Apis sylvestris domestic gissimis retro reflexis.

Rai. Hist. Ins. p. 243.

Eucera longicornis. Scop. Ann. Hist. Nat, 4. p. 8, n. 1.

Fal. Ent. Syst. Em. n. 1.

FIG, Swammerdam. Bibl. Nat. tab.26. fig.6.

Scheffer. Icon. tab. 44. fig. 3.

Christii Hymenopt. p. 142. tab. 11. fig. 9.

Harris. Exp. Eng. Ins. tal.49. fig. 5.

Barbut. Gen. Insect. tab. 15. Apis, fig. 7.

Eucera longicornis, Panzer. Fn. Ins. Germ. Init. n.64. tab.21. 
A PIS. (**. d. 1.)

MUS. D. Simith Linnean, Marsham, Latham, Haworth, McLeay, Donovan, Lathlury, Sowerly, Trimmer, Kirly.

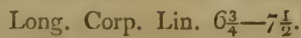

Hal. Barbanix. In fioribus haud rara. Mense Julio, medio copulantur prope terram volitantes in gramine detonso. In puteo cylindrico terræ ova deponit femina.

DESCR. Acul.

CORPUS nigrum, subtus pallido-villosum.

CAput. Maxilla apice fulvæ. Labium hirsutorufescens. Antenna capite longiores, fusconigrx. Facies hirsuto-cinerascens.

Truncus supra pube densâ, mollissimâ, fulvoflavâ tectus. Squamule obscurè rufæ. Ala hyalinæ, apice nigricantes; nervis ferrugineis, longitudinalibus duobus interioribus nigris. Pedes hirsuto-fulvescentes. Femora pallidobarbata. Tilic antica extrorsum tomentosopallidx. Spinulce testaceæ. Scopulce ferruginex. Digiti articulo extimo rufo.

Авдомen latum, fusco-nigrum, basi flavescente-pubescens, segmentis duobus intermediis utrinque, antepenultimo etiam margine, tomentoso-albicantibus. Anus ipse tomentoso-pallidus. V'enter convexus, fuscus, anum versus pubescens.

Maris Corpus subtus villoso-albicans. Maxilla fusco-nigræ, interdum apice fulvæ. Labium et Nasus flava. Gence barbâ longâ densâ albicanti. Antennce corporis ferè longitudine. 
A PIS. (**. d. 1.)

Truncus supra fulvo-pubescens. Pedes minùs hirsuti. Tilice anticæ tomento nullo. Scopulce pallidiores. Abdomen magis angustum, lateribus albido-villosis, segmentis duobus anticis fulvo-pubescentibus, reliquis nigro, sed vix conspicuè, pilosis. Segmentum antepenultimum pallido-ciliatum. Ani fulvescit fimbria. Venter planiusculus, villosulus.

$V a r . \beta$ abdomine subrotundo.

Obs. Interdum abdominis segmenti antepenultimi fimbria nigricat. In adultioribus thoracis et abdominis pubes fulva cinerascit.

I do not claim the sole merit of discovering the other sex of this species, and that the long antennæ, which form the distinction of the Eucera of Scopoli and Fabricius, are merely the character of the males; for Miller, in Mr. Gray's interleaved copy of the Systema Naturæ, before quoted, has described the female of $A$.longicornis in the following terms: "Fæmina antennis thorace lrevioribus, abdomine latiore segmentis tribus ultimis margine et lateribus pilosis, albicantibus." M. Latreille, also, appears to have made the same observation; for in a letter to Mr. Mac Leay, dated April 26, 1801, he says, "Demandez un peu a votre ami s'il a trouvé la femelle de l'Eucera longicornis : car toutes ces abeilles à longues antennes ne sunt que des mâles." The female has been described both by Schrank and Panzer; the latter has given a very accurate figure of it, under the name of Andrena 
strigosa. Variety $\epsilon$, at first sight, looks like a distinct species, but the difference in the shape of the abdomen, seems to arise from the accidental circumstance of the anal segments being more drawn in than in $\alpha$, so that the base, of each of the three last, is quite covered by the apex of that which precedes it: whereas, in \& the whole segment is exerted.

linguaria.60. A. hirsuto-cinerascens, abdomine nigro.

Eucera linguaria antennis nigris longitudine corporis, thorace cinereo, abdomine nigro.

Fal. Ent. Syst. Em. n. 5.

Lin. Syst. Nat. ed. Gmel. p. 2770. Apis, n. 25.

Vill. Ent. Eur. 3. n. 66.

Apis tumulorum. Forst. Cat. Brit. Ins, n. 707. Apis, n. 1 ?

Apis longicornis Var. Ross. Fn. Etrusc. n. 922?

FIG. Schaff: Icon. tal. 22, fig. 16.

Panzer. Fn. Ins. Germ. Init. n. 64. tab. 22.

Apis tumulorum. Romer. Gen. Ins. p.61. tal. 27. fig. 14.

Christii Hymenopt. p. 198. tal. 17. fig.9.

Donovan. Nat. Hist. Brit. Ins. 5. tab. 151. fig. 2.

MUS. D. Donovan, Kïly.

Long. Corp. Lin. 6.

Hal. Prope Londinum. A. D. J. Trimmer accepi.

DESCR. Mas.

CORPUS nigrum, villoso-cinereum.

Capu t. Maxille nigræ. Labium et Nasus flava.

Gence barbâ densâ, albicanti. Antennce nigræ, corporis ferè longitudine.

TrunCU: 
Truncus supra hirsuto-cinereus. Squamula piceæ. Alce hyalinæ, nervis ferrugineis. $P e-$ des pilis albicantibus hirti. Spinulce flavæ. Scopula fulvescentes. Digiti articulis extimis testaceis.

Авдомеn subglobosum, nigrum, basi cinereo, sed rariùs, villosum; segmento penultimo fimbriâ rufescenti. Venter villosulus.

This species resembles not a little the male of the preceding, variety $\beta$, but it is much smaller, the hirsuties of the body is cinereous, and the base of the abdomen is not so thickly covered with it. It has been mistaken, by many authors, for $A$. $t u$ mulorum of Linneus, but this, as we have shewn above (l), belongs to the genus Melitta, and exhibits no other mark of relation to the Eucerce, than its antennæ, which are longer than the thorax; a circumstance which it possesses in common with many other males of the family to which it belongs. Linneus having placed it next to $A$. longicornis, and employing terms in the definition of it, which imply that it is related to that insect, succeeding Entomologists took this for granted, and thus have erred universally concerning this Apis, not one author, that I have had an opportunity of consulting, being acquainted with the true $A$. tumulorum, and the majority of them mistaking the insect now pefore us for it. Yet had the definition which

(l) Vid. supr. p. 56, 57.

Linneus 
Linneus has given of it been attended to, this mis. take would have been avoided, for the terms " $\mathrm{Pe}$. dibus, maxillisque flavescentibus" will not by any means agree with $A$. linguaria. In the Fauna Suecica other characters are added to the above, which, if they had not been overlooked, would have furnished a further proof, that this insect was not the insect of Linneus. "Magnitudine dimidiæ Muscce domestice; toto corpore nigra, exceptis pedibus et maxillis pallidè luteis. Antennæ filiformes, corporis ferè longitudine, subtus pallidiores." Fabricius finding that the definition of Linneus would not suit the insect which he mistook for A.tumulorum, has altered it, omitting " pedes flavi," the most striking distinction of the true one, and adding hirsuties, a circumstance which does not belong to it $(m)$. I am not, at present, acquainted with his Eucera tumulorum.

pollinaris.61. A. nigra, albido-pubescens; thorace flavesn centi; abdomine fusco, polline pallido.

FIG. Tal. 17. fig. 3 .

MUS, D. Banks. Hal. In Angliâ.

Long. Corp. Lin. $7 \frac{\pi}{3}$.

DESCR. Acul.

CORPUS nigrum, pube albidâ.

Caput. Oculi magni, prominuli. Labium pal. lido-barbatum. Antennce nigræ.

(m) Antennis longitudine corporis hirsuti nigrique, mans dibulis Alavis.

Truncus, 
Truncus. Thorax pube flavescenti mollis. Squamule fulvæ. Alce subhyalinæ; nervis, excepto costali fusco, ferrugineis. Pedes nigri, albido undique pilosissimi, postici potissimùm.

Aв Domen fuscum, basi albido-pubescens, squamulis $\int$. pilis brevissimis pallidis, anum versus præcipuè, incanum. Venter segmentis margine pilis pallidè aureis ciliatis.

This insect is somewhat similar to the aculeate of $A$. longicornis, but it is much larger, and its abdomen is nearly covered with minute scales. Part of the thorax of the specimen in Sir J. Banks's cabinet, has evidently had the hair rubbed off; this defect is attempted to be remedied in the figure I have given of it. I have never seen this insect in any other cabinet; its male, I have very little doubt, is one of the Eucerce, or long horned bees.

62. A. nigra, hirsuto cinerascens; antennis subtus Druriella fulvis; abdomine segmentis posticis utrinque mucronatis.

FIG. $T a b .17$. fig. 4.

MUS. Regina (n), D. Drury Apis, n. 40, Kirby.

Long. Corp. Lin. $4 \frac{1}{2}$.

Hab. In Angliâ, rarissima.

DESCR. Mas.

CORPUS atrum, hirsuto-cinerascens.

( $n$ ) In the Observatory at Richmond, the left hand specimen in the last row of Apis.

Caput, 
$\mathrm{C}_{\mathrm{APU}} \mathrm{x}$. Proboscis brevis. Maxilla apice rufæ, Labium luteum limbo nigricanti. Nasus flavescens. Antennce corporis vix longitudine, piccæ, subtus fulvæ, scapo pedicelloque nigris. Truncus. Squamula nigræ, villosulæ. Aløe hyalinæ, nervis ferrugineis. Pedes cinereo, hirti, tarsis articulo extimo rufo.

A В DOMEN villosum, segmentis fasciâ mediâ villoso-albidâ, penultimo et antepenultimo utrinque dente acuto armatis.

In honorem D. Drury, operis entomologici splendidissimi auctoris, cujus museum insectorum rarissimorum undique conquisitorum gazophylacium ditissimum, hanc Apem ab illo accep. tam, nominavi.

This rare insect is extremely distinct from any of the preceding ones, and appears to have been hitherto unnoticed; the teeth which arm the last segments of the abdomen, furnish an excellent characteristic:

$$
\text { **. d. } 2 . \alpha \text {. }
$$

- Limacula-63. A. nigra, cinereo-subvillosa; facie anticè, oreta. que, flavescentibus; ano tomentoso-incano.

FIG. Apis limaculata atra griseo pubescens, fronte flavà maculis duabus atris, abdomine apice bifido, fasciis apiceque griseis.

Punzer. Fn. Ins. Germ. Init. n.55. tal. 17.

MUS. D. Marsham, Haworth, Drury, Kirly. Long. Corp. Lin. $4 \frac{I}{2}$. 
Hat. In Suffolciâ. Circa aggerem apricum prope

Woodbridge volitantem feminam bis cepi.

DESCR. Acul.

CORPUS nigrum, cinereo-villosum.

CAPUT latum, hirtum. Maxille flavæ, apice fuscæ. Labium pallidè flavum posticè utrinque puncto nigricanti. Facies anticè pallidè flava, flavedine in lineam attenuatam, elongatam, apice paulò dilatatam truncatam, antennas versus medio excurrente. Oculi, in vivo, chrystallino-cæsii, fundo favoso. $A n$ tennce capitis ferè longitudine, nigræ, subtus rufo-piceæ. Vertex atro-pilosus.

TRUNCUS supra pube nigricanti rariùs consitus, pilis cinereis immistis. Squamula subtestaceæ. Alce hyalinæ, nervis nigricantibus, apice aveniæ. Pedes picei, pallido-hirsuti, præsertim tibiæ posticæ. Scopulce obscurè ferrugineæ, ast certo situ sub-nigræ.

Ав DомEN ex rotundo ovatum, pilis nigris rigidiusculis anticè rariùs consitum, basi intimâ cinereo-villosâ; segmentis tribus anticis margine, proximis duobus totis, tomentoso-canescentibus. Segmentum ultimum minutissimum, acuminatum, fasciculo pilorum, rigidorum et quasi conglutinatorum, utrinque munitum, unde mucronatus mucrone bifido anus videtur. Venter convexiusculus, villosulus, segmentis margine pallidis.

$\operatorname{Var} . \beta$ ore facieque anticè ex flavo rufescentibus, pedibus nigris. 
Panzer's figure of this insect is extremely accurate, cxcept that the tibiæ and tarsi are more yellow than in any specimens I have met with; the posterior tibix, from the pollen, of which they usually retain some quantity, appear yellower than the others, but this not the real hue of the hairs, which are pale with little or no tinge of that colour. The eyes, in his specimen, when the insect was living, he informs us were of a fine green, "læte virides," in those that I took they were bluegrey. The bifid mucro, which he mentions as terminating the anus, is merely a little tuft of rigid hairs which guard, on each side, the minute segment that terminates the abdomen; under a common lens these have exactly the appearance he describes. What he calls spots of the front, are rather lobes, for they are not entirely, but only in part, insulated from the blackness of the posterior part of the face, by the intervention of the yellow, which is the colour of the anterior.

- furcala. 64. A. corpore femineo nigro, griseo-pubescenti; facie anticè, labio, anoque, villoso-ferrugineis: corpore masculo atro, cinereo-pubescenti; facie anticè, labioque, flavis; abdomine apice furcato.

FIG. Apis furcata cinereo pubescens, antennarum articulo primo fronte labioque flavis, abdomine apice furcato tarsis ferrugineis.

Panzer. Fn.Ins. Germ. Init. n. 56. tal. 8. Mas.

Tal. 17. fg. 5. Acul. fig. 6, mas. 
MUS. Acul. D. Smith Linnean. n. 1009. Acal. et Mas. D. Marsham, Trimmer, Kirly. Mas. D. McLeay.

Long. Corp. Lin. $5 \frac{I}{2}-6 \frac{1}{2}$.

$H a b$. In Suffolciâ, sed rarior. Prope Londinum frequentior. In lignis exsiccatis nidificat.

DESCR. Acul.

CORPUS nigrum, pube subgriseâ.

CAPUT. Labium pilis ferrugineo-aureis tectum. $V$ ertex atro-pilosus. Facies ante antennas ferrugineo-subhirsuta. Antennce capitis longitudine, nigræ.

TRUNCUS supra pube fulvescenti, sed disco rariùs, vestitus. Squamulæe atræ. Alæe paulò infuscatæ, apice obscuriores aveniæ, nervis nigris. Pedes grisescente rariùs villosi. Tilice posticæ scopâ densâ admodum. Plantee ultimi paris fasciculo pilorum rigidiusculorum ferrugineo coronatæ. Scopulce nigricantes.

АвдомеN oblongum, fusco-nigrum, basi grisescente-pubescens. Anus mucronatus, tomentoso-ferrugineus. Venter nitidiusculus, segmentis margine fulvescente-villosis.

Maris Corpus cinereo-villosum. Labium flavum, punctis duobus posticis, margineque, nigris. Facies anticè fulva, vel fulvo-flava. Antennae scapo antrorsum lineolâ flavâ interruptâ inscripto. Truncus supra villoso-grisescens. Pedes hirsutie subcincreâ. Tilice posticæ fasciculo pilorum nullo. Digiti articulis extimis, Scopuleque ferruginea. Aldomen ex globoso cordatum, 
cordatum, inereo-hirtum, segmentis ultimis atro-pilosis. Anus furcatus dentibus patulis (o). Venter posticè depressus concavus tomentoso-fulvescens.

$V$ ar. $\beta$ corporis hirsutie griseấ; antennis scapo immaculato.

As the sexes of $A$. furcata are so unlike each other, that no common character would include them both, I have, therefore, been under the necessity, as in some former instances, of making a separate one for each. I do not give these individuals as male and female upon my own authority, but Mr. James Trimmer, upon whose accuracy I can rely, has taken both out of the same nest. Upon their mode of nidification I have enlarged before $(p)$. Panzer's figure and description, which belong to the male, vary a little from our specimens, but I think there can be no doubt of his intending the same insect.

vulpina. 65. A. atra, villoso-pallescens; thorace flavescenti; abdomine segmentis margine pallidis; femoribus intermediis magnis, clavatis.

FIG. Apis vulpina ferrugineo villosa, antennarum articulo primo fronte labioque flavis, abdomine nigro, segmentis posticè ferrugineo villoso-fasciatis.

Panzer. Fn. Ins. Germ. Init. n.56. tal.6?

MUS. D. Haworth.

Long. Corp. Lin. 5.

$H a b$. In Angliâ rarissima.

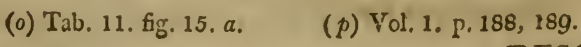

DESCR. 


\section{A.PIS, $(* *$, d. $2, \alpha$.)}

DESCR. Mas.

CORPUS atrum, pube pallescenti.

CAPUT hirsutum. Gence barbâ densâ, longâ. Maxillce nigræ, maculâ flavâ. Labium flavum, margine antico, punctisque duobus posticis, nigris. Facies ante antennas subrufa, maculis duabus quadratis atris. Antenne nigræ, basi antrorsum flavæ.

Truncus supra pube densâ fulvo-flavâ mollis. Squamulce nigræ. Alce hyalinæ, nervis nigris. Pedes albido-hirti. Femora clavata, intermediis majoribus. Digiti obscurè rufescentes.

Ав Dомen ovatum, atro-subpilosum, segmento primo villis flavescentibus pubescente, reliquorum marginibus pilis rufo-pallidis latè tectis. Venter hirtus.

I take this insect to be a variety of Panzer's $A$. vulpina. In Mr. Haworth's specimen, the only one that I have seen, the black spots on the anterior part of the face are larger than in the figure given by that author, and the abclominal fascix have a very slight tinge of red: the very large intermediate thighs are the most striking characteristic; I have, therefore, introduced them into my definition.

66. A. grisescente-villosa; ore flavo; abdomine otundata, . segmentis margine subrufis; thorace femineo nigricanti, masculo fulvo.

VOL. II. 
MAs. $\beta$.

Apis rotundata nigra, cinereo hirt3, abdomine aubgleboso segmentorum marginibus albis.

Fal. Ent. Syst. Em. n. 80?

Lin. Syst. Nat. Ed. Gmel. p. 2778. n. 88 ?

Vill. Ent. Eur.3. n. 76 ?

Apis subhirsuta cinerea, abdomine nigro, segmentis albidis; fronte flavescente.

Geoffr. Hist. Ins. Par, 2. p.413. n. 11.

Apis terrestris. Fourcroy. Ent. Par. n.11.

FIG. Panzer. Fn. Ins. Germ. Init. n. 56. tab. 9.

MUS. D. Marsham, McLeay, Haworth, Drury Apis, n. 53,

Trimmer, Kirly.

Long. Corp. Lin. $4 \frac{1}{2}-5 \frac{1}{2}$.

$\mathrm{Hal}$. Prope Londinum. Flores Erica in arenario quodam juxta Combe Wood supra dict. uterque sexus frequentabat, Julio ineunti, 1801.

DESCR. Acul.

CORPUS atrum, pube grisescenti.

CAput. Maxille nigræ, basi flavæ. Labium flavum, posticè utrinque puncto nigricanti. $F a-$ cies anticè pallidè flava, flavedine in lineam attenuatam, elongatam, apice pauld dilatatam, antennas versus medio excurrente; fulvo-pubescens. Vertex atro-pilosus. Gence barbâ albidâ. Oculi, in vivo, chrystallino-virentes, fundo favoso. Antennce capitis vix longitudine, nigræ.

Truncus supra nigricanti rariùs pilosus, limbo fulvescenti. Squamule subtestacex. Alce hyalinæ, apice paulò obscuriores aveniæ, nervis nigris. Pedes grisescente-hirti. Femora postica 
APIS. (**. d. 2. «.)

postica apice fulvo-pubescentia, antica barbata. Tibice posteriores scopâ densâ. Scopule nigricantes.

АвдомеN subglobosum, pilis atris adspersum, segmentis quatuor anticis margine tomentososubrufis $\int$. fulvescentibus. Anus tomentosoincanus. Segmentum primum utrinque fulvescente-villosum. Venter convexus, nigropiceus.

Maris Facies tota ante antennas lutea. Aniennce capite longiores, scapo antrorsum flavo, apice articulo primo breviusculo. Vertex fulvovillosus. Truncus supra pube, densâ admodum, fulvo-aureâ tectus. Squamulce piceæ. Digiti articulo extimo apice dilatato. Abdomen segmento primo toto villoso-fulvescenti, antepenultimo margine pilis non fulvescentibus sed albidis tomentoso, ultimo supra carinato. Venter hirtus.

Var. $\beta$ corpore cinereo-villoso; trunco supra pube flavescenti; abdomine segmentis margine tomentoso-albis.

When my Synopsis Specierum went to the press, I had seen only variety $\beta$ of the male of this insect; but since that, in July last, I took recent. specimens of both sexes frequenting the flowers of Erica, in a sunny sand-pit near Combe Wood, a spot well known to the Entomologists of the Metropolis, and producing many very rare insects. As all that I was then able to examine agreed to- 
A PIS. (**. d. 2. $\left.\alpha_{\text {. }}\right)$

gether, I thought it most adviseable to correct my Nomen Specificum and description by them: the specimen from which I originally described being, probably, one that had been disclosed so long from the pupa, as to change the colour of its hirsuties. Panzer's figure, which evidently belongs to the male of our insect, was taken from one in the same predicament; and if I am right in my reference to Fabricius, concerning which, however, I have my doubts, his description was drawn from one of this sort too. Geoffroy for his, "Abeille à levre jaune et anneaux du ventre blanchâtres," which appears synonymous with this variety, refers to one described in the first edition of the Fauna Suecica, but which afterwards seems to have been omitted by Linneus. This, however, although it belongs, I think, to the present family, I suspect to be a different species, perhaps $A$. limaculata; for Linneus says of it: "Abdomen nigrum segmentis villosis canis 5 vel 6 ," which implies that not the margins only, but the whole of these segments was covered with hoary hairs. Geoffroy says of this Apis : "Cette espéce forme dans la terre des trous horizontaux qui sont fort longs et divisés au bout en plusieurs cellules. On voit ces trous dans les terreins coupés perpendiculairement en forme de $\operatorname{murs}(q)$." From an inspection of the female, of which I had seen no specimen, when I made the arrangement adopted in my synopsis, I find that $A$. rotundata

(4) Tom. 2. p. 413, 414 .

ought 
ought to follow $A$. bimaculata, which it resembles in many respects.

\section{A. Pallicincta. 67.}

Since the printing of my synopsis, I have again seen the insect which I had described under this name, and find it to be $M$. fodiens before noticed $(r)$. I drew my description of it long ago, before I was acquainted with the characters which distinguish my first family of Melitta, from a specimen, the only one I had then seen, in Mr. Drury's cabinet (s), the structure of whose proboscis I could not ascertain. As it seemed to have a general resemblance to some of the individuals of this family, particularly $A$. rotundata, I placed it next to that insect; although I observed even then that it wanted one of the most prominent characters of the subdivision, the os crassum. A year or two after this I took it myself, and finding its instrumenta cibaria to be those of a Melitta possessing peculiar characters, I did not recollect that it was the same insect I had described before as an Apis.

68. A. atra, albido-subvillosa; abdomine subglo-sulglobom boso.

MUS. D. Haworth.

Long. Corp. Lin. $4 \frac{2}{3}$.

Hab. In Angliâ. Hanc unicam vidi.

DESCR. Acul.

CORPUS atrum, pube cinereâ.
( $r$ Supr. p. 34, 35.
(s) Apis, n. 35. 
CAPU t atrum, immaculatum, pube albidâ. $V$ er. tex atro-pilosus.

Truncus supra hirsutie e pilis atris cinereisque mixtis constante notandus. Thorax posticè glabriusculus, punctatus. Squamula picex. Ala subhyalinæ, nervis nigris. Pedes cinereohirti.

Ав оомеN subglobosum, glabriusculum.

Obs. In hoc specimine margo segmentorum ab. dominalium forsan derasus.

I have seen a single specimen only of this insect: in which I suspect that the hair is rubbed off the margin of the dorsal segments of the abdomen; but supposing this to be the case, still it is sufficiently distinguised from $A$. rotundata, which it resembles, by its black nose and lip.

- retusa. 69. A. corpore femineo atro, hirsuto; tibiis posticis scopâ fulvo-aureâ :

corpore masculo nigro, hirsuto-fulvo; ana nigricanti, pedibus intermediis elongatis, crinito-pectinatis.

\section{ACUL.}

Apis retusa nigra, subhirta, abdominis basi retusâ, tibiis posticis extus lanatis.

Lin. Syst. Nat. Ed. 12. E Gmel. p. 2772. n.8. Fn, Suec, 1690.

Vill. Ent. Eur.3. n. 6.

Miill. Zool. Dan. n. 1898,

Ross. Fn. Etrusc. n. 907.

Apis accrvorum hirsuta atra, tibiis posticis ferrugineis: 
Fal. Ent. Syst. Em. n. 36.

Lin. Syst. Nat. ed. Gmel. p. 2783. n. 50.

Apis rufipes hirsuta, atra, pedibus posticis rufis.

Miller. int. not. Graian, supr. citat.

Bomlylius medius totus niger, lanugine duntaxat longâ

flavâ anteriori $\int$. inferiori superficiei primi crurum posteriorum internodii adnascente.

Rai. Hist. Ins. p. 247. n. 4.

Apis sylvestris muraria nigra.

Rai. Hist. Ins, p. 243 ?

FIG. Scheff. Icon. tab.77.fig. 5 .

Harris. Exp, tab. 38. fig. 7.

Apis acervorum. Panzer. Fn. Ins. Germ. Init. n. 78. tal. 18.

Donovan. Eng. Ins. tom. 3. tal. 108. fig. 2.

Apis rufipes. Christii Hymenopt. p. 132, tab. 9. fig. 1.

MUS. D. Smith Linnean, Marsham, Latham, Drury, Haworth, $\boldsymbol{M}{ }^{`}$ Léay, Sowerby, Trimmer, Lathbury, Kirly.

MIAS.

Apis pennipes pubescens subgrisea; pedibus secundariis elongatis crinito-pectinatis.

Lin. Not. MS. in Syst. Nat.

Forst. Cat. Brit. Ins. n.731. Apis, n. 25.

Apis pilipes grisea, pedibus intermediis fasciculatopilosis.

Fab. Ent. Syst. Em. n.54.

Lin. Syst. Nat. Ed. Gmel. p.27\%6. n. 80.

Vill. Ent. Eur. 3. n. 54.

Ross. Fn. Etrusc. 910. Mantiss. 311.

Apis plumipes hirsuta, pedum mediorum metatarsis scopâ atrâ, posticè pilis raris longis barbatis.

Schrank. Enum. Ins. Austr. $n 804$.

Apis Hispanica hirsuta flavescens, abomine apice nigro, pedibus intermediis fasciculato-pilosis.

Fal. Ent. Syst. Em. n. 10?

Lin. Syst. Nat. Ed. Gmel. p. 2784. n. 1 ?

v 4 
A P I S. (**. d. 2, «.)

Apis sylvestris corpore oblongo, supinâ thoracis, ct an, teriori abdominis parte pulchrè flavâ, caudâ nigrâ. Rai. Hist. Ins. p. 243.

FIG. Harris. Exp. tab. 40. fig. 14.

Apis pilipes. Christii Hymenopt. p. 131. tab.8. fig. 9. mal.

Panzer. Fn. Ins. Germ. Init. n.55. tal. 8.

Apis Hispanica. Ibid. tal. 6.

Apis plunipes. Pallas. Spicil. Zool.9. p.24. tal.1. fig. 14.

MUS. D. Marsham, Latham, Drury, McLeay, Haworth, Trimmer, Sowerly, Lathlury, Kirly.

Long. Corp. Lin. 7-8.

$\mathrm{Hal}$. Barhamiæ. In floribus tempore vernali frequens, mas feminæe assiduus comes, quam, dum nectar florum sugit, lretus circumvolat. Terris induratis, glareosis aut argillaceis, sectis verticaliter, nobiscum nidificant; interdum et in muris antiquis. "In muris et aggeribus unaquæque foramen sibi soli excavat ellipticum fætui excipiendo, in quibus pabulum eidem nutriendo reponit." Raius. "Sub vesperum quæri• tat apta parietum foramina ibique pernoctat," Rossius.

DESCR. Acul.

CORPUS totum atrum, hirsutum.

$\mathrm{C}_{\text {APUT }}$ subtriangulare. Labium pilis rufis barbatum. Antennia capitis longitudine, nigræ, Truncus. Squamula picex. Ala fuscescentes, nervis nigris. Pedes hirti, tibiis posticis extrorsum scopâ fulvâ. Plante item postic basi fulvo-aureo extus hirsutæ. Scopulce ferruginex. Femora cum digitis picea. Aв оOMEN ex ovato oblongum, hirsutum. $V e \eta_{z}$ ter çุnฺvexus, piceus. 
A PIS. (**. d. 2. «.)

Obs. Scopa tibice posterioris in adultioribus flavescit.

Maris Corpus subtus albido-villosum. Maxille apud basin maculà obliquâ flavâ notatæ. $L a-$ lium flavum margine omni, punctoque utrinque postico, atris. Nasus cum frontis angulis rufus, suturis nigris. Antenne nigræ, scapo antrorsum pallidè carneo. Gence barbâ longâ densâque albâ. Facies anticè pallido, posticè fulvo villosa, spatio inter antennas interjecto glabro, lineâ mediâ elevatiusculâ noțato. Truncus supra et utrinque hirsutie fulvâ mollissimâ vestitus. Squámulæe nigræ. Ale subhyalinæ. Pedes primarii cinereo-pilosuli, tibiarum apicibus extrorsum tomentoso-pallidis ; secundarii reliquis longiores, femoribus subtus nigricante-barbatis, tibiis hinc cinereociliatis, plantis elongatis, cinereo-pilosulis, antrorsum versus apicem penicillo denso pilorum nigrorum instructis $(t)$, posticè unà cum digitis, pilis longissimis, rarioribus crinitis $(u)$; digitorum articulo extimo utrinque densiùs barbato $(x)$; ternarii femoribus subtus nigro barbatis, tibiis nigro-villosis, posticè cinereofimbriatis, plantis brevibus, latis, posticè nigro longiùs pilosis. Scopulce nigræ, lineâ intermediâ pallidâ. Aldomen subglobosum, su-
(t) Tab. 11, d. 2, $\alpha . \beta$. fig. 18, $a$.
(x) Ibid. $c c$.
(u) Ibid. $b$. 
A PIS. (**. d. 2. a.)

pra hirsuto-fulvum, ano nigro-villoso. Ani nigritudo " non abruptè incipit, sed ipsa baseos flavedo quibusdam veluti umbris, penumbrisque in eam degenerat $(y)$. Venter apud anum depressus, lateribus villosoalbicantibus.

$\operatorname{Var} . \beta$ adultior, corpore supra hirsutie subgriseâ, vel cinerascenti vestito; naso flavo punctulis duobus nigris; antennis scapo antrorsum flavo; alias $\alpha$, ut ovum ovo, simillimus.

From an inspection of the authentic specimen preserved in the Linnean cabinet, I do not hesitate to give the aculcate of the present Apis as the genuine $A$. retusa of Linneus. That specimen is, indeed, smaller than our English ones usually are, not quite so hairy, nor is its hair of so deep a black; but these circumstances appear to be entirely accidental: insects of different climates, and sometimes those of the same, vary much in size; and the hair of an Apis newly disclosed from the pupa, as to colour and density, is often very different from that of the same individual when it has been long exposed to wind ard weather. In other respects the Linnean specimen is the very counterpart of ours, and agrees exactly with the description in the Fauna Suecica. "Magnitudine A. mellifica. Corpus totum nigrum pubescens. Tibia posticæ dilatatæ, extus vellere brevi, denso, flavo."

(y) Schrank. Enum. Ins. Austr. p. 399. 
This insect, however, has been mistaken by Fabricius and many other Entomologists, and confounded with another. As it is usually very hairy, this author regarded it as a Bombinatrix, and took it for granted that it could be no other than the $A$. acervorum, Linn. Possessed with this idea, he added to "hirsuta, atra," the Linnean definition, the terms "tibiis posticis ferrugineis," in which he has been followed by Gmelin and others. But had he paid due attention to the description of the Fauna Suecica, he would have been convinced that, by $A$. acervorum, Linneus intended a very different insect. "Præcedenti( $z)$ similis," says he, " sed minor: toto corpore nigro, immaculato exceptis setulis quibusdam circa collum sulphureis." These terms plainly exclude the tibiæ ferrugineæ of $A$ retusa, of which I never saw a specimen, and I have seen many, that had any sulphureous hairs about its neck. I suspect that the specimen preserved in the Linnean cabinet, as $A$. acervorum, is not the original one, although its label is an autograph of Linneus. When an insect with such a label answers to the description of Linneus, no doubt can remain of its authenticity; but when it varies from it, its claim to be considered as the original specimen is a good deal invalidated. In the present instance, the specimen differs from the description in several respects; its wings are violet, it has no sulphureous hairs about its neck, and

(z) Nempe A. lucorum, Linn, 
the disk of the scopa, or brush, which covers the underside of its abdomen, is tawny; it belongs to the same family with the Alcille maçonne of Reaumur $(a)$, and I strongly suspect it to be the female of that very insect, which that author describes in terms which agree well with it. "Les uns doivent devenir des abeilles très-noires, aussi noires, mais plus veluës que les perce-bois; elles ont seulement un peu de jaunâtre en-dessous à leur partie posterieure $(b)$." I shall give a fuller description of it in the margin $(c)$, Concluding that $A$. retusa was $A$. acervorum, and unacquainted with any insect that would agree with the Linnean character of the latter, Fabricius has excluded it from his last work, Entomologia Systematica Emendata et Auc$t a$, as a nonentity; expressing only a suspicion that it may possibly be his Andrena pilipes (d). With respect to other synonyms of the aculeate, the insect Christius has figured for $A$. retusa (e)

(a) Tom.6. tab. 7. fig. 1,2, 3. It belongs to the fourth subdivision, of the second section, of my family latio inflexo. (**. c. 2.8).

(b) Reaum. ubi supr. Mem. 3. p. 60.

(c) DESCR. Acul. Corpus atrum, hirsutum. Maxilla validæe, dilatatæ, apice extus bidentatæ, dente exteriori acuto. Ala corpore longiores atro-violascentes. Pedes atri, tarsis rufis. Aldomen subglobosum, atrum, undique hirsutum, ventris scopâ disco fulvo.

Long. Corp. Lin. 7.

(d) Melitta pilipes of this work, vid. supr. p. 97, 98.

(e) Hymenopt. p. 119. tab. 9. fig. 4. 
appears to be a Bombinatrix, and I think represents one that I shall hereafter describe: his $A$. rufipes is the true $A$. retusa. Under the same name Miller, in the MSS. so often quoted by me, has noticed our Apis; to his definition, inserted amongst the synonyms, he adds this short description. "Tibiæ tarsique postici rufo vellere extus hirsuti." Ray appears to have described this bee twice, but as this may seem too bold an assertion to hazard with respect to a writer of his acknowledged accuracy, I shall assign my reasons at large for being of that opinion. The description he gives of his Bombylius, n.4. so exactly suits our insect, that I think no one will deny them to be synonymous; the doubt will be attached to the other which I have quoted, viz. his $A$. sylvestris muraria nigra. His description of this, "Tota nigra est, corpore breviusculo, cruribus duntaxat postremis obscuro aurantii colore rubentibus," will suit our insect very well; but it is not so much upon this that I ground my opinion, as the following circumstance. This illustrious author informs us, that it makes its nest in walls and banks, and that it abounds at Kilby, near Hill Morton, in Northamptonshire $(f)$. Now, in the beginning of July, 1797, in company with Mr. Marsham, at Wandsford and Ufford, in the northern part of the same county, I discovered $A$. retusa in the greatest abundance, frequenting the walls made of the $(f)$ Hist. Ins. p. 243. 
stone of that country $(g)$ : a strong proof, as hig description agrees with ours, that we both mean the same insect. It is probable, that, in his travels, seeing this bee so plentiful about the walls, at the place above-mentioned, he took it for a different species from the one he had seen less frequent in other parts, and in a different situation. As some doubts, however, must still remain, without I could visit the very spot, where he found it, I have placed a query after this synonym.

The male of this Apis is so totally unlike the female, that it has been regarded by all authors, not excepting even Linneus himself, as a distinct species. In an interleaved edition of the Systema Naturæ, containing MS. notes of that great $\mathrm{Na}$ turalist, and now in the possession of the President of the Linnean Society, (who, with his accustomed liberality, has permitted me to copy such of them as relate to the present genus), I find it described under the name of $A$. pennipes, and placed next to Melitta cunicularia: upon the authority of Forster, it is said to be a native of North America: it is inserted, under the same name, in Forster's Catalogue of British Insects, published in 1770. Professor Pallas and Schrank, denominate it $A$. plumipes. Fabricius, and after him Panzer, call variety $\alpha, A$. Hispanica $(h)$; and variety $\beta, A$. pi-

(g) Kettering stone.

lipes.

(h) I am not quite certain that the A. Hispanica of Fabricius is synonymous with this; his dcscription agrees: but ours in

size 
lipes. When the insect first makes its appearance in the spring, the down of the upper side of the body, the anus excepted, is of a reddish yellow, answering to the description and figure of the former; later in the year, when it has been long disclosed, this becomes cinereous, or greyish, and then it agrees with those of the latter. I suspect A. cochlearipes of Christius to be a different species, for there are several that are distinguished by similar pedes secundarii, although Panzer has referred to it as synonymous with $A$. pilipes. It is singular that an insect should be described under so many different names, and prove at last to be entitled to none of them. This point I shall now endeavour to prove as briefly as possible. When I first set out in my entomological career, I began to notice the motions of this Apis, and have continued to do so occasionally ever since. Early in the spring the male may generally be seen attendant upon his swarthy bride, fluttering round her, or hovering over her, while she, with great coolness, collects the honey from flower to flower, without bestowing any attention upon him : if she departs, he departs; and if she returns, he returns likewise. During the season of courtship, his whole employ-

size is greatly smaller than $A$. virginica. Panzer's certainly belongs to ours. Linneus, in the MS. notes mentioned above, has described another $A$ pis under this name, which he received from Forster, in these terms: Hispanica A. nigra, abdomine testaceo apice nigro, segmentis duobus penultimis albis.

ment 
A.PIS. (**, d. 2, a.)

ment seems to be to attend upon her; but when the halcyon days of love are over, like many other husbands, he goes about his business, and leaves her to take her flights in solitude. I was often entertained with this scene, before I was aware of any connection betw'en these little creatures; but at length I could not help suspecting, in spite of the total want of resemblance between them, that they were different sexes of the same species: to ascertain this point, I examined anatomically a number of each; and found that the black ones were always aculeates, and the others as constantly males. I found both afterwards in the same nest, which has likewise been done, more than once, by my friends the Rev. Peter Lathbury, and Mr. James Trimmer. These circumstances furnish as strong presumptive evidence, in support of the fact I assert; short of sceing the sexes copulâ connexos, as can be desired. Ray, indeed, makes an observation with respect to the male, which seems, at first sight, to militate very strongly against the opinion here advanced: after describing it in terms which leave no doubt as to its being the same insect, he says: "In muris et aggeribus terrenis nidum pro fætu constituit prioris nido (viz. A. sylvestris muraria nigra) similem, in quem substantiam quandam dulcem melle crassiorem ei nutriendo recondit (i)." This, however, is casily accounted for; he would certainly never dream of any connection

(i) P. 243

between 
between two insects so entirely unlike each other, without he had noticed some circumstances that might excite such suspicion; and therefore, of course, if he observed the male go into a nest, he would immediately conclude that it was peculiar to it, and so, vice versâ, with respect to the female. What he says with regard to the two nests being similar to each other in form, and built in the same situation, is a further proof of this.

70. A. hirsuto-fulva; ano nigro; plantis interme-Haworth diis extrorsum barbatis.

MUS. D. Haworth, Davies.

Long. Corp. Lin. 7.

Hab. In Angliâ, rarissima.

DESCR. Mas.

CORPUS atrum, supra hirsuto-fulvum.

Caput hirsuto-pallidum. Maxilla nigræ, immaculatæ. Labium luteum, posticè utrinque puncto nigro. Nasus anticè pallidus, margine extimo nigro. Antenne nigræ, scapo antrorsum pallido.

Truncus. Thorax disco piloso-nigricanti. Pectus hirsutie pallida. Squamulce nigræ. Ale hyalinæ, nervis nigris. Pedes atri. Femora antica cinereo-barbata, posteriora quatuor nigro. Tilice secundi et tertii paris fulvo extus ciliatæ. Pedes secundarii posticis breviores, plantis pilis densis atris extrorsum fimbriatis. 
A PIS. (**. d. 2. «.)

Digitiomnes rufescentes, articulo extimo apice dilatato, piceo.

A в D OMEN atrum, pubescens, basi hirsuto-fulvum. In honorem D. Haworth, Generis Narcissus Monographi, Entomologiæ etiam studiosi, hanc Apem nominavi.

This species, at first sight, strongly resembles the male of the preceding; but upon a close inspection, we find that its intermediate legs, instead of being longer, are shorter than the posterior; their plantæ, also, have only a dense beard of black hairs on one side, without any of those very long ones, along the whole of the tarsus on the other, which form a remarkable character of the male sex of that insect. Its maxillæ, likewise, have no yellow spot; and the anterior part of the nose alone is pale yellow, and not the whole face below the antennæ. The specimen from which I drew my description, is in the Museum of Mr. Haworth; I have since seen it amongst the English insects of Major Gen. Davies at Blackheath. I have by me two or three other exotic males, whose intermediate legs resemble those of $A$. retusa and $A$. Haworthana, in being, what Fabricius terms, fasciculato-pilosi.

cyanea. 71. A. cæruleo-virens, glabriuscula, cylindrica; abdomine cuneiformi : ore masculo albo:

FIG. Acul, tal.17. fig.7. Mas. Ilid. fig.8. Apis carulea cxrulea, alis violaceo-fuscis. Vill. Ent. Eur. 3. n.89. tal. 8. fig. 25 ? 
A P IS. (**. d. 2. $\alpha$.)

MUS. Regina (k), D. Marsham, Kirly.

Long. Corp. Lin. $3-3 \frac{3}{4}$.

Hal. Barhamix. In floribus Jacolcea tempore atltumnali anni 1799 a me semel lecta.

DESCR. Acul.

CORPUS lineare, punctulatissimum, ex viridi cærulescens, glabriusculum, sub lente parvâ pube pallidâ pilosulum.

CAput. Proboscis valvulis incurvis $(l)$, laciniis interioribus linearibus $(m)$. Labium et Maxille nigra. Antennce capite breviores, clavatæ, piceo-nigræ, apicearticulo primo brevi, $\operatorname{conico}(n)$.

Truncus supra disco læviusculo, nitidissimo. Thorax lineolis quinque longitudinalibus levissimè impressis notatus. Squamul.e atræ. Alce fuscescentes, certo situ, apicem versus præcipuè, violascentes; nervis nigris. Pedes nigri, tibiis posticis scopâ parvâ pallidâ.

Ав Dомen cuneiforme $(0)$, segmentis anticis margine auctis, depressiusculis. Anus obtusus, mucrone parvo instructus. Venter reliquo corpore longiùs pilosus.

Maris Corpus violaceum. Labium et Nasus alba. Antennce desunt. Squamula piceæ. Abdomen segmento penultimo supra carinato apice mucronato, ultimo inflexo.

(k) The last row but one, the fourtecnth specimen from the left hand.

(l) Tab, 11, d. 2, a. fig. 9, $a$.

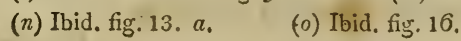

(m) Ibici. fig. 10. $a a$.

$\mathrm{x} 2$

This 
A PIS. (**, d. 2, $\alpha, \beta$.)

This little insect varies somewhat from the characters of the present family, for the valvulæ, instead of being strait, are incurved; and the interior lacinix are not pointed at their tips; in gene. ral habit, also, it is unlike the rest of the individuals that compose this section. It is, however, more nearly related to this, than any other family; for it exhibits the following characters, which combined are peculiar to it: its exterior palpi, namely, consist of six articulations, and its interior of two; not to mention that the nose and lip, of the male, are of a different colour from those of the other sex, a circumstance which usually distinguishes the insects of this section. $A$. cyanea approaches so near to $A$. carulea of Villers, that I strongly suspect it to be merely a variety of that insect; in that case it ought to be denominated by the name he has given it.

$$
\text { **. d. } 2 \text {. } \beta \text {. }
$$

iricolor. 72. A. violacea, supra glabra; alis nigricantibus.

FIG. Drury. Ins. vol. 1.p. 108. tol. 45. fg. 3.

Tal. 17. fig. 9 .

MUS. D. Latham, Drury Spec. exot. Kirly Spec, exot.

Long. Corp. Lin. 8.

Hab. In Angliâ? D. Latham. Ex insulâ Jamaicensi allatam accepit D. Drury.

DESCR. Acul.

CORPUS violaceum, supra glabrum. 
$\mathrm{C}_{\mathrm{A} \text { pur }}$ punctatum, atro-pilosum. Gence barbatæ. Antennce capitis ferè longitudine, nigræ, subtus pallidæ.

Truncus. Thorax glaber, nitidissimus, iricolor, lineâ longitudinali intermediâ impressus, punctatus disco lævissimo. Metathorax et Pectus atro-pubescentia. Squamule violaceæ. Ale fusco-nigræ. Pedes violacei, atro-hirti. Plantee atræ, undique hirsutissimæ. Digiti picei.

Авдомеn subiricolor, latum, supra glabrum, punctulatum. Anus fimbriâ atrâ. Venter anum versus atro-hirtus.

This most beautiful insect is in Dr. Latham's cabinet, amongst his English Apes, but he does not recollect where it was taken, or upon what authority he considers it as English(o). It has been received from Jamaica by Mr. Drury, who has given an excellent figure of it, of which I was not aware when I caused it to be engraved for this work. I have also received it from Mr. Marsham. Its place ought to be next to $A$. violacea, Linn. which it a good deal resembles, except that, instead of black, its body is violet; and, on the contrary, the wings, instead of violet, are black. The prismatic hues upon the thorax are very brilliant; upon the abdomen they are much fainter. Since I wrote the natural character of this section, I find that the interior lacinix, of the insects that belong to it, are lineari-lanceolate, and shorter than the exterior.

(o) Vid. supr, vol, 1. p. 191. 
mellifica. 73. A. corpore femineo pubescenti; thorace subgriseo; abdomine elongato, conico; alis corpore dimidio brevioribus; tarsis rufescentibus: corpore neutro pubescenti; thorace subgriseo; abdomine subprismatico; plantis posticis intus transversè striatis:

corpore masculo pubescenti; trunco tomentoso-fulvescenti; oculis posticè conniventibus; alis corpore longioribus.

Apis mellifica pubescens, thorace subgriseo, abdomine fusco, tibiis posticis ciliatis, intus transversè striatis. Lin. Syst. Nat. Ed. 12. E Gmel. p. 2774. n.22. Fn, Suec, 1697.

Fal. Ent. Syst. Em. n. 58.

Vill. Ent. Eur. 3. n. 18.

Scop. Ent. Car. n. 811.

Schrank. Enum. Ins. Austr. $n 813$.

Miill. Zool. Dan. n. 1907.

Bergman. Act. Upsal. 1779.p. 310.

Ross. Fn. Etrusc. n. 912.

Forst. Cat. Brit. Ins. n. 719. Apis, n. 9.

Apis cerifera. Scop. Ann. Hist. Nat. 4. p. 16. n. 16. Apis gregaria. Geoffr. Hist. Ins. 2. p.407.n. 1.

Apis mellifera. Fourcroy. Ent. Par. n. 1.

Aldrovand. Ins. n. 20.

Apis domestica seu vulgaris alvearium. Rai. Hist. Ins, p. 240.

FIG. Mouffet, Ins.p. 1.

Jonst. Ins. 1. tab. 2,

Swammerdam. Bil. Nat. tal. 17. jig. 1, 3. Operaria, 3, Femina, 4, Mas.

Reaum, tom. 5. tal.22. fig. 1, Operaria. 2, Mas. 4, Femina, 
Femina. tab. 25. fig. 1, Operaria. 10, Mas. 16, 17, Femina.

Christii Hymenopt. tal. 1. fig. 1, Operaria. tal. 2. fig. 1, Mas. 5, Femina.

Harris. Exp. Eng. Ins. tal. 39. fig.9, Operaria. 10, Mas.

Sulx. Ins. tab. 19. fig. 123.

Tab.17. fig. 10, Femina, 11, Mas. 12, Operaria.

MUS. Femina, Kirly. Operaria museis ferè omnilus hospitatur, Mas, D. Marsham, $M^{\mathrm{c}}$ Leay, Kirly, \&c.

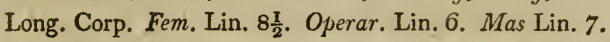

Hab. In Angliâ. Inculta in arboribus cavis nidificat, sed rarissimè obvia, a $\mathrm{D}$. Sowerby semel detecta; frequentiùs culta hospitatur. REGINA (Femina) unica. Fuci (Mares) ad 1600. Operarie (Spadones) ad 20,000. Respublica Alvearii gynæcocratica est, dum Femina imperans semper inclusa, operariorum custodum satellitio assiduè stipata, antennis obvium marem salutat, insiliendoque comprimit cum illius vitâ dispendio ; parit dein ova ad 40,000 sæpe quotannis, in adaptatis favi cellis; his exclusis gradu secundo supra calorem æstatis consuetum adolescunt Larvæ sextiduo, nent ad parietes ccllas, operiuntur usque dum adultæ evolant, alteroque die mellificant. Harum femina junior, per triduum omni horæ quadrante, stridorem edit, eoque admonet emigraturum in examina gregem. Mares ignavum pecus, incurii apricantur serenis diebus, gulæ dediti. Spadones operarii, neutri, indefessi, mel e nectare, ceram e polline florum $(p)$ scdulò legunt $\frac{1}{4}$ nilliaris spatio, quoties per cælum licet, reducunt, favos cereos struunt sexangulari-prismaticos, eosque melle replent, fominam mares pullosque nutriunt, cellas inhabitatas repurgant, mirâ munditiâ impura auferunt, vigilias et

(p) Hoc tamen negatur a D. Huber. 
A P IS. (**. e. 1.)

stationes ad portas instituunt, hostes arcent aculel ic. tu, maresque demum transactis nuptiis occidunt, expellunt. Examinant emittendo colonias feminâ duce ad novas quærendas sedes superato solstitio æstivo. Hostes imprimis sunt Myrmecophaga, Mures, Ursus Arctos, Viverra Ratel, Motacilla alla, Merops Apiaster, Cuculus indicator, Picus viridis, Falco apivorus, Pavones, Hirundines, Bufones, Phalana mellonella, cereana, E'c. Apes fures, Vespa, Pediculi, Aranea calycina, fumus, frigus intempestivum, \&c. Tulipe flores captivant. Flores melliferi non omnes, præcipui sunt Tetradynamia, Echii, Boraginis, Verbasci, Scrpylli, (Falia, Salicis, Aceris, Ruli), \&c. imprimis Erica Suecis et Lunebergensibus, Fagopyrum Scanis, Tilia Polonis, Rosmarinus Narbonensibus, Thymus Atticis, Arbutus Corsis, Alsinthium Sardis, Aconitum Ponticis, (Rulus Anglis), \&c. hinc pretium varium mellis. Pan Apum vestitur a D.D. J. O. Hagstrom; historiam apum aut culturam dederunt Reaumur, Aubenton, de la Pluche, Albrecht, Riem, Huber, Wildman aliique

_-ipsæ Regem parvosque Quirites

Sufficiunt, aulasque et cerea regna refigunt,

Lin. Syst. Nat. Ed. Gmel.

\section{DESCR. Fem,}

CORPUS fusco-nigrum, grisescente-pubescens, Cafut depresssum. Maxilla sordidè rufæ, apice bidentatæ, dente exteriori longiore acuto. intus concavo, interiori truncato segmento circuli dempto $(q)$. Labium rufescens. Oculorum pili, certo situ, aurei. Antennce piceæ, pellucidæ, subtus pallidiores. Facies inæqualis, Vertex nigricanti-villosus.

(q) Tab. 12. c. 1. fem. fig. 4, 5 .

Truncus 


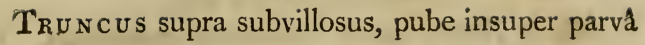
pallidè aureâ, certo situ, micans. Thorax lineolâ intermediâ longitudinali posticè abbreviatâ exaratus. Scutellum prominens. Squamulce piceæ. Ala abdomine dimidio breviores, subtestaceæ; nervis rufis, costâ piceâ. $P$ edes piceo-nigri, griseo-villosi, geniculis tarsisque rufis. Plante posteriores apice segmento circuli dempto, Scopulce auratæ, pilis brevissimis,

Ав оомen glabrum, a latere conspectum pilis brevissimis decumbentibus pallidè aureis sericeum, segmento primo brevi, pubescente, omnibus apice rufescentibus. Venter sordidè rufus, subpubescens, segmento ultimo nigro. Neutri Maxillce nigræ, intus lineis duabus elevatis notatæ $(r)$. Antennce nigræ, opacæ. Thorax densiùs pubescens. Metathorax villosoflavescens. Squamula nigræ. Ala subhyalinæ. Pedes nigri. Tibice posticæ supra inæquales longitudinaliter hịnc concavæ, subtus tomentosæ. Planté posteriores supra lineâ longitudinali elevatiusculâ, extus pilis flavescentibus ciliatæ. Scopulce auratæ, fulvæ. Digiti rufo-picei. Abdomen ex oblongo cordatum, segmentis duobus anticis pubescentibus, tribus proximis basi fasciâ tomentoso-pallidâ. Anus pube nigricanti subvillosus. Venter pubescens, basi sordide fulvus.

(r) Tab. 12. e. 1. neut fig. 10, 11 , 
Maris Corpus densè tomentoso-grisescens. Os hirsutissimum. Maxill $\mathfrak{c}$ valdè barbatæ apice bidentatæ, dente exteriori acuto, interiori truncato $(s)$, sub hirsutie oris penitus occultatæ. Labium rufum. Oculi maximi, ovati, pilosissimi, locum occipitis occupantes, ubi confluunt $(t)$. Stemmata in angulum frontis, paulò infra concursum oculorum, $\operatorname{sita}(u) . A n$ tennæe nigro-piceæ, opacæ, nitidæ. Truncus supra tomento sordidè fulvescenti, brevi mollis. Scutellum et Metathorax longiùs villosa. Squamulce nigræ. Alce magnæ, corpore longiores, hyalinæ; nervis testaceis costâ ferrugineâ. Femora quatuor anteriora hirsutissima. Pedes posteriores clavati, elongati $(x)$, supra glabri. Tivia Plantaque posticæ compresso-trigona, subtus hinc tomentoso-pallida. Scopularum pili breves, ferruginei. Abdomen basi hirsutulum, segmentis margine decoloribus. Anus subinflexus, pubescens. Venter pallidus, hirsutus.

My Synopsis Specierum was printed before I was aware that there were other species, besides $A$. mellifica, belonging to this section, and all distinguished by "Plantæ posticæ intus transversè striatæ;" otherwise I should have excluded this character from my definition of the neuter.

(s) Tab. 11.**. e. 1. fig. 3.

(u) Ibid. $6 . \quad(x)$ Ibid. fig. 8.

(t) Ibid, fig. 2. ac. 
APIS. (**. e. 2.)

**. e. 2 .

74. A. hirsuto-flavescens; thorace fulvo,

Musco. .

run.

Apis Muscorum hirsuta, fulva; abdomine flavo.

Lin. Syst. Nat. Ed. 12. E Gmel.p. 2782. n.46. Fn.

Suec. 1714.

Fal. Ent. Syst. Em. n. 31.

Vill. Ent. Eur. 3. n. 100.

Schrank. Enum. Ins. Austr. n. 801.

Fn. Frid. $n, 652$.

Miill. Zool. Dan. n. 1924.

Ross. Fn. Etrusc. 2, n.904.

Forst. Cat. Brit. Ins. n.728. Apis, n. 22.

Bombylius medius, dorso longis et densis pilis rufis ves. tito, mellificus vulgatissimus, in gramine nidum construens.

Rai. Hist. Ins. p. 246. n. 3.

Apis senilis hirsuta cinerea.

Fal. Ent. Syst. Em. n. 44.

Lin. Syst. Nat. Ed. Gmel.p. 2784. n. 117.

Vill, Ent. Eur. 3. n. 113.

FIG. Reaum, tom. 6. Mem. 1. p.32. tab.2. fig.1-3.

Buxin. Abregé. tal. 6. fig. 1-3.

Frisch. Ins. 9. tab. 26. fig. 8.

Schaffer. Icon. tab. 69. fig. 8.

Christii Hymenopt. Femina, p. 130. tal. 8. fig. 3. Operaria, p. 142. tab. 11. fig. 8.

Harris. Exp. Eng. Ins, tab.38. fig.6. tal.40. fig.17, 18.

MUS. D. Smith Linnean, Banks Mas var. $\gamma$, Marsham, Latham, Haworth, Trimmer, Lathbury, McLeay, Sowerly, Kirly.

Long. Corp. Lin. 5-10.

Hab. Barhamiæ: In pratis et graminosis frequentisa sima, In terræ cavitatibus e musco nidum struit.

DESCR. 
DESCR. Acul.

CORPUS hirsutie pallidè flavâ.

Caput. Os ferrugineo-barbatum. Proboscis trunci longitudine, palpis exterioribus acutis.

Truncus. Thorax hirsutie rufo-fulva, $\int$. aurantiacâ, tectus. Squamulae rufo-piceæ. Alae subcoloratæ, apice nervisque nigris. Pedes nigri, hirti. Femora densè flavido-barbata. Corbicula flavescens. Scopula ferrugineæ. Spinula castaneæ. Digiti picei.

Ав оммеN triangulare, supra hirsuto-fulvo-flavum.

$V a r . \beta$ minor; thoracis hirsutie dilutiori; alis coloratis, apice immaculatis; abdomine brevi, subgloboso. An eadem ?

$\gamma$ præcedenti similis, sed minor; abdomine triangulari.

$\delta$ thoracis hirsutie fuscâ, qui color ex pilis nigris fulvisque mixtis exoritur ; magnitudine præcedentem æquiparat. $\varepsilon$ præcedentibus dimidio minor.

Maris Maxille supra pallidæ, barbâ nigricanti. Antennce thoracis ferè longitudine, articulis subarcuatis. Scopula fusco-nigræ. Abdomen angustius, ani extremitate nigro-villosâ.

$V$ Var. $\beta$ tertiâ parte minor; spinulis atris; scopulis pallidioribus, vix auratis.

$\gamma$ adultior, corpore toto hirsuto-cinerascenti.

Obs. In hấc varietate thorax paululìm flavescit. 
APIS. (**. e. 2.)

Of these varieties I take $\alpha$ to be the female; $\gamma$ and $\delta$ to be the neuters of the largest $\operatorname{size}(y)$; and $\varepsilon$ the small neuter; $\beta$ I suspect may be a distinct species, in size it is intermediate between $\alpha$ and $\boldsymbol{\gamma}$. Variety $\beta$, of the male, is considerably less than $\alpha$, but it differs from it very slightly in other respects; it may be the male of variety $\beta$ of the other sex, but both are too similar to the rest to be separated, without a nest could be found, which contained them alone. Variety $\gamma$, of the male, is $A$. senilis of Fabricius, as appears by the specimen in Sir J. Banks's cabinet, which he labelled. The cinereous hue of its hirsuties is merely occasioned by age; the thorax, even in this, retains a tinge, very faint indeed, of its original colour.

75. A. hirsuto-cinerascens; thorace, abdomineque, Francil- . fulvis.

Bombylius mediæ magnitudinis, toto corpore, tam thorace quam abdomine, sordidè rufo.

Rai. Hist. Ins. p. 248, n. 13.

FIG. Tab. 17. fig. 13.

MUS. D. Marsham, Latham, McLeay, Haworth, Trimmer, Lathbury, Kirly.

Long. Corp. Lin. $4-5$.

Hal. Barhamiæ, præcedenti rarior.

DESCR. Acul.

CORPUS hirsuto-cinereum.

$\mathrm{C}_{\mathrm{APU}} \mathrm{T}$ atro-subhirsutum. $\mathrm{Os}$ barbâ rufâ. Pro-

(y) Reaum. tom. 6. Pref. p. 5.

loscis 
loscis capite longior. Facies circa basin antènnarum cinereo-villosa.

Truxcus supra hirsuto-fulrus. Squamulc testacex. Ala subcoloratæ, apice obscuriores, nervis ferrugineis costâ nigrâ. Pedes atrohirti. Femora barbâ cinerascenti. Tilia posticæe corbiculâ atrâ. Scopulıe fusco-nigræ. Spinulce nigræ. Digiti rufo-picei.

Ав Dомеr subglobosum, supra hirsuto-fulvum, basi penicillo pilorum cinerascentium utrinque ornatum.

Var. $\beta$ minor; scopulis vix auratis; abdomine fasciâ obscurâ nigricanti.

D. Francillon, cujus museum ditissimum stupendos insectorum thesauros, item quamplurimorum dilineationes accuratissimas exhilet, hoc insectum nomine insignitur.

This insect would by many be placed aside as a variety merely of the preceding, which indeed, at first sight, it resembles much; a close inspection will, however, convince the skilful entomologist that it is distinct. The hair of its head, except what grows round the base of the antennæ, is black, as is also the corbicula of the posterior tibia; the abdomen is of a different form, and its hair is of the same colour with that of the thorax, not to mention slighter differences; besides, which I think is a strong argument, its smallest neuter is less than that of $A$. muscorum; so that were this admitted to belong to that species, it would have neuters of three different magnitudes. 
76. A. hirsuto-flavescens; thorace fulvo; abdo-floralis. mine maculis, fasciisque atris.

Atis fasciata tota rufa, abdominis fasciis quatuor vel quinque nigris.

Scop. Ann. Hist. Nat. 4. p. 12, n.7.

Apis floralis. Lin. Syst. Nat. ed. Gmel. p. 2785.n. 125.

FIG. Harris. Exp. Eng. Ins tab.40. fig. 13. Acul.

Tab. 17. fig. 14. Mas.

MUS. D. Marsham, Latham, M`Leay, Haworth, Lathlury, Trimmer, Kirly.

Long. Corp. Lin. 6-8.

$\mathrm{Hab}$. Barhamix, in floribus frequens.

DESCR. Acul.

CORPUS hirsuto-flavescens.

CAPUT atro-subhirsutum, sed circa basin antennarum pili succrescunt cinerei. Proloscis vix thoracis longitudine, palpis exterioribus acutis. Os rufo-barbatum.

Truscus supra hirsutie rufo-fulvâ tectus. Squamulce ferruginex. Alæe subhyalinæ, apice obscuriores; nervis nigricantibus. Pedes atri, hirti. Femora barbâ pallidâ. Spinulae castaneæ. Corlicula atra. Scopula ferruginex. Digiti rufo-picei.

Aв DOMEY subtriangulare, supra hirsutie e fulvoflavescenti, segmento primo utrinque penicillo villorum flavidorum ornato, secundo maculis duabus lateralibus, proximis tribus fasciâ, atrohirsutis.

Var. \& abdomine hirsuto-fulro, segmentis qua- 
APIS. (**. e. 2.)

tuor intermediis utrinque maculâ hirsutâA atrâ.

Maris Caput hirsuto-flavescens pilis sparsis, atris. Antenne thoracis longitudine, articulis subarcuatis. Abdomen fasclis quatuor atris.

Sowerli- 77. A. hirsuto-flavescens; thorace, anoque, fulvis; ana. abdomine fasciis duabus nigris.

MUS. Kirby.

Long. Corp. Lin. 6.

Hal. Barhamiæ, semel lecta.

DESCR. Mas.

CORPUS hirsuto-flavescens.

CAPUT pilis atris inter hirsutiem subflavam sparsis. Maxilla supra pallidæ, barbâ nigricanti. Proboscis vix thoracis longitudine.

Truncus supra hirsuto-fulvus. Squamula testaceæ. Alce subhyalinæ, apice obscuriores, nervis nigris. Pedes atro-hirti, femorum barbâ flavescenti. Spinulce castaneæ. Scopule ferrugineæ. Digiti rufo-picei.

Ав DOMEN subtriangulare, supra hirsutie subflavâ, segmento tertio quartoque fascià mediâ, angustâ, hirsutâ, atrâ. Anus hirsuto-rufus extremitate nigro-villosâ.

D. Sowerby, Botanici periti, insectorum, atque rerum onnium naturalium, imprimis $\mathrm{M}$. Britanniæ indigenarum, collectoris indefessi, item pictoris eximii, hoc insectum nomen gerit. 
Its red anus sufficiently distinguishes this from the male of the preceding species, which in many respects it resembles a good deal.

78. A. hirsuto-pallida; thorace anoque fulvis; ab- Beckwitha domine fasciâ mediâ atrâ.

MUS. D. Marsham, Latham, Haworth, McLeay, Lathbury, Trimmer, Kirby.

Long. Corp. Lin. $4 \frac{\mathrm{I}}{2}-\mathrm{S}$.

Hal. Barhamix, in floribus satis frequens.

DESCR. Acul.

CORPUS hirsuto-pallidum, $\int$. pallidè flavum.

CAPUT atro-subhirsutum, ast circa basin antennarum villi pallidi innascuntur. Os barbâ ferrugineâ. Proboscis capite longior.

TRU N C s supra hirsutie rufo-fulvâ tectus. Squamulse ferrugineæ. Alce coloratæ, apice nervisque nigricantibus. Pedes atro-hirti, femorum barbâ pallidè flavâ. Spinula castaneæ. Scopula ferrugineæ. Digiti rufo-picei.

Aвдомen triangulare, segmento primo utrinque penicillo villorum flavescentium notando, secundo basi hirsuto-rufo, margine tertioque atro-hirsutis. Ani hirsuties rufo-fulva.

$V$ ar. $\beta$ dimidio minor.

Maris Caput hirsuto-flavescens, pilis atris sparsis succrescentibus. Maxillce supra pallidæ. Antenne thorace breviores, articulis subarcuatis. Alce apice immaculatæ. Scopulce fusconigræ. Anus extremitate nigro-villosus. 
A PIS. (**. e. 2.)

$V$ ar. $\beta$ duplo minor; digitis ferrugineis.

Obs. In utriusque sexús adultioribus thoracis et ani hirsuties cinerascit.

Memoric D. Beckwith Angli, Entomologi peritissimi, hoc insectun consecratur.

This insect very much resembles $A$. floralis, but instead of four narrow ones, the abdomen is distinguished by one broad black band only; as each of these has, likewise, a male agreeing with it, I think I am justified in considering them as distinct species. Variety $\beta$ of this sex is not half the size of a. I have observed not seldom a variation in the size of individuals of this sex, which leads me to suspect that, in each nest, there may be two descriptions of males as well as of neuters.

- Curtis- 79. A. hirsuto-pallida; thorace fulvo; abdomine atro, basi rufescenti.

MUS. D. NIarsham, Kirly.

Long. Corp. Lin. $4 \frac{1}{2}-5 \frac{1}{2}$.

Hal. Barhamiæ, cum præcedentibus, sed rarior.

DESCR. Mas.

CORPUS hirsuto-pallidum.

CAFU thirsuto-flavescens, immistis pilis sparsis atris. Maxille supra pallidæ. Antenne thoracis ferè longitudine, articulis subarcuatis.

Truncus supra hirsuto-fulvus. Squamule ferrugineæ. Ala subcoloratæ, apice obscuriores; nervis' ferrugineis, costâ piceâ. Pedes atro-hirti, femorum barbâ pallidâ. Tilice apice obscurè 
obscurè tomentoso-pallidæ. Scopulce fusconigræ, vix auratæ. Spinule castaneæ. Digiti picei.

Ав DомеN hirsutum, atrum, basis hirsutie obscurè rufâ.

Var. $\beta$ dimidio minor.

Memorice Floræ Londinensis celeverrimi auctoris, D. Curtis, Botanici summi, et inter entomologos haud ulli secundi, sit hac Apis sacra.

80. A. hirsuto-albida; thoracis fulvescentis basi, Forster- , abdominisque fasciis obscuris, nigricantibus.

MUS. D. Marsham, Kirly.

Long. Corp. Lin. $4 \frac{3}{4}$.

$\mathrm{Hal}$. Barhamiæ, cum precedentibus in floribus obvia.

DESCR. Acul.

CORPUS hirsuto-albidum.

CAPUT atro-subhirsutum. Os barbâ ferrugineâ. Truncus supra hirsuto-fulvescens. Thorax anticè hirsutie nigricanti. Squamulc ferrugineæ. Alce coloratæ, apice obscuriores; nervis ferrugineis, costâ piceâ. Pedes atro-hirti. Spinulce castaneæ. Scopulce fusco-nigræ. Digiti ferruginei.

АвдомеN subglobosum, hirsuto-cinerascens, fasciis tribus, obscuris, nigricantibus. Sit hoc insectum sacrum memoria D. J.R. Forster, qui inter alia studia plurimìm Entomolo. gia se dedit, et lumine novo eam illustravit. 
agrorum. 81. A. atra, hirsuta; thorace, anoque, ferrugineis. Apis agrorum hirsuta, atra, thorace toto anoque ferrugineis.

Fal. Ent. Syst. Em, n. 29.

Lin. Syst. Nat. ed. Gmel. p. 2782, n. 109.

Iill. Ent. Lur. 3. n. 117.

MUS. D. Banks.

Long. Corp. Lin. 7.

Hab. In Anglia, rarissima.

DESCR. Acul.

CORPUS atrum, hirsutum.

CAPU T immaculatum.

Truncus supra hirsutie ferrugineo-rufâ tectus. Ala coloratæ, apice obscuriores, nervis nigricantibus. Pedes atro-hirti.

АвDOMEN hirsutum, atrum, hirsutie basis obscurè rufâ. Anus ferrugineo-rufus.

This insect agrees very well with the description of Fabricius in every respect, except that it will not answer the epithet "magna." It may be a neuter.

. sylvarum.82. A. hirsuto-pallida; thorace inter alas, abdomineque fasciis, nigris, ano rufescenti.

Apis sylvarum hirsuta, pallida, thoracis fascià nigrâ, ano rubro.

Lin. Syst. Nat. Ed. 12. n.45. Fn. Suec, 1713.

Scop. Ent. Car. n. 822.

Vill. Ent. Eur. 3. n. 99.

Apis sylvarum, hirsuta pallida, thoracis fasciâ, abdomineque posticè nigris, ano rufo.

Fal. Ent. Syst. Em. n. 27.

Lin, 
A PIS. (**. e. 2.)

Lin. Syst. Nat. Ed. Gmel. p. 2782. n. 45.

Bombylius minor, lanugine albicante vestitus, caudâ rufescente.

Rai. Hist. Ins. p. 247. n. 9 ?

FIG. Apis scylla. Christii Hymenopt. p. 129. tab. 8. fig. 1.

Barbut. Gen. Insect. tal. 15. Apis, fig. 4, 5 ?

Tab. 17. fig. 15, fem. ibid. fig. 16, mas.

MUS. D. Smith Linnean, Marsham, Latham, $M^{\star}$ Leay, Haworth, Lathbury, Trimmer, Sowerby, Kirly.

Long. Corp. Lin. $4 \frac{1}{2}-7 \frac{1}{2}$.

$\mathrm{Hab}$. Barhamiæ, in floribus tempore autumnali frequentissima,

DESCR. Acul.

CORPUS hirsuto-pallidum.

CAPU T flavescente-subhirsutum. Os barbâ ferrugineâ. Proboscis vix thoracis longitudine, palpis exterioribus acutis. Vertex atro-pilosus.

Truncus supra limbo hirsuto-flavescenti, disco nigro. Squamule piceæ. Alce subcoloratæ, apice nervisque nigris. Pedey pallido-hirti. Apophyses secundariæ articulo extimo subtus insuper pube obscurè ferrugineâ mollis. Spinulce castaneæ. Corlicula pallida. Scopulce ferrugineæ. Digiti rufo-picei.

Ав домеN triangulare, segmento primo villorum . pallido-flavescentium penicillo magno utrinque insignito; secundo hirsuto, pallido, utrinque maculâ atrâ, tertio atro margine pallido. Anus fasciis hirsutis, pallidis rufisque alternis, variegatus. Segmentum ultimum ferrugineo subtomentosum. 
APIS. (**. e. 2.)

Var. $\beta$ dimidio minor; spinulis nigricantibus; abdomine segmento secundo maculis nigris lateralibus obsoletis.

$\gamma$ prxecdenti dimidio minor; abdomine seginento secundo immaculato, hirsutie obscurè fulvâ tecto, proximis duobus basi hirsutis, atris.

$\delta$ abdomine fasciâ unicâ hirsutâ atrâ, alias $\gamma$ simillima, et ejusdem magnitudinis.

$\varepsilon$ præcedenti minor, aliàs simillima.

Obs. In hac saltem varietate, si non in reliquis, in adultiorilus, corporis toti hirsuties fit cinerea, etiam ani; trunci disco, abdominisque fasciâ mediâ, hirsutis, atris. In omnilus apophyses secundarice articulo secundo subtus, vel potiis antrorsum, tomentoso-ferrugineo, sed hoc tomentum sub hirsutie longiori pallidâ plerumque delitescit.

Maris Maxillce barbâ rufescenti. Antennce thoracis ferè longitudine, articulis subarcuatis. Spinula nigrx. Scopule dilutiores. Aldomen segmento secundo quartoque fasciâ atrâ.

Íar. $\beta$ abdomine fasciâ atrâ unicâ.

The insect I have just described is the genuine A. sylvarum of Linneus, as appears from the authentic specimen, but it is not the $A$. sylziarum of Schrank and Rossi, which we shall shortly notice; A. Scylla of Christius seems intended for it, although his figure, if so, is very inaccurately coloured. It is rather doubtful whether this be the insect 
APIS. (**. e. 2.)

insect Ray meant by his Bombylius, n. 9, although I think that most probably it is; his description is too short to enable me to determine with certainty. Linneus has expressed the colour of the anus of this bee by the term ruber, and Fabricius by rufus, but it really exhibits alternate fasciæ of rufous and pallid, a mixture of colours which Linneus, upon some occasions, denominates griseus(z). The reader will observe that $\beta, \gamma$, and $\varepsilon$, varieties of the neuter, differ from each other in size, which will give three dimensions of that sex ; may not $\delta$ and $\varepsilon$, which, except in that respect, are exactly similar, belong to a distinct species ?

83. A. supra hirsuto-flava; thoracis fasciâ atrâ. fragrans. .

Apis fragrans hirsuta flava, thorace fasciâ nigrâ.

Pallas. It. 1. p. 474. n. 75.

Lin. Syst. Nat. Ed. Gmel. p. 2783, n. 111.

Apis pratorum. Fal. Ent. Syst. Em. n. 34.

Vill. Ent. Eur. 3. n. 111.

MUS. D. Marsham, Trimmer, Lathlury, Kirly.

Long. Corp. Lin. 8.

Hab. Barhamiæ, in floribus tempore autumnali, sed rara. Recens insectum odore rosarum flagrans.

DESCR. Mas.

CORPUS supra hirsutie densâ flavâ, subtus rariore pallidâ tectum.

Carut hirsuto-nigricans. Proboscis vix thorace longior, palpis exterioribus acutis. Maxillke barbâ nigrâ. Frontem penicillus villorum

(z) For instance in the description of Silpha grisea.

flaves- 
flavescentium ante antennas signat. Occipus hirsutie flavâ. Antenna thoracis longitudine, articulis subarcuatis.

Truncus. Thorax fasciâ hirsutâ inter alas atrâ. Pleurce flavo-hirsutæ. Squamule nigræ. Alce subhyalinx, apice paulò obscuriores, nervis ferrugineis, crassioribus nigris. Pedes atri, hirti. Femora hirsuto-cinerea. Spinulce castaneæ. Scopulce ferrugineæ. Digiti rufi.

$\Lambda$ в DOMEN oblongum, hirsutie densâ viridi-flavâ vestitum.

This insect is beyond a doubt $A$. fragrans of Professor Pallas, which Fabricius, for what reason I cannot conjecture, has called $A$.pratorum, giving the name of $A$. arbustorum to that which he mistook for the Linnean $A$. pratorum. Pallas says, "fæminæ odore roseo flagrantissimæ." I have never met with a female or ncuter; but the male, which with us is now and then to be met with in the autumn, has the same agreeable scent.

- Latreill-84. A. supra hirsuto-flava; thorace inter alas, abella. domineque fasciis duabus, atris.

FIG. Apis Maura. Christii Hymenopt. p. 131. tal. 8. fig. 8 ? MUS. D. Marsham, Trimmer, Lathbury, Kirly.

\section{Long. Corp. Lin. $7 \frac{1}{2}$.}

Hab. Barhamiæ. In Carduis, præcedente frequentior, roseum odorem spargens.

DESCR. Mas.

CORPUS supra hirsutie șubflarâ, subtus cinereâ, tectum. 
CAPUT atrum, subhirsutum. Maxilla barbâ nigricanti. Frons ante antennas fasciculo villorum pallido insignita. Antennce thorace breviores, articulis subarcuatis.

Truncus. Thorax anticè pilis fulvo-flavis densiùs hirsutus, posticè atris rariùs. Scutellum flavescenti-subhirsutum. Squamule picex. Alce subhyalinæ, apice paulò obscuriores, nervis nigricantibus. Pedes atri, hirti, femorum barbâ pallidâ. Spinulce nigræ. Scopulce et Digiti ferruginea.

AвDомen triangulare, supra hirsuto-flavescens, segmento secundo tertioque fasciâ atrâ.

In honorem D. Latreille Galli, in entomologiâ doctissimi, operis ingeniosissimi, quod characteres insectorum novos tradit, auctoris.

A. Latreillella is not unlike the preceding insect, and has the same remarkable scent of roses; but it is also a male, is smaller, its abdomen is of a different form, and is distinguished by two narrow black bands, which are scarcely separated by a few pale yellow hairs; these circumstances furnish a sufficient warrant for my colisidering it as distinct. A. maura of Christius comes very near to this, if it be not altogether the same.

85. A: supra hirsuto-flava; thorace inter alas, ab-Rossiclla. .

ᄀ dominisque fasciâ, atris.

Apis sylvarum hirsuta pallida, thoracis fasciâ nigra; abdomine basi nigro.

Schrank. 
Schrank. Enum. Ins. Austr. n. 807.

Ross. Fn. Etrusc. n. 906.

FIG. Schaeff. Icon. tal. 241. fig. 7, 8.

Tal. 18. fig. 1.

MUS. D. Marsham, M'Leay, Hawortin, Trimmer, Lathlury, Sowerby, Kirly.

Long. Corp. Lin. $6 \frac{1}{2}$.

IHab. Barhamix. In floribus haud rara.

DESCR. Mas.

CORPUS supra hirsutie flavâ, subtus atrâ, tectum.

CAPU x subglobosum, hirsuto-aterrimum. Vertex et Occiput flavo-villosa. Antenna vix thoracis longitudine, articulis subarcuatis.

TRUncus supra cingulo hirsuto-aureo, quod etiam pleuras pertingit, anticè insignis, dein fasciâ latâ atrâ, scutello flavescenti. Squamula piceo-nigræ. Ala coloratæ, apice nigricantes; nervis ferrugineis, costâ piceâ. Pedes atri, hirti. Spinule castaneæ. Scopula ferrugineæ. Digiti rufo-picei.

A BDOMEN triangulare segmento primo utrinque penicillo pilorum flavescentium instructo, secundo pilis atris, sed rariùs, hirsuto, reliquis hirsutie, densâ satis, lætè flavâ vestitis. Ani extremitas nigro-villosa.

Obs. In adultioribus hirsutiei jucunda favedo valde obscuratur, et ad cinereum vergit.

Faunæ Etruscæ docti auctoris hac Apis condecoratur nomine. 
A P I S. (**. e.'2.)

Age, as I have before observed, makes a great alteration in the colour of the hirsuties of the Bombinatrices. The bright and beautiful yellow, which adorns the insect before us when recently disclosed, fades, in such as are old, to a pale, dirty yellow. From a specimen in this state, Schrank probably drew his description, for I have no doubt of this being his $A$. sylvarum. A specimen of this insect in my cabinet, has one leg covered with cinereous hairs, while those of the other five are black.

86. A. atra, hirsuta; thorace anticè, scutello, ano-Leeana. que, flavis.

MUS. Kirly.

Long. Corp. Lin. $6 \frac{1}{2}$.

Hal. Barhamiæ, semel capta.

\section{DESCR. Mas.}

CORPUS atrum, hirsutum.

CAPu t subglobosum, totum atrum. Antenna vix thoracis longitudine, articulis subarcuatis.

Truncus supra anticè hirsuto-sulphureus, qui color in pleuras incurrit, dein ater, scutello obscurè flavo. Squamula piceæ. Ala subcoloratæ, apice obscuriores; nervis ferrugineis, costâ piceâ. Pedes atri, hirti, Spinulce castaneæ. Scopulce ferrugineæ. Digiti rufopicei.

Ав domen triangulare, hirsutum, segmentis duobus anticis atris, reliquis sulphureis. Ani extremitas atra. 
A P I S. (**. e. 2.)

Memoria D. Lee de Hammersmith, et Filiæ, qui insecta quamplurima rarissima, tam exotica quam indigena, colligebant, hac Apis inscrilitur.

A. Leeana is extremely similar to the preceding species but the hair of its vertex, and of the anterior half of its abdomen, is black. Both are of the same sex. Of the two, this is much the most rare.

- Francis. 87. A. atra, hirsisa ano flavescenti.

ana. MUS, D. Marsham arly.

Long. Corp. Lin. $5 \frac{1}{2}-6 \frac{r}{2}$.

Hal. Barhamiæ, bis capta.

DESCR. Mas.

CORPUS atrum, hirsutum.

Caput subglobosum, immaculatum. Antennee thoracis vix longitudine, articulis subarcuatis.

TRUNCUs supra hirsuto-nigricans. Squamula piceæ. Alce subcoloratæ, nervis, excepto costali piceo, ferrugineis. Pedes atri, hirti. Spi. nulce nigræ. Scopula ferrugineæ. Digiti picei

Ав оомеn subtriangulare, segmento penultimo et antepenultimo subinterruptè hirsuto-flavescentibus.

In honorem Rev. D. Francis Jungermanniarum Angliæ futuri elucidatoris, qui et in Entomologiâ multìm necfrustra sudavit.

The whole hirsutics of this bee is black, except a subinterrupted yellowish band at the tail. I suspect 
pect one of the three species that $I$ have described last, to be the male of that which I am next to notice, but as I know not which to fix upon, I must leave that point undecided till I can meet with the nidus. These three exactly resemble each other in form and habit, differing only in the colour of their hirsuties, whence a suspicion arises in my mind, that after all they, may turn out to be varieties only of the same species.

88. A. atra; hirsuta; thorace anticè, scutello, campes * anoque inflexo utrinque, flavis; abdomine subgloboso.

FIG. Apis campestris hirsuta nigra : thorace flavo fasciâ atrâ: abdomine nudo nitido, apice elongato acuminato, alis nigricantibus.

Panzer. Fn. Ins. Germ. Init. n.74, tal, 11.

Tal. 18. fig. 2.

MUS. D. Marsham, Trimmer, Lathlury. Kirly.

Long. Corp. Lin. 8.

Hab. Barhamiæ. In floribus tempore vernali et æstivo, e rarioribus una.

DESCR. Acul.

CORPUS atrum, hirsutum.

CA P T subtriangulare, immaculatum. Maxill $\boldsymbol{e}$ forcipatæ.

Truncus supra hirsuto-flavescens, fasciâ inter alas atrâ. Squamula nigræ. Alce fuscescentes, apice nervisque nigris. Pedes atri, hirti. Tibice posticæ supra pilosæ, nec corbiculâ nec pectine instructæ. Spinula nigræ. 
A PIS. (**. e. 2.)

Planta posteriores absque auriculâ. Scopula ferrugineæ, subauratæ. Digiti rufo-picei.

ABDOMEN, in mortuo saltem, subglobosum, nitidum; segmentis tribus anticis atro-subhirsutis. Anus incurvus, flavo subinterruptè hirsutus, segmento ultimo glabro, inflexo, subacuminato.

This insect, although it does not entirely agree with Panzer's description, is most accurately represented by his figure of his $A$. campestris, so as to leave no doubt of their identity: if my figure of it had not been taken when I received the number which contains his, I should have omitted it as unnecessary. The aculeate of this bee, as well as of two or three others of the present section, has no corbicula, nor is the apex of its posterior tibiæ furnished with a pecten, or its plantæ with an auricle at their base, like the other Bombinatrices.

lucorum. 89. A. supra hirsuto-flava; ano albido; thorace fasciâ nigrâ.

Apis lucorum hirsuta flava, ano albido.

Lin. Syst. Nat. Ed. 12. E Gmel. p. 2783, n.49. Fn.

Suec. $n .1716$.

Fal. Ent. Syst. Em. n. 35.

Vill. Ent. Eur. 3. n. 102.

Miill. Zool. Dan. n. 1926.

Schrank. Enum. Ins. Austr. $n 808$.

Apis Hypnorum. Ross. Fn. Etrusc, 2. n.905. Var. $\beta$.

FIG. Apis caspitum hirsuta atra: thorace citrino medio nigro: abdomine albo anticè citrino.

Panzer. Fn. Ins. Germ. Init. n. 81, tal. 19. Var. $\beta$. 
MUS, « D. Smith Linnean, Kirly. $\beta$ D. Marsham, Latham, Haworth, Trimmer, Lathbury, Kirly.

Long. Corp. Lin. 7.

Hab. Barhamiæ, $\alpha$ rarissima a me semel lecta; $\beta$ copiosissimè flores adit hortorum tempore autumnali.

DESCR. Mas.

CORPUS supra hirsutie flavâ, subtus flavescenti, tectum.

CAPUT subtriangulare, hirsutum. Maxilla barbâ rufescenti. Antennce capite longiores, articulis rectis.

Truncus supra Pleurceque hirsutie densâ fulvoflavâ tecta, fasciâ inter alas nigricanti. Squamula piceæ. Ala subhyalinæ, apice paulò obscuriores; nervis ferrugineis, costâ piceâ. $P e d e s$ hirti, pilis pro situ, nunc pallescentibus, nunc sordidè subnigris. Femora barbâ flavescenti. Tibia posticæ supra glabriusculæ, spinulis castaneis. Scopulce ferrugineæ. Digiti picei.

Aв DOMEn oblongum, hirsuto-flavum, segmentis duobus intermediis fasciâ angustâ obscưrâ nigrâ. Anus albido-hirsutus.

$V$ ar. $\beta$ corpore supra hirsuto-citrino; abdomine segmentis duobus anticis citrinis, proximis duobus nigris, ano albo.

Obs. In hâc varietate segmenta duo intermedia a latere conspecta interdum albescunt.

This is the true $A$. lucorum of Linneus, as appears upon a comparison of it with the authentic specimen 
specimen in the cabinet. $\mathrm{B}$, although at first sight it appears distinct, upon a close inspection will be found to be merely a variety of $\alpha$. The former of these has been mistaken by Rossi for A. Hypnorum, Linn. (which is a very different insect $(a)$, and approaches nearer to A. Muscorum and Beckwithella), it is extremely well figured by Panzer unthe name of $A$.caspitum. Of the latter, I have seen only the single specimen, except the Linnean, which $I$ have in my own cabinet. The black band of the thorax, in the authentic specimen, is nearly obsolete.

Jonella. 90. A. hirsuto-flava, ano albo; thorace abdomineque fasciâ atrâ.

MUS. Kirly.

Long. Corp. Lin. $6 \frac{1}{2}$.

Hal. Prope Londinum, a D. Trimmer semel lecta, et mihi transmissa.

DESCR. Mas.

CORPUS hirsuto-citrinum.

Caput. Maxillce barbâ rufâ. Vertex, item Gence posticè, atro-villosus. Antennce capite longiores, articulis supra rectiusculis, subtus convexis.

TRUNCUS supra hirsuto-citrinus, fasciâ inter alas atrâ. Squamulce picex. Alıe subcoloratx, nervis piceis. Pedes atri, hirti, femorum barba

(a) See Christii Hymenopt. tab.9. fig.7. which is one of the best figures of that author.

citrinâ. 
A PIS. (**. e. 2.)

citrinâ. Spinulce nigricantes. Scopulce ferrugineæ. Digiti picei.

ÁвдомеN triangulare; breve, segmento primo utrinque penicillo pilorum citrinorum ornato, proximis tribus hirsutis atris, ano albido. Fenter basi rariùs nigro hirsutus, apice sordidè albus.

In honorem D. Jones, Entomologi periti, et Lepidopterorum pictoris exquisiti, qui Papilionum ordines solerter et subtiliter illustravit (b).

91. A. atra, hirsuta, ano albo; thorace anticè,hortorums. scutello, abdominisque basi, flavis; capite elongato.

Apis hortorum hirsuta, nigra, thorace abdomineque anticè flavo, ano albo.

Lin. Syst: Nat. Ed. 12. E Gmel.p.2781.n.42. Fn: Suec. 1710.

Vill. Ent. Eur. 3, n. 96.

Schrank. Enum. Ins, Ausir. n.79\%.

Fn. Frid. n. 649.

Ross. Fn. Etrusc. n. $9 \mathrm{c3}$.

Forst. Cat. Brit. Ins. n.725. Apis, n. 19.

Apis ruderata hirsuta atra, thorace flavo fisciâ atrâ, abdomine anticè flavo, ano albo.

Fal. Ent. Syst. Em. n. 10.

Lin. Syst. Nat. ed. Gmel, p. 2781. n. 105.

Vill. Ent. Eur. 3. n. 10\%.

Apis paludosa hirsuta nigra, thorace anticè posticèque, abdomine anticè, flavis: ano albo.

Miill. Zool. Dan. n. 1919.

(b) Linn. Trans, vol, 2, p. 63-9.

TOL. II.

$\mathrm{Z}$ 
APIS. (**. e. 2.)

Apis nigra, thoracis basi et apice, abdominisque basi flavis, ano albo.

Geọlyr. Hist. Ins, 2. p.418, n.25.

Apis Iypnorum. Fourcroy. Ent. Par. n. 26.

Bomliylius major, niger, ano albo, cum triplici transversâ areo!â luteâ, linguam in 5 filamenta longa nigra divisam fulvam ex ore exerens.

Rai. Hist. Ins. p. 248. n. 11.

Mouffet. Theatr. p. 53. fig. dextr. infim.

FIG. Schaff: Icon. tal. 9. fig.7.

Apis ruderata. Christii Hymenopt. p. 128, tal.7. fig.4.

MUS. D. Smith Linnean, Marsham, $M^{c}$ Leay, Latham, $H a-$ worth, Trimmer, Lathlury, Kirly.

Long. Corp. Lin. 6-10.

$\mathrm{Hal}$. Barhamix. In floribus hortorum, vulgatissima ferè omnium.

DESCR. Acul.

CORPUS atrum, hirsutum.

$\mathrm{C}_{\mathrm{APUT}}$ anticè productum $(c)$. Os ferrugineobarbatum. Lingua involuta, corporis ferè longitudine.

Truncus. Thorax anticè cingulo denso, hirsuto-flavo, quod pleuras attingit. Scutellum hirsutie flavâ. Squamula rufo-piceæ. Alce subhyalinæ, apice obscuriores, nervis piceis costâ nigra. Pedes atri, hirti. Tilice posticæ nigro-piceæ. Spimula castanex. Scopulco ferruginex. Ligiti picei, articulo extimo rubello.

AвDомеN triangulare, segmento primo penicillis duobus villorum citrinorum tecto, prox-

(c) Tab. 13. fig. 9 . 
A PIS. (**. e. 2.)

imis duobus hirsutis, atris, Anus hirsutoalbus, apice subacuminatus.

Var. $\beta$ major; abdominis basi utrinque maculâ citrinâ; villi flavescentes etiam albedini ani incumbunt.

$\gamma$ dimidio minor; thoracis cingulo scutelloque citrino.

$\delta$ præcedente dimidio minor, aliàs simillima.

Maris Maxille pallidæe, barbầ nigrâ. Antennả

thoracis ferè longitudine, articulis subarcuatis. Thorax cingulo scutelloque citrinis. Tilice posticæ nigræ. Scopula fuscæ. Anus apicé extremo atro-villosus.

Var. $\beta$ thoracis cinguli, scutelli, abdominisque flavedine valde obsciurâ et ferè evanidâ.

Linneus, in his description of this insect, takes ho notice of the yellow hairs which cover its scutellum. This circumstance induced Fabricius to consider another as $A$. hortorum, and to give this as a new species under the name of $A$.ruderata. It is, however, the genuine $A$. hortorum, as appears upon a comparison of it with the authentic specimen of the Linnean cabinet. The Fabrician $A$ : hortorum stands by it, but without a label. The synonyms of Scopoli seem to belong to a variety of A. terrestris, for he describes it in these terms : "Thorace anticè flavo; abclonine fascià flavâ: apice albo $(d)$." To suit the insect before us, or

(d) Ent. Car. n. 817. Ann. Hist. Nat. 4. p. 10, n. 2. 
that which has been mistaken for it, it ought to be "abdomine lasi flavo." Miller, in his Zoologia Dinica, has described this Apis under the name of A. paludco: $\imath$ : of course his $A$. hortorum is another, most probably synonymous with that of Fabricius. The A. hortorum of Christius $(e)$, as far as I can judge from his figure, is no Bombinatrix.

The head of this species is much longer, in proportion to its width, than is usual in this family, in shape it bears no faint resemblance to the head of a dog, while others, with very little stretch of the imagination, may, in this respect, be regarded as similar to the cat.

Ray scems at a loss to conceive what can be the use of the complex machinery of the proboscis; we, who know the admirable art and contrivance manifested in the construction of this organ, need not wonder, but we shall be inexcusable if we do not adore.

rim- 92. A. atra, hirsuta, ano albo; thorace anticè, scutello, abdominisque basi, flavis.

MUS. D. Marsham, Haworlh, Trimmer, Kirly.

$$
\text { Long. Corp. Lin. 4-5. }
$$

Hal. Barhamia in floribus, sed rara.

\section{DESCR. Acul.}

CORPUS àtrum, hirsutum.

${ }_{20}$ C.APU T triangulare $(f)$. Os barbâ rufâ. Lingua

(e) Hymenopt. p. 140. tab. 11. fig. 3.

(f) Tab.13.fig. 10.

thoracis 
A PIS. (**. e. 2.)

thoracis longitudine. Occiput fillorum flavorum fasciculo ornatum.

Truncus. Thorax anticè cingulo hirsuto-citrino, quod pleuras pertingit. Scutellum citrinum. Squamulce rufo-piceæ. Alce subhyalinæ, nervis nigricantibus. Pedes atri, hirti. Spimulce castanex. Scopulce ferrugineæ. Digiti picei.

Ав домen triangulare, segmento primo villorum citrinorum penicillo utrinque instructo, proximis duobus atro-hirsutis, ano albo.

Maris Maxillce pallidæ, barbâ nigrâ. Antennce thoracis longitudine, articulis subarcuatis. Scopula fuscæ. Anus segmentis duobus ultimis atro-villosis.

In honorem D. Schrimshire fratrum. "Arcades ambo."

This little bee is very liable to be confounded with the preceding, but it may always be known by the shape of its head, which, like that of most other Bombinatrices, represents an equilateral triangle, with rounded angles. The last segment of the abdomen, of the aculeate, is likewise shorter.

93. A. atra, hirsuta, ano albo ; vertice, thorace an- Barluiticè, scutelloque, fulvis; abclomine subgloboso. ${ }^{\text {ella. }}$

Bombylius major niger, duplici in supinâ parte ạreâ, anteriore latiore e fulvo albicante, posteriore angustâ albicante.

Rai. Hist. Ins. p. 2 48. n. 17. Acu!. Var. ? 


\section{MAS. Var. $\beta$.}

Apis autumnalis hirta, thorace cinerascente fasciâ nigra; abdomine atro basi cinerascente, ano albo.

Fal. Ent. Syst. Em. n. 43.

FIG. Apis saltuum hịrsuta atra, thorace albo fasciâ nigrâ; abdomine anticè anoque albis.

Panzer. Fn. Ins. Germ. Init. n.75. tal. 21.

Apis monacha. Christii Hymenopt.p. 131, tal. 8. fig.7.

MUS. D. Marsham, McLeuy, Haworth, Trimnter, Lathlury, K̈̈rly.

I.ong. Corp. Lin. 6-9.

Ha!. Barhamia. In floribus tempore astivo haud rara. Mas in Caxcluis frequens.

DESCR. Acul.

CORPUS atrum, hirsutum.

CAPUT subglobosum. Os barbâ nigricanti. Lingua thoracis longitudine. Maxilla forcipatæ. Vertex et Occiput fulvo-villosa.

Truncus. Thorax anticè hirsuto-fulvus. Scutellum hirsutie sardidè fulvescenti. Squamula nigræ. Alce fuscescentes, apice nigræ; nervis nigricantibus. Pedes atri, hirti. Tibice posticæ supra pilos $x$, neque corbiculâ neque pectine instructæ. Plantce posteriores absque auriculâ. Spinulce castạneæ. Scopula fuscæ. Digili picei.

АвDомEN subglobosum, incurvum, rariùs hirsutum, segmento primo villis certo situ flavescentibus utrinque instructo. Anus hirsuto-albiclus, segmento ultimo glabro, inflexo, subacuminato, 
A PIS. (**. e. 2.)

Maris Maxille pallidæ, barbâ nigrâ. Antenna capite longiores, articulis rectiusculis. Vertex villis citrinis. Thorax anticè fasciâ citrinâ. Squamula piceæ. Alce dilutiores, venis tenuioribus testaceis. Spinulce nigræ. Scopula ferrugineæ, vix auratæ. Aldomen triangulare, subacuminatum, segmento primo villorum flavidorum, penicillo utrinque ornato. Anus albus, extremitate nigro-villosus, haud inflexus.

Var. $\beta$ adultior; thoracis fasciâ, scutello, abdominisque basi hirsuto-cinerascentibus. $\gamma$ thoracis basi et apice obscurè flavescentibus; abdominis basi immaculatâ. Obs. In quibusdam scutellum nigricat.

In honorem D. Barbut, qui Insectorum et Vermium Genera figuris illustravit.

This insect exlibits the same peculiar characters as $A$. campestris. A. autumnalis of Fabricius, A. saltuum of Panzer, and A. monacha of Christius appear to me to be all intended for variety $\beta$ of the male. This variety is common late in the year upon thistles, and is nothing more than a grown grey from age : its wings, when it is in this state, will always be found to be torn at their tips. The synonym of Ray, n. 15. I refer to the aculeate of this Apis, because he says, "Superior area lata est, et mediâ parte in angulum excurrit ad frontem," which is exactly the case with ours. His description was probably taken from a specimen in which the hair was faded. 
- Tunstall-94. A. atra, hirsuta, ano albo; thorace anticè scus ana. telloque fulvescentibus.

$$
\text { ACUL. Var. } \varepsilon \text {. }
$$

Apis veterana hirsuta cinerea, thorace fasciâ nigrâ.

Fal. Ent. Syst. Em, n. 45 ?

MUS. D. Mursham, Latham, $M^{\mathrm{c} L e a y, ~ H a w o r t h, ~ L a t h b u r y, ~}$

Trimmer, Kirly.

Long. Corp. Lin. $5 \frac{1}{2}-10$.

Hal. Barluamiæe, cụm præcedentibus frequens.

DESCR. Acul.

CORPUS atrum, densè hirsutum.

CAPUT anticè productum. Os ferrugineo barbatum. Lingua vix corpore brevior.

Truncus. Thorax anticè fasciâ hirsutâ, haud latâ, fulvâ. Scutellum hirsuto-fulvum. Squamula piceæ. Ala infuscatæ, apice obscuriores. Pedes atri, hirti. Spinulce nigrx. Scopula ferruginex, Digiti picei, articulo ex timo rubello.

AвDOMEN ex oblongo triangulare, mollisimè hirsutum et quasi velutinum, ano albido.

$V a r . \beta$ ano hirsutie grisescenti.

$\gamma$ dimidio minor; alis subhyalinis apice nigris; digitis ferrugineis; aliàs $\alpha$ similis. $\delta$ pracedenti dimidio minor; thoracis cingulo scutelloque citrinis; alis subhyalinis; digit is ferrugineis.

$\varepsilon$ adultior, pracedentis fere magnitudine; thorace antice, scutello, abdomineque, hirsuto-cinerascentibus. 
A PIS. $(* *$, e. 2.)

Obs. Abdominis hirsuties in hấc varietate a latere conspecta est cinerea, a dorso e cinereo nigricat.

Memorice D. Tunstall rerum naturalium collectoris assidui, hee Apis inscribitur.

A. Tunstallana possesses many characters in common with $A$. hortorum. The female, however, is larger, the hair of its scutellum, and of the anterior part of its thorax, is tawny, and not yellow, and that which covers the first abdominal segment is black; its wings are darker, and its abdomen inclines more to an oblong form. Variety $\varepsilon$, and which is in fact merely $\delta$ long disclosed, agrees with the description of $A$. veterana of Fabricius.

95. A. atra, hirsuta, ano albo, apice nigro; thorace vestalis. basi flavo.

Apis nigra, thoracis basi flavâ, ano supra flavo apice albo.

1. Geoffr. Hist. Ins. Par. 2. p. 419. n. 26.

Apis vestalis. Fourcroy. Ent. Par. n. 26.

FIG. Tal. 18. fig. 3. Acul. Ilid. fig. 4. Mas.

MUS. D. Marsham, Latham, Drury, Haworth, Lathlury, Trimmer, Kirly.

Long. Corp. Lin. 7-9.

Hal. Barhamiæ, florente Farfarâ obvia, sed haud frequens. Prope terram sæpius volat.

DESCR. Acul.

CORPUS atrum, hirsutum.

CAPU t subglobosum. Maxille forcipatæ.

Truncus supra cingulo antico, hirsuto, fulvoflavo ornatus. Squamulce atræ. Alae paulò infuscatæ, 
infuscatæ, apice nervisque nigricantibus, venis tenuioribus testaceis. Pedes atri, hirti. Tibia postic $x$ neque corbicula, neque pectine instructæ. Spinulce castanex. Planta absque auriculâ. Scopulce vix auratæ, ferrugineæ. Digiti tomentoso-rufi.

АвромеN ex globoso oblongum, incurvum, hirsutum, segmento tertio margine utrinque flavo, quarto toto quintique lateribus albidis, ultimo glabro, nitido, inflexo, subacuminato. $V$ ar. $\beta$ dimidio minor.

Maris Antennce thorace breviores. Aldomen fasciâ posticâ hirsuto-albâ. Anus ipse nigrohirsutus.

This is again another of those Bomlinatrices, which, like $A$. campestris and Barlutella, have no instruments for carrying or preparing masses of pollen. The posterior tibix, of one specimen in my cabinet, is covered from one end to the other with a thin coat of pale earth, mixed with particles of sand; they probably use this in constructing their nests or cells. This species was known to Geoffroy, who has described it with great accuracy in the following terms: "Cette grande espéce est noire. Le haut ou la base de son corcelet a une bande de poils jaunes citrons. Les deux tiers supérieurs du ventre sont noirs, ensuite il y a quelques poils jaunes, et son extrémité est blanche. Les alles sont brunes." He has neglected, however, to notice the black extremity of the anus. 
A PIS. (**. e. 2.)

96. A. atra, hirsuta, ano albo; thoracis cingulo, virginalis . abdominisque segmentis duobus anticis, flavis. Apis nigra, thoracis abdominisque basi flavis; ano albo.

Geoffr. Hist. Ins. Par. p. 418, n. 24.

Apis virginalis. Fourcroy. Ent. Par, n.25.

Apis hortorum. Fal. Ent. Syst. Em. n. 22.

Miill. Zool. Dan. n. 1918.

MUS. D. Smith Linnean, Marsham, McLeay, Haworth Trimmer, Kirly.

Long. Corp. Lin. $4 \frac{1}{2}-7$.

$\mathrm{Hal}$. Barhamiæ, in floribus cum sequente obvia.

DESCR. Acul.

CORPUS atrum, hirsutum.

CAfut subglobosum. Os barbâ rufescenti, Proboscis vix thoracis longitudine, palpis exterioribus acutis.

Truncus. Thorax anticè densè hirsutus, fulvoflavus. Squamula piceæ. Alæ subhyalinæ, apice paulò obscuriores, nervis nigris, tenuioribus testaceis. Pedes atri, hirti. Spinulce ferrugineæ. Scopula fuscæ, sub luce argentatæ. Digiti obscurè ferruginei, articulo extimo dilutiori.

ABDomen subglobosum, hirsutum, segmento primo villorum flavescentium penicillo utrinque ornato, secundo citrino, tertio atro, ano albido.

Yar. $\beta$ minor; abdomine segmenti primi penicillis nigris, segmento quarto etiam atro.

Maris 
APIS. (**. e. 2.)

Maris Maxille pallidx. Antenna capite lon. giores, articulis rectiusculis. Truncus supra cingulo antico hirsuto, citrino. Pleura citrino-villosæ. Tilice posticæ supra vix pilosæ. Scopula ferruginex. Aldomen segr... ${ }^{n+1}$ duobus anticis hirsutis citrinis, proximis duobus atris, ano albo.

Obs. Feminam nondum vidi, mas neutro duplo major.

This, I take to be the insect which Fabricius looked upon as $A$. hortorum of Linneus. The tuft of yellow hairs, which is observable on each side of the first dorsal segment of the abdomen, is sometimes black, which brings this species very near to A. terrestris. In that, however, the whole of this segment is hairy, and not the sides only; its abdomen is also proportionably longer, and the scopulæ are of a different colour; not to mention, that in one, the exterior palpi are acute, and in the other, truncate. I have not yet met with the female of this species, but Geoffioy knew it.

terrestris.97. A. atra, hirsuta, ano albo; thoracis basi, abdominisque fasciâ, flavis.

Apis terrestris hirsuta nigra, thorace cingulo flart, ano albo.

Lin. Syst. Nat. Ed. 12, छ Gmel. p. 2ౌ\$1, n.41. Fn. Suec, 1709.

Fab. Ent. Syst. n. 8.

Vill. Ent. Eür. 3. n. 95.

Scop. Ent. Car, n. 815. Ann. Hist, Nat. 4, p. 10. $n, 3$.

$F n$, 
Fn. Frid. $n .648$.

Miill. Zool. Dan. n. 1917.

Ross. Fn. Etrusc. 2, n. 902.

Forst. Cat. Brit. Ins, n. 724. Apis, n. 18.

Berkenhout. Synops. 1. p. 159. n.6.

Apis hortorum. Scop. Ent. Car. n. 817. Ann. Hist. Nat. 4. p. 10. n.2?

Bombylius magnus niger, duplici in dorso areâ trans. versâ fulvâ, caudâ albâ.

Rai. Hist. Ins. p. 248, n. 15. Acul: $\alpha$.

Bombylius major niger, duplici transverso ductu luteo, alio supra scapulas torquis loco, alio per medium abdomen; imo abdomine $\int$. ano albo.

Rai. Hist. Ins, p. 247. n. 5. Mas $\alpha$.

IIG. Mouffet. Theatr.p. 53.

Goedart. Ins. 2. tab. 46. List. Goedart. fig. 105.

Bradtèy Nat. tab. 26. fig. 1. D.

Reaum. tom. 6. Mem.1. p. 2. tal.3. fig.1.

Frisch. Ins, 9, tal. 12. fig. 1.

Sulz. Ins. tab. 19. fig. 124.

Schaeff. Icon. tab.251.fig.7. Fund. Ent. tal.20. fig.6.

Christii Hymenopt. p. 117. tal. 7. fig. 2.

Barbut. Gen. Insect. tab. 15. Apes, fig. 2.

Panzer. Fn. Ins. Germ. Init. n. 1. tal. 16.

MUS. D. Smith Linnean, Marsham, McLeay, Hawortì, Sowerby, Lathbury, Trimmer, Kirby.

\section{ACUL. Var. $\gamma . \varepsilon$.}

Apis Graminum hirsuta atra, thoracis basi, abdominisque fasciâ anoque, fulvis.

D. Marsham. MS.

Bombylius maximus, niger, caudâ fulvâ, areolâ etiam fulvâ transversâ abdomen supinum dividente.

Rai: Hist. Ins. p. 247: n. 6. Var. $\varepsilon$.

FIG. Seba Thesaur. 4. tab.96. fig.7.

Harris. Exp: Eñg. Ins tal. 38. fig. 1-4. 
APIS. (**. e. 2.)

Apis terrestris. Barbut. Gen. Ins, tal. 15. Apes, fig. 1 Donovan. Eng. Ins. tab. 88. fig. 1.

MUS. D. Marsham, Haworth, Trimmer, Lathlury, Kirly. Long. Corp. Lin. 6-10.

Hab. Barhamiæ. Sub terrâ profundê nidum ponit.

Circa cacumina Pseudoplatani tempore inflorescentiæ vespere volitant frequentes, sonorè bombilantes Florente Salice feminá prodit.

DESCR. Acul.

CORPUS atrum, hirsutum.

$\mathrm{CAPUT}_{\mathrm{A}}$ ex triangulari subglobosum. Os barbâ rufescenti. Proloscis vix capite longior, palpis exterioribus attenuatis apice oblique truncatis $(g)$.

Truncus. Thorax anticè hirsutie densâ fulvoflavâ. Squamule nigræ. Alce coloratæ, apice obscuriores, nervis nigricantibus, tenuioribus ferrugineis. Pedes atri, hirti. Spinula et Scopula ferruginex. Digiti tomentoso-rufescentes.

ABDOMEN oblongum, densè hirsutum, basi atrum, dein fascia fulvo-flavâ, medio iterun atro, ano albo.

Var. $\beta$ minor; thoracis basi flavâ; alis subhyalinis apice nigricantibus.

$\gamma$ major; thoracis basi, abdominis fascia mediâ, anoque, fulvis.

$\delta$ ano pallido, aliàs $\gamma$ similis, $\varepsilon$ thorace atro, immaculato, aliàs $\gamma$ simillima.

(g) Tab. 13. fig. 3. ᄂ. \& fig. 4.

Obs: 
Obs. Fascice thoracice rudimenta, tamen valdè olscurata et ferè evanida, retinet hrec varietas. Maris Maxilla pallidæ, barbâ rufescenti. Tho$\operatorname{rax}$ hirsutie anticâ pallidè flavâ $\int$. luteâ. Tibia posticæ supra glabriusculæ, pilis lateralibus cinerascentibus. Scopula fuscæ. Abdomen subglobosum, fasciâ mediâ pallidè flavâ $\int$. luteâ.

$\operatorname{Var}, \beta$ thoracis basi, abdominisque fasciâ, fulvis; ano pallido.

Obs. Hujus Apis palpi exteriores longiores quàm vulgò obtinet in hâc familiâ.

I had followed my friend Mr. Marsham in considering variety $\gamma$ as a distinct species, on account of its tawny anus, at the same time still suspecting from its great similarity in other respects to $A$.terrestris, that it might be merely a variety of that insect. Reaumur's observation upon this species, gave strength to this suspicion-" Ceux (les poils) de la troisiéme (bande) ou du bout du corps, sont blancs ou jaunâtres $(h)$," says he; and receiving information from Mr. James Trimmer, that he had found this in the same nest with $\alpha$, I was convinced at last that my suspicion was well founded, and that it ought only to be considered as a sexual variety. I take it to be the female, from the circumstance of its making its appearance early in the spring. The synonym of Ray belongs to one that retains the faintest trace possible of the yellow band

(h) Reaum. tom. 6. Mem. 1. p. 34. 
of the thorax, and which, incleed, is scarcely visible to the naked eye. I have a specimen of this in my cabinet: it furnishes an instance of the tendency of these insects to vary, even such as have been recently disclosed, (for of this description is my specimen), in the colour of their hirsuties. If the band vanishes from the thorax, it may vanish, likewise, for aught we know, from the abdomen; in that case, a would become $A$. soroensis, Fab. I mention this, to shew how very liable we are to err in our determination of species in this family. Ray has given the male and common aculeate as distinct species, misled by the different hue of the anterior part of the thorax, and of the abdominal band, which in the one is pale, and in the other tawny-yellow. These, however, in variety $\beta$ of the male, are also of the latter colour, but $\alpha$ is the most common. I have often been amused, at the time of the sycamore's being in flower, with seeing these insects, by myriads, busily engaged upon its very summit, in collecting honey and pollen from its blossoms, and making a hum that might be heard at a considerable distance, and this even after sun set. They are as alert in the morning; I have frequently seen them at work in my garden, when the gooseberry was in blossom, before seven o'clock:

Soroensis.98. A. atra, hirsuta, ano albo.

Apis Soroensis hirsuta atra, ano albo.

Fal. Ent. Syst. Em, n. 12.

$\operatorname{Lin}$. 
A P I S. (**. e. 2:)

Lin. Syst. Nat. Ed. Gmel. p. 2781, n. $10 \%$.

Vill. Ent. Eur. 3, n. 109.

Apis Cardui hirsuta nigra, ano albo.

Miill. Zool. Dan. n. 1929.

FIG. Scheef. Icon. tal. 251, fig. 6.

Panzer. Fn. Ins. Germ. Init. n.7. tal. 11.

MUS. D. Haworth, Kirly.

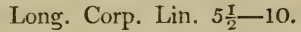

Hab. Prope Londinum, a D. Haworth et Trimmer lecta.

DESCR. Acul.

CORPUS atrum, hirsutum.

$\mathrm{C}_{\mathrm{APUT}}$ anticè productum. Os barbâ rufâ. Proboscis vix corporis longitudine.

Truncus anticè utrinque puncto obsoleto flavo.

Squamul.e piceæ. Alce paulò infuscatæ, apice nervisque nigricantibus. Pedes atri, hirti. Spinulce nigræ. Scopula ferrugineæ. Digiti picei.

Ав Domen ex triangulari oblongum, hirsutum, aterrimum, ano albido.

V́ar. $\beta$ triplo minor, tibiis posticis corbiculâ pallidâ, scopulis fuscis; digitis ferrugineis.

This insect may possibly be only a variety of A. Tunstallana, which it greatly resembles; but a is a specimen recently disclosed, therefore the hirsuties cannot have changed its colour from age; and as that is almost the only mark in this family, short of the inspection of the nest, by which we have to steer our course, I lave, with Fabricius, given it as distinct.

VOL. II. 
sulinter- 99. A. atra, hirsuta, ano fulvo ; thoracis basi abrupta. dominisque fascià anticâ ; flavis.

Apis sulinterrupta. MS. D. Marsham.

Apis nigra, thoracis abdominisque basi flavis, ano fulvo. Geoffr. Hist. Ins. 2. p.417. n. 23. Var. $\gamma$.

Apis regalis. Fourcroy. Ent. Par. n. 24.

Bombylius medius niger ano fulvo $\digamma$. rufo, cum duplici transversâ areâ luteâ, alterâ supra scapulas, alterâ per medium abdomen.

Rai. Hist. Ins. p. 247. n. 10.

FIG. Scha.ff. Icon, tab. 250. fig. 4 .

Apis listriata. Christii Hymenopt. p. 128. tab.7. fig.3. Tal, 18. fig. 5. Acul.

MUS. D. Marsham, Hau'orth, Lathlury, Trimmer, Kirly.

Long. Corp. Lin. 6-8 $\frac{1}{2}$.

Hab. Barhamix. In Salicum amentis ineunte Aprili 1800 , haud rara,

DESCR. Acul.

CORPUS atrum, hirsutum.

CAfut. Os rufo-barbatum. Lingua vix cors pore brevior. Palpi exteriores tenues.

Truncus. Thorax anticè densè hirsutus, fulvoflarus. Squamule piceo-nigræ. Ala subcoloratæ, apice obscuriores, nervis nigricantibus. Pedes atri, hirti. Spinulce nigræ. Scopulce ferruginer. Digiti picei.

AвDOMEn oblongum, hirsutum, segmento primo atro, secundo subinterruptè flaro, proximis duobus quintique basi atris, ano fulvo.

Var. $\beta$ abclominis fasciâ flavà ferè absolutâ. $\gamma$ duplo minor; thoracis basi, abdominisque segmentis 
A 513 . (**. e. 2.)

segmentis duobus anticis subinterruptè, citrinis; squamulis rufo-piceis.

Obs. In hấc varietate basis intima abdominis pili atri. An eadem?

Maris Caput subglobósum. Maxille barbầ nigricanti. Antennce capite longiores, articulis rectiusculis. Squämulce nigræe. Alce venis tenuioribus ferrugineis. Tilice intermediæ hinc barbâ albidâ. Spinula castaneæ. Digitî obscurè ferruginei.

100. A: atrá; hirsuta, ano rufo; thoracis abdomi-Donovan: nisque basi flavâ.

FIG. Tal. 18: fig. 6. Mas.

MUS. Kirly.

Long. Corp. Lin. $5 \frac{3}{4}-7 \frac{1}{2}$.

$\mathrm{Hal}$. Bärhamiæ: In floribus rara.

DESCR. Ȧcul.

CORPUS atrum, hirsutum.

CAPU T. Os barbâ rufescenti.

TRUncus. Thorax anticè hirsutie densấ citrinắ.

Squamule nigræ. Alle fuscessentes, apice nervisque nigricantibus. Pedes atri, hirti. Spinulce nigræx. Scopulce ferrugineæ. Digiti picei.

Ádomen ex triangulari subglobosum, hirsutum, basi latè citrinum, dein fasciâ atrâ, segmentis tribus ultimis rufis.

Maris Antennce thoracis longitudine. Thorax fasciâ citrinâ anticà obscuriori. Digiti ferruginei.

2 A 2

In 
In honorem D. Donovan, qui Insectorum, Avium, Conchyliorum M. Britannix Historiam Naturalem figuris et obseriationibus illustravit, necnon Insecta Chinensia et Indiæ Orientalis exquisitissimè figuravit.

This insect approaches very near to $A$. sulinterrupta, but the wings are darker, the abdomen is shorter and wider, its black band is much narrower, the red hairs of the anus are of a deeper colour, and occupy three segments.

- Eurrell- 101. A. hirsuto-flava, ano fulvo; thoracis abdomiana. nisque subglobosi fasciâ atrâ.

Apis flava, abdominis medio nigro, ano fulvo.

Geo Dr. Hist. Ins. 2. p. 418, n, 23. NB.

Apis regalis, B. Fourcroy. Ent. Par, n. 24.

FIG. Scluafl: Icon, tal. 261. fig. 5, G.

MUS. D. Harsham, Latham, M*Leay, Hau'orth, Lathlury,

Trimmer, Kirly. Long. Corp. Lin. 6.

Hal. Barlamiæ. In fluribus hortorum haud rara.

DESCR. Mas.

CORPUS hirsuto-citrinum.

Caput. Maxillıe barbâ fulvescenti. Antenna thoracis longitudine, articulis rectiusculis.

Tru ncus supra anticè latè hirsuto-flavus. Thorax inter alas ater. Squamulce nigre. Alce subcolorat $x$, apice obscuriores, nervis piceis. Pedes flavescente-hirti. Femora quatuor posteriora pallido barbata, anteriora citrina. Spi- 
APIS. (**. e, 2:)

nula nigræ. Scopule fuscæ, vix auratæ. Digiti picei.

AвDOMEN subglobosum, hirsutum, segmentis duobus anticis citrinis, intermediis totidem atris, ano fulvo. Venter hirsutie pallidâ.

Obs. In adultioribus corporis hirsuties plìs minùs cinerascit.

Inhonorem Rev. D. Burrell, insectorum collectoris assidui.

Geoffroy gives this as a variety of $A$. subinterrupta, but we know the male of that insect, which is very different, and quite distinct from this.

102. A. hirsuto-pallida ; ano ferrugineo ; thoracis Cullum. abdominisque fasciâ atrâ.

MUS. Kirly.

$$
\text { Long. Corp. Lin. } 6 \frac{1}{2}
$$

$\mathrm{Hal}$. Witneshamiæ prope Gippovicum in Suffolciâ, semel capta.

\section{DESCR. Mas.}

CORPUS hirsuto-pallidum, $\int$. pallidè flavum.

CAPU T. Maxilla barbâ pallidâ. Vertex, Occiput utrinque, Gena posticè, atro pilosa. Facies ante antennas fasciculo denso villoso-pallido insignita. Antennce trunci ferè longitudine, articulis subarcuatis.

Truncus. Thorax faciâ inter alas atrâ. Squamula piceæ. Ala subhyalinæ, nervis nigricantibus. Pedes pilis atris cinereisque mixtis hirti. Spinula castaneæ. Scopula fuscæ, vix auratæ. Digiti nigro-picei.

Yol. II.

A 3

ABDomen 
AвDOMEN ex ovato oblongum, hirsutum, segmentis duobus anticis flavescentibus, intermedio atro, ano ferrugineo.

In honorem D. T. G. Cullum, Baronetti, viri amicissimi, et Naturaindagatoris docti, indefessi.

It is probable that in a recent specimen (that from which this description was drawn, having apparently been some time disclosed) the hirsuties of the body of this species would be of a lemon colour. It differs from the preceding in the form of its abdomen, and of the joints of its antennæ, and only one abdominal segment is black.

pratonum.103. A. atra, hirsuta, ano fulvo; thorace anticè flavo.

Apis pratorum hirsuta nigra, thorace anticè flavo, ano rubro.

Lin. Syst. Nat. Ed. 12. छ Gmel. p. 2781. n. 43. Fn. Suec. $n .1711$.

Vill. Ent. Eur. 3. n. 97.

Schrank. Enum. Ins. Austr. n, 798.

Fn. Frid. x. 650.

Miill. Zool. Dan. x. 1920.

Forst. Cat. Brit. Ins. n.720. Apis, n. 20.

Bombylius minor niger, transversâ areola e viridi luted̂ supra scapulas, extremâ caudâ rufescente.

Rai. Hist. Ins. p. 247. n. 8.

FIG. Harris. Exp. Eng. Ins. tal. 40. fig. 9.

MUS. D. Smith Linnean, Marsham, Latham, McLeay, Haworth, Lathbury, Trimmer, Kirly.

Long. Corp. Lin. $4-7$.

Hab. Barhamix. In hortis flores Rilis, et Ruli idai vulgatissima adit.

DESCR. 
DESCR. Acul.

CORPUS atrum, hirsutum.

Captr. Proloscis vix thorace longior. Os barbâ rufescenti.

Truncus. Thorax basi hirsutie densâ flavâ. Squamula piceæ. Alce fuscescentes, apice paulò obscuriores, nervis nigris. Pedes atri, hirti. Spinule nigræ. Scopula ferrugineæ. Digiti obscurè ferruginei.

Ав Dомеn oblongum, hirsutum, atrum, ani extremitate fulvâ.

$V$ ar. $\beta$ dimidio minor; scopulis fuscis.

$\gamma$ præcedenti duplo minor; alis subcoloratis nervis ferrugineis; abdomine subgloboso.

Obs. In plerisque rudimenta, obscurissima tamen, fascice antica flavescentis aldomen exhilet.

This is the genuine $A$. pratorum of the Linnean cabinet; $A$. arbustorum of Fabricius, which he gives as $A$. pratorum, is a different insect, as we shall see hereafter. I have a strong suspicion that the one before us is nothing more than a variety of $A$. subinterrupta, before described, for a very faint trace of a yellow fascia is observable upon the abdomen of $\alpha$ and $\beta$, but not upon $\gamma$; this last is the smallest Bombinatrix with which I am acquainted.

104. A. atra, hirsuta, ano rufo; thoracis limbo, Allinella. abdominisque lateribus, cinerascentibus.

FIG. Apis frutetorum hirsuta nigra, thorace cinerascente fasciầ nigrâ, abdomine basi cinerascente, ano fulvo. 
14PIS. (**. e. 2.)

Panzer. Fn. Ins. Germ. Init. n. 75. tab. 20.

AIUS. D. Marsham, Trimmer, Lathlury, Kirly.

Long. Corp. Lin. 7.

Hal. Barhamix. In floribus tempore autumnali, rarior tamen.

DESCR. Mas.

CORPUS atrum, hirsutum.

CaPUt subglobosum. Maxilla barbậ nigricanti. Antennce thorace breviores, articulis rectiusculis.

Truncus supra limbo cinerascenti. Squamula piceæ. Alce fuscescentes, nervis nigricantibus. Pedes fulvescente-hirti, femorum barbâ nigrâ. Spinulce nigræ. Scopulce obscurè ferruginex. Digiti nigri.

АвDомen ex globoso oratum, hirsutum, segmento primo secundique margine utrinque cinerascentibus. Anus acutiusculus, rufofulvus.

Var. $\beta$ thorace atro basi obscurè flarescente; peclibụs hirșutie sordidè nigricanti.

$\Upsilon$ had printed my Synopsis Specierum before I saw Panzer's figure of this insect, or I should have given it under the same name, I suspect it may be the male of one I shall shortly describe. Its abdomen is narrower at the base than is usual in this fanily. Variety $\beta$ may possibly be the male of a different species. Its trunk, instead of being surrouncled with cinereous hairs, has only an obscure yellowish band next the head, and the base of the abdomen, 
abdomen, except it be viewed a latere, appears black, with a cinereous spot on each side. In form, however, and habit it agrees with $\alpha$.

105. A. hirsuta, fusco-cinerascens, ano fulvo ; tho-Derhameracis abdominisque fasciâ atrâ.

FIG. Harris, Exp. Eng. Ins, tab. 38, n. 4?

MUS. D. Marsham, Haworth, Trimmer, Kirby.

Long. Corp. Lin. 6.

Hal. Barhamiæ, haud rara.

DESCR. Mas.

CORPUS hirsutum, hirsutie fusco-cinereâ.

CAPUT triangulare, atro-hirsutum. Antenna thoracis longitudine, articulis subarcuatis. Facies circa antennas pilis cinereis nigrisque mixtis.

Truncus. Thorax inter alas ater, item Pleurce posticè. Squamulce piceæ. Alce subhyalinæ, nervis piceis. Pedes pilis fusco-cinereis, ast certo situ nigris, hirti, tibiis plantisque quatuor posticis hinc rufescente-ciliatis. Spinulce nigræ. Scopule Digitique fusco-ferruginea.

AвDOMEn ex globoso ovatum, hirsutum, segmentis duobus anticis fusco-cinereis, tertio atro, reliquis fulvis.

106. A. corpore femineo atro, hirsuto, ano rubro : lapidaria. . corpore masculo supra atro, hirsuto, ano rubro; facie, thoracisque basi et apice, flavis. 


\section{ACUL.}

Apis lapidaria hirsuta, atra, ano fulvo.

Lin. Syst. Nat. Ed. 12. E Gmel. p. 2782. n.44. Fn.

Suec, n. 1712.

Vill. Ent. Eur. 3. n. 98.

Scop. Ent. Car. n. 813. Ann. Hist. Nat. 4. p. 10. n. 1.

Schrank. Enum. Ins. Austr. n.799.

Frisch. Ins. 9. p. 25. n. 2.

Pod. Ins. Grec. p. 110.

Fn. Frid. $n .651$.

Miill. Zool. Dan. n. 1921,

Geoffr. Hist. Ins. 2. p. 417, n.21.

Fourcroy. Ent. Par. n. 22,

Forst. Cat. Brit. Ins, n. 727. Apis, n. 21.

Apis lapidaria hirsuta, atra, ano fulvo, alis albo-hyalinis. Fal. Ent. Syst. Em. n. 25.

Bomlylius maximus totus niger, exceptis duobus ex tremis abdominis annulis rubris.

Rui. Hist. Ins. p. 246. n. 1.

FIG. Mouffet. Theatr. p. 53. fig. sinstr. infim.

Reaum. tom. 6. Mem. 6. p. 2, 3. tab. 1. fig. 1-4.

Scha.f. Icon. tal. 69. fig. 9.

Christii Hymenopt. p. 126. tal. 7. fig. 1.

Barlut. Gen. Insect. tal. 15. Apes, fig. 3.

Harris. Exp. Eng.Ins. tab.38. fig. 1. tal.40. fig.12, 15. Donovan. Eng. Ins. tab. 108. fig. 1. tab. 58. fig. 2. Var. $\beta$. Shaw. Natural. Miscell. n. 135.tab. 454.

Apis pratorum. Christii Hymenopt. p. 141. tal. 11 , fig. 5. Var. $\beta$.

MUS. D. Smith Linnean, Marsham, Latham, MeLeay, Haworth, Lathbury, Trimmer, Kirby.

\section{Mas.}

Apis arlustorum hirsuta nigra, thorace anticè flavo, ano rubro.

Fal. Ent. Syst. Em. n. 24. 
APIS. (**. e. 2.)

Apis nigra, fronte basique thoracis flavis, ano fulvo.

Geoffr. Hist. Ins. 2. p. 417. n. 22.

Apis coronata. Fourcroy. Ent. Par. n. 23.

Bomlylius medius niger, caudâ rubrâ, supra scapulas torque e viridi luteâ caput ferè cingente, cum insignị velut penicillo pilorum luteorum splendentium in mediâ facie inter oculos,

Rai. Hist. Ins. p. 247. n. 7.

fIG. Harris. Exp. Eng. Ins, tab. 38. fig. 5.

Apis hamorrhoidalis, Christii Hymenopt. p 132. tab.

9. fig. 2.

MUS. D. Marsham, Latham, $M^{\complement}$ Leay, Haworth, Lathlury,

Trimmer, Kirly.

Long. Corp. Lin. 5-10.

Hal. Barhamiæ. In floribus frequens, præsertim col-

lium, tempore æstivo. Prædatur mel apum, plerum: que infeliciter. Scop. Habitat in Lapidum acervis strenuè mellificans. Liın. Nobiscum sub terrâ nidificat.

DESCR. Acul.

CORPUS atrum, hirsutum.

Caput. Os rufo-barbatum. Proboscis vix thoracis longitudine, palpis exterioribus tenuioribus, elongatis.

Truncus immaculatus, hirsutie densâ, aterrimâ vestitus. Squamule nigræ. Ale corpore breviores, subhyalinæ, apice paulò obscuriores, nervis nigricantibus. Pedes atri, hirti. Spinulce atque Scopulce ferrugineæ. Digiti tomentoso-rufi.

A В DомеN oblongum, mollissimè hirsutum, aterrimum, segmentis tribus ultimis rubris. Venter posticè rufo-pilosus.

Var. 
A PIS. (**. e. 2.)

Var. $\beta$ triplo minor; alis albo-hyalinis.

$\gamma$ procedenti dimidio minor.

Obs. In hâc varietate anus, in adultioribus, fulvo-aureus.

Maris Corpus hirsutum, subtus flavescens. Maxillce supra pallidæ, barbâ pallescenti. Antenna thorace breviores, articulis rectiusculis. Occiput et Vertex medio pilis citrinis ornata. Facies ante antennas fasciculo denso quadrangulari villorum citrinorum insignita, Truncus supra basi citrinus, medio ater, apice pallidus. Squamula picex. Ala albo-hyalinæ. Pedes rufescente-hirti, femorum barbâ dilutiori. Scopula subauratæ. Digiti ferruginei. Aldomen subovatum, ano ferrugineo.

The difference of size between $\beta$ and $\gamma$, which I take to be the two descriptions of neuters, and $\alpha$, which is the female, is so great, that were they not most exact counterparts of each other in every other respect, I should scarcely be able to persuade myself of their identity. A. pratorum of Christius, as far as I can judge from his figure, is nothing more than the largest of the two neuters of this species. The male has usually been considered as a distinct spscies: Fabricius mistook it for $A$. pratorum, Lin. but changed its name to $A$. arbustorum. That it is not $A$. pratorum, we have shewn above; it remains that we assign our reasons for giving it as the male of the species before us. In the first place Reaumur, speaking of the variations 
A PIS. (**. e. 2)

of colour observable in the cloathing of the Bombinatrices, has these words : "—dans le même nid j'ai vû naître des Bourdons de même taille, qui différoient entr'eux par le couleurs ou les distributions de couleurs dont nous venons de parler. Par exemple dans le nid peuplé de bourdons dont le derriére seul étoit feuillemorte, j’en ai vû naître quelques-uns qui avoient sur le corps une ou deux bandes transversales de couleur de citron (i)." Again, I have myself seen this insect entering the nidus of A. lapidaria, but what appears to do away all doubt upon the subject, I saw this insect in the collection of the celebrated Peter Collinson, with a memorandum affixed to it, that he had seen it connected with $A$. lapidaria.

107. A. atra, hirsuta, ano fulvo; tibiis posticis cor-Raiella. biculâ rufâ.

Bombylius minor, præcedenti concolor, abdomine imo pallidiùs rubente $f$ fulvo.

Rai. Hist. Ins. p. 246. n. 2.

MUS. D. Marsham, Latham Mas, Kirly.

Long. Corp. Lin. 6-7.

$\mathrm{Hal}$. Barhamiæ. A nobis bis atque iterum lecta; Mas semel a D. Latham.

DESCR. Acul. .

CORPUS atrum, hirsutum.

CAput. Os barbâ rufâ. Prolocis fere thoracis longitudine, palpis exterioribus petiolatis, apice lanceolatis?

(i) Ubi supr. p. 2,3.

Truncus 
Truncus ater, immaculatus. Squamula nigra: Alce subhyalinx, apice nervisque nigricantibus. Pedes atri, hirti. 'Tilice postica corbiculå rufa. Spinulce castanex. Scopulce ferrugineæ. Digiti picei, articulo extirio rubcllo.

Á Dones triangulare, hirsutum, atrum, seg: mentis tribus ultimis ferrugineo-rufrs.

Maris Caput subglobosum. Antenne thorace breviores. Ala apice immaculatæ. Pedes rufo-hirti. Anus e pallido fulvescens.

Memorice Johannis Ray t8 tave, hee Apis inscribitur.

This Apis is so similar to A. lapidaria, that, if known, it has probably been confounded with it; it differs, however, in the shape of its,exterior palpi $(k)$ and abdomen. Its corbicula is red, and its anus is paler. The accurate eye of Ray detected these differences, and he has given it as a distinct species, for his description makes it evident that he means the sime insect. "Superiore" (viz. A. lapidaria) "duplo minor est," says he, "et insigni notà $a b$ eo differt, nimirum quòd superius inter-

(k) This is a strong character, as the exterior palpi in all the aculeates, at least, of $A$. lapidaria are elongate, very slender, and filiform. I have affixed a mark of interrogation to this character, because the envelope, in which I preserve this proboscis, is latrelled A. lapidaria second magnitude. But as I formerly looked upon $A$. Raiella as a variety of that insect, and all the others have similar posterior palpi, I have little or no doubt that this proboscis belongs to the one before us.

nodium 
A PIS. (**. e. 2.)

nodium crurum posteriorum (quod compressum et latum est) ad margines fimbriâ pilorum rubentium cingitur, cùm in illo pili $\int_{\text {s }}$ setulæ internodium istud cingentes nigri sunt, reliquæ scilicet lanugini concolores." This species differs, likewise, from $A$. lapidaria in its place and mode of nidification, as we learn from the same illustrious author، "Nidifieat et mellificat in gramine eodem quo sequens (viz. A. muscorum) modo."

108. A. atra, hirsuta, ano fulvo, alis nigricantibus. rupestris,

Apis rupestris. Fab. Ent. Syst. Em. n. 26.

Apis lapidaria. Var. Brunn. Prodrom. Insectol. Sieland.p. 19. not. a a.

Apis sulterranea. Geoffr. Hist. Ins. 2. p.416, n. 20.

Fourcroy. Ent. Par. n. 21 ?

FIG. Atis subterranea. Christii Hymenopt. p. 125. tab. 6. fig. 5 ?

MUS. D. Marsham, Latham, Lathbury, Trimmer, Kirly. Long. Corp. Lin. 10-12.

Hab. In Angliâ. Prope Londinum frequens, apud nos rarissima, nec nisi unicam legi.

DESCR. Acul.

CORPUS atrum, hirsitum.

CAPUT magnum. Labium anticè obtusangu= lum $(l)$. Proboscis vix thoracis longitudine, palpis exterioribus acutis. Maxille forcipatæ, intus emarginatæ.

Truncus ater, immaculatus. Squamula magnæ, nigræ. Ala magnæ, corpore longiores,

(l) Tab. 13. fig. 12 .

nigræ, 
A PIS. (**. c. 2)

nigra, subcoriacex. Pedes atri, hirti. Tilia posticæ supra pilosæ, nec corbiculâ neque pectine instructx. Spinulce castanex. Plante posteriores absque auriculâ. Scopule ferruginex. Digiti nigri, tamen, certo situ, e tomento fulvescunt.

A B DOMEN ex ovato oblongum, atrum, utrinque hirsutum disco glabriori, segmento antepenultimo et penultimo hirsutie longiori fulvorufâ, ultimo subacuminato, tomentoso-ferrugineo. Venter segmento ultimo lateribús marginatis margine deflexo rectangulo. $\mathrm{Acu}$ leus vaginâ validá.

Obs. Omnium ferè nostratum hacc Apis maxima.

This gigantic Apis is often confounded with the female of $A$. lapidaria, and Fabricius, who has described it under the name of $A$.rupestris, seems to doubt whether it ought to be regarded as distinct: but its black wings, longer than the body, and of a substance intermediate between corium and membrane, would sufficiently establish its claim to the rank of a species, without the aid of other characters; it possesses others, however, which establish its identity beyond all doubt, for, with $A$. campestris, Barlutella, and vestalis, beforc described, it is without the instruments for preparing and carrying masses of pollen upon its posterior tibix. I an not clear that $A$. sulterranea of Christius is synonymous with it, as his figure gives a yellow band at the base of the thorax, it comes, however,

very 
very near to it. Geoffroy describes it, I think, under the same name, but neither of these is the A. subterranea of the Linnean cabinet.

109. A. atra, hirsuta, ano fusco; capite masculosulterrasubgloboso : maxillis supra tomentoso-fulvis. ${ }^{\text {nea. }}$

Apis subterranea hirsuta, atra, ano fusco.

Lin. Syst. Nat. Ed. 12. छ Gmel. p. 2783. n.51. Fn。 Suec. $n .1718$.

Fal. Ent. Syst. Em. n. 37.

Vill. Ent. Eur. 3. n. 104.

Ross. Fn. Etrusc. Mantiss, n. 315.

Miill. Zool. Dan. n. 1928.

Forst. Cat. Brit. Ins. n.730. Apis, n. 24.

FIG. Harris. Exp. Eng. Ins. tab. 38. fig. 8. Mas.

MUS. D. Smith Linnean, Fem. MTarsham, Kirly Mas.

Long. Corp. Lin. 7.

Hab. Barhamiæ. Feminam in Angliâ nondum vidi.

DESCR. $\operatorname{Mas}(m)$.

CORPUS atrum, hirsutum.

CAPU t subglobosum. Maxilla supra sericeoflavescentes, barbâ nigricanti. Antenna thoracis ferè longitudine, articulis subarcuatis.

Truncus ater, immaculatus. Squamule piceæ. Ala subcoloratæ, apice paulò obscuriores, ner-

( $m$ ) The only specimen of the other sex, that I have ever seen, is that preserved in the Linnean cabinet, I shall add the particulars in which it differs from the one I have described above as the male.

Feminæ Caput subtriangulare. Ala coloratæ nervis nigris. Scopule fuscæ. Aldomen subtriangulare, hirsutum, atrum, ano minùs nigro, $\int$. pilis fuliginosis sordidèque albidis tecto.

Long. Corp. Lin. 10.

rOL. II.

$2 \mathrm{~B}$

vis 
A PIS. (**. e. 2.)

vis piceis tenuioribus ferrugineis. Pedes atri, hirti. Spinulce castanex. Scopulce ferruginex, subauratæ. Digiti picei.

Ав DомеN subtriangulare, subacuminatum, hirsutum, atrum, ano minus nigro $\int$. fusco, qui color e pilis sordidè pallidis nigrisque mixtis exoritur.

Obs. Ani pili pallidi densiores utrinque.

This insect differs so very slightly from the specimen of the Linnean cabinet, which is an aculeate, that, I think, there can remain scarcely any doubt of its being the male of $A$. sublerranea. Linneus referred to Ray. n. 1. as synonymous with this, and adopted Geoffroy's reference, neither of which belong to the true $A$. sulterranea. Ray evidently intending by his description $A$. lapidaria, and Geoffroy $A$. rupestris, the former expressly noticing the deep red anus that distinguishes the one, and the latter the black wings which form the characteristic of the other $(n)$. Gmelin has rectified this error in some degree with respect to the synonym of Ray, by referring n. 1. to A.lapidaria, but then in its room he refers n. 2. to A. sulterranea, which we have just seen belongs to another insect $(o)$.

(n) Upon reconsidering the synonym of Geoffroy, I am not clear that it belongs to $A$. rupestris, as he says of his, "Il y a quelques poils jaunes mais peu apparens autour du col "But if it be not $A$. rupestris, it is clearly more nearly allied to it, than $A$. sulterranea.

(o) After my Synopsis Specierum was printed, upon going over 
110. A. hirsuta, aterrima.

RIG. Tub. 18. fig. 7. Acul. IVid. fig. 8. Mas. Apis retusa. Christii Hymenopt. p. 133. tal. 9. fig. 4. Mas.

MUS. D. Marsham, Haworth, Kirly.

Long. Corp. Lin. 8-10.

Hal. Barhamiæ. Mas a nobis bis atque iterum capta.

Femina semel a D. Sowerby.

\section{DESCR. Acul.}

\section{CORPUS atrum, hirsutum.}

Caput. Os et Nasus ferrugineo-barbata.

Truncus immaculatus. Squamula nigro-piceæ. Alce subcoloratæ, apice obscuriores, nervis nigricantibus. Pedes atri, hirti. Scopulce atque Digiti ferruginea.

Aвромen oblongum, totum atrum, hirsutum, ano minus nigro.

Obs. In nostro specimine al:domen anticè punctis duobus albidis insignitur. An sit hee nota constans nondum compertum hateo.

Maris Caput triangulare. Maxille supra pallidxe, barbâ rufescenti. Antennce trunco breviores, articulis subarcuatis. Aldomen ex ovato oblongum, ano obtuso. Venter nigricante hirsutulus.

I cannot help suspecting that the male of this may be the original $A$. acervorum of Linneus.

over the male Bomlinatrices, I found the maxille of all were covered with pale or tawny down, though most remarkably in this species. 
A PIS. (**. e. 2.)

It wants, indeed, the "setula quxdam circa collum sulphurex," but in other respects it agrees well with his description, for it somcwhat resembles $A$. lucorum, but it is narrower, and the terms " toto corpore nigro immaculato" exactly suit it. As another Apis, however, occupies its place in the Linnean cabinet, and the absence of the setulæ sulphurea renders its claim to it somewhat dubious, I have given it under another name. Christius has a tolerable figure of the male as $A$. retusa. It is a coincidence rather singular, that $A$. retusa should be mistaken for $A$. acervorum, and, vice versâ, $A$. acervorum for $A$. retusa. 


\title{
$(375)$
}

\section{A P P E N D I X.}

\author{
MELITTA. *. b.
}

M. ANNULATA. p. 37. add

Mas. Var. $\gamma$ antennis totis nigris; facie ante anantennas flavâ nasi suturis nigris; collare et tuberculis atris, immaculatis; tarsis obscurè rufis plantis posticis basi luteis; abdomine nitidissimo vix punctulato.

\section{* *. b.}

111. M. viridi-ænea, nitidissima; abdomine seg-Smeathmentis intermediis basi utrinque tomentoso- manella. albis.

MUS. D. Marsham, McLeay, Kirly.

Long. Corp. Lin. $3 \frac{1}{2}$.

Hal. Prope Londinum. In aggeribus nudis, apricis, uterque sexus frequens.

DESCR. Acul.

CORPUS viriaji-æneum, nitidissimum, pilis albidis subincanum.

Caput. Antennce nigræ, subtus fuscæ, basi approximata.

Truncus. Squamula ferrugineæ. Alc hyalinx, iricolores, nervis testaceis. Pedes nigri, piloso-incani, digitis rufescentibus.

$$
2 \text { в } 3
$$

Agdonen 
A в Dомгs ovale, pilosulum, segmentis apice pallidis, duobus intermediis basi utrinque tomentoso-albis. Anus villoso-pallidus.

Maris Nasus apice pallidus. Antenna thoracis longitudine, nigræ, subtus fulvac. Facies ante antennas pilis decumbentibus albicans. Ale nervis nigricantibus. Aldomen lineare, nigro-æneum, nitidissimum, segmentis margine immaculatis, intermediis basi depressiusculis, vix tomentosis.

Locus post M. aratam. p. 58 .

Memorice D. Smeathman Termitum docti Historici hece Apis consecratur.

This insect much resembles $M$. crata, but it is larger, and its abdomen is viridi-æneous. The male is half as big again as the same sex of that species, and has no white hairs at the base of the intermediate segments of the abdomen.

M. minutissima. $\mu .64$. add

Mas. Irar. $\beta$ major; antennis totis, tarsisque nigricantibus.

M. овоулта. p. 75. add

Maris Corpus pallido-pilosum. Nasus porrectus, apice maculâ luteâ. Ala paulò infuscatæ nervis nigricantibus. Tarsi sordidè lutei, Aldomen e lineari cuneiforme glaberrimun, segmentis duobus intermediis basi tomentosoalbis, pracipic utrinque. Venter planiusculus.

M. LEU - 
APPENDIX.

M. LEUCOzONIA. p. 77. add

Mas. Var. $\beta$ tarsis nigricantibus.

**. c.

M. тHORACICA. p. 101. after the synonym of Harris, add

Drury. Ins. 2. p. 70. tob.37. fig. 4.

M. NIGRO-ÆNEA. p. 110. add

There is a specimen of this Melitta in Sir J. Banks's cabinet, from the island of Madeira.

M. FULva. p. 129. after the synonym of Panzer, add

Coquebert. Ill. Ic. Ins. tab. 6. fig. 7.

M. convexiuscula.p. 166 . add

Var. $\beta$ duplo minor; thoracis pube ferrugineâ; tibiis posticis totis pallidè rufis; tarsis secundariis ferrugineis; abdomine, segmentorum marginibus exceptis, glaberrimo.

APIS. **. d. 2 . $\beta$.

A. IRICOLOR. p.310. after the synonym of Drury, add

Apis virens, Christii Hymenopt, p. 123, tal. 6. fig. 2 . 


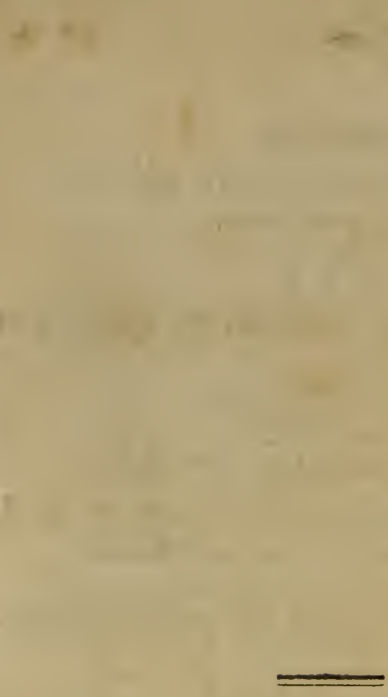

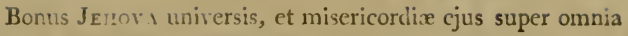
opera ejus. Celebrant te Jenova omnia opera tua.

Ps, cxlvi. 9.

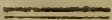




\section{( 379$)$ \\ I N D E $\mathbb{X}$.}

\section{NOMINA TRIVIALIA.}

\section{Literæ majusculæ species Linnaanas \\ - Rumanæ - Fabricii et aliorum \\ -Italicæ \\ - nunc primùm descriptas \\ \} indicant.}

Asteriscus species denotat vel sub alio nomine ab aliis descriptas, vel incertas an sint novæ.

ABBREVIATIONES.

B. valet Brunniche.

Cb. Christius.

$F$ a. Fabricius.

Fo. Forster.

- G.F. Geo.Fou. Geoffroy and Fourcroy.

G. Gmelin.

La. Latreille.

Mi. Miller. MS.
Mii. Miiller.
M. B. Mus. Banksia-
num.
M. L. Mus. Leskea-
num.
Ma. Marsham. MS.
P. Panzer.

Mi. Miller. MS.

Mii. Miiller.

num.

num.

$P$. Panzer.

\section{Pal. Pallas.}

Ro. Rossi.

Ra. Ray.

Scb. Schrank.

Sc. Scopoli.

S.R. Sulzer \& Roemer

$V$. Villers.

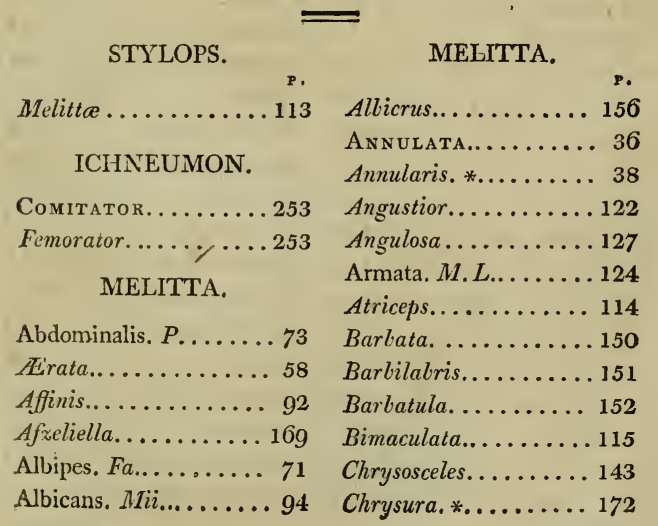

Cingulata, 


\section{MELITTA.}

Cingulata. $F a \ldots \ldots . .88$

Cineraria. ........ 98

Clarkella. *........ 130

Contigua........... 140

Coitana. ..........147

Coilinsonana. .......153

Combinata. Ch.....153

Connectens.........157

Convexiuscula.......156

Cunicularia........ 106

Denticulata......... 133

Dilatata........... 39

Divisa............. 49

Digitalis........... 159

Dorsata. .......... 144

Flavipes. Fa. . . . . 55

Fodiens. G. F....... 34

Fulvicornis.........6 67

Fulvo-cincta. *. ..... 68

Fulvago. Ch. ...... 93

Fulva. Sch........ 128

Fuscipes. ..........136

Fulvicrus........... 138

Fuscata...........167

Geoffrella. *....... 45

Gibba. Fa........ 42

Guynana. *. ....... 120

Hæmorrhoidalis. Fa. . . 141

Helvola. .........119

Lavis............. 65

Lavigata.......... 75

Lathamana......... 83

Lanifrons. ........139

Labialis. ............ 148

Leucopus...

\section{MELITTA.}

Leucozonia. Sch..... 76

Leuinella. ........149

Listerelia.......... 137

Lugulris........... 81

Malachura.......6.67

Melanocephala....... 103

Minuta. Sch. ...... 61

Minutissima. ......6 63

Minutula..........161

Monilicornis. ...... 47

Morio. Fa. ........ 60

Mouffetella.......... 108

Nana. ............161

Nitidiuscula........ 64

Nitida. G. F. . ..... 104

Nigro-anea......... 109

Nigriceps. .......... 134

Nudiuscula.......... 155

Parvula........... 162

Picea. ............ 48

Pilipes. Fa........ 96

Picicornis.......... 123

Picipes............ 127

Pilosula. ..........164

Pratensis. Mii. . .... 100

Proxima...........146

Punctulata.........6 66

Pubescens. Fa. ...... 141

Quadricincta. Fa..... 51

Quadrinotata....... 79

Rosæ. P.......... s

Rubicunda. Ch. ..... 53

Rufitarsis.......... 135

Schrankella.*...... go

Seladonia. Fa....... 57

Sexnotata! 

MELITTA.

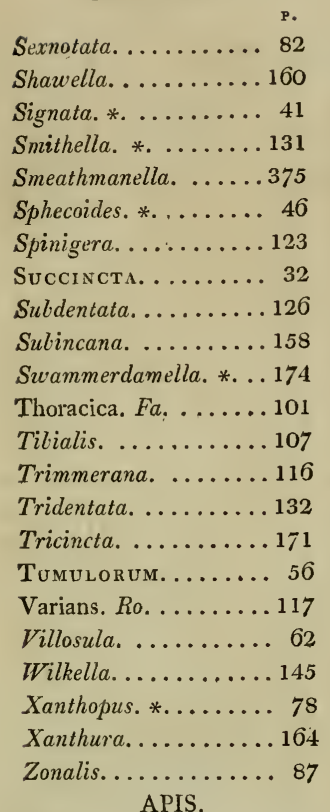

Agrorum. Fa.. . .....326

Alternata. .......... 182

Albinella. *. . . . . 361

Banksiana. ......... 179

Barbutella. *....... 343

Beckwithella. .......323

Bicornis.........2271

Bicolor. Sch.......277

Bimaculata. P. ....286

Burrellana. *........ 358

Cererulescens. .....264
APIS.

Caprece............. 193

Campanularum. *...256

Campestris. P. . . . 335

Centuncularis. . . . 237

Circumcincta. .....246

Cornigera......... 190

Connexa. *......... 199

Conica. .........224

Curtisella...........324

Cullumana.........359

Cyanea.*..........308

Derhamella. *. . . . . 363

Donovanella.........357

Druriella..........285

Fabriciella........213

Ferruginata. . . . . 2 218

Flava. $P \ldots \ldots \ldots \ldots$ s 6

Flavo-picta.........202

Flavo-guttata......215

FloRisomis. ......253

Floralis. G. ........321

Forsterella.........325

Francillonella.*..... 319

Fragrans. Pal. ......329

Francisana. . . . . . . 334

Fucata, $P$. . . . . . 195

Furcata. $P$........28s

Goodeniana.......... 180

Haworthana. .......307

Harrisella. *. . ..... 373

Hillana. .........20s

Hortorum. . . . . . . 339

Inermis. *........229

Iricolor. *.......... 310

Jacobææ. P........201

Jonella. 
APIS.

Jonella...........33s

Lathluriana. .......183

LAgOPODA........236

Latrcillilla. *. ......330

Lapidatia. ........363

Lencophthalma. . . . 197

Leuromilana. ......260

Lmiana. *..........263

Leeana.

Linncella. ........ 179

Lineola. P. . . . . . 194

Ligniseca. *. . . . . 243

Linguaria. Fa.......282

LoNGiCORNIS. . . . . 278

Lucorum. .........336

Mars/rainella. .......188

Maritima. ......... 242

Manicata. .......248

Maxillósa.......251

Meleifica: $\therefore \ldots \ldots 312$

Muscórum.........317

Ochrostoma. .......209

Palmata...........238

Pallicincta. *....... 293

Pharoptera. ........232

Pista. ............206

Pollinaris..........2s4

Pratorum............ 360

Punctata. $F a$. . . . . 219

Punctulatissima......231

Quarlrinotata........214

Raiella.*......... 367

Retusa: $\therefore \ldots \ldots \ldots 296$

Rotundata: $F a . . . \ldots 291$

Rossiella. *: $\because \ldots \ldots \ldots 331$
APIS.

Rufiventris........ 187

Rufo-picta. .......207

Ruticonnss. . . . . . 210

Ruf(i)-rincta. .......216

Rupestris. Fa. . . . . . 369

Schaffierella. *. . . 199

Scrimshirana. . . . . 342

Sexcincta. . . . . . . 198

Shepparduna. ......217

Solidaginis. P. ......204

Sowerliana. ......... 322

Soroensis. Fa....... 354

Spinulosa. .......2261

Sulcornuta.......... 192

Sulglolosa. ........293

Subinterrupta. Ma. ...356

Subterkaíe....... 371

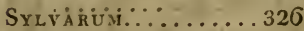

TERRESTRIS. $\because \ldots \ldots 350$

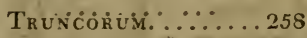

Tunènisis: Fa. .......269

Tunstallaina. *...... 346

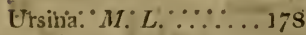

Varia. P. ....... 185

VARIEGATA. . . . . 222

Vestalis: $G$. F. . . . 347

Virgiinalis. G. F. : ...349

Vulpina. $P$........290

IVillughtiella. *. . . . 233

Xanthosticta. . . . . 212

Xanthóniclina. *. . . . 246 ,. PEDICULUS.

Melitte. ${ }_{*}: \ldots \ldots \ldots 168$ ACARUÚs.

Apum. *.: . ......277

SYNONYMA. 


\section{( 383$)$ SYNONYMA.}

SPHEX.

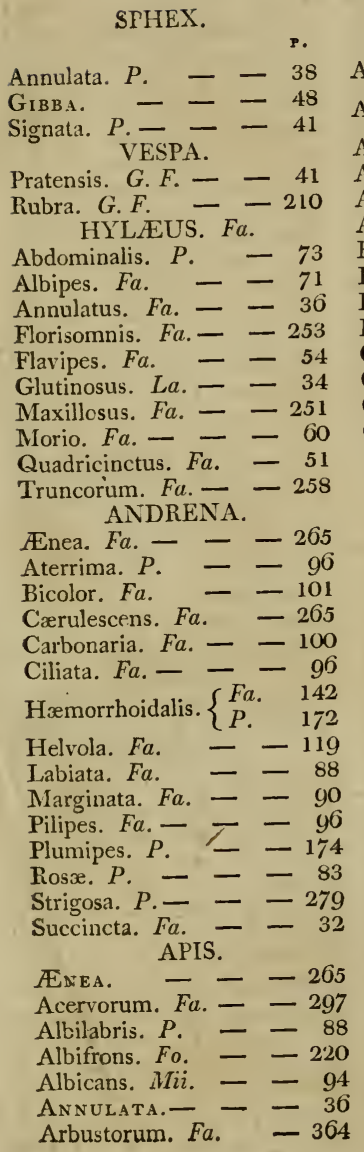

APIS.

Armata. M. L. - -124

Atra. $\left\{\begin{array}{l}\text { Sch. }- \text { - }-96 \\ \text { Sc. }-98\end{array}\right.$

Aterrima. Ch. --96

Aurea. Ma. - -128

Aurulenta. P. - -269

Autumnalis. $F a .-344$

Bicincta. Sch. - -69

Bidentata. P. - -224

Bistriata. Ch. $\quad-356$

Bryorum. Sch. - -278

Cæspitum. P. - -336

Cærulea. $V$. --308

Carbonaria. Ch. - -96

Cardui. Mii. - -355

Cetii. Sch. - - 90

$\left\{\begin{array}{l}\text { Centuncularis. } \\ \text { acuninata. }\end{array}\right\} C h . \quad 229$

Centuncularis. $P$. -243

Cerifera. Sc. --312

Cingulata. Ch. - $\quad 84$

Cineraria. - $\quad$ - 98

Cineraria. Ch. -100

Cinerea. G. F. --99

Combinata. Ch. --153

Conica. Fa. - - -229

Coronata. G.F. --365

Crocipes. G.F. --54

Cunicularia. Mi. -104

Cunicularia. - 106

Dichroa. G. $\quad-\quad 142$

Farfarisequa. P. - -174

Fabriciana. - -213

Fasciata. Sc. --321

Flavipes. $P$. $\quad-53$

$\left\{\begin{array}{l}\text { Florisomnis } \\ \text { minima. }\end{array}\right\} C h .-256$

Fronticornis. P. - -271

Frontalis. $V . \quad-272$

Frutetorum: $P .-361$

Fulvago. $C h . \quad-\quad 93$

Fulva. Sch. - -128

Fusca. 
$\Lambda$ PIS.

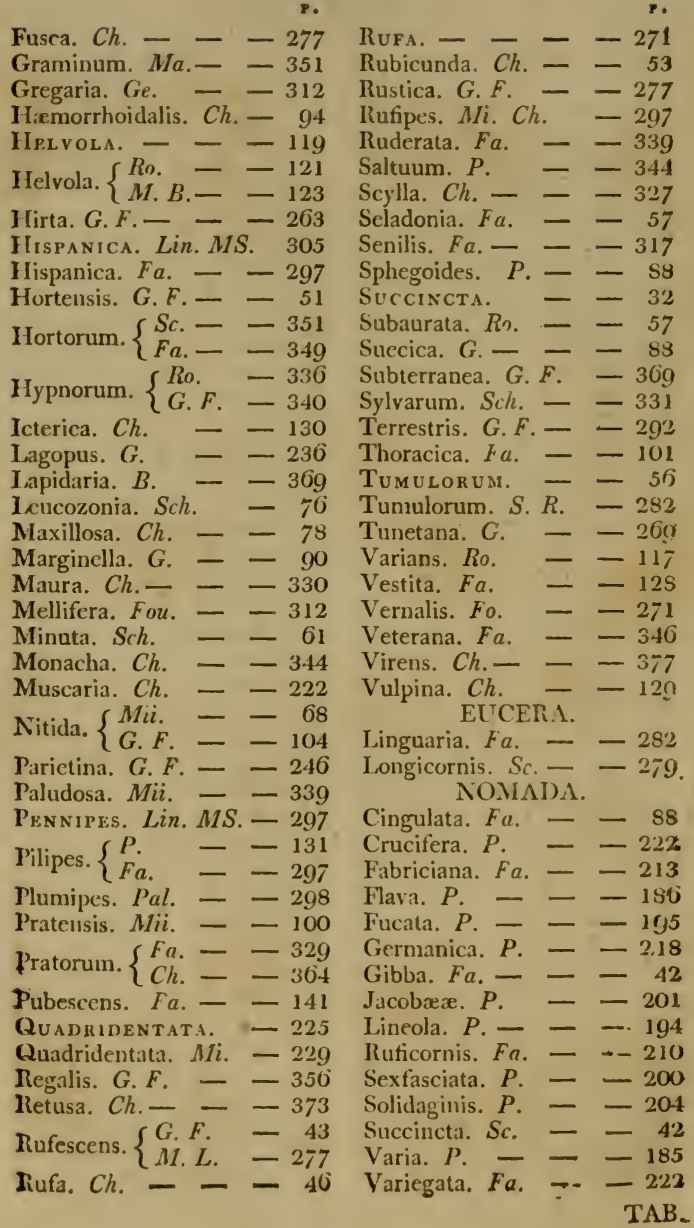




\section{IISRARY \\ CF THE}

UNIVERS TY OF RLLINOIS

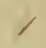



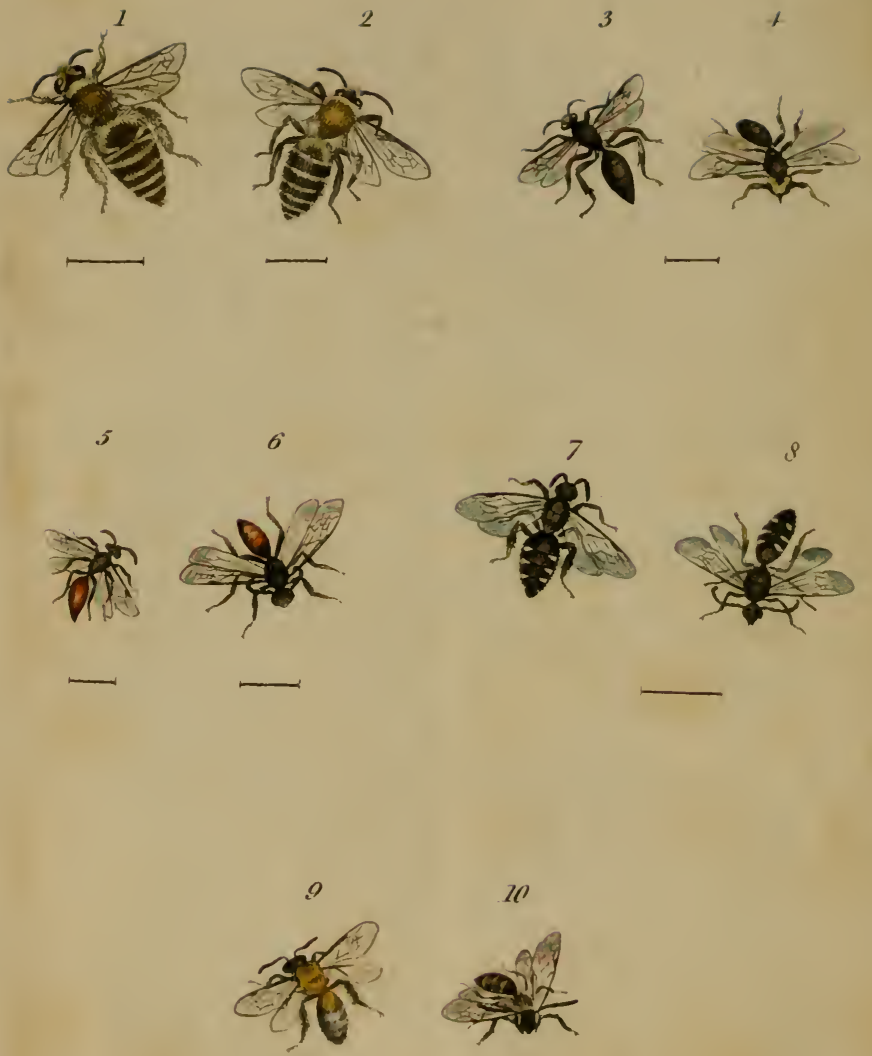
4

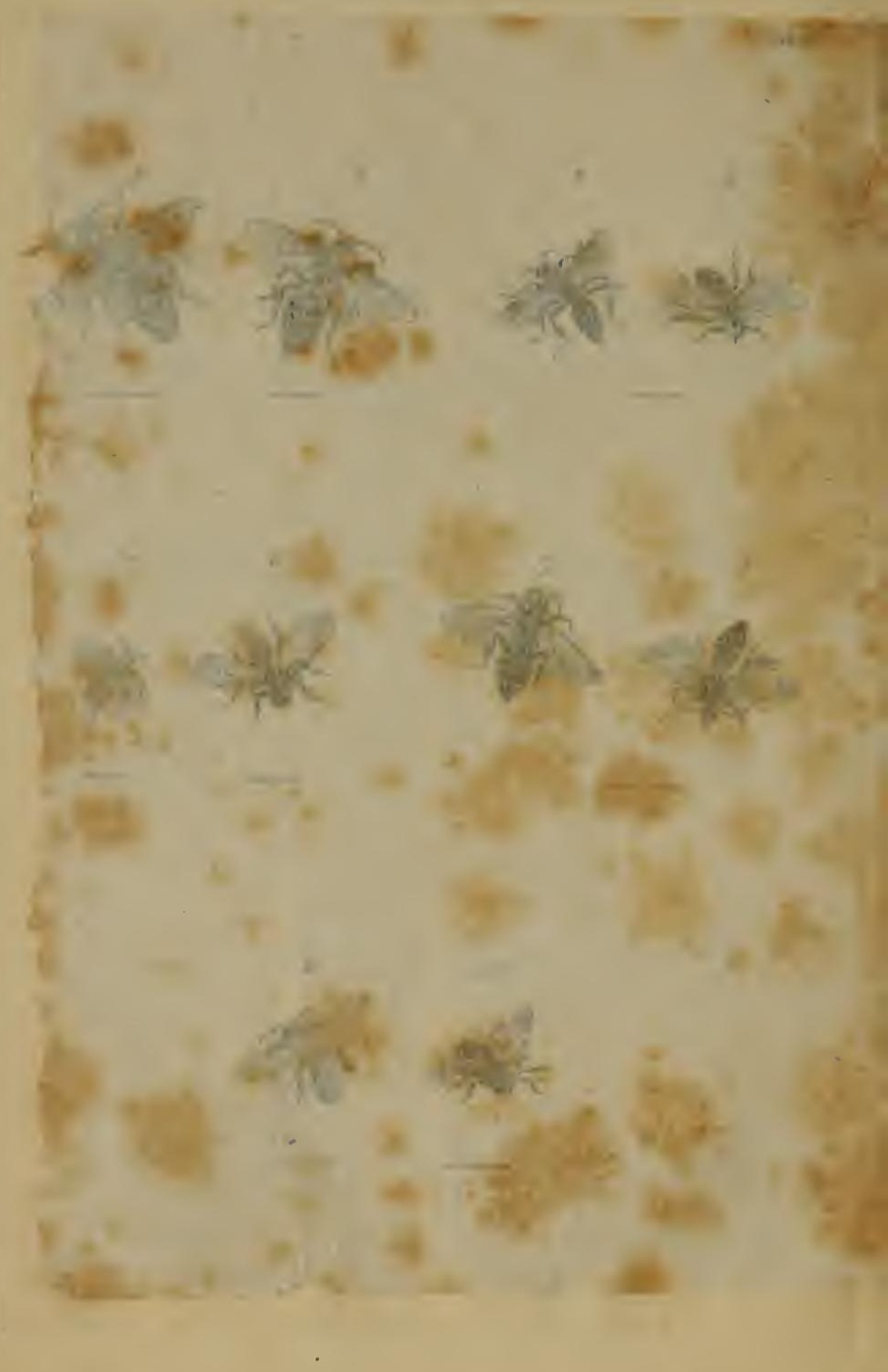




\title{
( 385$)$
}

TAB. 15.

\section{MELITTA.}

\author{
*. a.
}

FIG. 1. M. fodiens. fem.

2. Ditto. mas.

$$
\text { . *. b. }
$$

3. M. annulatà. fem.

4. M. dilatata. mas.

$$
\text { **. a. }
$$

5. M. Geoffrella. fem.

6. M. monilicornis. mas 6 .

$$
\text { **. b. }
$$

7. M. sexnotata. fem.

8. Ditto. mas.

$$
\text { **. c. }
$$

9. M. helrola. $\mathrm{fem}$.

10. M. spinigera. mas. 


\section{( 386 )}

\section{TAB. 16 .}

APIS.

*. a.

FIG. 1. A. ursina. fem.

2. A. Linnæella. mas.

*. b.

3. A. Fabriciella. fem.

4. A. ferruginata. mas.

**. a.

5. A. punctata. mas.

$$
\text { **. b. }
$$

6. A. variegata. fem.

* *. c. 1. $a$.

7. A. conica. fem. $\beta$.

8. A. inermis. mas.

**. c. 1. $\beta$.

9. A. punctulatissima. fem.

* *. c. 2 . $\alpha$.

10 A. circumcincta. fem.

11. A. ligniseca. mas.

**. c. 2 . $\beta$.

12. A. manicata. fem.

13. Ditto. mas.

* *. c. 2 . $\gamma$.

14. A. Campanularum. fem.

15. Ditto. mas. 


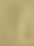

10.

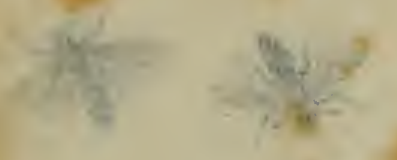
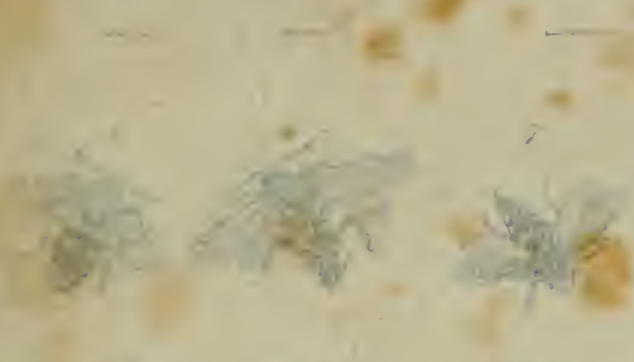

$\operatorname{Tab} 16$
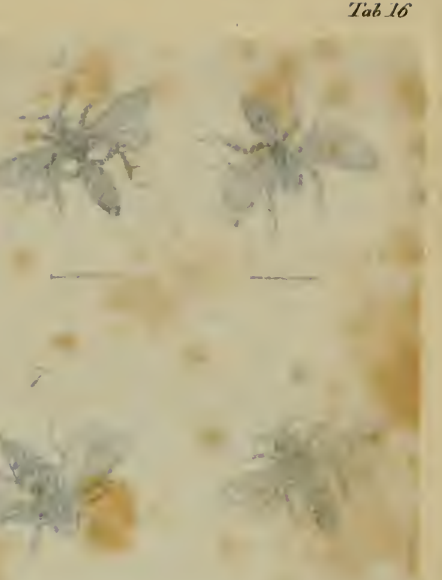

4

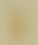

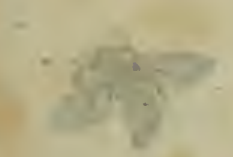

$\sqrt{2}+x^{2}$

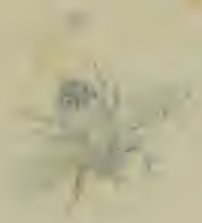<smiles>CCC</smiles>

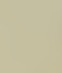

n (1) 


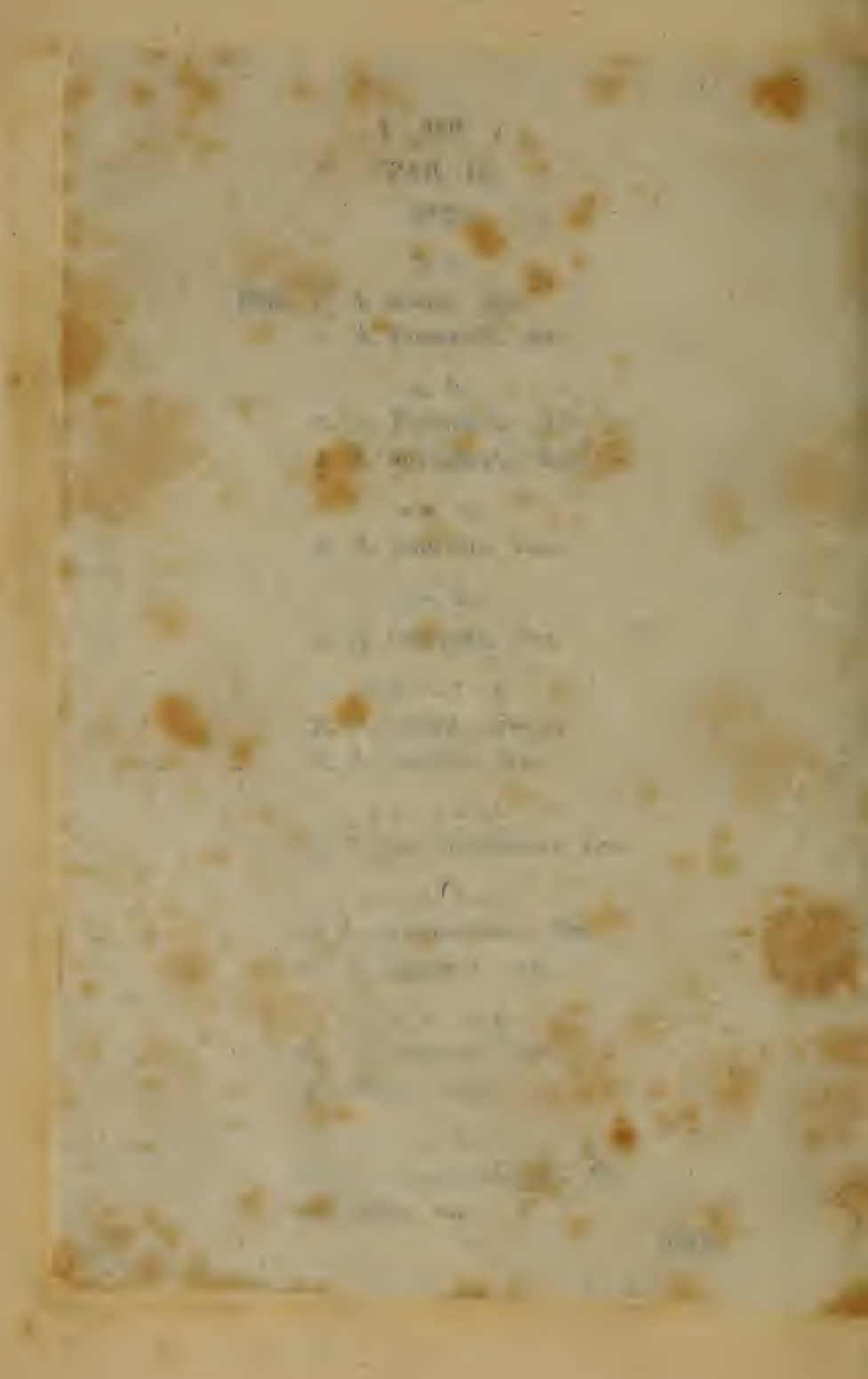



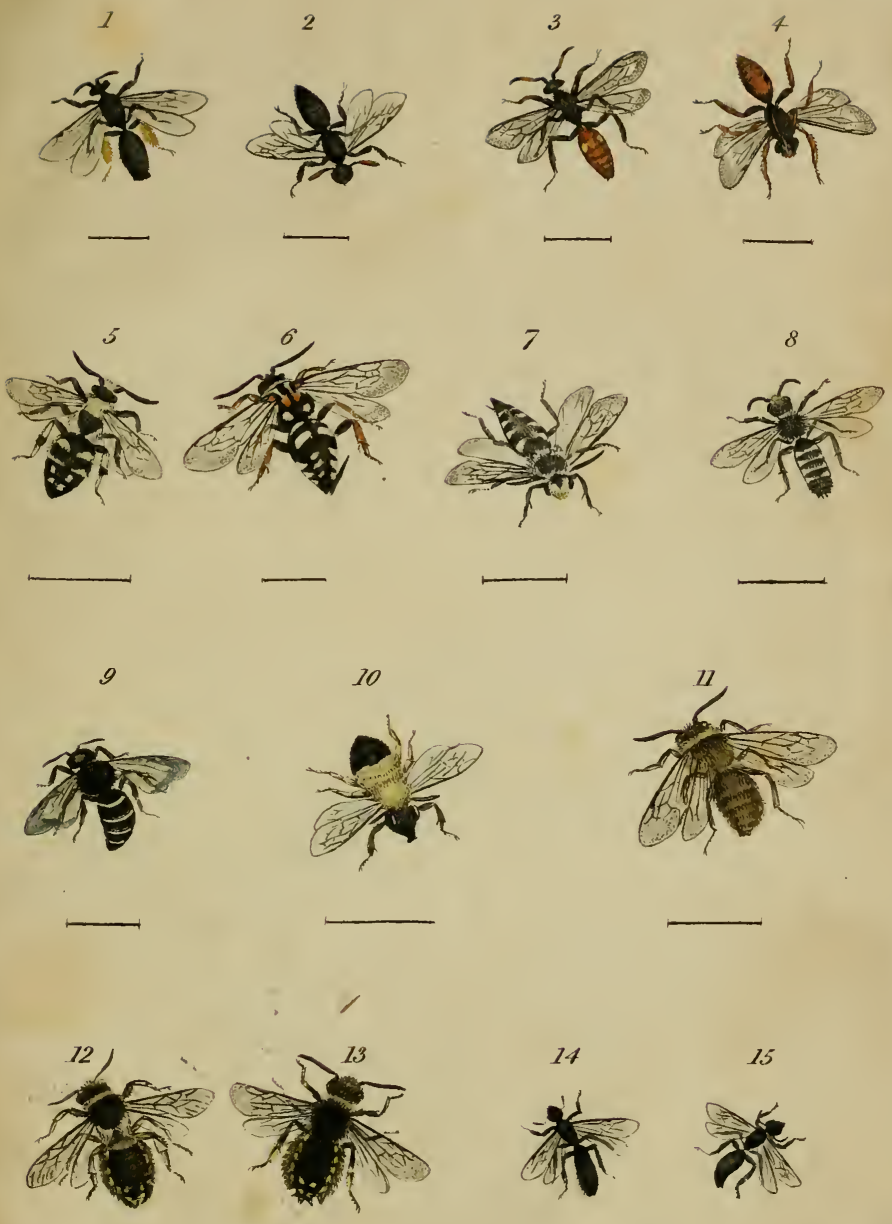


\section{LIBTAARY \\ of TIF. \\ UNIVERSITY OF ILLINOIS}




\section{LIBRARY \\ CF THE \\ UNIVERSITY OF ILLINOIS}


Tah17
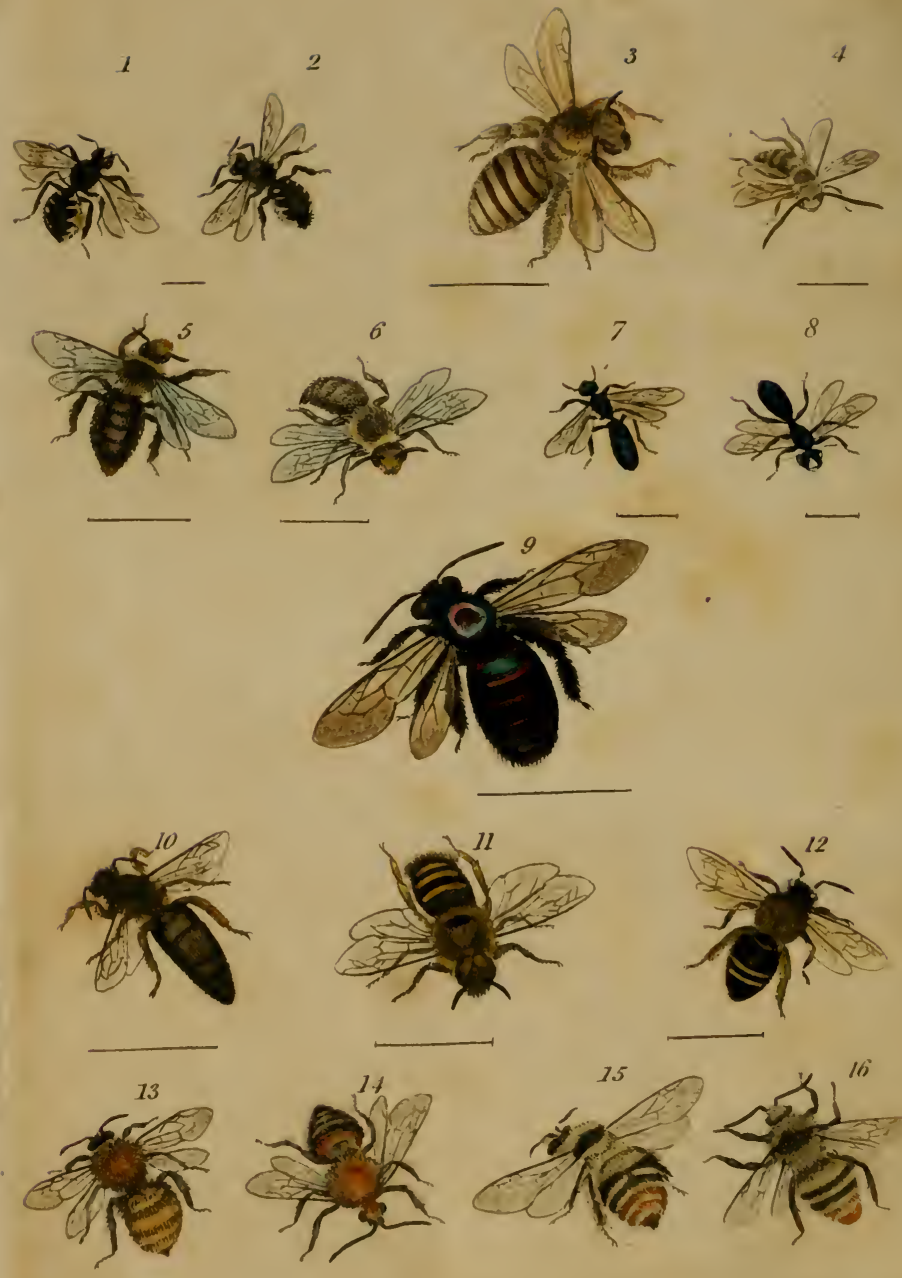


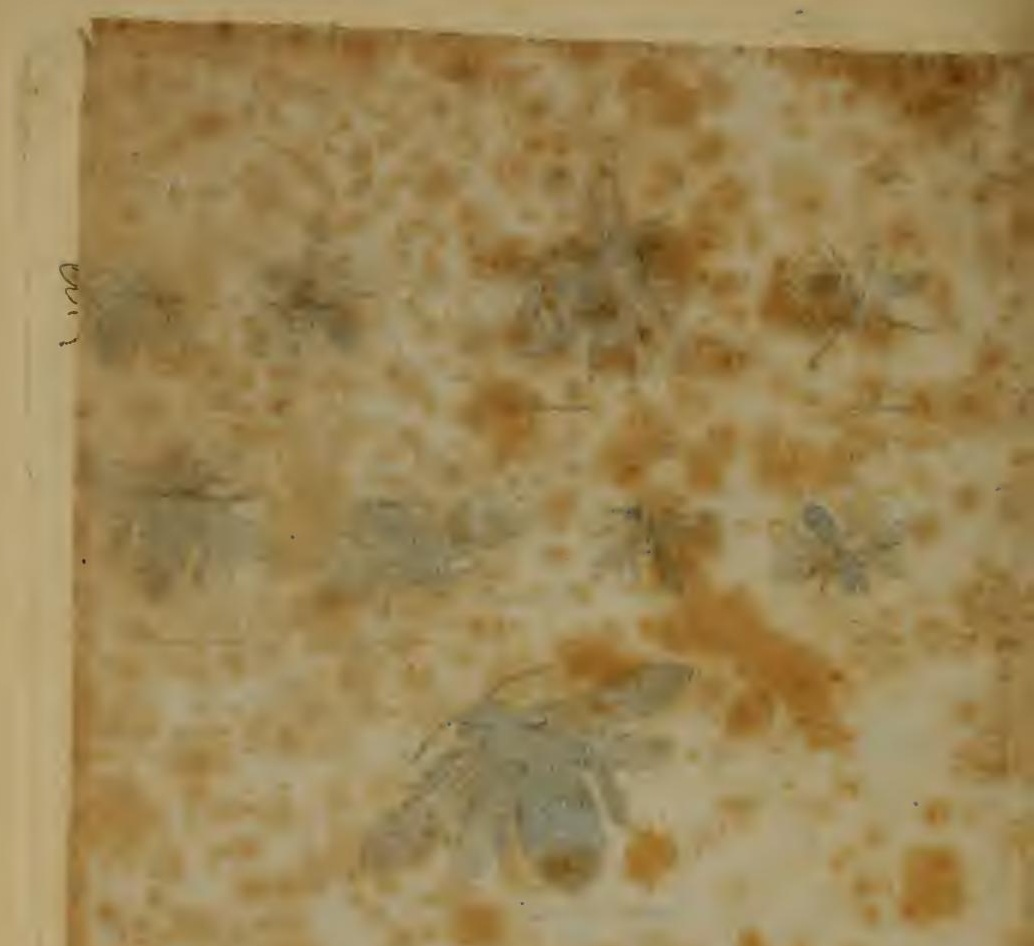

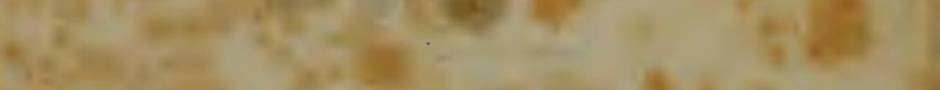

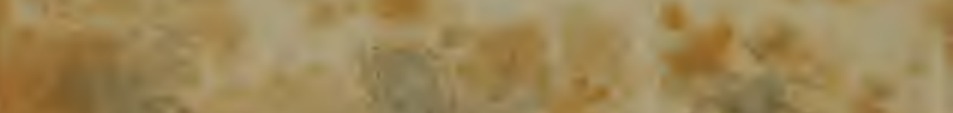

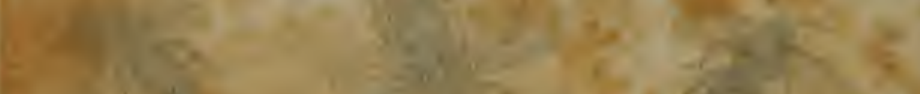

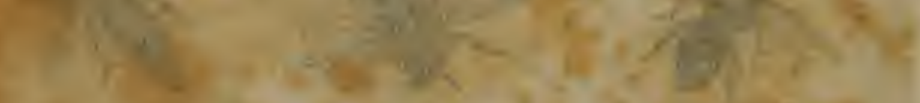

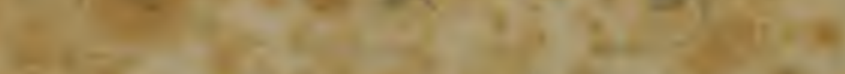

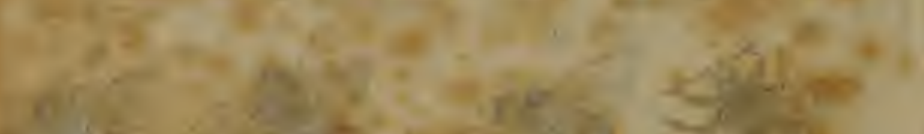

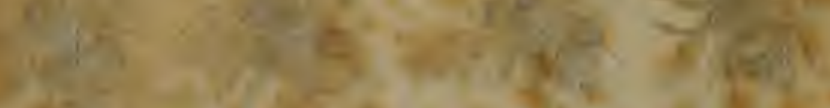

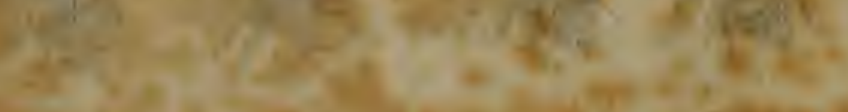
- 


\section{( 387$)$}

TAB. 17 .

\section{APIS.}

**. c. 2 . $\delta$.

FIG. 1. A. spinulosa. fem.

2. Ditto. mas.

$$
\text { **. d. } 1 \text { : }
$$

3. A. pollinaris: fem.

4. A. Druriella, mas.

* * d. $2 . \alpha$.

5. A. furcata. fem.

6. Ditto. mas.

7. A. cyanea. fem.

8. Ditto. mas.

**. d. 2 . $\beta$.

9. A. iricolor. fem.

**. e. 1 .

10. A. mellifica. fem.

11. Ditto. mas.

12. Ditto. operar.

**. e. 2 .

13. A. Francillonella. fem.

14. A. floralis. mas.

15. A. sylvarum. fem.

16. Ditto. mas. 


\title{
( 388$)$
}

\author{
TAB. 18.
}

\section{APIS.}

**. e. 2. cont.

\section{FIG. 1. A. Rossiella. mas.}

2. A. campestris. fem.

3. A. vestalis. fem.

4. Ditto. mas.

5. A. subinterrupta. fem.

6. A. Donovanella. mas.

7. A. Harrisella. fem.

8. Ditto. mas.

\section{FIN IS.}

$\overline{\text { J. Raw, Prinler, Ipswich. }}$ 


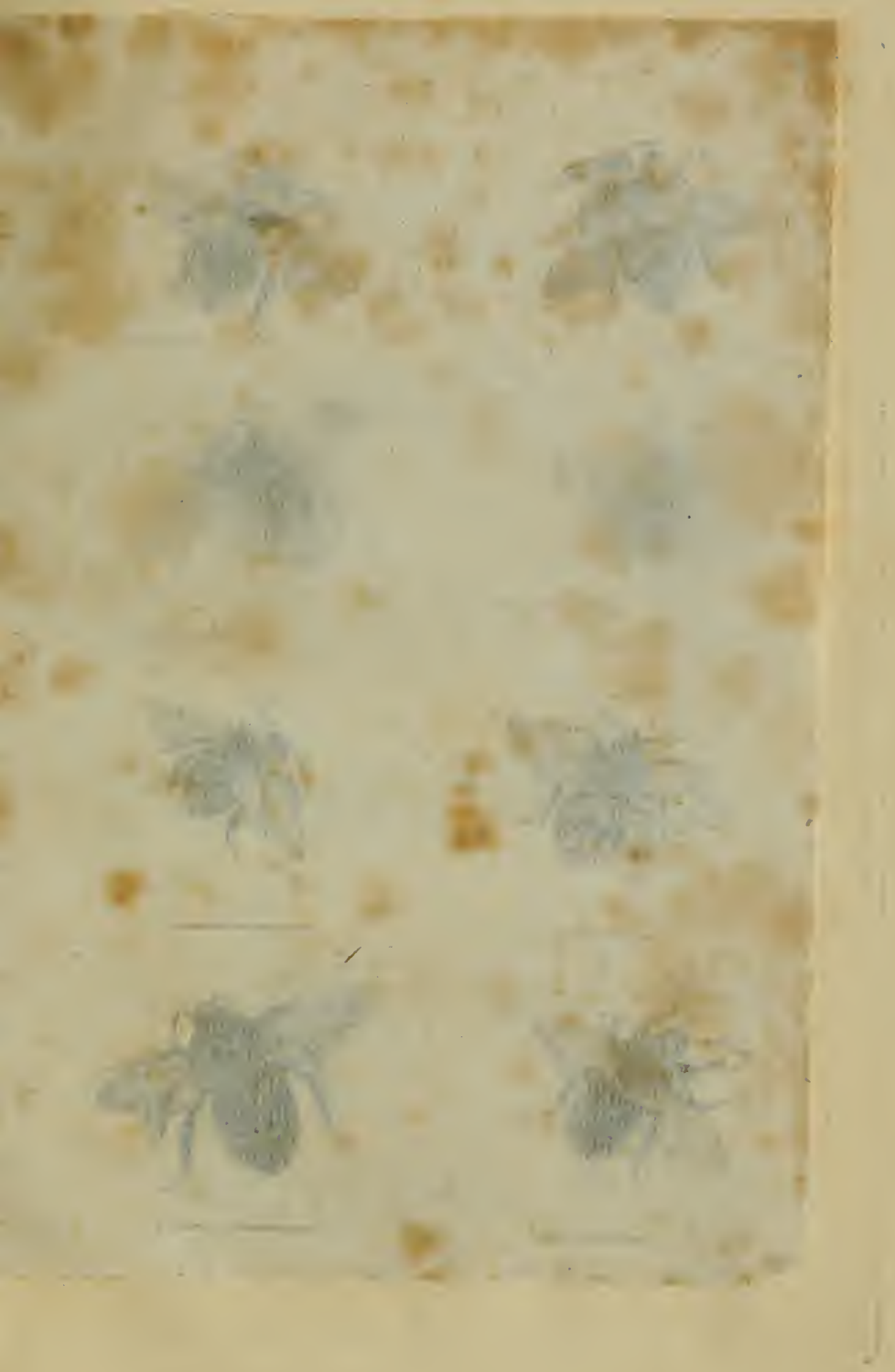



Tub.18
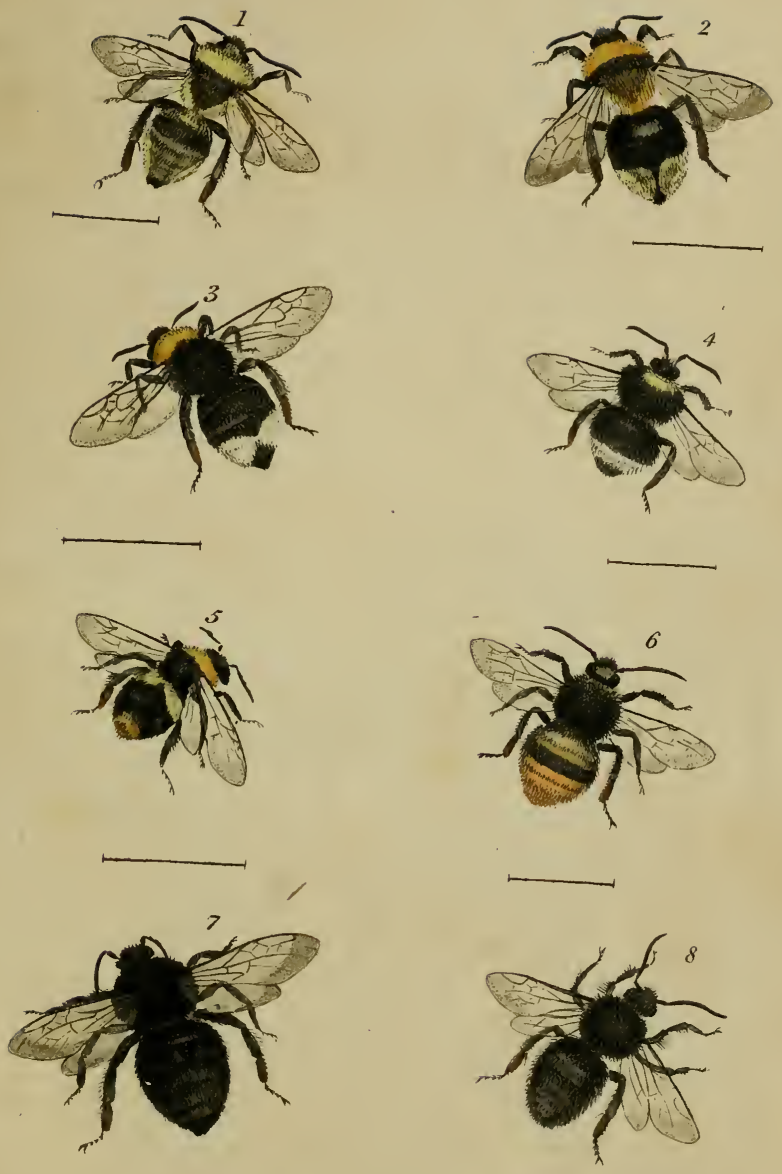
UNIVESTITY OF ILLIROIS 

